\title{
An Application of the Delphi Method of Forecasting to the Future of Public Education in West Virginia
}

Carl H. Friebel Jr.

West Virginia University

Follow this and additional works at: https://researchrepository.wvu.edu/etd

Part of the Educational Leadership Commons

\section{Recommended Citation}

Friebel, Carl H. Jr., "An Application of the Delphi Method of Forecasting to the Future of Public Education in West Virginia" (1999). Graduate Theses, Dissertations, and Problem Reports. 7487.

https://researchrepository.wvu.edu/etd/7487

This Dissertation is protected by copyright and/or related rights. It has been brought to you by the The Research Repository @ WVU with permission from the rights-holder(s). You are free to use this Dissertation in any way that is permitted by the copyright and related rights legislation that applies to your use. For other uses you must obtain permission from the rights-holder(s) directly, unless additional rights are indicated by a Creative Commons license in the record and/ or on the work itself. This Dissertation has been accepted for inclusion in WVU Graduate Theses, Dissertations, and Problem Reports collection by an authorized administrator of The Research Repository @ WVU.

For more information, please contact researchrepository@mail.wvu.edu. 
An Application of the Delphi Method of Forecasting to the Future of Public Education in West Virginia

Carl H. Friebel, Jr., M.A.

Dissertation submitted to the College of Human Resources and Education at West Virginia University in partial fulfillment of the requirements for the degree of

Doctor of Education

in

Educational Leadership Studies

Phyllis C. Durden, Ed.D., Chair

Sharon Z. Brisbin, Ed.D.

Ernest R. Goeres, Ph.D.

Perry D. Phillips, Ed.D.

Floyd L. Stead, Ed.D.

Department of Advanced Educational Studies

Morgantown, West Virginia

1999

Keywords: Delphi, Forecasting, Future Studies, Public Education, West Virginia Copyright 1999 Carl H. Friebel, Jr. 


\author{
ABSTRACT \\ An Application of the Delphi Method of Forecasting \\ to the Future of Public Education in West Virginia \\ Carl H. Friebel, Jr., M.A.
}

This study investigated the nature and types of events that will affect the future of public education in West Virginia. A three round modified Delphi design was used to identify the events, estimate when each might occur, and determine their level of impact and desirability.

In Round 1, surveys were mailed to forty-seven educational leaders representing various educational agencies and constituencies in West Virginia. In response to the first survey, panelists generated a total of one hundred thirty-four events which had at least a 50 percent probability of occurrence between the present and the year 2020. In Round 2, panelists were asked to predict the time frame of occurrence, and the level of impact and desirability for each event generated in Round 1. Round 3 results identified a total of forty-seven events which 80 percent of the panel members indicated would occur.

The total return of surveys was 89.4 percent in Round 1, 91.5 percent in Round 2, and 89.4 percent in Round 3. A total of 83.0 percent of the panelists participated in all three rounds of the Delphi.

A scenario was constructed based on the time frames of the events. Time frames were organized according to topical areas including Students, Personnel, Curriculum, Governance, Finance, Facilities, School-Community Relations, Technology and Miscellaneous. Levels of impact and desirability for each event were identified within each topical area.

Seven long term trends were identified which should be of significant importance to 
educators and educational planners. Among these trends are that (1) accountability and expectations for student achievement and behavior will increase; (2) schools will play an increasing role in the resolution of the problems of society; (3) a projected teacher shortage will affect changes in funding and staffing patterns; (4) public education will experience increasing competition from the private sector; (5) technology will play an increasing role in the education process; (6) new systems of financing public education will be developed, and (7) there will be continued emphasis on improving and replacing school facilities throughout West Virginia. 


\section{DEDICATION}

This work is dedicated to the memory of my beloved son, Casey. Through God's

promise, I will see him again someday. 


\section{ACKNOWLEDGMENTS}

Completion of this project resulted from the cooperation of many individuals to whom I am deeply grateful and indebted. First and foremost, my wife, Rita, sacrificed so much as I pursued this goal. I hope that in time I will be able to repay what she so willingly gave.

The members of my dissertation committee were always available to provide assistance and support. Dr. Phyllis C. Durden chaired my committee as well as the CEO Cohort II at West Virginia University. She gave so much to me and all of my colleagues for which she has my utmost gratitude and respect. Dr. Floyd L. Stead, who introduced me to the Delphi method of forecasting, guided the research component of this study. Dr. Ernest R. Goeres was a constant source of encouragement and was always available to offer suggestions which enhanced this study. Dr. Perry D. Phillips not only supported my project, but provided advice throughout my

Cohort experience. Dr. Sharon Z. Brisbin, my colleague and friend, shared ideas on refinements which improved my study.

My thanks are also extended to the members of CEO Cohort II at West Virginia University - Butch, Bill, Donna, Teddi, Toni, Jeff, Lyn, Anne, Ron, Howard, Judy, David and Ray. From them I learned so much. I only hope that they also learned something from me.

I am indebted to the 47 members of my expert panel for their willingness to assist with this project. Their schedules are very busy, but most took time to complete all rounds of the study. Appreciation is also expressed to Robert E. Kittle, superintendent of the Harrison County 
Schools, for facilitating my participation in the Cohort. Mr. Kittle always offered encouragement and support.

Special thanks are extended to Pauline G. LeRoy - my editor, my colleague, and most especially, my friend. Polly's mastery of the written word was such a valuable help, and she gave unselfishly of her time so that I could meet my deadlines.

Love and appreciation are expressed to my parents, Carl and Evelyn Friebel, who gave me the foundation necessary to achieve this goal. I hope they are as proud of me as I am of them. 


\section{TABLE OF CONTENTS}

LIST OF TABLES $\ldots \ldots \ldots \ldots \ldots \ldots \ldots \ldots \ldots \ldots \ldots \ldots \ldots \ldots \ldots \ldots$

CHAPTER 1

INTRODUCTION $\ldots \ldots \ldots \ldots \ldots \ldots \ldots \ldots \ldots \ldots \ldots \ldots \ldots \ldots \ldots \ldots$

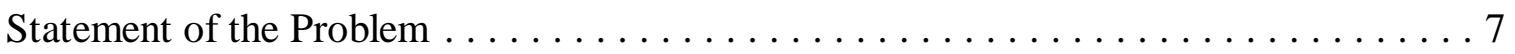

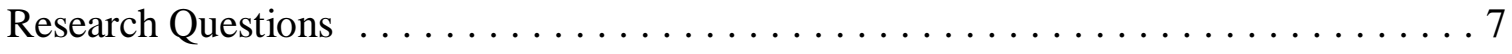

Significance of the Study $\ldots \ldots \ldots \ldots \ldots \ldots \ldots \ldots \ldots \ldots \ldots \ldots$

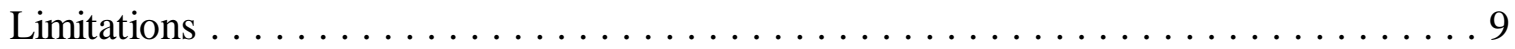

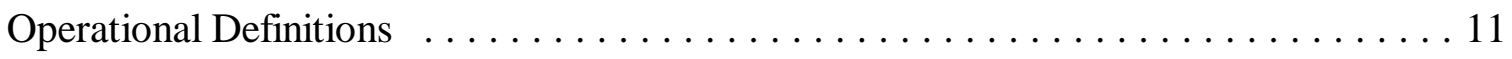

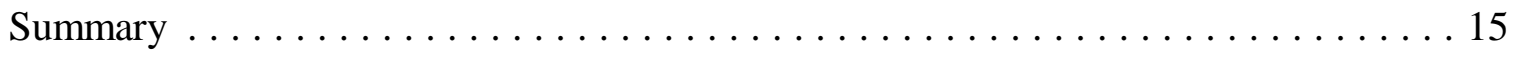

CHAPTER 2

REVIEW OF LITERATURE $\ldots \ldots \ldots \ldots \ldots \ldots \ldots \ldots \ldots \ldots \ldots \ldots \ldots \ldots \ldots$

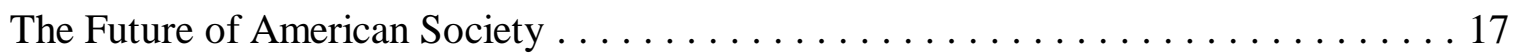

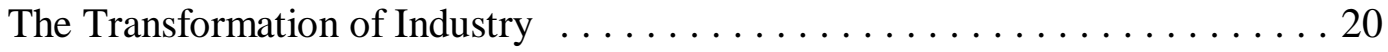

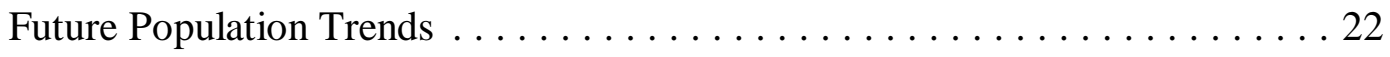

America in Decline .............................. 25

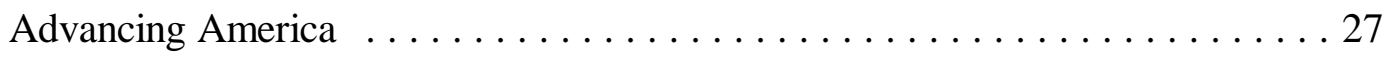

The Rise in Skepticism . . . . . . . . . . . . . . . 28

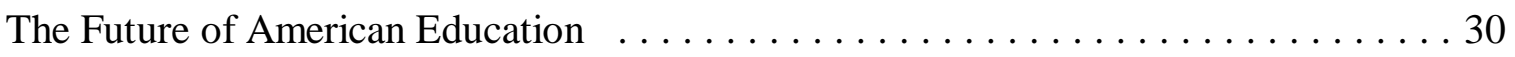

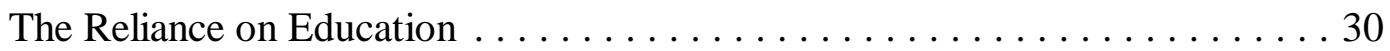




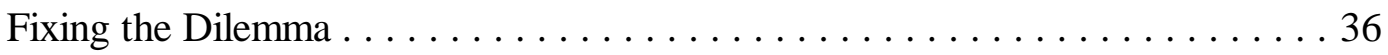

The Move Toward National Standards . . . . . . . . . . . . . . . . 39

The Politicization of Public Education $\ldots \ldots \ldots \ldots \ldots \ldots \ldots \ldots \ldots$

Social Problems and the Schools ...................... 52

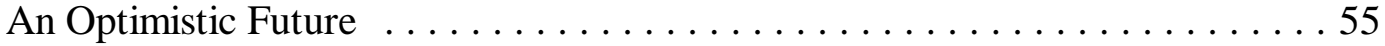

The Role of Government $\ldots \ldots \ldots \ldots \ldots \ldots \ldots \ldots \ldots \ldots \ldots$

Problems Created By Society . . . . . . . . . . . . . . . . . . 57

Outside Competition . . . . . . . . . . . . . . . . . . . . 62

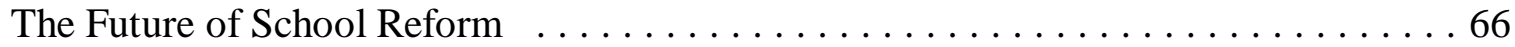

Reform Under Clinton $\ldots \ldots \ldots \ldots \ldots \ldots \ldots \ldots \ldots \ldots \ldots$

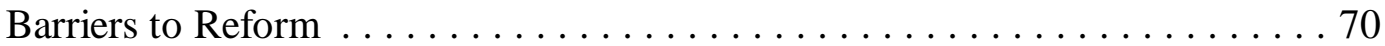

The Failure of School Reform . . . . . . . . . . . . . . . . . 72

The Continued Need To Reform ......................... 73

School Reform in West Virginia ............................. 73

Demographics Changes and the Educational Environment $\ldots \ldots \ldots \ldots .75$

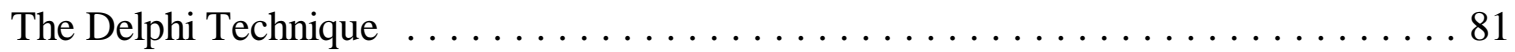

Delphi Studies in Education $\ldots \ldots \ldots \ldots \ldots \ldots \ldots \ldots \ldots \ldots \ldots \ldots \ldots \ldots \ldots \ldots$

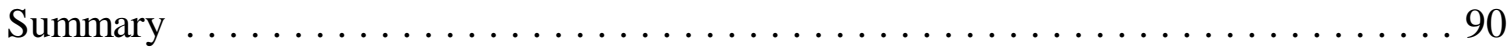

CHAPTER 3

METHODOLOGY ....................................... 97

Sample ...........................................97

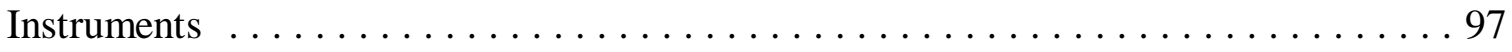

viii 
Design ....................................... 99

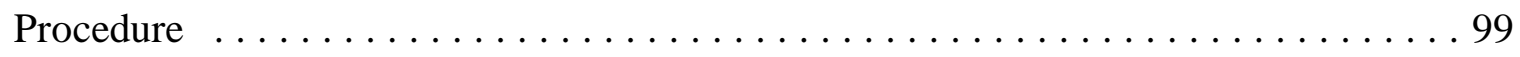

Data Analysis . . . . . . . . . . . . . . . . . . . . . . . . 102

CHAPTER 4

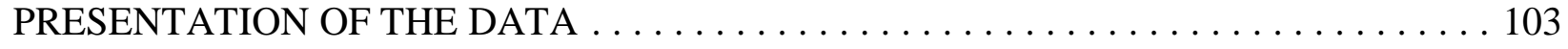

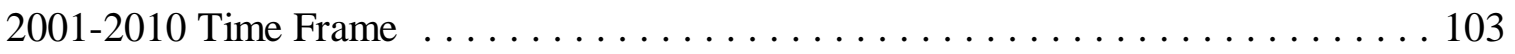

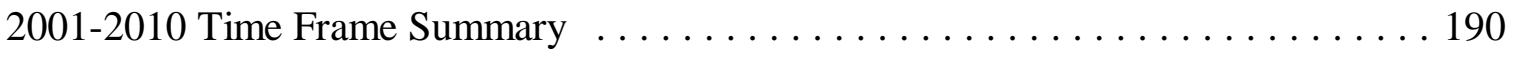

2011-2020 Time Frame ................................. 191

2011-2020 Time Frame Summary $\ldots \ldots \ldots \ldots \ldots \ldots \ldots \ldots \ldots \ldots \ldots \ldots \ldots$

After 2020 Time Frame ............................... 237

After 2020 Time Frame Summary . . . . . . . . . . . . . . . . . . . . . . . 244

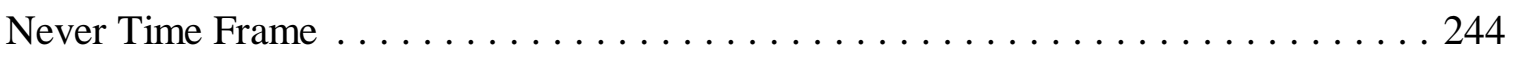

Never Time Frame Summary $\ldots \ldots \ldots \ldots \ldots \ldots \ldots \ldots \ldots \ldots \ldots \ldots \ldots \ldots$

CHAPTER 5

SCENARIO, SUMMARY, CONCLUSIONS AND RECOMMENDATIONS . . . . . . . . . 259

Scenario ............................................. 259

Intermediate-Term Time Frame - 2001-2010 . . . . . . . . . . . . 260

Long-Term Time Frame $-2011-2020 \ldots \ldots \ldots \ldots \ldots \ldots \ldots \ldots \ldots$

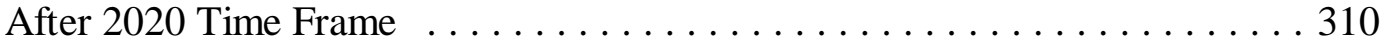

Never Time Frame $\ldots \ldots \ldots \ldots \ldots \ldots \ldots \ldots \ldots \ldots \ldots \ldots \ldots \ldots \ldots \ldots \ldots$

Scenario Summary ............................... 315

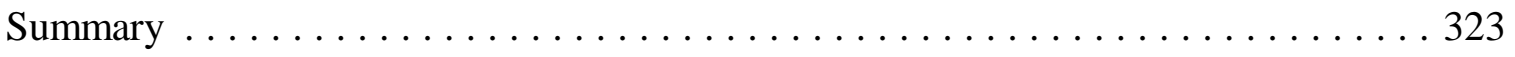

Collection of the Data ............................ 323 


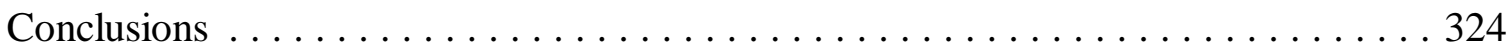

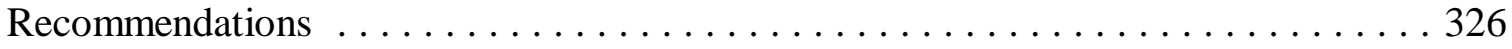

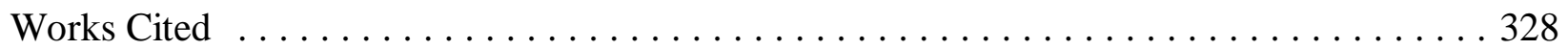

Appendices

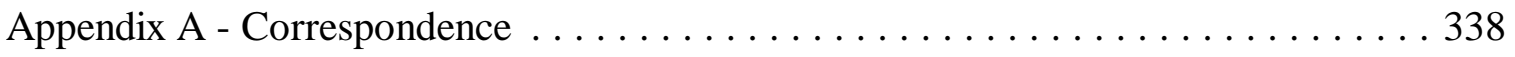

Appendix B - Survey Instruments . . . . . . . . . . . . . . . . . . . . 344

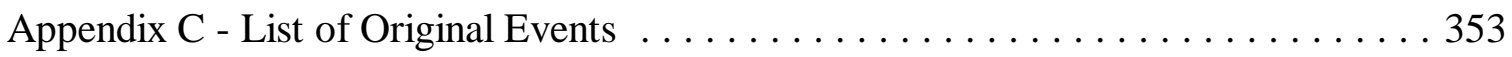

Appendix D - List of Events by Time Frame . . . . . . . . . . . . . . 362

Appendix E - List of Primary and Secondary Events by Time Frame, Impact,

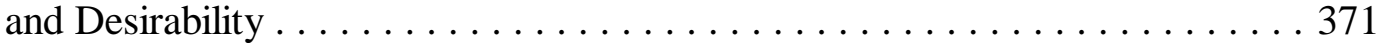

Appendix F - Rank Order of Mean Impact and Desirability Ratings of Events . . . . . 380

Appendix G - Vita . . . . . . . . . . . . . . 387 


\section{LIST OF TABLES}

Table 1

Rank Order of Mean Impact and Desirability Ratings of Events

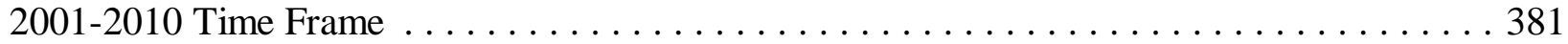

Table 2

Rank Order of Mean Impact and Desirability Ratings of Events

2011-2020 Time Frame . . . . . . . . . . . . . . . . . . . . . . . . . . . . . . . . . 384

Table 3

Rank Order of Mean Impact and Desirability Ratings of Events

After 2020 Time Frame . . . . . . . . . . . . . . . . . . . . . . . . . . 385

Table 4

Rank Order of Mean Impact and Desirability Ratings of Events

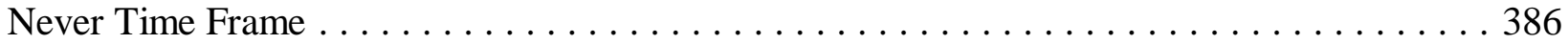




\section{CHAPTER 1}

\section{Introduction}

Education, like other aspects of American culture, exists in a constant state of change.

As society has changed, the role of public education has expanded with schools now expected to address a wide range of problems including drug abuse, teenage pregnancy, child abuse, low achievement, discipline, violence and safety, school dropouts, discrimination, sexual harassment, one parent homes, and latchkey children. Schools must also deal with the internal problems of inadequate budgets, deteriorating school buildings, a shortage of high-quality teachers, and overcrowded classrooms. "Society expects the schools to educate students in more areas, resolve more problems, and yet maintain the high standards that existed in the past or at least in memories

of the past."1

Changes in the educational environment seem to indicate that: (1) educators face increasingly complex ethical decisions, (2) there is increasing concern about the quality of educational output (i.e., accountability, assessment), (3) teachers are being increasingly at-risk in terms of school violence and criticism by parents and the public, (4) there is increasing emphasis on cost effectiveness or cost per student as school budgets are strained, (5) educators must address multicultural needs and values, and (6) school districts need to hire and retain high quality

\footnotetext{
${ }^{1}$ Bacal, Eva K. 1987. “On Being A School Board Member.” American School Boards: The Positive Power. Arlington: National School Boards Association, p. 11.
} 
personnel. $^{2}$

Most often, the response from the educational community is reactionary to events that have already taken place. While public education attempts to deal with some of the current problems of American society, educational leaders are expected to be visionary in their attempts to find solutions.

The first basic ingredient of leadership is a guiding vision. The leader has a clear idea of what he wants to do - professionally and personally - and the strength to persist in the face of setbacks, even failures. Unless you know where you're going, and why, you cannot possibly get there. ${ }^{3}$

Developing a vision for the future and deciding how an organization will look and function in that future are essential ingredients of planning for organizational success. ${ }^{4}$ In order to be effective, school leaders must have some idea or perception about what the future might be like, and have the ability to interpret their ideas and perception into actions.

Not only do we demand that leaders be credible, we also demand that they be forward-thinking: that they have a sense of direction and a vision for the future. This capacity to paint an uplifting and ennobling picture of the future is, in fact, what differentiates leaders from other credible sources. ${ }^{5}$

"Selecting a future and pursuing it with all the energy, wisdom, and resources at one's

\footnotetext{
${ }^{2}$ Slaten, Jonathan R., et. al. 1994. “A Comparison of School Board Members' and Superintendents' Ethical Reasoning Processes." Paper presented at the Annual Meeting of the Southwest Educational Research Association, San Antonio, TX, (January 27-29), p. 19.

${ }^{3}$ Bennis, Warren. 1989. On Becoming A Leader. Reading, MA: Addison Weseley, pp. 39-40.

${ }^{4}$ Romney, Valerie A. 1996. Strategic Planning and Needs Assessment for Schools and Communities. Fairfax, VA: National Community Education Association, pp. 25-26.

${ }^{5}$ Kouzes, James M., and Barry Z. Posner. 1996. "Seven Lessons for Leading the Voyage to the Future" in The Leader of the Future, by Frances Hesselbein, Marshall Goldsmith and Richard Beckhard. San Francisco: Jossey-Bass, p. 103.
} 
command require strategic thinking in the long run and purposeful action in the short run."6

Visions for the future also must be based in reality. "The first responsibility of a leader is to define reality."7 Definitions of reality are based on individual gender and cultural background. In defining the reality of the future, "the task is to forge a shared vision." "Leaders who can spark the imagination with a compelling vision of a worthwhile end that stretches us beyond what is known today, and who can translate that to clear objectives, are the ones we follow.",

If leaders are to be effective, a keen perception of the future must be in place. Charles F. Kettering stated, "We should all be interested in the future because we will have to spend the rest of our lives there."10 "The search for a more successful tomorrow is the quest of most humans, and the need to anticipate and manage a brighter future is a universal need."11

No one knows, of course, how or by what public education will be affected next year or in the next decade; we're certain only that something will come along that will be as significant as the challenges faced by public schools in the past - from consolidation to Sputnik to the new pressure and calls for reform. ${ }^{12}$

\footnotetext{
${ }^{6}$ Schlechty, Phillip C. 1990. Schools for the Twenty-first Century, Leadership Initiatives for Educational Reform. San Francisco: Jossey-Bass, p. 138.

${ }^{7}$ DePree, Max. 1989. Leadership is an Art. New York: Dell, p. 11.

${ }^{8}$ Melendez, Sarah E. 1996. “An “Outsider's" View of Leadership” in The Leader of the Future, by Frances Hesselbein, Marshall Goldsmith and Richard Beckhard. San Francisco: Jossey-Bass, p. 296.

${ }^{9}$ DeCrane, Alfred C., Jr. 1996. “A Constitutional Model of Leadership,” in The Leader of the Future, by Frances Hesselbein, Marshall Goldsmith and Richard Beckhard. San Francisco: Jossey-Bass, p. 252.

${ }^{10}$ Kuriam, George Thomas, and Graham T. Moliter, eds. 1996. Encyclopedia of the Future. New York: Simon and Schuster McMillan, p. vii. p. 17.

${ }^{11}$ Hoyle, John R. 1995. Leadership and Futuring, Making Visions Happen. Thousand Oaks: Corwin Press,

${ }^{12}$ National School Boards Association. 1987. “American School Boards: The Positive Power." Washington: United States Department of Education, Office of Educational Research and Improvement (OERI). ERIC Document Reproduction Service, Accession No. ED290202, p. 26.
} 
"One thing is certain about the future: Children still will need to learn." 13

Educational leaders would be better prepared to address the future if they had some idea about what that future might contain and an understanding of the events and changes that might bring it about. "Often, the more advanced notice that's given about a coming activity, the better."14

Unfortunately, in attempts to address internal problems along with those of the greater society, educators often lack a sense of vision necessary to be considered effective. Hoy and Miskel defined problems as "difficulties that can be solved by past precedents or by the application of existing policy. Dilemmas are unsolvable within the existing framework." ${ }^{15}$ They also indicated that "Because dilemmas are endemic to organizations, they serve as perpetual sources of change."16 Any futuristic study which attempts to identify concerns or problems, then, would be representative of dilemmas in that there is no past precedent or existing policy available for their resolution.

The recent popularity of strategic planning has caused educators to consider the implications of the future. Planning, budgeting, assignment of responsibility, and development of workable timelines for implementation are all key components of strategic planning. Such planning represents the first step in the educational community toward avoiding "the social

\footnotetext{
${ }^{13}$ Iowa Association of School Boards and Iowa State Board of Education. 1994. School Board Leadership: The Future. Des Moines, February, p. 8.

${ }^{14}$ Stealy, Robert F. 1998. "Sometimes, the More Advanced Notice, the Better." Clarksburg Telegram, vol. 137, no. 31, (April 12). Clarksburg, WV: Clarksburg Publishing Co., p. A6.

${ }^{15}$ Hoy, Wayne K., and Cecil G. Miskel. 1996. Education Administration: Theory, Research and Practice. New York: McGraw-Hill, p. 417.

${ }^{16}$ Ibid, 417.
} 
disease of our time - short-term planning."

The future is particularly difficult to assess since it has not occurred and no facts about the future exist in the present. Data available from studies of the past cannot always be applied in studies of the future. "Much of the information about the future must be produced and assembled from the judgements of experts and other persons knowledgeable in areas related to specific research interests." 18

While strategic planning attempts to address the near-term future, the Delphi method of forecasting has been used to predict events from a short to a long-term basis. Typically, the Delphi technique utilizes a series of questionnaires which are mailed to a group of preselected respondents who remain anonymous to each other. In the first mailing, or round, the respondents generate a list of concise statements of events that they think have at least a fifty percent probability of occurrence in the future. In some cases, the list of events has already been stated for them. In the second round, the respondents are provided a list of all events and then asked to estimate when each event might occur in the future. In the third round, each respondent is given information about when the group thought each event would occur, and then has the opportunity to revise his/her estimates. If a respondent's revised estimate does not match the median response of the group, he /she is asked to offer an explanation as to why he/she thinks the event will take place in the time frame specified.

The Delphi can be used to project short-range, intermediate-range, and long-range events

\footnotetext{
${ }^{17}$ Bennis, On Becoming a Leader, 22.

${ }^{18}$ Stead, Floyd L. 1975. An Application of the Delphi Method of Forecasting to Nursing Education Planning in West Virginia. Doctoral Dissertation. Morgantown: West Virginia University, pp. 2-3.
} 
and propositions. In the past, futuristic studies have been hindered by the bias of the author, have lacked sufficient quantifiable data, or have lacked the ability to exceed immediate or extremely short-range predictions or propositions. "The strength, therefore, of Delphi is exhibited in the process of using several experts in a related area to gain a consensus opinion about events that are forecast to occur in the short-range, intermediate-range, and long-range future of the discipline. ${ }^{19}$

Delphi studies are conducted to identify future events within the context of present-day reality. When addressing the future, respondents can think futuristically since they are really expressing opinions based on their individual knowledge and understanding of reality. Questions about the future may be as valid with this approach as questions about the present would be. ${ }^{20}$ Emphasis of Delphi applications in public educational settings has centered on general educational goals and objectives for the future, curriculum planning, identification of problems faced by school systems, and the identification of essential student competencies. Further research on the future of public education is needed because of the commonality of problems and dilemmas faced by public school systems. Use of the Delphi method of forecasting enables the researcher to identify future events which can then be anticipated, planned for, and, if necessary, avoided. An application of the Delphi method of forecasting to the future of public education has, to date, not been attempted in West Virginia.

As history records and recounts the events of the past, the future will consist of events, many of which will remain unknown until their occurrence. Based on events of the past and what

\footnotetext{
${ }^{19}$ Ibid, 2-3.
}

${ }^{20}$ Flinchbaugh, Robert W. 1993. The 21st Century Board of Education. Lancaster, PA: Technomic Publishing Co., p. 170. 
we perceive to be currently happening, informed people may form opinions about the future. Through group consensus, the collective opinions of experts can be used to predict the future with some degree of confidence. These events may then be used as a resource for educational leaders to use in planning the future of public education in West Virginia. "Projections are a success if they stimulate thought and action oriented toward creating a more desirable future."21

\section{Statement of the Problem}

Using the Delphi method of forecasting, this study will provide information from an expert panel on the nature and types of events that will affect public education in West Virginia between the present and the year 2020 .

\section{Research Questions}

1. What events will occur that will affect public education in West Virginia between the present and the year 2020 ?

2. When will these events occur between the present and the year 2020?

3. What degree of impact will each of these events have, should it occur?

4. Will these events be desirable, or undesirable?

\footnotetext{
${ }^{21}$ Regional Research Institute. 1992. West Virginia Population Projections by County, Age, and Sex - 19902020. Morgantown: West Virginia University, p. 9.
} 


\section{Significance of the Study}

Most planning that occurs within the educational community is short-term. This study will provide information from an expert panel on the nature and types of events that will affect public education in West Virginia between now and the year 2020. By identifying what experts perceive the important events to be, educational leaders and decision-makers will be better informed and able to anticipate the events, when they might occur, what impact they might have, and how desirable they would be, should they occur.

Patterned after the method developed in Stead's ${ }^{22}$ Delphi study of nursing education programs in West Virginia, this study will also incorporate two aspects of "intuitive" forecasting: the Delphi technique and the Scenario. The Delphi technique uses a panel of experts who remain anonymous to one another. This eliminates any possibility of one panel member influencing the opinions of another. The Delphi also provides each panel member with the opportunity to review the responses of the other panel members, and then to reconsider their opinions on the time, impact or desirability of the events under consideration.

This study will provide, through the use of a scenario, a chronology of events listed by their expected time of occurrence based on consensus of the panel. Scenarios provide a valuable insight into future events and enable educators to anticipate the events, determine their immediacy, and plan for their occurrence. Delphi studies enable the identification of the possibilities of the future through the opinions of many who are knowledgeable and informed in their own particular areas of expertise.

\footnotetext{
${ }^{22}$ Stead, Floyd L, An Application of the Delphi Method of Forecasting to Nursing Education Planning in West Virginia.
} 
In addition to providing the anticipated time of the event, this study also will identify the impact and desirability levels of each event. Public school educators would like to have the good things happen sooner, and the bad things happen later, or not at all. This study will enable the education community to identify events with low levels of desirability which then may be avoided.

Information from this study will be valuable to the individuals included in the panel and to the groups they represent. These individuals include county school board members, superintendents, members of the West Virginia Legislature and other agencies of state government, representatives of the West Virginia Department of Education, the West Virginia School Boards Association, the West Virginia Association of School Administrators, the West Virginia Elementary and Middle School Principals' Association, the West Virginia Secondary School Principals' Association, the West Virginia Parent/Teachers Association, West Virginia Education Association, West Virginia Federation of Teachers, West Virginia Professional Educators, West Virginia Association of School Service Personnel, as well as representatives of Regional Education Service Agencies (R.E.S.A.s), higher education, practicing and prospective school administrators and teachers, service employees, parents, business and community leaders, members of other governmental agencies, and any other individuals who have contact with, or interest in, public education.

\section{Limitations}

This study is limited to data collected during the first semester of the 1998-99 school year, through consensus of a panel of experts representing various governmental and education-related agencies, institutions and constituencies found in West Virginia. The sample was limited to top 
level officials and administrators within these groups. Persons used on the expert panel were selected by their position and relationship to the educational community without regard for their geographical location, and/or by recommendation of heads of educational agencies.

There was considerable diversity among the panel members with regard to their age, background, education, and position. Although each has a relationship to public education, their diversity might have limited their individual perceptions and knowledge of educational issues. This diversity, however, might also be considered a strength as a wider spectrum of opinion might have been obtained.

Although great care was taken in the selection of the expert panel, there are others whose contributions might have been valuable to this study. The expert panel consisted of forty-seven individuals who are among the top educational leaders in West Virginia. While the researcher is comfortable with the quality, knowledge and skills of the persons selected, the sample size might have been expanded if more time were permitted for the study.

The size of the sample produced a variety of ideas from the panel members, some of which may be considered extreme. Through the need to establish consensus, Delphi studies tend to limit extreme ideas which might ultimately prove to be accurate. Although results will represent group consensus, they should not be considered a total representation of what the future might hold. Other possibilities may occur that will render the Delphi predictions inaccurate such as changes in political structure and declines in the economic condition of the state which would affect population and available revenue.

Every effort has been made to avoid any unintentional misinterpretation or misunderstanding of instructions by panel members which might jeopardize the desired results. 
Survey instruments were field tested to determine their level of clarity using individuals who have positions comparable to the members of the panel such as administrators and superintendents. The data received from the survey instruments was only as accurate as the honesty and thoughtfulness of the respondents. To facilitate communication and avoid misunderstandings and misinterpretations, day and evening telephone numbers, a mailing address, and the e-mail address of the researcher was provided to all panel members. This study was limited to the respondents' interpretation of instructions and timelines. Errors in interpretation of instructions were possible.

Prior to the study, the percentage of response from the panel could not be determined. A letter was sent to each panel member approximately one week prior to Round 1 of the Delphi to alert them of the upcoming arrival of the initial survey. The letter emphasized the importance of prompt response throughout the study. Every effort was made to insure a high rate of return. A projected response rate of 70 percent was expected for all three rounds of the study.

\section{Operational Definitions}

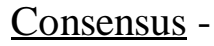

Delphi Technique -
General agreement of the panel at a level at or above eighty

percent. (See Primary Event, Secondary Event, Desirability and Impact)

The Delphi technique is the systematic assembling of a set of expert judgments about the likelihood of specific occurrences (events) in the future by designated time frames, impact of the occurrence, desirability of the occurrence, and reasoning behind the lack of 
consensus. $^{23}$

Delphi - Round 1 - $\quad$ Round 1 is the first issuance of the Delphi technique designed to generate and identify events which the panel of experts believe have a fifty percent probability of occurrence. ${ }^{24}$

Delphi - Round 2 - $\quad$ Round 2 of the Delphi technique represents the initial follow-up or feedback in which the panel of experts provide their initial responses to (1) the time frame in which each event will probably occur; (2) the desirability of the event, should it occur; and (3) the impact of the event, if it occurs. ${ }^{25}$

Round 3 of the Delphi technique is designed to refine, through group consensus, the time frame of each generated event and to provide the opportunity for each member of the group to explain any difference of opinion. ${ }^{26}$

Desirability Desirability is defined as something seen as beneficial or something that someone is eager to obtain. High Desirability is defined as a mean desirability rating which exceeds 5.00 on a seven-point Likert Scale. Low Desirability is defined as a mean desirability rating

\footnotetext{
${ }^{23}$ Ibid, 8 .

${ }^{24}$ Ibid, 10.

${ }^{25}$ Ibid, 10.

${ }^{26}$ Ibid, 10.
} 
between 1.00 and 2.99 on a seven-point Likert Scale. ${ }^{27}$

Education Reform -

Expert -

Forecast -

Impact -
A complete overhaul of the education system - a comprehensive attempt to rework the basic fabric of schooling, or a restructuring (rebuilding, reinvention, reformation, revolution, rethinking, or transformation) of the educational enterprise. ${ }^{28}$ An expert for this Delphi application is any one of forty-seven persons selected for participation on the basis of their skill and knowledge, their ability to affect and/or influence public education policy in West Virginia, and who are representative of the major public educational agencies, institutions and constituencies found throughout West Virginia.

A forecast is an opinion or estimate about a future happening or condition. $^{29}$

Impact is defined as the degree to which an event will result in having some significant effect on public education in West Virginia.

High Impact is defined as a mean impact rating which exceeds 5.00 on a seven-point Likert Scale. Low impact is defined as a mean impact rating of 1.00 to 2.99 on a seven-point Likert Scale.

${ }^{27}$ Ibid, 11.

${ }^{28}$ Murphy, J. 1990. "Restructuring America's Schools.” The Policy and Planning Center, Appalachia Educational Laboratory, Charleston, WV, and the National Center for Educational Leadership, Nashville, p. v. Virginia, 8.

${ }^{29}$ Stead, An Application of the Delphi Method of Forecasting to Nursing Education Planning in West 


\section{Likert Scale -}

Primary Event -

Scenario -

Secondary Event -

Site-based Management-

$\underline{\text { Strategic Planning - }}$

Time Frames -
A Likert Scale is defined as an ordinal measurement which assigns points to five or more categories measuring responses in a questionnaire. $^{30}$

Events which had eighty percent or above consensus.

A scenario is a systematic, analytical discussion of selected occurrences (events) by designated time frames representing shortrange, intermediate-range, and long-range forecasts in conjunction with an impact/desirability rating. ${ }^{31}$

Events which had between sixty to seventy-nine percent consensus. A form of decentralization that shifts planning, program implementation and accountability to the individual school. ${ }^{32}$ A planning process performed by the board of education and top level administrators which determines the mission and direction of the school system, and what resources will be committed to those ends. ${ }^{33}$

The time frames for this study are designed to be representative of short-range, intermediate-range, and long-range forecasts. The

\section{${ }^{30}$ Ibid, 11.}

${ }^{31}$ Ibid, 8.

${ }^{32}$ Boschee, F., Uhl, P. L., and J. A. Bonaiuto. 1993. "Barriers to Site-Based Management and Shared Decision Making, as Perceived by School Board Presidents and School Administrators." ERS Spectrum, vol. 11, no. 1, pp. 22-26.

\footnotetext{
${ }^{33}$ Young, Kenneth, and Powell Toth. 1985. “Master Plan for Excellence.” Unpublished position paper.
} 
experts have five options: (1) 1999-2000, (2) 2001-2010, (3) 2011-

2020, (4) After 2020, and (5) Never.

Short-Range - $\quad$ Short-Range events are limited to those events identified by the experts which are contained totally in the 1999-2000 time frame.

Intermediate-Range - Intermediate-range events are limited to those events identified by the experts which are contained totally in the 2001-2010 time frame.

Long-Range - $\quad$ The Long-Range events are those events wholly contained in the 2010-2020 time frame.

\section{Summary}

This chapter has presented an introduction to the research to be conducted. The reader has become acquainted with the need of educational leaders to be effective. The first basic tenets of leader effectiveness is that leaders have a sense of vision of the future. This vision can be refined if some insight into events of the future is available. The Delphi technique of forecasting, which utilizes the consensus of opinion from a panel of experts, will be used in this study to develop scenarios of events which may happen in the future. Such a forecast will enable educational leaders to anticipate these events and plan for their occurrence.

Chapter 2 will provide a representative review of the literature related to the future of American society, the future of American education, the future of school reform, the demographics of educational change, and the Delphi method of forecasting. Chapter 3 will outline the methodology used in the study. Chapter 4 will present the data from the three rounds 
of the Delphi. Chapter 5 will provide a scenario for the future of public education in West Virginia, a summary, conclusions, and recommendations for further study. 


\section{CHAPTER 2}

\section{Review of Literature}

This chapter includes a sampling of the literature on the future of American society, the future of American public education, future problems that will affect American public education, the future of school reform, demographic changes and the educational environment, and the Delphi method of forecasting. The writings presented in this chapter represent only a small portion of the literature related to the research problem of this study. This chapter does not provide an all inclusive summary of the literature on these topics, but is intended to present the key concepts related to the study of the future of public education in West Virginia.

\section{The Future of American Society}

Any discussion of the future of American society quickly reverts to an analysis of existing problems and their implications for the future. In their book, American Renaissance, Marvin J. Cetron and Owen Davies covered the entire spectrum of forecasting the future of American society, economics, culture and education. Their discussion of these aspects of the American experience was set against the backdrop of problems which have surfaced during the last twentyfive years. During that time, political corruption, assassinations, the Vietnam war, the hostage crisis in Iran, oil shortages, the disappearance of manufacturing jobs, the trade deficit and national 
debt have affected the stability of American society. Domestically, drug use has increased and schools have deteriorated. In Cetron's view, "Virtually all of the problems we face today survive, not because we cannot solve them, but because we have lacked the political will to do so." 34

While Cetron examined the future from a political perspective, other authors have cited various factors as key components in determining the future. Alvin Toffler, who in 1970 predicted the "fracturing" of the nuclear family, the genetic revolution, the rise of a throwaway society, and the reform revolution in education, examined the future through the process of change and how it affects people and organizations. Toffler coined the term "future shock" as the result of "the disorientation and stress brought on by trying to cope with too many changes in too short a time." 35 He argued that the simple speed-up of events and reaction times produces its own effects, and held that individuals, organizations, and even nations can be overloaded with too much change too soon, leading to disorientation and a breakdown in their capacity to make intelligent adaptive decisions. ${ }^{36}$

In their book America's Future: Opposing Viewpoints, Dudley and Szumski placed individualism at the center of the many problems facing American society today. They attempted to answer the question: "Can Americans work together to stem the economic and social crises that plague the nation, or will the United States become a second-rate power, torn asunder by individuals pursuing their own short-term material goals?" The authors contended that in their

\footnotetext{
${ }^{34}$ Cetron, Marvin J., and Owen Davies. 1989. American Renaissance, Our Life at the Turn of the 21 st Century. New York: St. Martin's Press, p. 4.

${ }^{35}$ Toffler, Alvin. 1970. Future Shock. New York: Random House, p. 4.

${ }^{36}$ Toffler, Alvin. 1990. Power Shift: Knowledge, Wealth and Violence at the Edge of the 21 st Century. New York: Bantam, p. xix.
} 
pursuit of individual interests and a better standard of living, Americans have lapsed into a state of complacency.

In the United States, the emphasis on individual rights, achievements, and goals has always been an important and appealing part of our nation's identity. Ironically, it is this same emphasis on the individual that many blame for the economic and social problems facing the United States today - it is a country of individuals, they say, who care little about the common fate of the nation. ${ }^{37}$

While most authors wrote about efforts to solve national domestic problems, Paul

Kennedy felt that the United States must deal with additional problems which have been selfimposed. Kennedy contended that the United States has overextended itself by carrying an immense military burden because it still perceives itself as the world leader it once was. The Vietnam experience and the inability to control events in the Persian Gulf were clear signals to him that unchallenged military might is in the past.

Attempting to defend too many fronts means devoting too large a proportion of its best scientific and skilled manpower to ends that do not add to the growth of the economy. If history teaches us anything, it is that an emphasis on military power over economic vitality leads to a deterioration of both. ${ }^{38}$

Kennedy was also concerned about America's massive domestic deficit and the unprecedented foreign deficit. Like Cetron, he agreed that America has lost its edge in manufacturing, and further contends that it has also lost its place at the apex of world finance.

\footnotetext{
${ }^{37}$ Dudley, William, and Bonnie Szumski, eds. 1990. America's Future: Opposing Viewpoints. San Diego: Greenhaven Press, p. 13.

${ }^{38}$ Kennedy, Paul. 1990. “The U. S. Is in Decline," interview by Robert Hielbroner, in America's Future: Opposing Viewpoints, William Dudley and Bonnie Szumski, eds. San Diego: Greenhaven Press, p. 22.
} 


\section{The Transformation of Industry}

Economically, science and technology have been the change agents resulting in the elimination of one-half of the manufacturing jobs that existed in the late 1970s. The proliferation of computers and related technologies has been responsible for this downward spiral in manufacturing jobs, and "in the next decade, half of the remaining manufacturing jobs will vanish under their influence." ${ }^{39}$ While computers have had a significant negative impact on jobs, Cetron observed that computers have served as a catalyst to solve one basic social problem by bringing families closer together since more and more individuals are working at home, while other families have deteriorated under the strain of being constantly together.

Alvin Toffler's Power Shift traced a time period from 1950 to 2025, a period which he referred to as "the hinge of history, the period in which smokestack civilization, having dominated the earth for centuries, is finally replaced by another, far different one following a period of worldshaking power struggles." ${ }^{40}$ As society transforms itself under the influence of the decline of manufacturing jobs and the rise in technology, Toffler questioned "what happens to people when their entire society abruptly transforms itself into something new and unexpected?' He felt that control of the future will depend on the use of violence, wealth and knowledge. ${ }^{41}$

Toffler contended that the most important economic development of modern times has been the rise of a new system for creating wealth, based no longer on muscle but on mind. He noted that the Japanese were first to embrace the idea that knowledge would be the key to

\footnotetext{
${ }^{39}$ Cetron and Davies, American Renaissance, 4-5.

${ }^{40}$ Toffler, Power Shift, xix.

${ }^{41}$ Ibid., 3.
} 
economic growth in the 21 st century. Japan moved quickly to substitute "knowledge-based technologies for brute muscle technologies."

What counts for each nation in the long run are products of mind work: scientific and technological research...the education of the workforce...sophisticated software...smarter management....advanced communications...electronic finance. These are key sources of tomorrow's power, and among these strategic weapons none is more important than superior organization - especially the organization of knowledge itself. $^{42}$

Projecting to the year 2050, Masse Bloomfield described the changes that he envisioned taking place that would turn a transitional industrial society into an automated society. He defined the "automated society as the product of merging computers, artificial intelligence, materials handling equipment and machine tools." ${ }^{43}$ Areas of activity where Bloomfield thought innovation will lead to the automated age include robots or automatic machinery, computers including control systems, biotechnology, energy, and space. "The country that conquers space will capture the minds of all humans...The country that leads in computers, robotics, space and automated factories is going to be the country that leads the world in the economic sphere, in the military sphere and in the technological sphere."44

\footnotetext{
${ }^{42}$ Ibid., 20.
}

${ }^{43}$ Bloomfield, Masse. 1995. The Automated Society; What the Future Will Be and How We Will Get It That Way. Canoga Park: Masefield Books, p. 130.

${ }^{44}$ Ibid., 100. 


\section{Future Population Trends}

As society undergoes this transformation, the size of the American population is expected to increase. Assessing the future population of America, Kennedy noted that "According to the World Resources 1990-91, p. 254, America’s population will rise from 249 million in 1990 to 301 million by 2025." Kennedy further forecasts that

there will be a larger percentage of elderly by the early 21 st century. By 2030 there will be more elderly people than children, and the political power of retirees' organizations will be greater, and there may not be as much support for education. Social security will run out. Latin and Asian populations of the United States will increase, and the Caucasian segment will continue to shrink. Racial tensions are expected to increase. ${ }^{45}$

Cetron also forecasted significant changes in ethnicity through the rise in Latin and Asian immigration. He predicted that by the year 2000, minorities will be the majority in fifty-three of the one hundred largest cities in the nation, a factor which could impact on the domination of politics in some areas. He identified two factors which are accelerating this change. First, birthrates are higher among minority groups than of the white majority. Birthrates among blacks are double the national average, and quadruple the national average among Hispanics. At the current rate of growth, Cetron predicted Hispanics to be the largest minority group in America by 2015. He concluded that by 2030 "minorities" will make up one-half of the American population, but noted that no one ethnic group will have the power to dominate the rest. In their individual group quest for dominance, increasing tensions will be a growing part of the American scene. The second factor is that "white flight" to the suburbs and rural areas will leave the cities to be

\footnotetext{
${ }^{45}$ Kennedy, Paul. 1993. Preparing For The Twenty-First Century. New York: Random House, pp. 311-312.
} 
centers for minorities. ${ }^{46}$

“Today almost one-third of our pupils are minorities, principally from Latin America and Asia. These changes are accelerating and are concentrated primarily in the schools of our central cities." ${ }^{47}$ According to a study sponsored by the American Association of School Administrators (AASA) and Allstate Insurance Company, white males will account for only 15 percent of the job force in the next twenty years. ${ }^{48}$ "Presently, nearly one in four of the net additions to the workforce is a black or Hispanic person."49

By 2010, if the demographers are right, one-third of all of the children in the United States will live in just four states - California, Florida, Texas, and New York. Those four states - according to A Demographic Look at Tomorrow, a report that extrapolates from the U.S. Census information - will see significant increases in the number of children in the next 20 years, mostly because of increases in what is now considered the minority population. ${ }^{50}$

Bloomfield considered the two most pressing and interacting problems facing mankind as being an exploding population and an imploding work force. These two trends reinforce the rise of unemployment in the world. "Just at the time when world population is growing, automation is beginning to make an impact in reducing the number of people needed in the work force."

Bloomfield indicated that despite concerns about overpopulation, increasing pollution and

${ }^{46}$ Cetron and Davies, American Renaissance, 23.

${ }^{47}$ Tanner, Daniel. 1993. “A Nation ‘Truly’ at Risk.” Phi Delta Kappan, vol. 75, no. 4, (December). Bloomington: Phi Delta Kappa, p. 293.

${ }^{48}$ Tunstall, Dorothy F. 1995. Is Your School Ready for the 21st Century? Washington: United States Department of Education.

${ }^{49}$ Plewes, Thomas J. 1992. “Workforce Trends, Workplace Trends: How They Dictate a Changing Education and Training Strategy." Paper presented at the Work Now and In The Future Conference, Portland, Oregon.

${ }^{50}$ Natale, Jo Anna. 1996. “Growing Up The Hard Way," in Straight Talk About America's Public Schools: Dispelling the Myths, Larry W. Barber, ed. Bloomington: Phi Delta Kappa, p. 95. 
decreasing resources, there is a lack of consensus, particularly by our political leaders, about the impending major disaster over the number of jobs available for our growing world population. Lack of available jobs may lead to frustration which could develop into an escalating number of minor skirmishes. Given this scenario, Bloomfield also indicated that "Crime has to increase in the scenario where there are three people for every job. Just imagine the social upheaval coming in the struggle between the haves and have-nots in the job market." 51

"By about 2010, manufacturing will probably employ little more than 10 percent of the labor force, maybe less." 52 "From 1940 to 1990, service industries' share of the United States employment went from 45 percent to over 70 percent." ${ }^{53}$

Since America is a major participant in the global economy and marketplace, changes in the condition of the world's population are equally significant. Paul Kennedy forecasted that the world population will also increase, particularly in developing countries as mortality rates are declining through advancements in health and food supplies. Kennedy predicted that 95 percent of the expected population growth between now and 2025 will be in developing countries, and these countries will see their population leave the rural, agrarian areas and move to the cities. ${ }^{54}$ Many will leave their developing homelands in search of jobs and higher wages in American cities. $^{55}$

\footnotetext{
${ }^{51}$ Bloomfield, The Automated Society, iv-v.

${ }^{52}$ McRae, Hamish. 1995. The World in 2020. Boston: Harvard Business School Press, p. 212.

${ }^{53}$ Perelman, Lewis J. 1992. School's Out. New York: Avon Books, p. 67.

${ }^{54}$ Kennedy, Preparing For The Twenty-First Century, 32.

${ }^{55}$ Thurow, Lester C. 1997. The Future of Capitalism. New York: Penguin Books.
} 
As the world's population expands, there will be an increased dependence on the United States as a continuing and stable source of food. Kennedy believed that the development of biotechnology is important in the production of a larger food supply. Biotechnology means "any technique that uses living organisms or processes to make or modify products, to improve plants or animals, or to develop microorganisms for specific uses." Legitimately, biotechnology could close the gap between the growing population and the available food supply. ${ }^{56}$

Socially, Cetron forecasted the shrinking of the upper and lower classes with an expansion of the middle class. His view of the future middle class in America as expanding rapidly and becoming more affluent and leisured was based in large part on the increasing number and earnings levels of two income families. Even if one wage earner loses his or her job or cannot work for some other reason, the other can carry on. People also are marrying later after they have established themselves financially and are having fewer children. Obviously, fewer people sharing a larger income allows the money to last longer. As the baby boomers age, the American work force will shrink, so employers will need to pay more in all sections of the job market. To fill the void, employers also will be forced to offer both basic education and job training. ${ }^{57}$

\section{America in Decline}

Each author reviewed had a different perception of America's future ranging from skeptical to optimistic. The proponents of the "School of Decline" maintained the basic positions that American power is now less than it was and will be matched by that of others, declines are

\footnotetext{
${ }^{56}$ Kennedy, Preparing for the Twenty-First Century, 70.

${ }^{57}$ Cetron and Davies, American Renaissance, 14.
} 
normal and explicable and are to be anticipated - especially considering heavy military spending and when such states do decline in power, the result is political instability and economic disorder in the international system. ${ }^{58}$

Paul Kennedy argued that America is in decline, much along the same lines of the decline of Britain and France during this century. Kennedy noted that as nations rise in power, their interests expand and they develop far-flung commitments and require fleets and armies to protect territories, with maintaining national power becoming more expensive. The ultimate problem becomes one of expanding the economic base to keep up with the expansion of its political and military role. Pointing to factors like America's decline in agriculture and the production of steel and automobiles, Kennedy noted that markets have shifted to Japan and other countries which have in turn invaded us with foreign products. "The United States is still the largest economic entity on the planet, but it is not any longer the entity whose performance puts it is a class by itself, hopelessly beyond the reach of any would-be competitor." Kennedy contended that "America is today, and will continue to be a great military and economic power - but not the only power." 59

Kennedy viewed the United States as a country whose ways of thinking and doing things are being challenged, and saw adaptation and flexibility as the keys to survival as a society and nation. He did not predict the demise of America, but felt that there is a need to remain flexible and adaptive by placing emphasis on infrastructure by establishing a first class educational system,

\footnotetext{
${ }^{58}$ Strange, Susan. 1990. “The U.S. Is Not in Decline,” in America's Future: Opposing Viewpoints. William Dudley and Bonnie Szumski, eds. San Diego: Greenhaven Press, p. 26.

${ }^{59}$ Kennedy, interview, 19.
} 
expanding basic scientific research, and emphasizing the production of scientists, engineers, and skilled workers of all kinds. Today, he noted, "this is not America's priority." 60

\section{Advancing America}

Susan Strange, in her 1990 article "The U.S. Is Not in Decline," took an opposing view to Paul Kennedy. She contended that today real power is associated with information-rich occupations, whether associated with manufacturing or not. While its world leadership as a manufacturing center has declined, the United States has grown rapidly in new fields of software services, biotechnology, medical products, data retrieval, environmental management or new basic materials. Strange contended that "we are creating a nonterritorial empire which is really our 'flourishing economic base.",61

Strange saw the current power of the United States as being based on the ability to: (1) offer, withhold or threaten security, (2) offer, withhold or demand credit, (3) determine the locus, mode and content of wealth-creating activity, (4) influence ideas and beliefs and the kind of knowledge which is socially prized and sought after, and (5) control access to and communication of that knowledge. ${ }^{62}$

Cetron and Davies were more optimistic - "We believe firmly that anyone who looks clearly at the facts, unbiased by any partisan political agenda, must feel an unfashionable optimism about the future of our country." They believed that the innate ingenuity of the American people will allow them to overcome the problems the United States faces in the next century. In looking toward the next century, Cetron indicated that "the United States at last faces a decision: We

\footnotetext{
${ }^{60}$ Ibid., 22.

${ }^{61}$ Strange, “The U.S. Is Not in Decline," 29.

${ }^{62}$ Ibid., 33.
} 
must either begin to solve the many problems we have neglected for so long or commit ourselves to a decline that will be almost impossible to reverse. Whether deliberately or by default, by the year 2000 we will have made our choice." ${ }^{93}$

While the United States continues to experience political and economic competition from abroad, and endless controversy at home, Cetron felt that America will have passed the crisis by the turn of the century. He stated that "the economy will be regaining its vigor. The school systems will be well on their way back to academic success. Urban crime rates will be dropping." 64

As mentioned previously, Cetron also forecasted

the rapid growth of an affluent, leisured middle class, eager for goods and services; the aging of the baby boom generation, with its growing need for personal conveniences and medical care; and the repair of the federal budget, which will lift several handicaps from the economy, will cause explosive growth in microelectronics, biotechnology and medicine. ${ }^{65}$

\section{The Rise in Skepticism}

As the only author to mention public opinion polls, Paul Kennedy claimed that "opinion polls show that most citizens feel things have worsened - in the social fabric, race relations, public education, economic performance, the conditions of the average American family - and will be worse for their children and grandchildren." 66

The American people also appear to have little faith in the ability of government to address

\footnotetext{
${ }^{63}$ Cetron and Davies, American Renaissance, 2.

${ }^{64}$ Ibid., 7.

${ }^{65}$ Ibid., 234.

${ }^{66}$ Kennedy, Preparing For The Twenty-First Century, 310.
} 
the problems of both today and in the future. Charles Greenawalt observed that there has been a rise in general skepticism in America.

The beginning of the 1990s has brought a deep distrust of governmental interference, of social programs aimed at repairing society, and of the ability of political institutions to cope with national problems. Mistrust is evident in politics through the term limitation movement, one-term presidencies, emergence of a third party, the rise of one-issue candidates, and low voter registration and turnout. ${ }^{67}$

Unfortunately, much of the impetus to address the problems facing America today is dependent on governmental action. The politicians talk about "hard choices" but won't say what the choices are and, when faced with choices, they learn quickly that change can be a painful process. Kennedy described the situation in one state where the legislature wanted to model Japan's 240 day school year. Consideration of this brought protests from the tourist industry, kids, parents, and from the teachers who wanted more compensation. Keenly aware of their own need to be re-elected, politicians are reluctant to offend voters and won't raise taxes to increase the growth potential of the nation. Kennedy concluded that with this type of political attitude, "America can remain a great power, but not the great power." 68

Politically, changes will be necessary to address the needs of an aging population, rebuild America's infrastructure, and reduce the national debt as well as the trade deficit. Government must be relied on heavily to address the needs of educational systems.

\footnotetext{
${ }^{67}$ Greenawalt, II, Charles E., ed. 1994. Educational Innovation: An Agenda to Frame the Future. New York: University Press of America, pp. x-xi.

${ }^{68}$ Kennedy, interview, 23-24.
} 


\section{The Future of American Education}

All of the authors cited in the previous section concurred that the transformation of American society from the industrial to the information age will change virtually every aspect of life in the United States. The economy will become more and more a participant in a global marketplace. Information will be obtained, sent, and stored electronically and will be available to virtually everyone. Scientific and medical research will become increasingly important in assuring that the world's food supply is adequate, and to solving the medical problems of cancer, AIDS, and other devastating diseases.

Politically, changes will be necessary to address the needs of an aging population, rebuild America's infrastructure, and reduce the national debt as well as the trade deficit. We must also rely heavily on government to address the needs of our educational systems.

\section{The Reliance on Education}

An effective and efficient system of education is the key to overcoming the many national problems. Increasingly, society has forced education far beyond its original concept of schooling to becoming America's great social service safety net. Schools often serve as scapegoats for the failure of other institutions and for social ills that they had no part in creating. ${ }^{69}$ "Public schools have been blamed for our lagging industrial sector, our loss of national moral fiber, and the deterioration of our common values and religious beliefs."70 Cetron noted that "At heart,

\footnotetext{
${ }^{69}$ Cobb, Nina, ed. 1994. The Future of Education: Perspectives on National Standards in America. New York: College Board Publications.

${ }^{70}$ Ascher, Carol, Norm Fruchter and Robert Berne. 1996. Hard Lessons, Public Schools and Privatization. New York: The Twentieth Century Fund Press, p. 1.
} 
America's social and economic problems stem from trying to run a complex nation with simple people." 71

Not only is education looked to as the answer to America's problems, it is also the main component in measuring one's ability to compete in our society. The rapid decline in manufacturing jobs has caused formidable social, economic, and educational problems with many displaced workers being forced to take jobs in service industries which pay considerably less. "The federal government has estimated that about half of the new jobs workers found in 1992 were part-time, temporary, and typically without good benefits."72 With wages lower, these people cannot compete socially with those who have retained their jobs. Some are also undereducated to make career changes. Retraining will be a central theme in the future of education. $^{73}$

Cetron and Davies viewed jobs of the future as falling into two categories: "the ones you don't want and the ones you can't get - not, at least, without extensive preparation." Bottom-end service jobs will increase while thousands of well-paid professional openings will be available for people with the good basic education and months or years of specialized training required to fill them. "Missing will be all those earn-while-you-learn jobs in manufacturing and trades that used to give high school grads, and even the occasional dropout, a route into the middle class."74

"The 'middle' of our society is declining, while rich and poor are increasing. We are

\footnotetext{
${ }^{71}$ Cetron and Davies, American Renaissance, 329.

${ }^{72}$ Tyack, David, and Larry Cuban. 1995. Tinkering Toward Utopia, A Century of Public School Reform. Cambridge: Harvard University Press, p. 39.

${ }^{73}$ Ibid, 39.

${ }^{74}$ Cetron and Davies, American Renaissance, 247.
} 
creating two work forces: one in minimum wage jobs, the other in well-paying jobs...This leads to an 'information-rich' and 'information-poor' split in our society.",75

Changes in technology will also render many careers obsolete. Almost everyone will need to be retrained for an entirely new job at some point as Cetron predicted that the next generation of workers will have to make no fewer than five complete job changes in their lifetime exclusive of multiple tasks assigned in current jobs due to downsizing and restructuring. ${ }^{76} \mathrm{He}$ also suggested that "people will have to "learn how to learn, to think and to communicate more effectively than ever before, and they will have to be able to do so with a flexibility to match the fast-changing demands made on them by the workplace of the future."77 Beyond the development of math and science skills, "We must insist upon learning about decision-making, problemsolving, evaluation, analysis, how to consider several ideas and merge them into an outstanding one. These skills turn jobs into careers." 78

Advances in technology will create an increase in the number of individuals who will work at home. More and more of the workforce will seek to choose its own hours, getting paid for the actual time worked. Home-based working will enable workers to choose their living areas, travel anytime, avoid transportation problems and potentially be with family members more. ${ }^{79}$

\footnotetext{
${ }^{75}$ Hodgkinson, Harold L. 1992. “A Demographic Look At Tomorrow,” in Straight Talk About America's Public Schools: Dispelling the Myths, Larry W. Barber, ed. Bloomington: Phi Delta Kappa, p. 157.

${ }^{76}$ Cetron and Davies, American Renaissance, 48.

${ }^{77}$ Cetron, Marvin J., and Marcia Appel. 1984. Jobs of the Future, The 500 Best Jobs - Where They'll Be and How To Get Them. New York: McGraw-Hill, p. 116.

${ }^{78}$ Ibid., 122.

${ }^{79}$ McRae, The World in 2020, 104.
} 
Changes in technology are also expected to continue to impact instruction.

Students will need to be skilled not only in accessing the vast array of information available through advanced technology, but in processing it as well. Because of the key role of technology in our society, students must know how to use computers and be familiar with various types of technology. To prepare students in this area, schools must incorporate 'marketplace' technologies in school and link with businesses that can share resources, expectations, and vision. ${ }^{80}$

"Computer literacy has become an essential skill children must develop if they are to become productive members in our technological society. Because of this, we have seen more and more computers installed in schools for use by students from kindergarten through twelfth grade." 81

School districts must now make decisions about expenditures for computers in the classrooms or in labs, the use of commercially available software, Internet connections, upgrading existing hardware, and computer replacement. "Our classrooms need to be wired so they can get on-line and take advantage of what the Internet has to offer. The problem is getting connected is not cheap. If schools paid to have the work done, it would cost about $\$ 1,000$ per classroom." 82 Districts have been willing to respond favorably to the increased demand for technology even before "we can fully comprehend the costs or time involved, much less the more fundamental issues of learning, development, or social organization where the impact of these decisions may be

\footnotetext{
${ }^{80}$ Uchida, Donna, Marvin Cetron and Floretta McKenzie. 1996. Preparing Students for the 21st Century. Arlington: American Association of School Administrators, p. 3.

${ }^{81}$ Knoblock, Ron. 1998. “Connecting Schools to Cyberspace.” Clarksburg Exponent-Telegram, vol. 73, no. 8, (November 29). Clarksburg, WV: Clarksburg Publishing Company, p. B3.

${ }^{82}$ Ibid, B3.
} 
felt." 83

Salomon and Perkins made two important observations about technology. They indicated that, first, the availability of computers in a classroom does not automatically cause teachers to alter their instructional methods. Second, "it has also become evident that no single task or activity, wondrous as it may be, affects learning in any profound and lasting manner in and of itself. Rather, it is the whole culture of a learning environment, with or without computers, that can affect learning in important ways." Salomon and Perkins also pointed out that what learning demands, not what technology can do, best points up the potential contributions of technology. ${ }^{84}$ The incorporation of technology into the instructional program is central to national efforts to bring schools up to date. In 1995, only 35 percent of all American public schools were hooked up to the Internet. One year later the number had risen to 50 percent. Federal communication legislation (e-rates) recently reduced the cost of Internet connections for schools. “Getting computers into America's classrooms has to be seen as just one step in our growing effort to move American education into the future." ${ }^{85}$

Cetron and Gayle agreed that technology has the potential to significantly change education, but are cautious about the ultimate value of classroom computers. They recognized all of the claims about how computers and other gadgetry have promoted learning, saved students

\footnotetext{
${ }^{83}$ Kerr, Stephen T. 1996. Technology and the Future of Schooling. Chicago: National Society for the Study of Education, p. 2.

${ }^{84}$ Salomon, Gavriel, and David Perkins. 1996. "Learning in Wonderland: What Do Computers Really Offer Education?" in Technology and the Future of Schooling, by Stephen T. Kerr. Chicago: National Society for the Study of Education, pp. 111-112.

${ }^{85}$ Riley, Richard W. 1996. "Education: The Gateway to America's Future.” St. Louis, (http://www.ed.gov/Speeches/02-1996/speech.htm), p. 8.
} 
from dropping out, and even saved whole schools from academic collapse, and felt it is likely that the average classroom a decade hence will be completely outfitted with all the high-tech conveniences that ten more years of development will offer.

Computers and telecommunications, in the hands of teachers who know how to use them effectively, could go a long way toward solving many of the problems that now beset our schools. Yet the reality is that while educational television and videodiscs will proliferate as quickly as schools can adapt to them, we cannot guarantee that computers will do the same. ${ }^{86}$

"Technology can relieve teachers from some of the more time-consuming and inefficient aspects of their traditional roles, such as imparting vast amounts of information in lectures."

Schools themselves will also change. "The schools of the $21^{\text {st }}$ century must reflect the ambiance of institutions where serious knowledge work occurs and where those who work are treated with dignity rather than as cogs in a machine" 87

Cetron and Gayle also envisioned technology as a key component in addressing another future educational problem. "If it turns out that, after raising pay scales and recruiting people from outside the profession, we still face a teacher shortage, as seems likely, then computerized instruction will be our only hope of making up the deficit." 88

\footnotetext{
${ }^{86}$ Cetron, Marvin, and Margaret Gayle. 1991. Educational Renaissance, Our Schools at the Turn of the Century. New York: St. Martin's Press, p. 110.

${ }^{87}$ Schlechty, Schools for the $21^{\text {st }}$ Century, 75-78.

${ }^{88}$ Cetron and Gayle, Educational Renaissance, Our Schools at the Turn of the Century, 103.
} 


\section{Fixing the Dilemma}

Cetron indicated that coping with the current problems faced by American education can be accomplished through the implementation of twelve measures, the first of which is increasing school budgets. He, like many others, felt that if quality education is desired in America, then it will have to be paid for. While federal spending was cut somewhat during the Reagan years, it is not surprising that teachers are still underpaid dramatically in relation to other professions which require a college education. Cetron noted that in 1987, in 40 out of 50 states, a starting garbage collector made more money than a starting teacher. Since then inroads have been made to raise salary levels and many more school systems are learning the lesson of paying more to attract and retain quality teachers. With the demands and expectations placed on American education increasing, fewer people are entering the teaching profession, opting for careers in higher paying professions. Future jobs in education will be found in the growing need for job retraining for displaced workers as a result of the current trends of downsizing, reorganization, restructuring, flattening the organization and out-sourcing. There will also be a need to replace teachers as the baby boomers retire. ${ }^{89}$

"Schools will need to hire 2 million new teachers over the next decade, according to projections, and states and districts are scrambling to find ways to stay ahead of the demand."90 Nationally, "enrollment growth, increased retirements, initiatives to reduce class sizes, and high staff turnover in some districts are fueling the market for teachers." ${ }^{91}$ Incentives such as signing

\footnotetext{
${ }^{89}$ Cetron and Davies, American Renaissance, 51-63.
}

${ }^{90}$ Bradley, Ann. 1998. "New Teachers Are Hot Commodity.” Education Week, vol. XVIII, no. 1, (September 9). Bethesda: Education Week, p. 1.

91 Ibid, 1. 
bonuses, housing and relocation assistance and higher starting salaries have emerged to attract teachers. It was also noted that "The concern about the supply of teachers coincides with increased attention to teacher quality. In the past, policymakers tended to lower standards to fill classrooms, but reformers are hopeful that the current interest in teacher quality will stave off such actions." 92

Cetron's other ideas involved hiring more teachers, thus creating smaller classes where more individualized instruction can take place, computerized instruction, working longer hours and increasing the number of instructional days to 210 by 2000 . "Common sense dictates that we can accomplish more in 8 hours than 6 , and in 210 days than 180 . We are the only country in the world without year-round school." He also feels that we need to let teachers teach by reducing red tape and rigid standardized curriculums. Cetron is one of many who want a standardized core curriculum noting that the United States is the only nation that leaves its curriculum solely to teachers. In his view, curriculum should be set nationally with advice from teachers, industry and trade unions, and high standards should be set that students should be expected to meet. The broadening of vocational options for students not intending to pursue higher education, the tailoring of courses to meet individual needs and learning styles, the promotion of students based on performance, and the utilization of corporate personnel in the schools to provide real-life experiences and expertise round out his scenario for improving American education. ${ }^{93}$

Uchida, Cetron and McKenzie noted the need for schools to better prepare students for the workplace through national School-To-Work initiative. Passed in 1994, the School-to-Work

\footnotetext{
92 Ibid, 1.

${ }^{93}$ Cetron and Davies, American Renaissance, 51-63.
} 
Opportunities Act "was designed to promote all students equal access to work-based and schoolbased learning through linkages between secondary and postsecondary education and employers." ${ }^{\text {94 }}$ School-to-Work facilitates the transition for students by "offering programs that combine learning in real work settings with learning in the school." ${ }^{95}$ Students declare a career major and earn credits for graduation within that major. Work experience, another component of School-to-Work, is provided to students within their chosen career major to develop positive work habits and instruction in workplace competencies." ${ }^{.96}$

Businesses will play an increasing role in public education through their participation in the School-to-Work initiative through work-based experience and mentoring programs. There has been some concern expressed that increased contact and dependence on business and industries to support public education programs, financially and in relation to the curriculum, may lead to an increase in commercialism in the schools. "People might object to commercialism at public schools, but they dislike tax hikes even more. To some parents, the barrage of commercialism is simply a matter of the end justifying the means." Should this develop, "review committees composed of parents, teachers and students will develop guidelines and limits to advertising and commercialism on school grounds." ${ }^{97}$

While Cetron approached the betterment of future schools through curricular means, Myron Lieberman emphasized reform in finance, governance, teacher qualifications, and special

\footnotetext{
${ }^{94}$ Uchida, Cetron and McKenzie, Preparing Students for the 21 st Century, p 64.

${ }^{95}$ Ibid, 64.

${ }^{96}$ Ibid, 64.

${ }^{97}$ Kniceley, Andy. 1998. “Ads in Schools: What Are We Teaching Our Children?” Clarksburg Telegram, vol. 137, no. 106, (December 9). Clarksburg, WV: Clarksburg Publishing Company, p. A4.
} 
programs. He promoted the voucher system, and the removal of educational restrictions which stifle teacher creativity and innovation. Lieberman advocated that parents pay for at least ten percent of the cost of education, and the completion of compulsory education by age 14 . A nationally accepted, not mandated, curriculum, especially in mathematics and science, and requirements for teacher examinations in the subjects they are employed to teach should also be established. He opposed schools being used as social melting pots, the public funding of cultural heritage programs and curricula intended to solve pressing social problems. Lieberman advocated state mandated report cards, home schooling, the abolition of school boards, and contracting out the management of the school district. Regardless of the ways in which education is approached in the future, "The primary focus of education must be on what students know and are able to do. 98

\section{The Move Toward National Standards}

One area in which the federal government may play an important role is in the push for national standards. Kirst and Guthrie attributed this effort to the lack of adequate local standards and high expectations, misleading standardized test results, and the need to accurately compare students for college admission and employment. They indicated that the National Assessment of Educational Progress (NAEP) is an apparent step toward national assessment. ${ }^{99}$

The United States is one of few developed societies lacking nationally mandated educational standards which are assessed by uniform national exams. "Any suggestion of copying

\footnotetext{
${ }^{98}$ Lieberman, Myron. 1993. Public Education: An Autopsy. Cambridge: Harvard University Press, p. 274.

${ }^{99}$ Kirst, Michael W., and James W. Guthrie. 1994. “Goals 2000 and a Reauthorized ESEA: National Standards and Accompanying Controversies," in The Future of Education: Perspectives on National Standards in America, Nina Cobb, ed. New York: College Entrance Examination Board, p. 160.
} 
the other democracies is resisted by school boards, education authorities, teachers' unions, and all who celebrate the country's decentralized traditions." Kennedy compared the American education system to Japan which has two hundred twenty instructional days compared to our one hundred eighty. On standard intelligence tests, students in Japan scored an average of one hundred seventeen while the average in America was one hundred. Japan is governed by a ministry of education which controls teachers' salaries, tests, curriculum, and physical plants. Kennedy further noted that "The United States devotes 6.8 percent of its GNP to education which is equal to Canada and the Netherlands and ahead of Japan, France or Germany."100

Gerald Bracey objected to comparisons of national educational systems due to the varying makeup of each society. He mentioned Japanese and Finnish schools which educate ethnic Japanese and Finns, respectively. He noted that in the United States, "large districts strive to teach students who speak as many as 108 languages other than English as their native tongues. Such a diverse and polyglot nation is not likely to show homogeneity on any variable." Bracey then looked at a stratified cross section of American students and concluded that "the top third of our students are world class, however one describes that squishy concept; the second third are not in any serious academic trouble; the bottom third are in terrible shape." 101

Robert Orrill supported the development of national standards for education so that, as a nation, there would be a more settled and commonly shared understanding of what public schools

\footnotetext{
${ }^{100}$ Kennedy, Preparing For The Twenty-First Century, 305.

${ }^{101}$ Bracey, Gerald W. 1993. “The Third Bracey Report on The Condition of Public Education.” Phi Delta Kappan, vol. 75, no. 2, (October). Bloomington: Phi Delta Kappa, p. 109.
} 
reasonably should be expected to do. ${ }^{102}$ Goals 2000: Educate America Act represents a step in this direction. Christopher Cross warned that teachers will not be encouraged or inspired by standards that they have little role in shaping, and it must be remembered that teachers are the ones who ultimately will determine if standards will be successful. ${ }^{103}$

\section{The Politicization of Public Education}

"Education policy touches on the mosaic of American values - religious, ethnic, professional, social, economic - that often clash in politics."104 "Educational reforms are intrinsically political in origin. Groups organize and contest with other groups in the politics of education to express their values and to secure their interests in the public school. Conflicts in education have arisen over ethnic, religious, racial, gender, and class differences." 105

The history of the school reform movement dates to 1893 and the report by The Committee of Ten, the first to criticize public education. The Committee concluded that students were ill prepared for high school and college courses based on the poor preparation they received in grammar school. Historically, "our schools have been assailed decade after decade - in the 1950s for letting America fall behind in the space and weapons races, in the 1960s for not bringing about integration fast enough; and in the 1980s for letting the country down in the global

\footnotetext{
${ }^{102}$ Orrill, Robert. 1994. "Titanic Structure of Human Scale: School Reform at the Close of the Twentieth Century," in The Future of Education: Perspectives on National Standards in America, Nina Cobb, ed. New York: College Entrance Examination Board, p. 5.

${ }^{103}$ Cross, Christopher T. 1994. "Implications of Subject-Matter Standards," in The Future of Education: Perspectives on National Standards in America, Nina Cobb, ed. New York: College Entrance Examination Board, p. 49.

${ }^{104}$ Wirt, Frederick M., and Michael W. Kirst. 1992. Schools in Conflict. McCutchan: Berkeley, p. 91.

${ }^{105}$ Tyack and Cuban, Tinkering Toward Utopia, A Century of Public School Reform, 8.
} 
marketplace - as well as coming under fire from national leaders who have had a strong ideological interest in changing the system." 106

Federal involvement in education increased after World War II when "it was felt that public education could increase the efficiency of industrial society by the proper selection and channeling of national manpower resources." This increase in involvement "was a direct result of national concerns about meeting manpower needs in the cold war and the demands of the civil rights movement."107 At this time, the federal government also "extended its role in education decisions about course content, school materials and curriculum were made at the national level by groups sponsored by the federal government or national professional organizations."108

In 1956, Vice-Admiral Hyman G. Rickover felt that "the United States was losing the technological and military race with the Soviet Union because America's public schools were failing to identify and adequately educate talented youth as future scientists and engineers."109 For Rickover, "the real military race was the race between educational systems" and "was to be won by the early identification and accelerated education of the talented and gifted." 110

Public schools were increasingly criticized after Sputnik, the Soviet space capsule, was launched in 1957. Again, the charge was that American school systems were failing to provide

\footnotetext{
${ }^{106}$ Bracey, Gerald W. 1996. "What Happened to America's Public Schools?: Not What You May Think,” in Straight Talk About America's Public Schools: Dispelling The Myths, Larry W. Barber, ed. Bloomington: Phi Delta Kappa, p. 40. McKay Co., p. 2.

${ }^{107}$ Spring, Joel. 1976. The Sorting Machine, National Educational Policy Since 1945. New York: David

${ }^{108}$ Ibid, 19.

${ }^{109}$ Ibid, 32.

${ }^{110}$ Ibid, 36, 37.
} 
the manpower necessary for scientific and technological competition with the Soviet Union.

James Bryant Conant, author of The American High School Today, also expressed concerns about the ability of the public schools to supply a steady flow of talented and trained manpower. Conant believed "that the educational system was the key element in maintaining the structure of the United States."111 Conant advocated the elimination of the small high school (any high school with fewer than one hundred students) in favor of the comprehensive high school which could provide enough varied and specialized programs. Conant also endorsed a strong guidance component which would begin in elementary school and be used "for sorting students according to ability and interest." 112

In response to the basic issues of the cold war, the need to effectively channel manpower, and the general criticisms of the public schools, the federal government passed the National Defense Education Act (N.D.E.A.) in 1958. ${ }^{113}$ The N.D.E.A., along with educational foundations, provided funds for the development and national distribution of new curricula in science, mathematics, and foreign languages, each of which was considered to be vital in the international race for global power with the Soviet Union. Federal funds were also made available to local school districts which allowed them to purchase the new curriculum materials. ${ }^{114}$

Between 1965 and 1972, the role of the federal government expanded as more funds were allocated to support changes in policy initiatives and an increasing number of discrete programs.

\footnotetext{
${ }^{111}$ Ibid, 44.

${ }^{112}$ Ibid, 47.

${ }^{113}$ Chubb, John E., and Terry M. Moe. 1990. Politics, Markets \& America's Schools. Washington: The Brookings Institution, p. 7.

${ }^{114}$ Spring, The Sorting Machine, 93.
} 
At this time "the percentage of federal aid peaked at 9 percent of total school expenditures." The period which followed and lasted until 1980 was one of increasing federal regulation and alignment of programs with federal education objectives. ${ }^{115}$

The establishment of the U.S. Department of Education under the Carter Administration held out the promise that the cause of American public education would be well served at long last at the federal level. Unfortunately, the Department of Education has failed to deliver on this promise. In fact, under recent secretaries the department has tended to function as a launching pad for attacks against the public schools. The failure of the department to serve as a voice and conscience for the public interest - as opposed to special interests in education - has left the public schools buffeted by conflicting waves of reform and counter-reform in successive eras. ${ }^{116}$

A Nation at Risk: The Imperative for Educational Reform was released by the National Commission on Excellence in Education in April of 1983 during the Reagan Administration and under then-Secretary of Education Terrell Bell. "This report, along with several similar reports, initiated the current discussion about our nation's public education system and provided the impetus for the ongoing reform movement in the public schools." 117

"The authors of A Nation At Risk launched a crusade for school reform by claiming that America was drowning in "a rising tide of mediocrity." 118 The report itself proclaimed that our educational failures were equivalent to "an act of unthinking, unilateral educational

${ }^{115}$ Wirt and Kirst, Schools in Conflict, 370.

${ }^{116}$ Tanner, Daniel, “A Nation ‘Truly’ at Risk,” 297.

${ }^{117}$ Barber, Larry W., ed. 1996. Straight Talk About America's Public Schools: Dispelling the Myths. Bloomington: Phi Delta Kappa, p. 17.

${ }^{118}$ Bracey, Gerald W. 1996. “Why Can't They Be Like We Were?, in Straight Talk About America's Public Schools: Dispelling the Myths, Larry W. Barber, ed. Bloomington: Phi Delta Kappa, p. 202. 
disarmament."119

"Risk embraced a new and powerful assumption: that the schools are tightly linked to the performance of the U.S. economy and our ability to compete in the global marketplace." It “depicted grave problems," and "seemed likely to generate money to fix those problems. Educational organizations accepted the report enthusiastically."120

As educators embraced the report, the American people assumed that its contents were accurate. "So many people have said so often that the schools are bad that it is no longer a debatable proposition subject to empirical proof. It has become an assumption."121 "Goodhearted Americans have come to believe that the public schools of their nation are in a crisis state because they have so often been given this false message by supposedly credible sources."122 As perceived by the public, "A Nation at Risk marked the return of the owners after a long absence to find education's house badly deteriorated."123

The message from Washington, D. C., that America's schools were on the verge of collapse and needed to be completely restructured, was embraced by those both inside and outside of the education establishment. Some embraced it out of ignorance while others did so in the sincere belief that convincing the American public that the public schools are in a state of collapse

\footnotetext{
${ }^{119}$ National Commission on Excellence in Education. 1983. A Nation At Risk. Washington: United States Department of Education, p. 5.

${ }^{120}$ Bracey, “What Happened to America's Public Schools?: Not What You May Think,” p. 47.

${ }^{121}$ Bracey, “The Third Bracey Report on the Condition of Public Education,” 202.

${ }^{122}$ Berliner, David C., and Bruce J. Biddle. 1996. The Manufactured Crisis - Myths, Fraud, and the Attack on America's Public Schools. Reading, MA: Addison-Wesley, p. 3.

${ }^{123}$ Hodgkinson, Harold. 1996. "Reform Versus Reality," in Straight Talk About America's Public Schools: Dispelling the Myths, Larry W. Barber, ed. Bloomington: Phi Delta Kappa, p. 194.
} 
was the only way to gain support for addressing the very real problems those schools faced. Still others endorsed the message because it served their own self-interest. ${ }^{124}$

Berliner and Biddle coined the "unwarranted, vigorous, and damaging attack" on American education a "Manufactured Crisis." Claims that schools had deteriorated and compared poorly with schools from other advanced countries, and that our nation's economy and future were seriously threatened "were said to be supported by evidence, although somehow that evidence was rarely cited or appeared only as simple, misleading analyses of limited data."125

"The crisis was indirectly generated by escalating problems, both in the larger society and in education itself; but it was also promoted by specific groups of ideologues who were hostile to public schools and who wanted to divert attention from America's growing social problems." The attention given to public education in the early 1980s "distracted Americans from the real problems of American education and from thinking about useful steps that we might take to resolve those problems and improve America's schools." 126

A Nation at Risk had "served the purposes of both those who want to provide more resources for the schools and those who want to overhaul the system and introduce privatization. Both sides have appeared to welcome only bad news about the schools." 127

In September, 1989, a national governors' conference on education was convened in

\footnotetext{
${ }^{124}$ Rose, Lowell C. 1996. "Straight Talk About The Public Schools" in Straight Talk About America's Public Schools: Dispelling the Myths, Larry W. Barber, ed. Bloomington: Phi Delta Kappa, p. 163. Schools, 343.

${ }^{125}$ Berliner and Biddle, The Manufactured Crisis - Myths, Fraud, and the Attack on America's Public

${ }^{126}$ Ibid, 343-344.

${ }^{127}$ Bracey, "What Happened to America’s Public Schools?: Not What You May Think,” 51.
} 
Charlottesville, Virginia. As a result of the conference, the Bush administration framed America 2000, the national goals for education. Released in April of 1991, these goals were the basis for President Bush's strategy for school reform. Also in response to the governors' conference, the United States Department of Energy commissioned a study which produced The Sandia Report. This "large, federally funded report concluded that there was no crisis in American education," 128 and the report was "effectively suppressed by the Bush administration when the data contradicted most of the allegations, premises, and proposals on which America 2000 was based. Ultimately, The Sandia Report was published during the Clinton administration "in the May/June 1993 issue of the Journal of Educational Research, a publication with a very small circulation," ${ }^{129}$ under the title "Perspectives on Education in America." 130 The Sandia Report had undergone scrutiny from the National Science Foundation and the United States Department of Education, neither of which could refute the data. ${ }^{131}$

The Sandia Report documented that, in actuality, the study found improving trends "on nearly every measure," including standardized test scores on college entrance exams, the National Assessment of Educational Progress (NAEP), and the Graduate Record Exam (GRE)." ${ }^{132}$ In addition, the dropout rate was lower, more college degrees were being earned in mathematics and

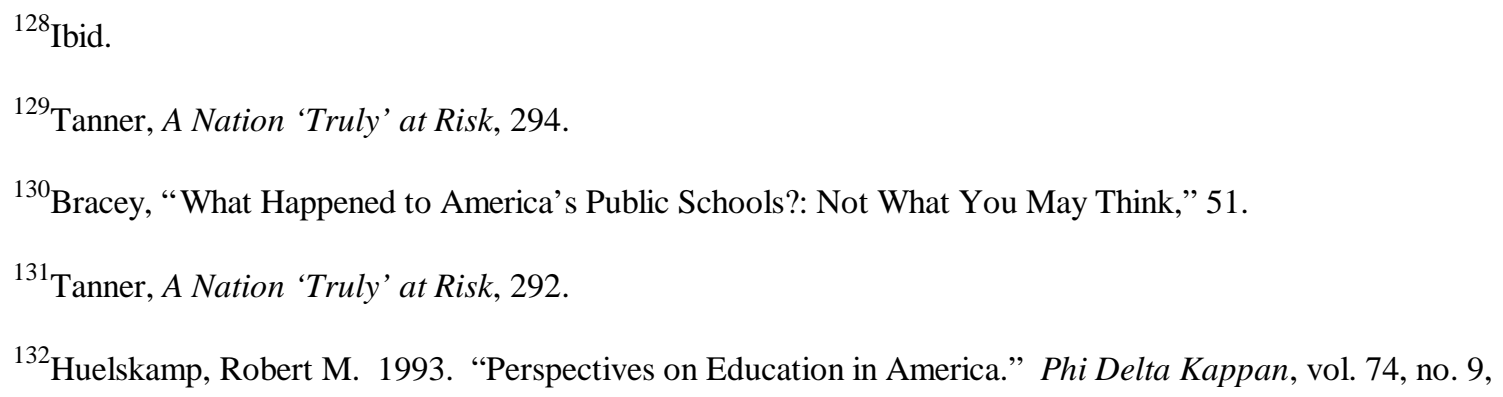


science, and teacher salaries had remained constant between 1970 and $1990 .^{133}$

The Sandia Report focused attention on the need to address the educational needs of the increasing number of minorities, due in part to immigration, particularly in urban areas. "The Sandia Report also raised serious questions about blaming the schools for our nation's industrial decline in the global marketplace and about seeking to subordinate the schools to narrow industrial interests." 134

During the early 1990s, there was a renewed and heightened interest in education reform over issues such as national teacher certification, a national curriculum, nationwide subject matter exams, break-the-mold schools, and vouchers. Many of the reforms were supported by the Republicans who were "more enthusiastic about public aid to private schools than Democrats." 135

"The basic influence today is much the same as in the early 1980s - widespread public concern that poor education is connected to slow U.S. economic growth and U.S. problems with international economic competition."136 "The debate over schools and their relationship to the economy has been accompanied by a shift in talk about the purposes of schooling. The goals of building citizens or broadly educated or well-rounded adults have been left behind in favor of the need to prepare students to get jobs and to provide skilled workers for business. ${ }^{137}$ "Recent

\footnotetext{
${ }^{133}$ Tanner, A Nation 'Truly' at Risk, 292-293.

${ }^{134}$ Ibid, 293.

${ }^{135}$ Wirt and Kirst, Schools in Conflict, 3.

${ }^{136}$ Ibid, 2.

${ }^{137}$ Bracey, “What Happened to America's Public Schools?: Not What You May Think," 51.
} 
education policy has focused more on quality than on equity." 138

Several authors indicated that the lack of consensus of the American public about the basic purposes of education is an impediment to educational reform. "The biggest threat to the American educational system may come not from within our schools but from the depth of our divisions over what exactly they should accomplish and how best to get them to accomplish it."139

Diane Ravitch concurred with Bracey and suggested that transformation of our educational system will not take place soon and that, ultimately, we will get the schools we deserve. She indicated that the basic problem in transforming our schools is a lack of consensus about whether all students should be exposed to a common curriculum and whether there are knowledge and skills everyone should have.

If we believed that it was important to have a highly literate public, to have people capable of understanding history and politics and economics, to have citizens who are knowledgeable about science and technology, to have a society in which the powers of verbal communication are developed systematically and intentionally, then we would know what we wanted of our schools. Until we do, we get the schools we deserve, which accurately reflect our own confusion about the value of education. $^{140}$

"A critical need today is to negotiate a common ground of purpose sufficiently generous, compelling, and plausible that it can unify citizens in support of public schooling." $" 141$

Until there is some degree of consensus about the basic purposes of education, what will

\footnotetext{
${ }^{138}$ Wirt and Kirst, Schools in Conflict, 2.

${ }^{139}$ Bracey, “What Happened to America’s Public Schools?: Not What You May Think,” 52.

${ }^{140}$ Lamm, Richard D., and Richard A. Caldwell. 1996. "Don't Blame the Schools for Changes in Values,
} Culture, and Families," in Straight Talk About America's Public Schools: Dispelling the Myths, Larry W. Barber, ed. Bloomington: Phi Delta Kappa, p. 255.

${ }^{141}$ Tyack and Cuban, Tinkering Toward Utopia, A Century of Public School Reform, 140. 
be taught will continue to be determined by those who develop curriculum. Testing programs and textbook publishers "have come to drive the school curriculum. And not only are they instruments of educational policy, but they also serve to shape educational policy...whereas we once mainly believed that educational policy was to be shaped by our highest, widest, and deepest social ideals, it is now to be shaped by our biggest test maker." ${ }^{\prime 42}$ How the curriculum will be delivered will remain a local decision.

Conflict over the very purpose of education has also arisen at the local level as "groups formed around some important local issue and eventually expanded their concerns to the general educational philosophy of the school." ${ }^{143}$ Special interest groups compete for the reallocation of school resources. Constituencies include parents, students, teachers, taxpayers, minorities, and federal and state authorities who may have a vested interest in special education programs, multicultural education, or the disadvantaged. ${ }^{144}$

As public interest and participation in education have increased, the schools have frequently been "caught between the forces of popular participation and bureaucratization. Over time, the latter prevails, but also through time the influence of citizen participation becomes a zone of tolerance within which school authorities must act." ${ }^{\prime 145}$ In response to the rising level of activity of special interest groups and their effect on local educational issues, Lutz and Iannaconne developed "the dissatisfaction theory of democracy" which "asserts that voters' dissatisfaction

\footnotetext{
${ }^{142}$ Tanner, A Nation 'Truly' at Risk, 290.

${ }^{143}$ Spring, The Sorting Machine, 8.

${ }^{144}$ Wirt and Kirst, Schools in Conflict, 3-9.

${ }^{145}$ Ibid, 90-91.
} 
rises as the gap between their values and demands and those of board members and superintendents increase." Their theory is most applicable in areas where there is a high rate of population turnover in which the values of the new residents differ from those of the older residents. "At some point, the dissidents become strong enough to defeat board incumbents, and a new board replaces the superintendent."146

The reform movement also brought about questions and concerns about the effectiveness of school boards. "One major reason is the lack of attention to school boards in virtually all the major national and state reports on education from 1983-86." By not discussing school boards, "the unstated implication of many reports is that school boards are part of the problem and have not exercised leadership and their authority to improve education. This message further implies that boards need to be circumvented, if not through direct state regulation, then certainly through vastly increased state prescriptions and monitoring." Local school boards have been either ignored, portrayed as "weak reactors or even deterrents, rather than as partners in shaping education improvement. Many school boards contend, however, that they initiated and enacted most of the reforms in local districts prior to state action." 147

Within their own communities local school boards have only infrequent interaction with other governmental and community service agencies. "Very little systematic communication takes place between school boards and general government, despite the fact that even more students have learning problems associated with nonschool factors such as poor housing, lack of family support and resources, and drug dependencies." This lack of involvement has caused some urban

\footnotetext{
${ }^{146}$ Ibid, 151.

${ }^{147}$ Ibid, 160-161.
} 
community leaders to reconsider the nonpartisan nature of school board elections in favor of conducting board elections through mainstream party structures. ${ }^{148}$

"At its best, debate over purpose in public education has been a continuous process of creating and reshaping a democratic institution that, in turn, helped to create a democratic society." "I49 "If we Americans truly want to improve our schools, not destroy them, we must begin with a realistic appraisal of what they accomplish."150 While still in need of improvement, “...U.S. public schools remain the best and most important means available to address the very real social and economic problems this country faces."151

\section{Social Problems and the Schools}

Like Liebermann, Robert Orrill noted that much of what impedes progress in public schools is the amount and number of diversions into non-academic pursuits and asked why schools are responsible for solving the nation's social problems. "Far too often, schools serve as scapegoats for the failure of other institutions and for social ills that they had no part in making. The resulting "bashing" of schools and teachers helps nothing and hinders constructive action."152

Dennis Rittenmeyer supported Orrill's position on schools being expected to solve national social problems. He pointed out that as student performance has declined, little attention

${ }^{148}$ Ibid, 162.

${ }^{149}$ Tyack and Cuban, Tinkering Toward Utopia, A Century of Public School Reform, 142.

${ }^{150}$ Rothstein, Richard. 1998. The Way We Were? The Myths and Realities of America's Student Achievement. New York: The Century Foundation Press, p. 7.

${ }^{151}$ Rose, Straight Talk About The Public Schools, 165.

${ }^{152}$ Orrill, “Titanic Structure of Human Scale: School Reform at the Close of the Twentieth Century,” 5. 
has been given to the societal changes which have taken place, and the increasing responsibility imposed on schools to address the problems created by social change has been ignored. ${ }^{153}$

"A child's educational achievement springs not only from the quality of schooling but also from health, motivational, family, and cultural conditions - many of which are set in the earliest of years - for which schools are not responsible."154

In a recent national survey conducted by the Carnegie Foundation for the Advancement of Teaching, nearly 80 percent of the teachers interviewed believe that most of the causes for school failure have to do with things over which teachers have little control - parental support, nutrition, child abuse, and so on. ${ }^{155}$

Alvin Toffler also characterized contemporary education as an American institution victimized by the problems of society. "An acknowledged disaster area for America is its factory-style school system, devastated by drugs, violence, and alienation." He perceived education as being in such a bad state that a

profound reconceptualization is now required, reaching far beyond questions of budgets, class size, teacher pay, and the traditional conflicts over curriculum. What is required is a proliferation of new and diverse programs. Significantly, education is no longer merely a priority for parents, teachers, and a handful of education reformers, but for the advanced sectors of business as well, since its leaders increasingly recognize the connection between education and global competitiveness. ${ }^{156}$

In Public Education: An Autopsy, Myron Liebermann agreed with Toffler that American education faces tremendous needs. The opening paragraph of Liebermann's book set the tone for

\footnotetext{
${ }^{153}$ Rittenmeyer, Dennis C. 1990. "Social Ills Make School Reform Impossible," in America's Future: Opposing Viewpoints, William Dudley and Bonnie Szumski, eds. San Diego: Greenhaven Press, p. 226.

${ }^{154}$ Rothstein, The Way We Were? The Myths and Realities of Americas' Student Achievement, 48.

${ }^{155}$ Schlechty, Schools for the Twenty-First Century, 140.

${ }^{156}$ Toffler, Power Shift, 368-369.
} 
his work:

Like individuals, social institutions die, and their death forces us to face an uncertain future. To be sure, an autopsy implies that the subject is dead, and I intend that implication. What has died is the rationale for public education. According to this rationale, public education effectively fosters basic skills, scientific and cultural literacy, civic virtues, and desirable habits and attitudes toward our society and its institutions. When public education does not produce these outcomes, the rationale assumes that "educational reform" will remedy the situation. This rationale is beyond life-sustaining measures. ${ }^{157}$

Liebermann identified three factors which explained the demise of public education. These included social and demographic changes that weaken public education such as the aging population, policies governing or regulating or implementing public education that contribute to its loss of public support; i.e., sex education, grading, and the emergence of a market system with parental choice which will move education away from government control and involvement. ${ }^{158}$

Richard Rothstein concluded that

social and economic characteristics interact with pedagogical practice to produce school success or failure. If this is true, however, the Americans concerned with academic achievement might get more 'bang for their buck' if they concentrated more reform energies on remedying some of the scandalous socioeconomic conditions that are known to cause poor student performance. ${ }^{159}$

\footnotetext{
${ }^{157}$ Lieberman, Public Education: An Autopsy, 1.

${ }^{158}$ Ibid., 3.

${ }^{159}$ Rothstein, The Way We Were? The Myths and Realities of Americas' Student Achievement, 112.
} 


\section{An Optimistic Future}

Cetron forecasted large-scale automation to aid a shrinking workforce, the emergence of new medical therapies that will offer longer and healthier lives, and computers that will streamline not only business, but educational practices as well. The complexity of what will be learned also will increase.

The class of 2000 will be exposed to more information in one year than their grandparents were in an entire lifetime. By the time today's kindergartners graduate from high school, the amount of knowledge in the world will have doubled at least 4 times. By 2010 there will hardly be a job that doesn't require skills in the use of computers and telecommunications systems. ${ }^{160}$

Cetron was also optimistic about America's ability to repair its schools. "Computers, educational software, and tailored curricula will make it easier to learn; business will contribute both personnel and money to help make the system work" and day care will provide education for children and education opportunities for their parents.

Without educational reform, none of the other changes we anticipate can alone keep the United States prosperous and strong. But with an educated, creative, hardworking and technologically sophisticated populace - and just a few policy changes in Washington - America will regain the prosperity it enjoyed in the 1950s and has been losing ever since. Ironically, while people talk of improving schools and willingly lend their support for improvements, Washington has attempted repeatedly to cut federal aid to education. ${ }^{161}$

Lester Thurow agreed with Cetron that reform efforts would be necessary to maintain an educated populace and to keep America competitive. He noted that "more money is required but an aggressive program of reeducation and reskilling the bottom 60 percent of the workforce

\footnotetext{
${ }^{160}$ Cetron and Davies, American Renaissance, 63.

${ }^{161}$ Ibid., 329.
} 
would require a fundamental painful restructuring of public education and on-the-job-training."162 Such programs are becoming more necessary as the skills that will be required in the future do not match those of the existing workforce. Funding for re-education programs will become more difficult to secure since "Social investments such as education are being crowded out of government budgets to pay for pension and health benefits for the elderly." ${ }^{163}$ Thurow also stated that "educational budget cuts are easier than most others, since nothing happens in the short run when school budgets are reduced." 164

As consumer spending continues to rise, and the public's willingness to pay taxes falls, investments for public education that used to be made will become more difficult to obtain in the future. In addition to re-educating the workforce, "in the years to come, many of the services, materials, and skills of education will be revamped to focus on the needs, styles, and preferences of an increasingly older student population." ${ }^{165}$ Education which has traditionally prepared the young for their careers will extend to meet the needs of those who now view learning as a lifelong process. Although the need for re-education will continue to grow, "interest in non-vocationaloriented education will increase as well." 166

\footnotetext{
${ }^{162}$ Thurow, The Future of Capitalism, 253.

${ }^{163}$ Ibid., 77.

${ }^{164} \mathrm{Ibid}, 263$.

${ }^{165}$ Dychtwald, Ken, and Joe Flower. 1989. Age Wave, The Challenges and Opportunities of an Aging America. Los Angeles: Jeremy P. Tarcher, Inc., p. 150.

${ }^{166}$ Ibid, 94.
} 


\section{The Role of Government}

While current rhetoric espouses a return of decision-making power to the states, continued involvement of the federal government in education will center on funding programs that will address national problems through the states. "Education is a national concern, a state responsibility, but it remains a local function." 167 Through its regulations, the federal government will control delivery of programs and services at the local level, thus constraining local autonomy. Both Loveless ${ }^{168}$ and Greenawalt see the involvement of the federal government in education as sustaining the rise in general skepticism in America. This skepticism began in the early 1990s when the federal government came under increasing criticism for the inability of its social programs to solve the nation's social problems. "The movement towards choice, entrepreneurial and charter schools, home schooling, privatization, parochial education, and equity challenges are symptoms of a general skepticism of central authority and government's ability to provide excellent and affordable education." 169

\section{Problems Created By Society}

While there are expectations placed on government to provide leadership and direction in addressing America's problems, implementation of changes and/or programs ultimately falls to the schools. Kennedy stated however, that "The crisis is not in the schools, but in us. The society we

\footnotetext{
${ }^{167}$ Weil, Nellie C. 1987. "The Significance of Being a School Board Member," in American School Boards: The Positive Power. Alexandria: National School Boards Association, p. 4.

${ }^{168}$ Loveless, Tom. 1994. "The Politics of National Standards," in The Future of Education: Perspectives on National Standards in America, Nina Cobb, ed. New York: College Entrance Examination Board, p. 53.

${ }^{169}$ Greenawalt, Educational Innovation: An Agenda to Frame the Future, p. x.
} 
have constructed has given us the education we deserve." 170

The most recent Phi Delta Kappa/Gallup Poll on attitudes toward public education reveals that fighting/violence/gangs, lack of discipline, lack of financial support, drug abuse, overcrowding, and concerns about standards/quality education are all included in the list of the biggest problems with which public schools must deal. Interestingly, the first four problems on the list are products of the society with which the schools must contend. ${ }^{171}$

Lamm and Caldwell stated that "schools are a symbolic mirror in which we see reflected the problems of our entire nation. They are the generational way station in which we glimpse our future." They further suggested that "much of the problem with the American education system lies outside the realm of the schoolroom and is not subject to correction within the school room." While they recognized that the American education system had its shortcomings, they felt schools were largely "products of their environment, and the fundamental determinants of educational success or failure are found in the larger social and valuational setting in which the school operates." What was needed were changes in "American values, behavior, and culture."172 As the problems of society have become the problems of the schools, 71 percent of Americans believe it is more important to teach values than academics, according to a recent study by the Public Agenda Foundation. Business leaders worry understandably about having a skilled labor pool that will help maintain a competitive advantage in the global economy, but the vast majority of Americans are much more worried about the apparent disintegration of social norms. Public Agenda's newest study of student attitudes toward school found that, while many high school students feel academically unchallenged, they are equally concerned

\footnotetext{
${ }^{170}$ Kennedy, Preparing For The Twenty-First Century, 308.
}

${ }^{171}$ Rose, Lowell C., and Alex M. Gallup. 1998. "The 30th Annual Phi Delta Kappa/Gallup Poll of the Public's Attitudes Toward The Public Schools.” Phi Delta Kappan, vol. 80, no. 1, (September). Bloomington: Phi Delta Kappa, pp. 41-56.

${ }^{172}$ Lamm and Caldwell, “Don’t Blame the Schools for Changes in Values, Culture, and Families,” 253-254 
about the lack of respect and civility in the schools. Sixty-nine percent of the students surveyed said that they would learn 'a lot more' from teachers who respected them. ${ }^{173}$

The relationship between the schools and their environment was also addressed by Lowell Rose who stated that "America's public schools mirror our over-indulgent, self-satisfied society." Rose further indicated that children do not spend enough time in school, and that schools "are plagued by all too real problems that keep children from learning - problems that society has failed to address. The schools are, for many good reasons, the ones that come closest to being in a "state of collapse." 174

Berliner and Biddle identified nine social problems that impact the education of children in America. These included the inequitable distribution of wealth; stagnation in the nation's economy; racial, ethnic, religious, and linguistic diversity; prejudice and discrimination; the deterioration of urban areas and the emergence of the affluent suburbs; violence and drugs; the aging of the population; competition for existing funds, and the restructuring of work brought about, in part, from the emergence of technology. ${ }^{175}$

Cetron contended that the role of parents was central to resolving many of America's education problems. The deterioration of the family unit caused the career orientation of many of today's two income homes, and the increasing dependence on child care, rising divorce rates, and the emergence of single parent homes all impact on the support children need to be successful in

\footnotetext{
${ }^{173}$ Wagner, Tony. 1998. “Change as Collaborative Inquiry.” Phi Delta Kappan, vol. 79, no. 7, (March). Bloomington: Phi Delta Kappa, p. 514.

${ }^{174}$ Rose, "Straight Talk About The Public Schools," 164.

${ }^{175}$ Berliner and Biddle, The Manufactured Crisis - Myths, Fraud, and the Attack on America's Public Schools, 215-240.
} 
school. Research shows that students, with encouragement, can make sound gains very early in life and in their school experience. Cetron noted that "Unfortunately, such encouragement is the exception, not the rule" as illustrated by the following statistics:

About 25\% of American children under the age of 6 now live in poverty. $60 \%$ of mothers hold down jobs, nearly twice as many as in the 1960's, and half of those have babies under one year old. They have little time to give their children the support they need: too many lack the skill and inclination. As many as 7 million youngsters, or latchkey children, must fend for themselves while their parents are at work. In the inner city, their role models are the dropouts and drug dealers who infest their neighborhoods. An even more serious disadvantage has befallen the estimated 220,000 to 750,000 homeless children in the United States.

Cetron sees this problem only getting worse. ${ }^{176}$

Analyses of decline in student performance have given little attention to the societal changes which have taken place and ignored the increasing responsibility imposed on schools to address the problems created by social change. Rittenmeyer agreed with Cetron and Lieberman that schools should not be judged on how they are able to deal with social problems, but with educational issues. The increasing rate of children living in poverty, effects of divorce, teen pregnancy, drugs, drinking, crime/weapons in the schools, and teen suicide all impact negatively on the classroom. Although teachers are capable and schools and resources are adequate to the task of education, they cannot be expected to handle also the achievement of racial balance, elimination of poverty, fight drug abuse, prevent pregnancy and the reduction of teen suicide. "Our teachers and principals should be required to address educational issues, not unmet social needs. If we wish to improve the educational performance of our schools, we must first improve the quality of life of our youth. Only then can we fairly evaluate the degree to which our schools

\footnotetext{
${ }^{176}$ Cetron and Davies, American Renaissance, 66.
} 
are fulfilling their educational objectives."177

The drug issue remains high on the list of social problems which have found their way into the schools. Toffler (1990) claims "the problem of drug abuse requires integrated action by many bureaucracies simultaneously: policy, health authorities, the schools, the foreign ministry, banking, transportation and more. But getting all these to act effectively in concert is almost impossible." 178

"The data show that, in spite of the fact that the schools are being asked to take more and more responsibility for preparing students for their place in society, overall our education system is doing a pretty good job. It's time for educators to stop accepting the blame for society's problems." 179

"Schools can easily shift from panacea to scapegoat. If the schools are supposed to solve social problems, and they do not, they present a ready target." 180 Schools "need to become part of an integrated team of governmental and social agencies all directing their unique talents to dealing with the basic problems that must be resolved before we can realize our national goal of educating every child." 181

The schools have not caused these problems, nor can they fix them alone...the schools are but one constituent of society. No one social element can solve all of the problems. All segments

\footnotetext{
${ }^{177}$ Rittenmeyer, “Social Ills Make School Reform Impossible,” 232.

${ }^{178}$ Toffler, Power Shift, 263.

${ }^{179}$ Barber, Straight Talk About America's Public Schools: Dispelling the Myths, 263.

${ }^{180}$ Tyack and Cuban, Tinkering Toward Utopia, A Century of School Reform, 14.

${ }^{181}$ Rose, Straight Talk About the Public Schools, 165.
} 
- business leaders, the clergy, politicians, health-care providers, educators, families, law enforcement officials, and others - must do their part. ${ }^{182}$

"The public schools, for all their faults, remain one of our most stable and effective public institutions - indeed, given the increase in social pathologies in the society, educators have done far better in the last generation than might have been expected." ${ }^{183}$

\section{Outside Competition}

Due to the problems faced by the public schools and the rising affluence of the middle and upper classes, many parents will turn away from public education to private schools, non-profit or for profit, denominational or nondenominational. It has been argued "that the way to regenerate schooling is to create a market system of education in which parents can choose their children's schools, either public or private, and pay the tuition through vouchers funded by taxes." ${ }^{184}$

When discussion turns to the quality of education, it is not uncommon for a friend or neighbor to suggest that the problems of the public schools could be solved by school choice, education vouchers, privatization, home schooling, or some other plan to shift funding and responsibility for education to the private sector. ${ }^{185}$

"Stories of students carrying guns and schools unable to fix leaking ceilings and asbestoslined walls reinforce the common view of public education as too overwhelmed by violence and

\footnotetext{
${ }^{182}$ Barber, Straight Talk About America's Public Schools, 263.

${ }^{183}$ Tyack and Cuban, Tinkering Toward Utopia, A Century of Public School Reform, 38.

${ }^{184}$ Ibid, 8.

${ }^{185}$ Center on National Education Policy. 1996. Do We Still Need Public Schools? Bloomington: Phi Delta
} Kappa, p. 3. 
bureaucracy to provide effective teaching." ${ }^{186}$ Public concerns over "declining finances, poor performance, and conflicts over ultimate purpose and value has made school privatization seem an increasingly reasonable and plausible solution." 187

Lieberman saw public schools, nonprofit private schools, and schools for profit as having important roles in the future. He viewed vouchers as being vehicles to obtain an education where parents best see fit for their children. With the expansion of the lower class population and their general inability to benefit from the voucher system, their students will remain in public schools. Such a scenario only can point to lower standardized test scores which parents look to in selecting educational options for their children.

Lieberman also discussed the fairness issues over vouchers between public and private schools. "The mere fact that private schools may be selective in who they enroll creates an unfair advantage. Private schools may appear to be superior for reasons that have nothing to do with the effectiveness of their teachers or programs." ${ }^{\text {"188 }}$ Nevertheless, the fact remains that public education will receive continued criticism if the gap between public and private school student performance widens.

Under a voucher system, which is usually presented as an expanded form of school choice, "education ceases to be a collective public undertaking and becomes instead a private relationship between each family and its school. Schooling ceases to be part of the public sphere; no longer a

\footnotetext{
${ }^{186}$ Ascher, Fruchter and Berne, Hard Lessons, Public Schools and Privatization, 1.

${ }^{187}$ Ibid, 5.

${ }^{188}$ Lieberman, Public Education: An Autopsy, 57.
} 
public service, it becomes a consumable item."

United States Secretary of Education Richard W. Riley contents that "private school vouchers offer us no public accountability. They are a retreat from the democratic purposes of public education, a way to divert public tax dollars, and they will wind up costing taxpayers a great deal of money." 190 Studies on student achievement among students in Cleveland and New York City who have used vouchers to transfer to other schools have yielded mixed results. ${ }^{191}$ and 192

Lowe and Miner contend that a voucher system would destroy "the few democratic gains made in public education in recent years, worsen inequalities that already permeate education, and block opportunities for meaningful reform." ${ }^{193}$

While an increase in enrollment in private schools would damage the public schools, "the public schools will survive because they represent the only viable means for delivering educational services to this nation's children. A voucher system will not change that." The public schools are not about to be restructured out of existence since there is neither the money nor the public demand to bring such change about. ${ }^{194}$

"The American people are very clear about what they want. They want safe schools, the

${ }^{189}$ Ascher, Fruchter and Berne, Hard Lessons, Public Schools and Privatization, 7.

${ }^{190}$ Riley, Education: The Gateway to America's Future, 8.

${ }^{191}$ Archer, Jeff. 1998. "NYC Voucher Students Post Modest Gains.” Education Week, vol. xviii, no. 10, (November 4). Bethesda: Education Week, p. 3.

${ }^{192}$ Walsh, Mark. 1998. "Vouchers Yield Mixed Results, Report Says.” Education Week, vol. xviii, no. 14, (December 2). Bethesda: Education Week, p. 3.

${ }^{193}$ Lowe, Robert, and Barbara Miner. 1992. False Choices: Why School Vouchers Threaten Our Children's Future. Milwaukee: Rethinking Schools. First Search, ERIC No. ED356283.

${ }^{194}$ Rose, Straight Talk About The Public Schools, 164. 
basics as a sure foundation, more demanding courses that meet high standards, computers into the classroom, good citizenship and classes that teach our young people real life skills and prepare them for college level work. They do not want private school vouchers." 195

“The (United States) Supreme Court announced November 9 that it would not hear the appeal in Jackson v. Benson (Cases No. 98-376). The court voted 8-1 against a ruling of the Wisconsin Supreme Court that upheld the expanded Milwaukee Parental Choice Program.” The state-enacted program provides vouchers to more than six thousand low-income Milwaukee children this year to attend private and religious schools. ${ }^{196}$

To remain competitive, Susan Arisman points out that new schools will have four components that must be addressed: student learning, high expectations, the involvement of a wider community of players, and alternative measures of achievement. ${ }^{197}$

The idea of charter schools has been proposed as a means of creating competition with the public schools. "The charter concept is simple but powerful: sound school choices can be provided to families under the umbrella of public education without micro management by government bureaucracies." 198

Charter schools may be created as new public schools or conversions of existing ones, are nonsectarian, have no admission tests, are responsible to improve student achievement or be closed, have state and local rules and regulations waived, allow

${ }^{195}$ Riley, Education: The Gateway to America's Future, 9.

${ }^{196}$ Walsh, Mark. 1998. “Green Light for School Vouchers?” Education Week, vol. XVIII, no. 12, (November 18). Bethesda: Education Week, p. 1.

${ }^{197}$ Arisman, Susan. 1994. "From Active Teaching to Active Learning," in Educational Innovation: An Agenda to Frame the Future, Charles E. Greenawalt, II., ed. New York: University Press of America, p. 12.

${ }^{198}$ Manno, Bruno V., Chester E. Finn, Jr., Louann A. Bierlein, and Gregg Vanourek. 1998. "How Charter Schools Are Different.” Phi Delta Kappan, vol. 79, no. 7, (March). Bloomington: Phi Delta Kappa, p. 490. 
parents to select the schools, and are provided the same per pupil funding as all other schools including special education, Title 1 and compensatory funds. Various public bodies including state and local school boards, universities, and city governments are permitted to authorize charter schools. ${ }^{199}$

"Despite the enthusiasm of its advocates, privatization has not proved itself a solution to low student achievement or declining school budgets. Moreover, it has not improved accountability, widened parent involvement, or increased equity."200

Interestingly enough, "Most privatization advocates are uninterested in questions of how children learn, or even what good classrooms look like. Not surprisingly, so far those privatizers that do offer descriptions of "break the mold" classrooms have drawn their images from good public schools." 201

\section{The Future of School Reform}

Reform efforts have a common root in the National Commission on Excellence in Education's report A Nation at Risk which advocated more subjects and more time in schools, the setting of high expectations for entrance to colleges and universities, and the allocation of resources necessary to make these reforms happen. This report appeared at a time when American public education was under attack as being responsible for the decline in commerce, industry, science and technology. As the report stated, "If an unfriendly foreign power had attempted to impose upon America the mediocre educational performance that exists today, we

\footnotetext{
${ }^{199}$ Nathan, Joe. 1998. "Heat and Light in the Charter School Movement." Phi Delta Kappan, vol. 79, no. 7, (March). Bloomington, Phi Delta Kappa, p. 500.

${ }^{200}$ Ascher, Fruchter and Berne, Hard Lessons, Public Schools and Privatization, 111.

${ }^{201}$ Ibid, 7.
} 
might well have viewed it as an act of war. As it stands, we have allowed this to happen to ourselves." 202

“The Nation at Risk report, with its emphasis on 'reasserting' high standards, more rigorous graduation requirements, and more rigorous testing, is based, at least in part, on the assumption that the schools have lost their credibility as agents for selecting and sorting the population."203

"A Nation at Risk accomplished its purpose; it jolted people - educators, teachers, parents, students - into taking a hard look at their local schools, and acting on what they saw."204 "By sounding a needed alarm and by articulating sensible goals for improvement, A Nation at Risk helped focus and intensify a vigorous popular movement for reform of American education."205

Reacting to the deteriorating condition of American public education as outlined in that report, then-President Bush convened a summit meeting with his cabinet which was attended by forty-nine governors at Charlottesville, Virginia, in 1989. His intent was to address the crisis in K-12 education through the design of a set of national standards for education. Influential in the design of the standards at that time was then-governor of Arkansas, Bill Clinton. During the development of the goals it became clear that a major failing of K-12 education was caused by unclear expectations of what a student should know or be able to do. Those countries which

\footnotetext{
${ }^{202}$ National Commission on Excellence in Education, A Nation at Risk: The Imperative for Educational Reform, 5.

${ }^{203}$ Schlechty, Schools for the $211^{\text {st }}$ Century, 7.

${ }^{204}$ Cetron and Gayle, Educational Renaissance, Our Schools at the Turn of the Century, 4.

${ }^{205}$ Bennett, William J. 1988. American Education, Making It Work. Washington: United States Department of Education, p. 1.
} 
were considered America's trading and economic rivals had much clearer criteria for student outcomes. The eventual product of the summit was a set of national goals for education known as America 2000. Thomas O'Brien identified three trends from which the reform movement has grown - "the emergence of the state as the primary revenue provider, the new emphasis on excellence (replacing the equity efforts of the 1970s), and the general perception of decline." These three trends gave governors, state legislators, business groups and others who controlled educational spending potent political issues upon which to redirect American education toward reform to increase state financing of public education. ${ }^{206}$

\section{Reform Under Clinton}

Upon assuming the presidency from George Bush, and after making some minor modifications, President Clinton transformed America 2000 into Goals 2000. His original thinking on the need to reform schools was based in part on the ideas of John Goodlad in his book A Place Called School. As Clinton explained, Goodlad identified educational problems in need of reform as control of large numbers of students in small space, the consumption of time dealing with management problems which would be devoted to developing innovative programs, limited time-on-task, the dependence on lecture as a primary teaching tool, lack of written work required, teacher isolationism reducing collaboration, lack of adequate planning time for complex learning activities, and the lack of higher order thinking skills which only appear in courses reserved for college-bound students. By emphasizing that more students would learn what only a few learn

\footnotetext{
${ }^{206}$ O'Brien, Thomas V. 1994. "Educational Reform Movements Among the States in the Last 10 Years," in Educational Innovation: An Agenda to Frame the Future, Charles E. Greenawalt, II, ed. New York: University Press of America, p. 35.
} 
now, Clinton wanted to restructure schools in order to clarify and simplify the goals of education.

To him, restructuring advocated changes in instructional delivery, better use of time, creating conducive learning atmospheres, integrating technology into the curriculum, managing more effectively, decentralized districts, and site-based management with a new definition of teaching. ${ }^{207}$

Greenawalt did not agree with Clinton that school reforms are necessary merely for the betterment of education, but felt that they are really large-scale attempts to deal with societal problems that seem incurable on other economic, political, and social levels.

Each effort to create new educational paradigms is a specific attempt to deal with an American society that many believe has gone awry. The accelerated deterioration of our values; disruptions in our economy; challenges to our political system; increases of poverty among the young; reductions in community safety; increases in drug usage in some segments of society; the decreases in the presence of the nuclear family; and many more, are then seen as elements driving the school reform movement. ${ }^{208}$

Tom Loveless viewed Goals 2000 as a conversation between governments - federal, state and local. Through what he calls "trickle down school reform," each level wants the lower one to do better down to the principal and teacher. To Loveless, Goals 2000 ignored the teachers, students and parents who sit at the center of school reform as they have had little input into the decision-making process. "To the degree that teachers are out of the policy loop in designing and adopting school reforms, it is not surprising if they drag their feet in implementing them."209

\footnotetext{
${ }^{207}$ Clinton, Bill. 1990. "Schools Must Be Restructured,” in America's Future: Opposing Viewpoints, William Dudley and Bonnie Szumski, eds. San Diego: Greenhaven Press, pp. 181-182.

${ }^{208}$ Greenawalt, Educational Innovation, ix.

${ }^{209}$ Tyack and Cuban, Tinkering Toward Utopia: A Century of Public School Reform, 135.
} 
Loveless also forecasted that the federal and state governments will become more powerful. Since school finances are dependent on federal and state dollars, the federal government is expected to fund through the states the programs that will address national problems. Through their regulations, they will control delivery of programs and services at the local level, thus constraining local autonomy. ${ }^{210}$

Steven Arons agreed that the federal government will exercise more control through Goals 2000 and indicated that only one argument for Goals 2000 exists - to reduce the inequities in school that have affected so much of our population. He noted that the law has one fatal flaw in that it will lead to the creation of a national curriculum as a means of reaching its student achievement and citizenship goals. Arons also felt that the curriculum provisions of Goals 2000 should be repealed and be replaced by a ten year program through which every teacher in the United States would receive two summer training institutes in their selected academic fields to improve their competencies. ${ }^{211}$ Kirst and Guthrie saw the new role of the federal government as becoming standards-oriented. This can be seen through the recent reauthorization of Title 1 with its emphasis on high quality standards for all students. ${ }^{212}$

\section{Barriers to Reform}

As the concepts of school reform and restructuring have evolved, certain problems have arisen which have impeded implementation such as the lack of direction and strong leadership in

\footnotetext{
${ }^{210}$ Loveless, “The Politics of National Standards," 52.

${ }^{211}$ Arons, Steven. 1994. “The Threat to Freedom in Goals 2000," in The Future of Education: Perspectives on National Standards in America, Nina Cobb, ed. New York: College Entrance Examination Board, p. 58.

${ }^{212}$ Kirst and Guthrie, “Goals 2000,” 158.
} 
communities, poor communication, complacency with standardized test scores, bureaucratic constraints discouraging experimentation and creativity, and the lack of consistent support from both outside and inside the system. President Clinton continues to insist that restructuring is necessary to allow more control by individual schools and more involvement by business and parents and believes schools must teach children problem-solving and critical thinking skills. ${ }^{213}$

Susan Arisman saw the barriers to reform as including its complexity, the demands placed upon teachers, a lack of infrastructure to support reform, changes in professional development, and the lack of caring for children that is rampant in some parts of this nation. "Television is the great care giver of the decade. Children are pacified with consumer goods, television and junk food." Arisman also noted that "reform takes courage"214 and stated that

Although there are other components to educational reform, such as governance, interdisciplinary courses, class size, choice, and scheduling, to mention a few...without changing ideas about learning, without creating communities in which learning is respected, without setting high expectations for all students, without opening education to others who have a stake, especially in the lives of their own children, and without changing the assessment systems, little will be accomplished. $^{215}$

O'Brien indicated that "There are at least 3 critical variables that will determine the fate of restructuring - time, money, and opportunities for classroom teachers."216

\footnotetext{
${ }^{213}$ Clinton, “Schools Must Be Restructured,” 158.

${ }^{214}$ Arisman, "From Active Teaching to Active Learning," 27.

${ }^{215}$ Ibid., 22.

${ }^{216}$ O’Brien, “Educational Reform Movements,” 51.
} 


\section{The Failure of School Reform}

As the initial reports on the success or failure of school reform emerged, opinions quickly formed about its effectiveness. Phillip C. Schlechty noted that "One of the greatest barriers to school reform is the lack of a clear and compelling vision." ${ }^{217}$ Charles E. Finn, Jr., felt that restructuring had failed because of its superficiality. "The failure of reform efforts is because we have not worked with the final product in mind - we have focused on resources, processes, organizational arrangements, and employees without regard to the final product." Finn stated

We have ignored the basic premise of educational research and common sense people tend to learn that which they study, and to learn it in rough proportion to the amount of time they spend at the task. To fix the situation, we need to define our product, set clear and high expectations and performance standards, and allocate adequate instructional time to meet them.

Finn argued that we need to focus on skills, knowledge, habits and attitudes that young people should possess upon emerging from school into adulthood. ${ }^{218}$

Rittenmeyer felt that for reforms to succeed, educators need to broaden their view of educational problems and understand the changes society has experienced, determine whether it is proper for schools to carry the burden of responsibility for social ills which are not the result of actions or inactions by the schools, determine whether schools are the best place to address such social problems, and then give them additional resources. "Critics ignore the fact that we have required our schools to become the largest and most comprehensive social service delivery system

\footnotetext{
${ }^{217}$ Schlechty, Schools for the $21{ }^{\text {st }}$ Century, 137.

${ }^{218}$ Finn, Jr., Charles E. 1990. "Restructuring Will Not Improve Schools," in America's Future: Opposing Viewpoints, William Dudley and Bonnie Szumski, eds. San Diego: Greenhaven Press, pp. 185-186.
} 
in the world." ${ }^{219}$ Rittenmeyer's criticism was an attempt to separate the responsibilities of education as teaching and learning from the country's social ills. Until the two can be isolated and dealt with effectively, and until society tries to improve children's lives, children will be denied their means of achieving their full potential, and structural reform cannot happen.

\section{The Continued Need To Reform}

The supporters of educational reform view reform itself as necessary to resolve three concerns. First, at a time of increasing international economic competition, the productivity of the United States economy and workforce is declining. Second, demographic shifts in population are altering characteristics of students at all levels, with more racial and ethnic minorities. Third, skepticism is increasing about the capacity of traditional public and private institutions to respond to declining productivity and demographic change. ${ }^{220}$

Finn noted that Albert Shanker coined the term "Second School Reform" which, he felt had some good ideas - cut back central office bureaucracies, recognize individual schools as essential units of educational activity, encourage schools to distinguish themselves from one another, and allow families to choose those schools that will best serve their children. ${ }^{221}$

\section{School Reform in West Virginia}

Since the appearance of $A$ Nation at Risk in 1983, West Virginia public schools also have made significant progress in solving their educational problems. West Virginia's system of public

\footnotetext{
${ }^{219}$ Rittenmeyer, “Social Ills,” 232.

${ }^{220}$ Clinton, "Schools Must Be Restructured," 179.

${ }^{221}$ Finn, “Restructuring Will Not Improve Schools,” 188.
} 
schools, along with that of Connecticut, was recently rated to be among the nation's best. The ratings were based on each state's efforts to raise student achievement, set high standards for all children and make assessments aligned with those standards; prepare teachers with the knowledge and skills to teach those standards; create schools and classrooms that are conducive to teaching and learning, and distribute adequate funds for schools in an equitable manner. ${ }^{222}$

During the last fifteen years, West Virginia has been given credit for having raised teachers' salaries and for spending more that $\$ 500$ million to build and renovate schools and wire them for computers and telecommunications. A system of county and school accreditation has been developed, new Instructional Goals and Objectives have been designed, and a new statecounty testing program is in place. As a result, since 1990, students' scores have already crept upward on National Assessment of Educational Progress tests. ${ }^{223}$

But last April, a state court judge told school leaders and state lawmakers that, despite their good work, the system had not come far enough. Retired Cabell County Circuit Judge Dan Robinson, who had been called in to update a landmark 1982 school finance ruling against the state, found that the system still violated the equal-protection and education clauses of West Virginia's constitution. He gave the legislature one year to draft a plan to equalize funding between poor and wellto-do school districts. The ruling raised a new challenge for the Mountain State at a time when school leaders were hitting a few potholes on the road to school reform. ${ }^{224}$

West Virginia also has experienced new school construction, consolidation, and regionalization. According to the West Virginia School Building Authority, there have been 254

\footnotetext{
${ }^{222}$ Education Week. 1998. “Quality Counts ‘98,” vol. XVII, no. 17, (January 8). Bethesda, Education Week, p. 76.

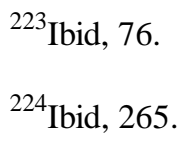


school closures since 1989 as a result of consolidation, declining enrollment or replacement of

outdated facilities.

Enrollment in West Virginia schools dropped from 401,882 in 1970 to 323,762 in 1990 , then even further to 301,314 during the 1997-98 school year.....Twentyeight counties have been through school closures or consolidation projects since 1989. Of West Virginia's 55 counties, 27 have a single consolidated high school. Several other school districts are considering consolidation. ${ }^{225}$

\section{Demographics Changes and the Educational Environment}

Although the total population in the United States has grown steadily since the early

1970s, West Virginia's total population has grown steadily only during the 1990s. ${ }^{226}$

After uninterrupted growth from 1870 through 1950, West Virginia's population level began fluctuating. It increased by 104,000 during the 1940s, declined by 145,000 in the 1950s, lost another 116,000 in the 1960s, increased 205,000 in the 1970s, and decreased 156,000 in the 1980s. Most counties followed the state trend. Only three counties lost population in the 1970s, and only ten counties gained population in the 1980 s. $^{227}$

The decline in population between 1980 and 1990 represented a loss of 8.0 percent. ${ }^{228}$ At the same time, the population in the United States was in excess of 248 million and had grown by 9.8 percent. $^{229}$ Based on estimates, West Virginia's 1995 total population stood at about the same

${ }^{225}$ Coleman, Randy. 1998. “Consolidation Foes Say Bigger Isn't Better.” Clarksburg Exponent-Telegram, vol. 72, no. 47, (August 23). Clarksburg, WV: Clarksburg Publishing Company, p. B4.

${ }^{226}$ Bureau of Business Research. 1992. North Central West Virginia Economic Impact Analysis: Supply and Demand Inventory. Morgantown: West Virginia University, (March), p. A-1.

1.

${ }^{227}$ Regional Research Institute, West Virginia Population Projections by County, Age, and Sex - 1990-2020,

${ }^{228}$ Center for Economic Research. 1992. State of the Region Today and 2000. Morgantown: West Virginia University, p. 16.

${ }^{229}$ Ibid., 16. 
level as in 1974. The 1995 estimate of population in West Virginia was 1,825,256, up from 1,793,477 at the 1990 census. Based on the 1995 estimates, West Virginia ranked 35th in the nation in total population. ${ }^{230}$ The median age at the 1990 census was 35.4 years. ${ }^{231}$

The U. S. Census Bureau estimated for the year July 1, 1997, through July 1, 1998, that populations declined in Pennsylvania, North Dakota, West Virginia and the District of Columbia. "West Virginia was the first state in recent years to have more deaths, 19,736, than births, 19,281."232

Other West Virginia population characteristics showed females outnumbering males 52 percent to 48 percent, respectively. The state's two largest ethnic groups are white (96.2 percent) and black (3.1 percent). The number of divorced persons was 8.1 percent of the population, and 1.4 percent were separated. ${ }^{233}$ The 1990 census indicated that 63.9 percent of West Virginia's population lived in rural areas, and 19.7 percent of the population was below the national poverty rate. In 1993, the percent of population below the national poverty level had increased to 21.6. The 1990 census also indicated that the 25 to 44 year age group was the largest in the state, followed by the 45 to 64 year age group. ${ }^{234}$

The age composition of the state population changed markedly. There were fewer

\footnotetext{
${ }^{230}$ Bureau of Business and Economic Research. 1997. County Data Profile 1997-1998 - United States. Morgantown: West Virginia University, p. 4.

${ }^{231}$ Bureau of Business and Economic Research. 1997. County Data Profile 1997-1998 - West Virginia. Morgantown: West Virginia University, p. 35.

${ }^{232}$ Schmid, Randolph. 1998. “West Virginia Population Declines.” Clarksburg Exponent-Telegram, vol. 89, no. 77, (December 31). Clarksburg, WV: Clarksburg Publishing Company, p. A8.

${ }^{233}$ Center for Economic Research. 1992. West Virginia 1990 Census Profile Series. Morgantown: West Virginia University.

${ }^{234}$ Bureau of Business and Economic Research, County Data Profile 1997-1998 - West Virginia, 9, 11, 35.
} 
young people and more elderly. Comparing 1990 to 1980, only those age groups $65+$ and 35 through 49 had more people. Two baby-boomer cohorts, born between 1946 and 1955, caused an increase of 64,000 in the population aged 35 through 44 . The cohorts born before 1926 and now $65+$ increased the elderly population by about 30,000. On the other hand, every five year age group from 04 through 25-29 had 22,000 to 53,000 fewer people in 1990 than in 1980.

These changes in the present population composition will affect West Virginia's future population. Fewer people in the child-bearing ages will lead initially to fewer children and then, as those children become adults, to still fewer people in child-bearing ages and then, again fewer children. The out-migration that occurred during the 1980s will limit West Virginia's future population growth in this way...Consequently, fewer children will be born in West Virginia in the 1990s. Fewer children in both the 1980s and 1990s means fewer young adults and children between 2000 and $2020 .^{235}$

Population projections estimated the state would increase by 0.59 percent between 1990

and 2020. "West Virginia's population decline has almost bottomed out. The population level

will be stable over the next 30 years at the present level of 1.8 million people. West Virginia will

lose 7,000 in the 1990s but will gain back 17,000 in the following two decades. ${ }^{236}$

Comparing 1990 and 2020, West Virginia will have fewer people in every age group below the age of 44 . Increases in most other age groups balance this decrease. There will be 81,000 fewer people in the school and preschool ages, 0 19 , and 76,000 fewer people in the young labor force ages, 20-44, but there will be 123,000 more people in the older labor force ages, 45-64, and 44,000 more people in the elderly groups, 65+. These changes in population levels by age have important implications for housing conditions, employment prospects, school enrollments and consolidations, health service provision and the markets for many goods and services. ${ }^{237}$

The aging population in relation to public education has been addressed by Dychtwald.

\footnotetext{
2.

${ }^{236}$ Ibid, 3.

${ }^{237}$ Ibid.
}

${ }^{235}$ Regional Research Institute, West Virginia Population Projections by County, Age, and Sex - 1990-2020, 
Some seniors have begun to challenge the need to pay taxes for schools and have organized to defeat school-bond issues. Local budgets are becoming battlegrounds between such competing needs as childhood education and senior housing or child care and adult recreation. The retirees argue that since they have no school-age children, they shouldn't have to be encumbered by school taxes. Angry opponents have argued that a convenient "amnesia" has allowed these elders to forget that for the great majority of them, their own education and that of their children and grandchildren was free and public, paid for by taxes. ${ }^{238}$

The aging population is projected to impact West Virginia's public education system through an acceleration of teacher retirements. "Based on current data, West Virginia is positioned to lose through retirements, our most experienced, and for the most part, most highly educated teachers." By 2010, there will be a total of 11,587 teachers eligible to retire in West Virginia, or about 52 percent of the 22,368 teachers employed in 1996-97. It is projected that by 2010 approximately 6,921.04 (FTE basis) teachers, or 60 percent of those eligible, will actually retire. This rate of retirement is 2.6 times the rate experienced during the previous twelve years. "This loss of personnel has the potential to adversely affect the delivery of a quality education for many students." 239

Total employment has risen since the late 1970's in the United States and has grown at a faster rate than that of West Virginia, which has only grown since 1983. Personal income and average earnings per job in West Virginia also lag behind those of the United States. Total personal income (TPI) in West Virginia ranked 37th in the United States in 1995, down from 35th in 1985. Between 1985-1995, average annual growth of TPI was 4.8 percent in West Virginia

\footnotetext{
${ }^{238}$ Dychtwald and Flower, Age Wave, The Challenges and Opportunities of an Aging America, 81-82.

${ }^{239}$ Margolin, Arnie, and Linda Crone-Koshel. 1998. Tomorrow's Teachers, The Future Supply and Demand for West Virginia Teachers: 1998-2010. Charleston, WV: The Education Alliance, pp. 1-3.
} 
and 5.2 percent nationally. During that same time period, per capita personal income increased, but the state remained ranked at 50th in personal income in the country. As of 1995, services was the leading employment sector followed by retail trade, government and manufacturing in both the United States and West Virginia. Unemployment was varied across West Virginia averaging 6.9 percent as compared to the 4.9 percent national average. Highest rates of unemployment were found in areas along the West Virginia - Kentucky border, with the lowest rates generally found in the northern and eastern panhandles of West Virginia. These same areas also showed a corresponding relationship in the percent of population below poverty (21.6 percent state-wide in 1993) and in the percent of change in population between 1990 - 1996. Job growth averaged 4.5 percent between 1990 - 1995 in West Virginia. ${ }^{240}$

Job growth has been decelerating in West Virginia since 1994. The number of jobs in the state has risen by an average of 1.4 percent from January, 1995 to August, 1998. Nationally, the job rate has increased by 2.3 percent per year. "One of West Virginia's biggest problems is it has a low share of college graduates in the population which makes it hard to attract firms to the state that need college graduates if you don't have any."241

The number of families eligible for free and reduced-priced school meals may be used as a gauge of poverty.

One-half of West Virginia's children receive free or reduced-priced meals. This is an undercount because research tells us that many children in the upper grades who are eligible do not apply. School meals mean the difference between nutrition and malnutrition for thousands of West Virginia children. The scope of poverty

\footnotetext{
${ }^{240}$ Bureau of Business and Economic Research, 1997. County Data Profile 1997-1998 - West Virginia, 9, 12.

${ }^{241}$ Leaken, Paul. 1998. “Outlook Fair for State Economy.” Clarksburg Exponent-Telegram, vol. 89, no. 142, (November 14). Clarksburg, WV: Clarksburg Publishing Company, p. A8.
} 
that it reflects is staggering. ${ }^{242}$

During the 1980 s, median family income (in 1990 dollars) declined 3.9 percent to $\$ 25,602.00$, the percent of children in poverty increased by 40 percent to 26.2 percent of all children, and the percent of children in single-parent families increased by 45.4 percent to 17.4 percent of all families. Unemployment declined during the period by 16 percent to 7.9 percent, but the total jobs in high-paying industries also declined by 18.9 percent while the total jobs in lowpaying industries increased by 42.3 percent. State-wide improvements were made during the 1980s as evidenced by reductions in the infant mortality rate, child death rate, teen birth rate, high school dropout rate, teen violent death rate, and in the percent of births to mothers with less than a 12 th grade education. ${ }^{243}$

The rate of teen pregnancy has moderated in West Virginia. In 1995, the teen pregnancy rate was 52.9 births per 1,000 teens, down from 68.9 per 1,000 in 1980. Today

one out of every 19 teens ages 15-19 has a baby...Teens are ill equipped to be parents. Teens who are pregnant need high quality prenatal care, and once they begin parenting, educational and support services are essential. Preventing teen pregnancy requires comprehensive efforts including education, access to reproductive health services and motivation for current success, and hope for future self-sufficiency. ${ }^{244}$

The myriad of problems with which public schools must contend raises serious questions about the future of public education. Educational leaders need to have some idea of what might

\footnotetext{
${ }^{242}$ West Virginia Kids Count Fund. 1997. West Virginia Kids Count Data Book. Charleston, WV: West Virginia Kids Count Fund, p. 11.

${ }^{243}$ Ibid., 16.

${ }^{244}$ Ibid, 11.
} 
happen in the future so that they can plan for change rather than react to it. The Delphi technique is a forecasting tool that provides a means by which predictions about the future can be made.

\section{The Delphi Technique}

Educational leaders "consistently scan their external environment for trends, so they will be able to project these trends and develop intervention strategies that will assist in developing and maintaining a healthy organization." 245

Floyd L. Stead, in his 1975 doctoral dissertation, wrote

One of the most recent forecasting tools in educational planning and decisionmaking is the Delphi technique. The Delphi technique was originally developed by the RAND Corporation for obtaining greater consensus among experts about urgent defense problems without face-to-face discussion. A number of studies employing the Delphi technique have been performed by the RAND Corporation. One example was its use in conducting an extensive survey in forecasting longrange developments, some as far as fifty years into the future, in such areas as scientific breakthroughs, population growth, automation, space progress, probability, and prevention of war and future weapons systems. ${ }^{246}$

Delphi studies use a panel of experts who are identified as being knowledgeable in the areas being studied. The experts are asked a series of questions about the likelihood of certain events occurring. The answers to the questions are returned to the investigators for their review and refinement of the original set of questions. This process is repeated at least three times between the investigators and the original experts as a means of clarifying and narrowing the focus of the responses so that a more precise set of conclusions can be drawn about what the

\footnotetext{
${ }^{245}$ Herman, J. J., and J. L. Herman quoted in Webber, Charles F. 1995. “School Board Members' Perceptions of the Future: Patterns and Implications." Washington: United States Department of Education, Office of Educational Research and Improvement (OERI). ERIC Document Reproduction Service, \#383110, p. 5.

${ }^{246}$ Stead, An Application of the Delphi Method of Forecasting to Nursing Education Planning in West Virginia, 15.
} 
experts think. Since face-to-face interaction is not a requirement, the Delphi technique could be used with groups that would not ordinarily meet together. If used with the uninformed, however, the results of a Delphi study will likely be unsatisfactory. ${ }^{247}$

Results of Delphi investigations may be developed into a scenario for use by practitioners and planners.

A scenario is developed by studying all possible information about a problem and projecting a broad range of trends, their likelihood of occurrence, and the degree of impact on the organization under study if the trends did occur. Scenarios make us aware of potential pitfalls of negative events, they provide an opportunity to conceptualize future successes, both as individuals and as organizations, allow for the analysis of a variety of plans, and encourage imagination, creativity and the development of knowledge about broad trends and ideas. ${ }^{248}$

The advantages to the Delphi technique include: (1) opportunities for large numbers of people to participate; (2) anonymity for participants which makes the contribution of ideas a safe activity; (3) free of social pressures, personality influences, and dominance by individuals; (4) opportunities for participants to reconsider their opinions; (5) information sharing and reasoning among participants; (6) independent thinking and gradual formulation; (7) a varied and wellselected respondent panel; (8) consensus among hostile groups, and (9) inexpensive. ${ }^{249}, 250$ The Delphi process also has the advantage of seeing what experts who have no affinity with the

${ }^{247}$ Flinchbaugh, The 21st Century Board of Education, 169.

${ }^{248}$ Hoyle, Leadership and Futuring, Making Visions Happen, 48.

${ }^{249}$ Webber, Charles F. 1995. "School Board Members' Perceptions of the Future: Patterns and Implications." Washington: United States Department of Education, Office of Educational Research and Improvement (OERI). ERIC Document Reproduction Service, Accession Number ED383110, p. 5. Virginia, 7.

${ }^{250}$ Stead, An Application of the Delphi Method of Forecasting to Nursing Education Planning in West 
organization have to say about the issues, making the study more objective. ${ }^{251}$

Among the disadvantages of the Delphi technique are the large amounts of time required to conduct several rounds, the complexity of data analyses, the difficulty of maintaining participant enthusiasm throughout the process, and the problem of keeping statements value free and clearly defined."252

\section{Delphi Studies in Education}

The Delphi technique has been used to assess the future of education through the use of various educational panels. Scannel used the Delphi method to obtain consensus among educational, lay, and political groups on opinions concerning the importance of the skills developed in the professional courses included in teacher education programs in Kansas. In addition, Scannel examined the relative willingness of the various subgroups to change their opinions when informed of the total group consensus regarding the initial ratings of teacher competencies. He also studied the value of the Delphi technique in attempts to effect consensus among different groups and individuals. Scannel found that competencies related to teacher classroom behavior were rated highly, while the value of history and philosophy in teacher education programs were rated low. The teacher group changed their responses least often from their initial ratings, while professors and administrators changed most frequently. ${ }^{253}$

Several Delphi studies have been conducted which have assessed various aspects of

\footnotetext{
${ }^{251}$ Flinchbaugh, The 21st Century Board of Education, 170.

${ }^{252}$ Webber, School Board Members' Perceptions of the Future: Patterns and Implications, 5.

${ }^{253}$ Scannel, Dale P. 1972. “The Use of the Delphi Technique to Gain Consensus of the Professional Education Components of Teacher Certification Requirements in Kansas. Final Report.” Washington: United States Department of Education, (OERI), (August). ERIC Document Reproduction Service, Accession Number ED072025.
} 
superintendents and school boards. Stokes conducted a study to determine the guidelines for evaluating school boards and school board members in South Carolina which served as the basis for the development of a self-evaluation instrument in that state. ${ }^{254}$

Rosenberger used the Delphi to determine the knowledge, skills, and attitudes essential for an individual school board member serving in Texas to be effective. Results of this study yielded an extensive task list which gave evidence to the complexity of the role of a school board member. $^{255}$

Webber attempted to predict future educational concerns from a sample of Canadian school board members using a three-round, modified Delphi technique. In this study, he identified three specific purposes in conducting his research which he felt were essential if school board members were to be better able to work cooperatively with other educational stakeholders. Webber attempted to identify (1) the educational concerns, in order of priority, that school board members believed they would be addressing in the future, (2) the themes among those priorities, and (3) the perceptions that school board members have of their future responsibilities. Webber concluded that education will become an increasingly politicized field because of the large number of demands placed on school board members, their unwillingness to relinquish power, and financial concerns. ${ }^{256}$

\footnotetext{
${ }^{254}$ Stokes, Ernest W. 1981. "Establishing Guidelines for the Evaluation of School Boards and School Board Members in South Carolina School Districts.” Columbia: University of South Carolina. First Search, Dissertation Abstracts Online, Accession No. AAG8416368.

${ }^{255}$ Rosenberger, Michal Larraine. 1993. “The Role Acquisition Process of a Local School Board Member in Texas." Austin: The University of Texas at Austin. First Search, Dissertation Abstracts Online, Accession No. AAG9323540.

${ }^{256}$ Webber, School Board Members' Perceptions of the Future: Patterns and Implications.
} 
Using the same general technique, Webber conducted another modified Delphi study to obtain the educational concerns of school superintendents. The study was conducted to inform stakeholders about educational trends. The superintendents identified 70 issues which were of concern to them. Their top priorities focused on the areas of declining financial resources and support with which to run their school systems and a lack of planning for the future. Areas of low concern included school violence, vandalism and racism. "Respondents also assigned relatively low priority ratings to teacher burnout and teacher work overload, which indicates the potential for conflict with teachers." Webber received a high response rate (83 percent) which "may indicate that superintendents want to be involved in the professional dialogue."257

Development of a model for superintendent selection in Texas was the subject of a Delphi study conducted in 1992. Results of the Delphi were combined with data from a literature review on superintendent selection, personnel selection strategies, and characteristics of effective leaders to form a model to be used by school board members when selecting superintendents. ${ }^{258}$

Dulaney used the Delphi technique to study the impact of exposing the lay citizenry to future-oriented information for the purpose of sensitizing them about future educational needs. Although he was most concerned about how future-oriented information would alter the perceptions of citizens about the curricular needs of secondary education, he also was interested in determining what influence the Delphi technique might have on altering opinions of three panel

\footnotetext{
${ }^{257}$ Webber, Charles F. 1995. “A Profile of the School Superintendency: Issues and Perceptions.” Washington: United States Department of Education, Office of Educational Research and Improvement (OERI). ERIC Document Reproduction Service, Accession Number ED383111, p.1.

${ }^{258}$ Jones, Mary Sue McClelland. 1992. "A Model for the Selection of Superintendents by School Board Members in Texas.” Lubbock: Texas Tech University. First Search, Dissertation Abstracts Online, Accession No. AAG9325758.
} 
groups. Dulaney concluded that the level of training and degree of expertise have an impact upon the consensus of lay citizenry on public education issues, and those with higher levels of training and degree are less influenced by their cohorts in a Delphi study than those with less training or information. ${ }^{259}$

Delphi has been used to study various aspects of the education reform movement. A study conducted by the Network of Effective Schools used Delphi to identify eleven of the most needed reforms in American education. These included: acceptance of the idea that all children can learn; schools need to plan, budget, staff and evaluate based on student learning outcomes; schools must have quality leadership with a sound sense of mission; schools must address both excellence and equity; a commitment to excellence must exist among the school board, staff and community; there must be a clear philosophy, mission and goals for public education; schools must improve staff development; schools must improve the knowledge and application of basic reading, writing and math by the time students reach grade six, and must focus on what students should learn, with emphasis on higher-order thinking skills; assessment and diagnosis must be linked, and schools must implement leadership effectiveness programs. The members of the Delphi study group concluded that schools, if implementing these needed reforms, could achieve higher student achievement, reduce their dropout rate, increase attendance, reduce discipline problems, and improve student attitudes about school. ${ }^{260}$

Olson used the Delphi technique to determine what school district reorganization would

\footnotetext{
${ }^{259}$ Dulaney, Jack C. 1980. “The Impact of Future-Oriented Information on Predicting Curricular Needs in Public Schools.” Morgantown: West Virginia University. First Search, Dissertation Abstracts Online, Accession No. AAG8029271.

${ }^{260}$ Network for Effective Schools. 1987. "Expecting the Best: Effective Public Education for All Students. A Report on the Findings of a Major School Reform Study.” First Search, ERIC Accession No. ED282950.
} 
occur in Minnesota between 1992 and 1997, and what the role of the Minnesota School Boards Association would have on policy related to reorganization. Olson found that reorganization would take place in a number of ways, that small districts would be combined with neighboring districts, and that such reorganization decisions should be made at the local level and not forced from mandates. ${ }^{261}$

Ewing used eight groups of experts in his Delphi study to determine the likely and desirable future outcomes of a school improvement program in the state of Missouri. His study compared school districts in which the program had been piloted with non-piloted school districts. Ewing found that responses from panels in piloted school districts had higher degrees of likelihood and desirability than did non-piloted district panels. ${ }^{262}$

Site-based management was studied by Lutz and Iden in 1994. Their Delphi study examined how public school districts in Texas "might effect mandated governance changes through site-based decision making, and examined the influence those changes might have on public participation in educational policy decisions." They found that "the domains of goal setting, staffing, and school organization will offer constituents the greatest opportunity for influencing education policy," and that "participants perceived the site-based decision making offered increased opportunities for citizen participation at the school site; however, they saw

\footnotetext{
${ }^{261}$ Olson, Jeffrey J. 1993. "The Future of School District Reorganization in the State of Minnesota." Minneapolis: University of Minnesota. First Search, Dissertation Abstracts Online, Accession No. AAG9328373.

${ }^{262}$ Ewing, Larry E. 1990. "Perceptions of School Administrators and School Officials Regarding Proposed Changes in Missouri's Classification and Evaluation Program." Columbia: University of Missouri. First Search, Dissertation Abstracts Online, Accession No. AAG9109334.
} 
conflict as inevitable.",263

Several Delphi studies have addressed the future of public education. Jones, in 1984, attempted to predict what schooling would be like in Pennsylvania in the year 2000. Her study used a panel of approximately two hundred experts who were provided a list of twenty issues that might impact education in the future. The intent of the study was to reach consensus on the probability of occurrence of each issue and its impact in the year 2000, and to determine the current (1984) level of involvement with each issue. ${ }^{264}$

O’Donnell used the Delphi technique "to survey the attitudes of a representative group of professionals toward developments in the curriculum, the design of instructional materials, and the use of new technology by classroom teachers at the kindergarten through ninth grade levels." The study identified concerns from the participants over equal access to technology in the future, and also showed mixed enthusiasm about the growth of educational technology. ${ }^{265}$

Using a panel of fifty-five experts, Uchida, Cetron and McKenzie conducted a Delphi study to determine what students would need to know, what they should able to do, and what behaviors they would need to exhibit to succeed in the 21 st century. Knowledge of math, logic, and reasoning skills; interpersonal skills including speaking, listening and teaming; information accessing and processing skills; writing skills to effectively communicate; American history and

\footnotetext{
${ }^{263}$ Lutz, Frank W., and Robert M. Iden. 1994. “The Political Effects of Site-Based Decision Making on Local School Governance in the State of Texas." Washington: United States Department of Education, Office of Educational Research and Improvement (OERI). ERIC Document Reproduction Service, Accession No. ED378636, p. 1.

${ }^{264}$ Jones, Rita S. 1984. "Schooling for the 21st Century: A Delphi Study of Future Issues in Education as Identified by Educational Planners." Philadelphia: University of Pennsylvania. First Search, Dissertation Abstracts Online, Accession No. AAG8416368.

${ }^{265}$ O’Donnell, Peggy. 1988. "Preparing Schools for the Year 2000. The Impact of Technology on America's Classrooms in the Decade Ahead." Washington: United States Department of Education, Office of Educational Research and Improvement (OERI). ERIC Document Reproduction Service, Accession No. ED302223.
} 
government, a scientific knowledge base; history of the world and world affairs; multicultural understanding, and knowledge of foreign languages and world geography were all identified as critical things students should know.

Essential skills included oral and written communication; critical thinking, reasoning and problem-solving skills; self-discipline; computer and other technology usage; interpersonal relations; adaptability and flexibility; conflict resolution and negotiation; research, and multilingual and comprehensive reading and understanding.

Critical behaviors included honesty and integrity; a good work ethic; an appreciation of diversity; ability to team; acceptance of responsibility; respect for others; commitment to family life, personal life and community; pride in citizenship; conflict resolution; a recognition and respect for educators, and life-long learning. ${ }^{266}$

Other Delphi studies have been conducted involving the future role of school psychologists in Pennsylvania ${ }^{267}$, instructionally effective schools in relation to the education of poor children ${ }^{268}$, perceptions of staff development and curriculum services ${ }^{269}$, and establishing

${ }^{266}$ Uchida, Cetron and McKenzie, Preparing Students for the 21 st Century, 6-26.

${ }^{267}$ O'Shell, Wallace D. 1986. “A Delphi Study of the Future Activities of the School Psychologist as Perceived by Superintendents, School Board Members, School Psychologists and Trainers of School Psychologists." Pittsburgh: University of Pittsburgh. First Search, Dissertation Abstracts Online, Accession No. AAG8620307.

${ }^{268}$ Mann, Dale, and Judith Lawrence. 1984. "A Delphi Analysis of the Instructionally Effective School." Washington: United States Department of Education, Office of Educational Research and Improvement (OERI). ERIC Document Reproduction Service, Accession No. ED249580.

${ }^{269}$ Padro, Susan. 1978. "Survey of Staff Development and Curriculum Services for Quality Education, Part II - Delphi Studies on Curriculum Services and Quality Education.” Washington: United States Department of Education, Office of Educational Research and Improvement (OERI). ERIC Document Reproduction Service, Accession No. ED197442. 
systems to equitably finance school districts ${ }^{270}$

\section{Summary}

As society has progressed from agricultural to industrial, the time interval during the transition allowed society to adjust to change gradually. Now, transformation is taking place at a more rapid pace as society moves into the information age and, ultimately, to the age of automation. American society must have the ability to accommodate such rapid change. Not only are things changing, but the number of jobs is declining, and the amount of education and/or retraining required to remain competitive in the job market is increasing. Those who cannot handle the rapidity of change and the need for continuing education will be less able to compete in the years ahead.

As technology moves the United States farther and farther away from a manufacturingbased economy, the American workforce will need to be retrained for jobs that require knowledge-based technologies. What will matter in the 21 st century will be the products of the work of the human mind: scientific and technological research, the educational level of the workforce, sophisticated software, smarter management, advanced communications and electronic finance.

Jobs will become more scarce, and competition for them will increase. This increased tension will lead to additional social tension causing unrest. Crime rates will rise as jobs tighten and money becomes scarcer. It can be anticipated that these tensions will carry over to the

\footnotetext{
${ }^{270}$ Thom, Douglas J. 1990. "Financing Elementary and Secondary Education in Ontario: Toward the Future." Washington: United States Department of Education, Office of Educational Research and Improvement (OERI). ERIC Document Reproduction Service, No. ED324759.
} 
classrooms.

Other dynamics of American society with which schools must contend include the rise in single parent families, child care, dysfunctional families, divorce, residential mobility, the influence of television, and peer pressure. Each of these is a contributing factor in reducing the social relationships that foster children's growth and development.

From outside the United States, there will be a heavier dependence on America's food supplies. Society will require qualified individuals to pursue careers in new or advanced sciences such as microelectronics, biotechnology and medicine. Schools must prepare students to insure that they meet the entry level qualifications for advanced training in these new fields.

America will experience lower birth rates. While birth rates remain stable among the lower class, rates among the middle and upper classes, who support education, will drop. With fewer children enrolled, school districts will have fewer dollars with which to operate. Fewer children require fewer teachers, and with fewer teachers it might be expected that teachers will have less political influence. Another key concern is that when there are fewer children, there will be fewer parents who will actively support public education. Companies that deal in education markets will also become weaker.

In addition to the lowering of the birth rate, the aging of the population will impact the amount of money school systems will have to operate. The elderly, who no longer have students enrolled and do not participate actively in life of the schools, will be less willing to pay for public education. The aging of the population will also cause a shortage of teachers as "baby-boomers" begin to retire from our nation's schools.

Compounding the problem, more of the middle class are and will be moving to private 
schools leaving a larger percentage of lower class students in public schools. With rising incomes and the availability of discretionary dollars, parents will want their children educated in schools with higher academic standards and lower incidences of discipline problems. With fewer students predicted to enroll in the future, colleges increasingly want to offer courses in high schools. This trend can already be seen in West Virginia as colleges and universities now encourage qualifying students in the eleventh grade to take advanced placement courses. Business and industry also want to shorten the span of formal schooling to better insure that they have the needed work force.

The rise of feminism and the movement toward a more heterogeneous society are factors that will influence public education in America. Multicultural and bilingual education will remain important components supporting heterogeneity. There has been a rise in career-oriented women who opt to work rather then suffer the economic loss of having and raising children. Society is becoming more heterogeneous in income, religion, language, ethnicity, value orientation and family type. The more heterogeneous people are, the more difficult it is for them to agree on educational issues. The more difficult it is to agree on educational issues, the stronger the pressure is to move away from a system of majoritarian control of education.

The constant dilemma educators face over juvenile crime and school authority will increase in frequency. Teenage crime is on the rise. Schools must spend already scarce resources on safety and security. Supreme Court decisions affecting expulsion, suspensions, search of lockers, dress regulations and publications have reduced authority over pupils just when the need for it has greatly increased. Educators can expect to be continually involved in the rise in litigation. 
Vouchers, if and when instituted, will be the catalyst that will drive families away from public schools in favor of private schools. Vouchers will only heighten the competition between the public and private schools for students. Setting higher expectations for student learning and performance, optimizing the use of technology to assist classroom instruction, forming more meaningful and working alliances with business and industry, and insuring that our teachers are well trained and flexible enough to adapt to the changes demanded in teaching paradigms will be necessary to keep pace with private schools. Aside from the tuition credit afforded by vouchers, the attractiveness of private schools will be in higher standardized test scores, fewer discipline problems, smaller class sizes, and the fact that they do not have to accept everyone who applies for admission and subsequent enrollment. The emergence of private schools will mean that public schools will be running systems that must remain competitive while teaching students of lesser ability. Unless the public schools are able to overcome the formidable presence of what the private schools of the future are expected to offer, American public education will be reduced to an educational system of lackluster performance which only those who cannot afford better will attend.

The rapid transformation of society has been accelerated by advancements in technology. Rapid changes in the amount that must be learned and how it must be learned have caused corresponding changes in paradigms of teaching and learning. In efforts to adequately prepare students for the world and workplace of the 21 st century, educators have little alternative but to alter their teaching methods and incorporate the latest in technology into the schools.

The expansion of technology will necessitate a massive staff development effort to build teacher competencies in the use of computers and computerized instruction. It appears that the 
biggest impediment to the infusion of technology, aside from money, is the general inability of teachers to use it. In many cases, students are more proficient in the use of technology than their teachers, and at the very least are more comfortable with it.

The social problems facing America have found their way into the schools to the point that the public schools in the United States have become the nation's social service safety net. Schools are expected to reduce crime and drug abuse, provide breakfast and lunch, day care, special services for the disadvantaged, after-school programs, as well as deal with the aftermath of divorce, the influence of TV, child abuse, and parental neglect. Politicians are quick to point out the shortcomings of the public schools, and then expect them to find solutions for national problems.

Public schools will be expected to continue to maintain the balance between providing a quality education and dealing with the problems of the society. Schools are the only social institution in America with the capacity to do this.

Youth in 1998 continue to be deeply bonded to and affirming of the two major social institutions charged with promoting positive human development: family and school. In contrast to popular cultural mythology about these two social institutions, the vast majority of high school students report that their families are sources of support, nurture, and discipline. And most view schools affirmatively, with two-thirds rating their schools' overall performance as A or B. ${ }^{271}$

Out of necessity, educators will have to become more involved with other social service agencies to meet student needs, and with businesses to help curtail deteriorating budgets and provide much needed teacher resources, and become more accommodating to the public for their

\footnotetext{
${ }^{271}$ Horatio Alger Association of Distinguished Americans, 1998. State of Our Nation's Youth, 1998-1999, (http://www.horatioalger.com/pubmat/foreward.htm), p. 1of 3.
} 
continued support of public education.

While public schools will continue to be charged with addressing national problems at the local level, they will do so under the direction of the state and federal governments. As government becomes more and more involved in educational issues, local autonomy will continue to erode. Rather than a top down authoritarian system to address both national problems and educational issues, a reliance on planning and cooperation among schools, business and government will be needed to make educational systems work.

Schools will rely increasingly on businesses for support of school programs, most often associated with student attendance, discipline, academic achievement, and the like. Schools also have found businesses to be valuable resources in the acquisition of specialized learning equipment that would otherwise be unavailable. Public education will continue to be at the mercy of politicians to whom they must look for support for favorable legislation and, ultimately, funding.

The school reform movement has affected virtually every area of public education. The emphasis on paradigm shifts to design and implement new teaching strategies, the raising of expectations and standards, collaborative learning, more efficient use of time, creating more conducive learning environments, decentralization and site-based management have changed the responsibilities and roles of teachers and administrators.

Overall, the number of issues and problems with which public education must deal is continually rising. Educators must anticipate what those problems might be in the year 2020. The actual future will be determined by how educators are able to respond to social, economic, environmental, and political problems. The ills of society cannot be separated from the schools 
since students are products of society. If educators are to make inroads to solving the nation's social problems they must be made through the students in their educational program.

The continued success of public education in America will require high quality, effective educational leaders who have a sound vision for the future. These educational leaders will need to be aggressive in their actions to keep their schools focused on their direction. Their actions must be based on information that will help them implement their vision. This study will provide, through the use of the Delphi technique of forecasting, information on the events that might be anticipated that will affect public education in West Virginia, and perhaps the rest of the nation.

Chapter 3 of this study will discuss the methodology used to assess the future of public education in West Virginia. Chapter 4 will present the data derived from the study and Chapter 5 will provide a scenario for the future of public education in West Virginia, a summary, conclusion, and recommendations for further study. 


\section{CHAPTER 3}

\section{Methodology}

Chapter 3 details the design and procedures used in this Delphi study and describes the instruments and techniques used in gathering data.

\section{Sample}

The subjects in this study consisted of forty-seven individuals who constituted the expert panel. These individuals are representative of the major public education agencies, institutions and constituencies found in West Virginia and were selected for participation on the basis of their skill and knowledge, and their ability to affect and/or influence public education policy in West Virginia.

In all, fifty-one people were identified as potential panel members. Of the fifty-one, fortyseven agreed to serve on the panel. Two declined to participate, and the investigator was unable to contact the other two.

\section{Instruments}

Survey instruments were developed to obtain information from each individual on the panel. Three separate instruments were constructed, one for each round of the Delphi. Each instrument was accompanied by a set of instructions on its completion. 


\section{Delphi Round 1}

In the first round, members of the panel received a survey on which they were asked to identify events that would affect public education in West Virginia between the present and the year 2020 that they felt had at least a fifty percent probability of occurring. This activity created a pool of probable events which the investigator synthesized for use in Rounds 2 and 3. (See Appendix B for Round 1 format.)

\section{Delphi Round 2}

In the second round, a survey was mailed containing a synthesized list of all first round responses (events) from all panel members. Respondents were asked to give their opinion of when each event might occur, and to rate the degree of impact and level of desirability of each event on a seven-point Likert scale. Time frames were developed to represent short (1999-2000), intermediate (2001-2010), and long-range (2011-2020) forecasts. The rating scales used for impact and desirability contained seven response categories ranging from "Low" to "High," 1 to 7, respectively. (See Appendix B for sample of Round 2 format.)

\section{Delphi Round 3}

In the third round, a separate survey was generated for each individual respondent listing those events on which there was a difference between the median group response and the individual expert's response regarding the time frame in which an event might occur. The purpose of Round 3 was to allow each respondent to review the median group response of each event with his/her Round 2 response. Panel members were given the opportunity to change their 
time frame estimates or keep them the same as they appeared in Round 2. Respondents were asked to provide a reason for the time frames they selected if they differed from the median group response. (See Appendix B for sample of Round 3 format.)

\section{Design}

Subjects were surveyed three times using a modified Delphi technique. After the initial survey documents were returned, panel members were provided a list of all events obtained in Round 1 and were asked to identify when the events might occur, and the impact and desirability of each event. Consensus was established in Round 3 where subjects were asked to consider their responses in relation to those of the other panel members. Based on consensus of the panel, a scenario was developed listing events within each time frame.

\section{Procedure}

Each potential member of the expert panel was personally contacted by mail on July 31 , 1998, and invited to participate in the study. This introductory letter of invitation contained a brief explanation of the research problem, a description of the Delphi process, and a proposed timeline for completing the research. One week after the potential panel members received their invitations, each was contacted by telephone so that the researcher could answer any questions they might have and to confirm their participation. During the telephone conversation, the investigator discussed the importance of completing and returning the surveys in a timely manner, and the need for each member to participate in all three rounds of the Delphi. Members of the panel were sent follow-up letters on August 14, 1998, confirming their commitment and thanking them for their willingness to participate in the study. Several panel members were invited to 
participate after the original mailing.

On September 11, 1998, one week prior to the beginning of the study, panel members were sent letters alerting them to the arrival date of the Round 1 survey. This letter again emphasized the importance of completion and return of the surveys by the date specified. The letters also asked the panel members to give consideration to what events might impact public education in West Virginia between the present and the year 2020.

The Round 1 questionnaire was mailed to all forty-seven panel members asking them to respond to the following question: "As I view the future of public education in West Virginia between now and the year 2020, the following events might or should take place.” Responses from the first round were reviewed, reworded to form concise statements of events, organized and grouped according to categories (Students, Personnel, Curriculum, Governance, Facilities, Finance, School-Community Relations, Technology, and Miscellaneous) and then used in the design of the second round survey instrument. In all, one hundred thirty-four events were identified.

The second round survey was mailed to each panel member and contained a complete list of all responses (events) from the first round. Each member was then asked to respond to each item by indicating the approximate time period that each event might occur, and the potential impact and desirability each item might have on public education. Upon receipt of the Round 2 responses, the investigator calculated the median time frame response and the mean impact and desirability rating for each event.

When calculating the median group response, eight events were identified as possibly occurring in two time frames. To resolve the issue, the investigator determined that a modal 
response would be used for each of these events in Round 3.

Once the median group response was calculated for each item, the Round 3 questionnaire was constructed. This questionnaire indicated the panel members' individual Round 2 responses adjacent to the median group responses. Respondents were asked to compare and assess their second round response with the median time predictions of the panel, and then asked to either modify their responses or leave them the same as originally submitted. If panel members decided not to modify their responses, they were asked to offer a reason why they felt the event would happen in the time frame they had selected. These reasons represented and were listed as a minority opinions for each event.

On September 18, 1998, the Round 1 response sheet was mailed to the forty-seven panel members with instructions and directions to complete and return the survey by September 26 . By September 29, only twenty-seven of the forty-seven participants had returned the Round 1 response sheet. On that date, follow-up telephone calls were made to each panel member who had not responded in Round 1. The final total return for Round 1 was forty-two of the fortyseven members, or 89.4 percent. Two of the surveys were considered unusable since they arrived after the distribution of the Round 2 survey instrument. The forty usable Round 1 surveys constituted 85.1 percent of the panel.

On October 7, 1998, the Round 2 response sheet was mailed to the forty-seven panel members. Completion and return of the questionnaire was requested by October 16. Telephone follow-ups to fourteen participants began on October 20. The total return for Round 2 was fortythree of forty-seven, or 91.5 percent.

On October 26, the Round 3 response sheet was mailed to the forty-three respondents 
from Round 2. Repeated telephone follow-ups were made to seven panelists through November 10. The final total return for Round 3 was forty-two of forty-three, or 97.7 percent.

Thirty-nine of the forty-seven panel members, or 83.0 percent, participated in all three rounds of the Delphi. Only one panel member, or 2.1 percent, did not participate in any of the rounds. Four panel members, or 8.5 percent, only participated in one round. Three panel members, or 6.4 percent, only participated in two rounds.

The total time involved in completing the research component of the Delphi was seven weeks. Return time for the questionnaires required approximately five weeks; the other two weeks were required for calculation and constructions of the questionnaires.

\section{Data Analysis}

Responses from the third round were analyzed to identify those items that had a minimum of 80 percent agreement on the projected time frame by all experts surveyed. Events with 80 percent or more consensus were listed as priority events. Events with between 60 to 79 percent consensus constituted secondary events.

Data were organized by area within each projected time frame, and impact and desirability ratings were listed for each event. Separate listings also were made ranking all events according to their levels of impact and desirability. This enabled the determination of high impact/high desirability events which might be actively pursued, and low desirability events which might be avoided.

A scenario was developed for each time frame. Copies of the scenario were forwarded to all panel members at the completion of the study and made generally available upon request. 


\section{CHAPTER 4}

\section{Presentation of the Data}

Chapter 4 will present the data obtained from all three rounds of the Delphi investigation on the future of public education in West Virginia. Each event is presented by the time frame in which, based on group consensus, it will occur. A frequency distribution of the Round 2 and Round 3 responses supplemented by mean impact and desirability ratings are listed for each event. An overview of the reasons offered by participants for their lack of consensus on each event is also presented.

A total of one hundred thirty-four events resulted from the Round 1 response sheet. The distribution of events by time frame based on Round 3 results was as follows:

\begin{tabular}{|c|c|c|c|c|c|}
\hline $\begin{array}{c}\text { Time } \\
\text { Frames }\end{array}$ & $\begin{array}{c}1999- \\
2000\end{array}$ & $\begin{array}{c}2001- \\
2010\end{array}$ & $\begin{array}{c}2011- \\
2020\end{array}$ & $\begin{array}{c}\text { After } \\
2020\end{array}$ & Never \\
\hline \# Events & 0 & 80 & 38 & 5 & 11 \\
\hline
\end{tabular}

\section{1-2010 Time Frame}

Eighty events were forecast to occur between 2001 and 2010. The events are presented in the order in which they appeared on the Round 2 and 3 survey instruments. The number assigned to each event has no special significance, except to denote its numerical placement on those 
survey instruments.

Event 3 projected that "Training for school board members will become more effective." Information related to this event was as follows:

Time Frame Frequency Distribution

\begin{tabular}{|l|c|c|c|c|c|c|c|}
\hline & $\mathrm{N}$ & $\begin{array}{c}1999- \\
2000\end{array}$ & $\begin{array}{c}2001- \\
2010\end{array}$ & $\begin{array}{c}2011- \\
2020\end{array}$ & $\begin{array}{c}\text { After } \\
2020\end{array}$ & Never & NR \\
\hline Round 2 & 43 & 9 & 31 & 0 & 0 & 3 & 0 \\
\hline Round 3 & 42 & 5 & 34 & 1 & 0 & 2 & 0 \\
\hline
\end{tabular}

\section{$\underline{\text { Impact Distribution }}$}

Very Low
\begin{tabular}{|c|c|c|c|c|c|c|}
\hline 1 & 2 & 3 & 4 & 5 & 6 & 7 \\
\hline 1 & 0 & 2 & 8 & 19 & 7 & 6 \\
\hline
\end{tabular}

Mean Impact Rating $=5.07$

Desirability Distribution

Very Low
\begin{tabular}{|c|c|c|c|c|c|c|}
\hline 1 & 2 & 3 & 4 & 5 & 6 & 7 \\
\hline 1 & 0 & 0 & 1 & 10 & 10 & 21 \\
\hline
\end{tabular}

Mean Desirability Rating $=6.09$

Those participants responding in the "1999-2000" category indicated that they felt that training for school board members was improving and would continue to do so. One respondent indicated that training for school board members would never improve until there was some 
change in the present requirements.

Event 5 projected that "Services provided by Regional Education Service Agencies (RESAs) will expand." Time, impact, and desirability data were as follows:

Time Frame Frequency Distribution

\begin{tabular}{|l|c|c|c|c|c|c|c|}
\hline & $\mathrm{N}$ & $\begin{array}{c}1999- \\
2000\end{array}$ & $\begin{array}{c}2001- \\
2010\end{array}$ & $\begin{array}{c}2011- \\
2020\end{array}$ & $\begin{array}{c}\text { After } \\
2020\end{array}$ & Never & NR \\
\hline Round 2 & 43 & 9 & 29 & 3 & 1 & 1 & 0 \\
\hline Round 3 & 42 & 6 & 35 & 0 & 0 & 1 & 0 \\
\hline
\end{tabular}

\section{$\underline{\text { Impact Distribution }}$}

Very Low
\begin{tabular}{|c|c|c|c|c|c|c|}
\hline 1 & 2 & 3 & 4 & 5 & 6 & 7 \\
\hline 1 & 3 & 7 & 10 & 15 & 3 & 4 \\
\hline
\end{tabular}

Mean Impact Rating $=4.40$

Desirability Distribution

Very Low
\begin{tabular}{|c|c|c|c|c|c|c|}
\hline 1 & 2 & 3 & 4 & 5 & 6 & 7 \\
\hline 3 & 1 & 6 & 10 & 9 & 4 & 10 \\
\hline
\end{tabular}

Mean Desirability Rating $=4.70$

Respondents indicated that this event has already begun and further expansion of RESA services is likely. The respondent who indicated that this event would never happen offered no reason for his/her time estimate. 
Event 6 projected that "County school systems will be serviced regionally (transportation, nutrition services, curriculum specialists)." Time, impact, and desirability data were as follows:

Time Frame Frequency Distribution

\begin{tabular}{|l|c|c|c|c|c|c|c|}
\hline & $\mathrm{N}$ & $\begin{array}{c}1999- \\
2000\end{array}$ & $\begin{array}{c}2001- \\
2010\end{array}$ & $\begin{array}{c}2011- \\
2020\end{array}$ & $\begin{array}{c}\text { After } \\
2020\end{array}$ & Never & NR \\
\hline Round 2 & 43 & 0 & 27 & 13 & 2 & 1 & 0 \\
\hline Round 3 & 42 & 0 & 37 & 4 & 1 & 0 & 0 \\
\hline
\end{tabular}

\section{$\underline{\text { Impact Distribution }}$}

Very Low
\begin{tabular}{|c|c|c|c|c|c|c|}
\hline 1 & 2 & 3 & 4 & 5 & 6 & 7 \\
\hline 0 & 1 & 2 & 8 & 18 & 8 & 6 \\
\hline
\end{tabular}

Mean Impact Rating $=5.12$

\section{Desirability Distribution}

Very Low
\begin{tabular}{|c|c|c|c|c|c|c|}
\hline 1 & 2 & 3 & 4 & 5 & 6 & 7 \\
\hline 3 & 2 & 4 & 9 & 12 & 5 & 8 \\
\hline
\end{tabular}

Mean Desirability Rating $=4.67$

All minority respondents indicated that this event would take place later than the median group response. Resistance from the service personnel association and the fear that regional service expansion may ultimately bring about regional school districts were reasons cited for the delay of this event. 
Event 9 projected that "Special interest groups will increase, becoming more active and more vocal." Time, impact, and desirability data were as follows:

\section{Time Frame Frequency Distribution}

\begin{tabular}{|l|c|c|c|c|c|c|c|}
\hline & N & $\begin{array}{c}1999- \\
2000\end{array}$ & $\begin{array}{c}2001- \\
2010\end{array}$ & $\begin{array}{c}2011- \\
2020\end{array}$ & $\begin{array}{c}\text { After } \\
2020\end{array}$ & Never & NR \\
\hline Round 2 & 43 & 11 & 25 & 5 & 0 & 2 & 0 \\
\hline Round 3 & 42 & 8 & 32 & 1 & 0 & 1 & 0 \\
\hline
\end{tabular}

\section{$\underline{\text { Impact Distribution }}$}

Very Low
\begin{tabular}{|c|c|c|c|c|c|c|}
\hline 1 & 2 & 3 & 4 & 5 & 6 & 7 \\
\hline 1 & 1 & 3 & 10 & 9 & 11 & 8 \\
\hline
\end{tabular}

Mean Impact Rating $=5.09$

\section{Desirability Distribution}

Very Low
\begin{tabular}{|c|c|c|c|c|c|c|}
\hline 1 & 2 & 3 & 4 & 5 & 6 & 7 \\
\hline 12 & 13 & 6 & 8 & 1 & 1 & 2 \\
\hline
\end{tabular}

Mean Desirability Rating $=2.63$

Panelists indicating earlier responses pointed out that special interest groups have been increasing each year and would continue to do so, particularly over issues such as School-ToWork, block scheduling, and school violence. One panel member indicated that this event would never happen because special interest groups "will collapse into fewer coalitions to have clout that 
'splinter' groups no longer have."

Event 11 projected that "State government will play a more prominent role in education." Time, impact, and desirability data were as follows:

Time Frame Frequency Distribution

\begin{tabular}{|l|c|c|c|c|c|c|c|}
\hline & $\mathrm{N}$ & $\begin{array}{c}1999- \\
2000\end{array}$ & $\begin{array}{c}2001- \\
2010\end{array}$ & $\begin{array}{c}2011- \\
2020\end{array}$ & $\begin{array}{c}\text { After } \\
2020\end{array}$ & Never & NR \\
\hline Round 2 & 43 & 17 & 16 & 6 & 2 & 2 & 0 \\
\hline Round 3 & 42 & 8 & 30 & 2 & 1 & 1 & 0 \\
\hline
\end{tabular}

\section{$\underline{\text { Impact Distribution }}$}

Very Low
\begin{tabular}{|c|c|c|c|c|c|c|}
\hline 1 & 2 & 3 & 4 & 5 & 6 & 7 \\
\hline 1 & 0 & 1 & 7 & 8 & 15 & 11 \\
\hline
\end{tabular}

Mean Impact Rating $=5.56$

Desirability Distribution

Very Low
\begin{tabular}{|c|c|c|c|c|c|c|}
\hline 1 & 2 & 3 & 4 & 5 & 6 & 7 \\
\hline 9 & 10 & 9 & 9 & 1 & 4 & 1 \\
\hline
\end{tabular}

Mean Desirability Rating $=2.98$

Earlier responses indicated that this event is already occurring as evidenced by the increased accountability of local districts and schools, the emergence of the new Office of Education Performance Audits, and continuing enactments by the legislature that impact 
education. Those predicting a later time of occurrence indicated that this event contradicts the current trend of devolution of control from the state to the local level, and that a funding change might cause this to happen.

Event 13 projected that "There will be closure on the role of the courts in the interpretation of "thorough and efficient education." Time, impact, and desirability data were as follows:

Time Frame Frequency Distribution

\begin{tabular}{|l|c|c|c|c|c|c|c|}
\hline & $\mathrm{N}$ & $\begin{array}{c}1999- \\
2000\end{array}$ & $\begin{array}{c}2001- \\
2010\end{array}$ & $\begin{array}{c}2011- \\
2020\end{array}$ & $\begin{array}{c}\text { After } \\
2020\end{array}$ & Never & NR \\
\hline Round 2 & 43 & 6 & 21 & 4 & 1 & 11 & 0 \\
\hline Round 3 & 42 & 1 & 30 & 2 & 1 & 8 & 0 \\
\hline
\end{tabular}

Impact Distribution

Very Low
\begin{tabular}{|c|c|c|c|c|c|c|}
\hline 1 & 2 & 3 & 4 & 5 & 6 & 7 \\
\hline 0 & 2 & 1 & 8 & 8 & 8 & 16 \\
\hline
\end{tabular}

Mean Impact Rating $=5.56$

Desirability Distribution

Very Low
\begin{tabular}{|c|c|c|c|c|c|c|}
\hline 1 & 2 & 3 & 4 & 5 & 6 & 7 \\
\hline 3 & 2 & 0 & 7 & 4 & 10 & 17 \\
\hline
\end{tabular}

Mean Desirability Rating $=5.44$ 
All respondents who commented indicated that this event would occur later than the median group response. Comments included that "this item is doomed to eternal discussion because of the vagueness of the terms "thorough and efficient," and that "Closure is only another lawsuit from opening up again."

Event 14 projected that "Distance learning opportunities will increase as staff cuts occur and world-class instruction in specialized areas will be provided." Time, impact, and desirability data were as follows:

\section{Time Frame Frequency Distribution}

\begin{tabular}{|l|c|c|c|c|c|c|c|}
\hline & $\mathrm{N}$ & $\begin{array}{c}1999- \\
2000\end{array}$ & $\begin{array}{c}2001- \\
2010\end{array}$ & $\begin{array}{c}2011- \\
2020\end{array}$ & $\begin{array}{c}\text { After } \\
2020\end{array}$ & Never & NR \\
\hline Round 2 & 43 & 3 & 27 & 9 & 2 & 2 & 0 \\
\hline Round 3 & 42 & 2 & 35 & 4 & 1 & 0 & 0 \\
\hline
\end{tabular}

\section{Impact Distribution}

Very Low
\begin{tabular}{|c|c|c|c|c|c|c|}
\hline 1 & 2 & 3 & 4 & 5 & 6 & 7 \\
\hline 1 & 1 & 0 & 6 & 13 & 17 & 5 \\
\hline
\end{tabular}

Mean Impact Rating $=5.33$

\section{Desirability Distribution}

Very Low
\begin{tabular}{|c|c|c|c|c|c|c|}
\hline 1 & 2 & 3 & 4 & 5 & 6 & 7 \\
\hline 2 & 4 & 5 & 7 & 10 & 5 & 10 \\
\hline
\end{tabular}

Mean Desirability Rating $=4.72$ 
Respondents who disagreed with the median group response felt that, although distance learning was already increasing, it should not be linked to reductions in staff. One respondent stated that "There is a natural limit to the usefulness of technology to supplant staff."

Event 15 projected that "All schools will be networked via computers." Time, impact, and desirability data were as follows:

\section{Time Frame Frequency Distribution}

\begin{tabular}{|l|c|c|c|c|c|c|c|}
\hline & $\mathrm{N}$ & $\begin{array}{c}1999- \\
2000\end{array}$ & $\begin{array}{c}2001- \\
2010\end{array}$ & $\begin{array}{c}2011- \\
2020\end{array}$ & $\begin{array}{c}\text { After } \\
2020\end{array}$ & Never & NR \\
\hline Round 2 & 43 & 9 & 26 & 6 & 2 & 0 & 0 \\
\hline Round 3 & 42 & 9 & 31 & 2 & 0 & 0 & 0 \\
\hline
\end{tabular}

\section{$\underline{\text { Impact Distribution }}$}

Very Low
\begin{tabular}{|c|c|c|c|c|c|c|}
\hline 1 & 2 & 3 & 4 & 5 & 6 & 7 \\
\hline 0 & 0 & 1 & 7 & 14 & 10 & 10 \\
\hline
\end{tabular}

No Response $=1$

Mean Impact Rating $=5.50$

\section{Desirability Distribution}

Very Low
\begin{tabular}{|c|c|c|c|c|c|c|}
\hline 1 & 2 & 3 & 4 & 5 & 6 & 7 \\
\hline 0 & 0 & 0 & 3 & 11 & 9 & 19 \\
\hline
\end{tabular}

No Response $=1$

Mean Desirability Rating $=6.05$ 
Several respondents felt that this event was currently happening, and in many cases it is through the West Virginia Education Information System (WVEIS) and Internet accessibility in the schools. One respondent cited the huge cost of equipment that the state or counties could not afford until a later date which would delay the event.

Event 16 projected that "There will be computer connections between home and school." Time, impact, and desirability data were as follows:

Time Frame Frequency Distribution

\begin{tabular}{|l|c|c|c|c|c|c|c|}
\hline & $\mathrm{N}$ & $\begin{array}{c}1999- \\
2000\end{array}$ & $\begin{array}{c}2001- \\
2010\end{array}$ & $\begin{array}{c}2011- \\
2020\end{array}$ & $\begin{array}{c}\text { After } \\
2020\end{array}$ & Never & NR \\
\hline Round 2 & 43 & 1 & 26 & 14 & 2 & 0 & 0 \\
\hline Round 3 & 42 & 1 & 33 & 8 & 0 & 0 & 0 \\
\hline
\end{tabular}

Impact Distribution

Very Low
\begin{tabular}{|c|c|c|c|c|c|c|}
\hline 1 & 2 & 3 & 4 & 5 & 6 & 7 \\
\hline 0 & 0 & 3 & 7 & 10 & 10 & 13 \\
\hline
\end{tabular}

Mean Impact Rating $=5.53$

$\underline{\text { Desirability Distribution }}$

Very Low
\begin{tabular}{|c|c|c|c|c|c|c|}
\hline 1 & 2 & 3 & 4 & 5 & 6 & 7 \\
\hline 0 & 0 & 0 & 2 & 16 & 10 & 15 \\
\hline
\end{tabular}

Mean Desirability Rating $=5.88$ 
The earlier response indicated that this event was already beginning and would continue to occur over several time frames. Later responses cited cost and outdated wiring, equipment and connections that would have to be replaced at both home and school which would delay the event.

Event 17 projected that "Federal legislation will be passed allowing for continual E-rate funding." Time, impact, and desirability data were as follows:

Time Frame Frequency Distribution

\begin{tabular}{|l|c|c|c|c|c|c|c|}
\hline & $\mathrm{N}$ & $\begin{array}{c}1999- \\
2000\end{array}$ & $\begin{array}{c}2001- \\
2010\end{array}$ & $\begin{array}{c}2011- \\
2020\end{array}$ & $\begin{array}{c}\text { After } \\
2020\end{array}$ & Never & NR \\
\hline Round 2 & 43 & 10 & 20 & 5 & 0 & 4 & 4 \\
\hline Round 3 & 42 & 6 & 29 & 2 & 0 & 2 & 3 \\
\hline
\end{tabular}

\section{Impact Distribution}

Very Low
\begin{tabular}{|c|c|c|c|c|c|c|}
\hline 1 & 2 & 3 & 4 & 5 & 6 & 7 \\
\hline 0 & 3 & 2 & 8 & 9 & 11 & 5 \\
\hline
\end{tabular}

No Response $=5$

Mean Impact Rating $=5.00$

\section{Desirability Distribution}

Very Low
\begin{tabular}{|c|c|c|c|c|c|c|}
\hline 1 & 2 & 3 & 4 & 5 & 6 & 7 \\
\hline 0 & 0 & 2 & 5 & 9 & 10 & 12 \\
\hline
\end{tabular}

No Response $=5$

Mean Desirability Rating $=5.66$ 
Earlier responses indicated that E-rates were a high priority item that would be approved by Congress. Later responses cited pressure from opposition which would delay or eliminate the E-rates.

Event 19 projected that "Computers will change the education structure to allow for flexible scheduling for students." Time, impact, and desirability data were as follows:

\section{Time Frame Frequency Distribution}

\begin{tabular}{|l|c|c|c|c|c|c|c|}
\hline & $\mathrm{N}$ & $\begin{array}{c}1999- \\
2000\end{array}$ & $\begin{array}{c}2001- \\
2010\end{array}$ & $\begin{array}{c}2011- \\
2020\end{array}$ & $\begin{array}{c}\text { After } \\
2020\end{array}$ & Never & NR \\
\hline Round 2 & 43 & 0 & 24 & 11 & 5 & 3 & 0 \\
\hline Round 3 & 42 & 0 & 36 & 2 & 1 & 3 & 0 \\
\hline
\end{tabular}

\section{$\underline{\text { Impact Distribution }}$}

Very Low
\begin{tabular}{|c|c|c|c|c|c|c|}
\hline 1 & 2 & 3 & 4 & 5 & 6 & 7 \\
\hline 0 & 0 & 4 & 8 & 6 & 10 & 15 \\
\hline
\end{tabular}

$$
\text { Mean Impact Rating }=5.56
$$

\section{Desirability Distribution}

Very Low
\begin{tabular}{|c|c|c|c|c|c|c|}
\hline 1 & 2 & 3 & 4 & 5 & 6 & 7 \\
\hline 1 & 1 & 4 & 7 & 6 & 11 & 13 \\
\hline
\end{tabular}

Mean Desirability Rating $=5.35$

All minority opinions indicated that this event would occur later that the group median 
response. Opinions expressed were that scheduling problems would be fixed if computers were the solution, and that in the future, "technology in the classroom will continue to increase, it will be some time before we see revolutionary rather than evolutionary changes."

Event 21 projected that "Two-way cameras will allow for interaction between teachers and students." Time, impact, and desirability data were as follows:

\section{Time Frame Frequency Distribution}

\begin{tabular}{|l|c|c|c|c|c|c|c|}
\hline & $\mathrm{N}$ & $\begin{array}{c}1999- \\
2000\end{array}$ & $\begin{array}{c}2001- \\
2010\end{array}$ & $\begin{array}{c}2011- \\
2020\end{array}$ & $\begin{array}{c}\text { After } \\
2020\end{array}$ & Never & NR \\
\hline Round 2 & 43 & 5 & 17 & 10 & 6 & 3 & 2 \\
\hline Round 3 & 42 & 4 & 27 & 6 & 3 & 1 & 1 \\
\hline
\end{tabular}

\section{$\underline{\text { Impact Distribution }}$}

Very Low
\begin{tabular}{|c|c|c|c|c|c|c|}
\hline 1 & 2 & 3 & 4 & 5 & 6 & 7 \\
\hline 1 & 3 & 3 & 13 & 9 & 5 & 7 \\
\hline
\end{tabular}

No Response $=2$

Mean Impact Rating $=4.68$

\section{Desirability Distribution}

Very Low
\begin{tabular}{|c|c|c|c|c|c|c|}
\hline 1 & 2 & 3 & 4 & 5 & 6 & 7 \\
\hline 5 & 2 & 4 & 12 & 8 & 5 & 5 \\
\hline
\end{tabular}

No Response $=2$

Mean Desirability Rating $=4.24$ 
Respondents indicated that two-way cameras are already being used and will continue to proliferate. Those who chose a later time frame mentioned cost as the primary factor slowing this event's occurrence.

Event 23 projected that "There will be increased emphasis on the use of technology in teacher training programs." Time, impact, and desirability data were as follows:

\section{Time Frame Frequency Distribution}

\begin{tabular}{|l|c|c|c|c|c|c|c|}
\hline & $\mathrm{N}$ & $\begin{array}{c}1999- \\
2000\end{array}$ & $\begin{array}{c}2001- \\
2010\end{array}$ & $\begin{array}{c}2011- \\
2020\end{array}$ & $\begin{array}{c}\text { After } \\
2020\end{array}$ & Never & NR \\
\hline Round 2 & 43 & 15 & 24 & 3 & 0 & 0 & 1 \\
\hline Round 3 & 42 & 9 & 31 & 2 & 0 & 0 & 0 \\
\hline
\end{tabular}

\section{$\underline{\text { Impact Distribution }}$}

Very Low
\begin{tabular}{|c|c|c|c|c|c|c|}
\hline 1 & 2 & 3 & 4 & 5 & 6 & 7 \\
\hline 0 & 0 & 0 & 5 & 12 & 13 & 12 \\
\hline
\end{tabular}

No Response $=1$

Mean Impact Rating $=5.76$

\section{Desirability Distribution}

Very Low
\begin{tabular}{|c|c|c|c|c|c|c|}
\hline 1 & 2 & 3 & 4 & 5 & 6 & 7 \\
\hline 0 & 0 & 0 & 3 & 4 & 11 & 24 \\
\hline
\end{tabular}

No Response $=1$

Mean Desirability Rating $=6.33$ 
Respondents who commented all felt that this event had already begun and cited West Virginia University and Bethany College as examples. One panelist stated that "Increased use of technology in pre-service teacher training as well as appropriate in-service programs are already required and available as per the revised SDE SB-5100 standards, the new High Tech Consortium Instructional Technology Project ( $\$ 3$ million over 4 years), and the new State Professional Development Standards." Others mentioned that this emphasis is a part of the National Council for Accreditation of Teacher Education (NCATE) standards.

Event 24 projected that "Accountability standards for students will be enacted." Time, impact, and desirability data were as follows:

Time Frame Frequency Distribution

\begin{tabular}{|l|c|c|c|c|c|c|c|}
\hline & $\mathrm{N}$ & $\begin{array}{c}1999- \\
2000\end{array}$ & $\begin{array}{c}2001- \\
2010\end{array}$ & $\begin{array}{c}2011- \\
2020\end{array}$ & $\begin{array}{c}\text { After } \\
2020\end{array}$ & Never & NR \\
\hline Round 2 & 43 & 3 & 31 & 7 & 0 & 0 & 2 \\
\hline Round 3 & 42 & 3 & 37 & 1 & 0 & 0 & 1 \\
\hline
\end{tabular}

\section{$\underline{\text { Impact Distribution }}$}

Very Low
\begin{tabular}{|c|c|c|c|c|c|c|}
\hline 1 & 2 & 3 & 4 & 5 & 6 & 7 \\
\hline 0 & 0 & 0 & 2 & 12 & 12 & 15 \\
\hline
\end{tabular}

No Response $=2$

Mean Impact Rating $=5.98$ 


\section{Desirability Distribution}

Very Low
\begin{tabular}{|c|c|c|c|c|c|c|}
\hline 1 & 2 & 3 & 4 & 5 & 6 & 7 \\
\hline 1 & 0 & 2 & 7 & 8 & 6 & 17 \\
\hline
\end{tabular}

No Response $=2$

Mean Desirability Rating $=5.61$

Early responses indicated that accountability standards are already in place as evidenced by the use of the SAT-9 and accreditation standards, SB300, and the student warranty program. Event 31 projected that "Students will earn credits by taking "official" achievement tests to demonstrate subject mastery on their computers." Time, impact, and desirability data were as follows:

Time Frame Frequency Distribution

\begin{tabular}{|l|c|c|c|c|c|c|c|}
\hline & $\mathrm{N}$ & $\begin{array}{c}1999- \\
2000\end{array}$ & $\begin{array}{c}2001- \\
2010\end{array}$ & $\begin{array}{c}2011- \\
2020\end{array}$ & $\begin{array}{c}\text { After } \\
2020\end{array}$ & Never & NR \\
\hline Round 2 & 43 & 0 & 21 & 18 & 4 & 0 & 0 \\
\hline Round 3 & 42 & 0 & 36 & 5 & 1 & 0 & 0 \\
\hline
\end{tabular}

$\underline{\text { Impact Distribution }}$

Very Low
\begin{tabular}{|c|c|c|c|c|c|c|}
\hline 1 & 2 & 3 & 4 & 5 & 6 & 7 \\
\hline 1 & 0 & 2 & 13 & 8 & 13 & 6 \\
\hline
\end{tabular}

Mean Impact Rating $=5.09$ 


\section{Desirability Distribution}

Very Low
\begin{tabular}{|c|c|c|c|c|c|c|}
\hline 1 & 2 & 3 & 4 & 5 & 6 & 7 \\
\hline 1 & 3 & 8 & 12 & 6 & 8 & 5 \\
\hline
\end{tabular}

Mean Desirability Rating $=4.47$

All minority opinion respondents indicated that this event would be delayed in occurring, but gave no specific reasons for such a delay.

Event 32 projected that "Speech recognition software will replace the need to have keyboarding skills." Time, impact, and desirability data were as follows:

$\underline{\text { Time Frame Frequency Distribution }}$

\begin{tabular}{|l|c|c|c|c|c|c|c|}
\hline & N & $\begin{array}{c}1999- \\
2000\end{array}$ & $\begin{array}{c}2001- \\
2010\end{array}$ & $\begin{array}{c}2011- \\
2020\end{array}$ & $\begin{array}{c}\text { After } \\
2020\end{array}$ & Never & NR \\
\hline Round 2 & 43 & 0 & 21 & 9 & 6 & 6 & 1 \\
\hline Round 3 & 42 & 0 & 30 & 7 & 0 & 4 & 1 \\
\hline
\end{tabular}

\section{Impact Distribution}

Very Low
\begin{tabular}{|c|c|c|c|c|c|c|}
\hline 1 & 2 & 3 & 4 & 5 & 6 & 7 \\
\hline 2 & 1 & 2 & 10 & 11 & 6 & 11 \\
\hline
\end{tabular}

No Response $=1$

Mean Impact Rating $=5.07$ 


\section{Desirability Distribution}

Very Low
\begin{tabular}{|c|c|c|c|c|c|c|}
\hline 1 & 2 & 3 & 4 & 5 & 6 & 7 \\
\hline 2 & 6 & 3 & 9 & 4 & 5 & 13 \\
\hline
\end{tabular}

No Response $=1$

Mean Desirability Rating $=4.76$

Responses from the "2011-2020" and "Never" time frames pointed to the current availability of voice-recognition software, but cautioned that it would take several time frames to develop it into meaningful usage. It was also mentioned that keyboards would continue to have uses.

Event 34 projected that "A state curriculum and standards will be established that will drive what is taught and tested." Time, impact, and desirability data were as follows:

\section{Time Frame Frequency Distribution}

\begin{tabular}{|l|c|c|c|c|c|c|c|}
\hline & $\mathrm{N}$ & $\begin{array}{c}1999- \\
2000\end{array}$ & $\begin{array}{c}2001- \\
2010\end{array}$ & $\begin{array}{c}2011- \\
2020\end{array}$ & $\begin{array}{c}\text { After } \\
2020\end{array}$ & Never & NR \\
\hline Round 2 & 43 & 18 & 21 & 2 & 1 & 0 & 1 \\
\hline Round 3 & 42 & 6 & 34 & 0 & 0 & 0 & 2 \\
\hline
\end{tabular}

\section{Impact Distribution}

Very Low
\begin{tabular}{|c|c|c|c|c|c|c|}
\hline 1 & 2 & 3 & 4 & 5 & 6 & 7 \\
\hline 0 & 0 & 0 & 9 & 8 & 11 & 14 \\
\hline
\end{tabular}

No Response $=1$

Mean Impact Rating $=5.71$ 


\section{Desirability Distribution}

Very Low
\begin{tabular}{|c|c|c|c|c|c|c|}
\hline 1 & 2 & 3 & 4 & 5 & 6 & 7 \\
\hline 4 & 5 & 6 & 6 & 6 & 5 & 10 \\
\hline
\end{tabular}

No Response $=1$

Mean Desirability Rating $=4.43$

All respondents who commented indicated that this event was currently in place through the West Virginia Instructional Goals and Objectives and the SAT-9 test which now provide the statewide "curriculum frameworks and standardized test."

Event 35 projected that "The state assessment program will be revised." Time, impact, and desirability data were as follows:

Time Frame Frequency Distribution

\begin{tabular}{|l|c|c|c|c|c|c|c|}
\hline & $\mathrm{N}$ & $\begin{array}{c}1999- \\
2000\end{array}$ & $\begin{array}{c}2001- \\
2010\end{array}$ & $\begin{array}{c}2011- \\
2020\end{array}$ & $\begin{array}{c}\text { After } \\
2020\end{array}$ & Never & NR \\
\hline Round 2 & 43 & 9 & 32 & 1 & 0 & 0 & 0 \\
\hline Round 3 & 42 & 3 & 39 & 0 & 0 & 0 & 0 \\
\hline
\end{tabular}

\section{Impact Distribution}

Very Low
\begin{tabular}{|c|c|c|c|c|c|c|}
\hline 1 & 2 & 3 & 4 & 5 & 6 & 7 \\
\hline 2 & 2 & 2 & 13 & 11 & 9 & 4 \\
\hline
\end{tabular}

Mean Impact Rating $=4.67$ 


\section{Desirability Distribution}

Very Low
\begin{tabular}{|c|c|c|c|c|c|c|}
\hline 1 & 2 & 3 & 4 & 5 & 6 & 7 \\
\hline 1 & 0 & 4 & 14 & 5 & 7 & 12 \\
\hline
\end{tabular}

Mean Desirability Rating $=5.12$

The three respondents who indicated that this event would occur in the "1999-2000" category stated that revisions of the state assessment program are currently being considered, but that changes probably would not take place until 2001-2010.

Event 36 projected that “More emphasis will be placed on assessment of student performance including test scores, skills, and trades." Time, impact, and desirability data were as follows:

Time Frame Frequency Distribution

\begin{tabular}{|l|c|c|c|c|c|c|c|}
\hline & $\mathrm{N}$ & $\begin{array}{c}1999- \\
2000\end{array}$ & $\begin{array}{c}2001- \\
2010\end{array}$ & $\begin{array}{c}2011- \\
2020\end{array}$ & $\begin{array}{c}\text { After } \\
2020\end{array}$ & Never & NR \\
\hline Round 2 & 43 & 8 & 31 & 2 & 0 & 0 & 0 \\
\hline Round 3 & 42 & 9 & 33 & 0 & 0 & 0 & 0 \\
\hline
\end{tabular}

Impact Distribution

Very Low
\begin{tabular}{|c|c|c|c|c|c|c|}
\hline 1 & 2 & 3 & 4 & 5 & 6 & 7 \\
\hline 1 & 1 & 0 & 10 & 12 & 12 & 7 \\
\hline
\end{tabular}

Mean Impact Rating $=5.21$ 


\section{Desirability Distribution}

Very Low
\begin{tabular}{|c|c|c|c|c|c|c|}
\hline 1 & 2 & 3 & 4 & 5 & 6 & 7 \\
\hline 3 & 3 & 5 & 12 & 6 & 5 & 9 \\
\hline
\end{tabular}

Mean Desirability Rating $=4.53$

All respondents who commented indicated that this event would occur before the median group response. Emphasis on assessment was cited as a national trend in which the stakes get higher annually.

Event 37 projected that "High school graduation requirements will increase." Time, impact, and desirability data were as follows:

Time Frame Frequency Distribution

\begin{tabular}{|l|c|c|c|c|c|c|c|}
\hline & N & $\begin{array}{c}1999- \\
2000\end{array}$ & $\begin{array}{c}2001- \\
2010\end{array}$ & $\begin{array}{c}2011- \\
2020\end{array}$ & $\begin{array}{c}\text { After } \\
2020\end{array}$ & Never & NR \\
\hline Round 2 & 43 & 2 & 39 & 0 & 0 & 2 & 0 \\
\hline Round 3 & 42 & 0 & 41 & 0 & 0 & 1 & 0 \\
\hline
\end{tabular}

\section{Impact Distribution}

Very Low
\begin{tabular}{|c|c|c|c|c|c|c|}
\hline 1 & 2 & 3 & 4 & 5 & 6 & 7 \\
\hline 1 & 1 & 2 & 9 & 12 & 9 & 8 \\
\hline
\end{tabular}

No Response $=1$

Mean Impact Rating $=5.12$ 


\section{Desirability Distribution}

Very Low
\begin{tabular}{|c|c|c|c|c|c|c|}
\hline 1 & 2 & 3 & 4 & 5 & 6 & 7 \\
\hline 3 & 4 & 3 & 6 & 9 & 8 & 10 \\
\hline
\end{tabular}

Mean Desirability Rating $=4.81$

Only one comment was received from the "Never" category which indicated that high school graduation "requirements will change but not be increased."

Event 38 projected that "Students will have more independent study classes in which they will complete projects for credit." Time, impact, and desirability data were as follows:

Time Frame Frequency Distribution

\begin{tabular}{|l|c|c|c|c|c|c|c|}
\hline & N & $\begin{array}{c}1999- \\
2000\end{array}$ & $\begin{array}{c}2001- \\
2010\end{array}$ & $\begin{array}{c}2011- \\
2020\end{array}$ & $\begin{array}{c}\text { After } \\
2020\end{array}$ & Never & NR \\
\hline Round 2 & 43 & 0 & 29 & 11 & 1 & 2 & 0 \\
\hline Round 3 & 42 & 0 & 38 & 1 & 1 & 2 & 0 \\
\hline
\end{tabular}

\section{Impact Distribution}

Very Low
\begin{tabular}{|c|c|c|c|c|c|c|}
\hline 1 & 2 & 3 & 4 & 5 & 6 & 7 \\
\hline 0 & 1 & 3 & 17 & 13 & 2 & 7 \\
\hline
\end{tabular}

Mean Impact Rating $=4.77$ 


\section{Desirability Distribution}

Very Low
\begin{tabular}{|c|c|c|c|c|c|c|}
\hline 1 & 2 & 3 & 4 & 5 & 6 & 7 \\
\hline 1 & 5 & 3 & 10 & 11 & 6 & 7 \\
\hline
\end{tabular}

Mean Desirability Rating $=4.67$

Only two respondents commented on this event which they estimated would never happen. One stated that "Students have always needed direct teaching so that learning will occur. Socialization is a necessity as well!" The other respondent wrote "This can be a valuable education experience if resources are available."

Event 39 projected that "There will be an increased emphasis on School-To-Work from business and industry." Time, impact, and desirability data were as follows:

Time Frame Frequency Distribution

\begin{tabular}{|l|c|c|c|c|c|c|c|}
\hline & N & $\begin{array}{c}1999- \\
2000\end{array}$ & $\begin{array}{c}2001- \\
2010\end{array}$ & $\begin{array}{c}2011- \\
2020\end{array}$ & $\begin{array}{c}\text { After } \\
2020\end{array}$ & Never & NR \\
\hline Round 2 & 43 & 9 & 29 & 1 & 0 & 4 & 0 \\
\hline Round 3 & 42 & 4 & 36 & 0 & 0 & 2 & 0 \\
\hline
\end{tabular}

\section{Impact Distribution}

Very Low
\begin{tabular}{|c|c|c|c|c|c|c|}
\hline 1 & 2 & 3 & 4 & 5 & 6 & 7 \\
\hline 1 & 2 & 4 & 10 & 11 & 9 & 5 \\
\hline
\end{tabular}

No Response $=1$

Mean Impact Rating $=4.79$ 


\section{Desirability Distribution}

Very Low
\begin{tabular}{|c|c|c|c|c|c|c|}
\hline 1 & 2 & 3 & 4 & 5 & 6 & 7 \\
\hline 3 & 3 & 2 & 11 & 8 & 9 & 6 \\
\hline
\end{tabular}

No Response $=1$

Mean Desirability Rating $=4.64$

All respondents who commented indicated that this event was already occurring. One respondent stated that influence of business and industry on School-To-Work "will be sustained but not increased." Another stated that "It's already emphasized significantly and I think the mood of business is that this is as much energy as they will expend until periodic labor shortages demand it."

Event 40 projected that "Businesses will become more involved in student training through mentorships and research 'fellowships."' Time, impact, and desirability data were as follows:

Time Frame Frequency Distribution

\begin{tabular}{|l|c|c|c|c|c|c|c|}
\hline & $\mathrm{N}$ & $\begin{array}{c}1999- \\
2000\end{array}$ & $\begin{array}{c}2001- \\
2010\end{array}$ & $\begin{array}{c}2011- \\
2020\end{array}$ & $\begin{array}{c}\text { After } \\
2020\end{array}$ & Never & NR \\
\hline Round 2 & 43 & 1 & 32 & 5 & 1 & 4 & 0 \\
\hline Round 3 & 43 & 0 & 37 & 0 & 1 & 4 & 0 \\
\hline
\end{tabular}




\section{Impact Distribution}

Very Low
\begin{tabular}{|c|c|c|c|c|c|c|}
\hline 1 & 2 & 3 & 4 & 5 & 6 & 7 \\
\hline 1 & 2 & 3 & 13 & 10 & 8 & 5 \\
\hline
\end{tabular}

No Response $=1$

Mean Impact Rating $=4.74$

Desirability Distribution

Very Low
\begin{tabular}{|c|c|c|c|c|c|c|}
\hline 1 & 2 & 3 & 4 & 5 & 6 & 7 \\
\hline 0 & 2 & 3 & 7 & 12 & 9 & 9 \\
\hline & No Response $=1$ \\
Mean Desirability Rating = 5.19
\end{tabular}

Minority respondents all felt that this event would occur later than the median group response. Comments expressed some skepticism about the over involvement of business in the School-To-Work program, except "on their own initiative." "Businesses are willing to train employees, but they want school to do the work before students leave school."

Event 42 projected that "Education will become more focused on teaching problem solving, access to data bases, and the use of technology." Time, impact, and desirability data were as follows: 
$\underline{\text { Time Frame Frequency Distribution }}$

\begin{tabular}{|l|c|c|c|c|c|c|c|}
\hline & $\mathrm{N}$ & $\begin{array}{c}1999- \\
2000\end{array}$ & $\begin{array}{c}2001- \\
2010\end{array}$ & $\begin{array}{c}2011- \\
2020\end{array}$ & $\begin{array}{c}\text { After } \\
2020\end{array}$ & Never & NR \\
\hline Round 2 & 43 & 5 & 28 & 6 & 4 & 0 & 0 \\
\hline Round 3 & 42 & 1 & 37 & 1 & 3 & 0 & 0 \\
\hline
\end{tabular}

\section{$\underline{\text { Impact Distribution }}$}

Very Low
\begin{tabular}{|c|c|c|c|c|c|c|}
\hline 1 & 2 & 3 & 4 & 5 & 6 & 7 \\
\hline 0 & 0 & 1 & 8 & 12 & 14 & 8 \\
\hline
\end{tabular}

Mean Impact Rating $=5.47$

Desirability Distribution

Very Low
\begin{tabular}{|c|c|c|c|c|c|c|}
\hline 1 & 2 & 3 & 4 & 5 & 6 & 7 \\
\hline 0 & 2 & 2 & 6 & 7 & 12 & 14 \\
\hline
\end{tabular}

Mean Desirability Rating $=5.56$

One respondent from the "After 2020" time frame stated that "The focus should remain on the basic skills of which technology is a part. Problem solving is taught during work-based learning experiences."

Event 44 projected that "Programs will be developed for all 3 and/or 4 year olds." Time, impact, and desirability data were as follows: 
$\underline{\text { Time Frame Frequency Distribution }}$

\begin{tabular}{|l|c|c|c|c|c|c|c|}
\hline & $\mathrm{N}$ & $\begin{array}{c}1999- \\
2000\end{array}$ & $\begin{array}{c}2001- \\
2010\end{array}$ & $\begin{array}{c}2011- \\
2020\end{array}$ & $\begin{array}{c}\text { After } \\
2020\end{array}$ & Never & NR \\
\hline Round 2 & 43 & 0 & 32 & 7 & 2 & 2 & 0 \\
\hline Round 3 & 42 & 0 & 32 & 8 & 1 & 1 & 0 \\
\hline
\end{tabular}

\section{$\underline{\text { Impact Distribution }}$}

Very Low
\begin{tabular}{|c|c|c|c|c|c|c|}
\hline 1 & 2 & 3 & 4 & 5 & 6 & 7 \\
\hline 0 & 0 & 0 & 4 & 11 & 13 & 15 \\
\hline
\end{tabular}

Mean Impact Rating $=5.91$

Desirability Distribution

Very Low
\begin{tabular}{|c|c|c|c|c|c|c|}
\hline 1 & 2 & 3 & 4 & 5 & 6 & 7 \\
\hline 2 & 2 & 3 & 3 & 4 & 10 & 19 \\
\hline
\end{tabular}

Mean Desirability Rating $=5.58$

All respondents who commented indicated that this event would occur later than the median group response. The primary reason cited for the delay in occurrence was cost of implementation. One respondent indicated that this might be made available in "our most needy communities," but not necessarily "for all" students. The "Never" respondent indicated that programs for 3 and 4 year olds would never be a part of the formed education structure, but might exist in the form of head start programs.

Event 45 projected that "State certification will be required for pre-school teachers." 
Time, impact, and desirability data were as follows:

Time Frame Frequency Distribution

\begin{tabular}{|l|c|c|c|c|c|c|c|}
\hline & $\mathrm{N}$ & $\begin{array}{c}1999- \\
2000\end{array}$ & $\begin{array}{c}2001- \\
2010\end{array}$ & $\begin{array}{c}2011- \\
2020\end{array}$ & $\begin{array}{c}\text { After } \\
2020\end{array}$ & Never & NR \\
\hline Round 2 & 43 & 4 & 33 & 4 & 0 & 2 & 0 \\
\hline Round 3 & 42 & 2 & 37 & 2 & 0 & 1 & 0 \\
\hline
\end{tabular}

\section{Impact Distribution}

Very Low
\begin{tabular}{|c|c|c|c|c|c|c|}
\hline 1 & 2 & 3 & 4 & 5 & 6 & 7 \\
\hline 0 & 2 & 2 & 10 & 13 & 9 & 8 \\
\hline
\end{tabular}

Mean Impact Rating $=5.11$

$\underline{\text { Desirability Distribution }}$

Very Low
\begin{tabular}{|c|c|c|c|c|c|c|}
\hline 1 & 2 & 3 & 4 & 5 & 6 & 7 \\
\hline 0 & 1 & 1 & 8 & 7 & 9 & 18 \\
\hline
\end{tabular}

Mean Desirability Rating $=5.73$

Earlier responses that the group median response indicated that certification is already required for pre-school teachers. Later responses indicated that funding associated with this event would not likely be made available and that, given the number of private pre-schools, "the public is not excited about (pre-school) certification."

Event 46 projected that "Schools will increasingly become involved with other agencies in 
solving the problems of society." Time, impact, and desirability data were as follows:

Time Frame Frequency Distribution

\begin{tabular}{|l|c|c|c|c|c|c|c|}
\hline & $\mathrm{N}$ & $\begin{array}{c}1999- \\
2000\end{array}$ & $\begin{array}{c}2001- \\
2010\end{array}$ & $\begin{array}{c}2011- \\
2020\end{array}$ & $\begin{array}{c}\text { After } \\
2020\end{array}$ & Never & NR \\
\hline Round 2 & 43 & 4 & 30 & 5 & 1 & 2 & 1 \\
\hline Round 3 & 42 & 0 & 38 & 1 & 1 & 2 & 0 \\
\hline
\end{tabular}

\section{$\underline{\text { Impact Distribution }}$}

Very Low
\begin{tabular}{|c|c|c|c|c|c|c|}
\hline 1 & 2 & 3 & 4 & 5 & 6 & 7 \\
\hline 0 & 2 & 1 & 10 & 13 & 9 & 7 \\
\hline
\end{tabular}

No Response $=1$

Mean Impact Rating $=5.12$

Desirability Distribution

Very Low
\begin{tabular}{|c|c|c|c|c|c|c|}
\hline 1 & 2 & 3 & 4 & 5 & 6 & 7 \\
\hline 2 & 3 & 2 & 9 & 8 & 6 & 12 \\
\hline
\end{tabular}

No Response $=1$

Mean Desirability Rating $=5.00$

Only one comment was made by a respondent who indicated that this event would never happen - "Just don’t believe it."

Event 47 projected that "There will be an increase in discipline problems and need for alternative education programs." Time, impact, and desirability data were as follows: 
$\underline{\text { Time Frame Frequency Distribution }}$

\begin{tabular}{|l|c|c|c|c|c|c|c|}
\hline & $\mathrm{N}$ & $\begin{array}{c}1999- \\
2000\end{array}$ & $\begin{array}{c}2001- \\
2010\end{array}$ & $\begin{array}{c}2011- \\
2020\end{array}$ & $\begin{array}{c}\text { After } \\
2020\end{array}$ & Never & NR \\
\hline Round 2 & 43 & 15 & 23 & 0 & 2 & 2 & 1 \\
\hline Round 3 & 42 & 7 & 32 & 1 & 0 & 2 & 0 \\
\hline
\end{tabular}

\section{$\underline{\text { Impact Distribution }}$}

Very Low
\begin{tabular}{|c|c|c|c|c|c|c|}
\hline 1 & 2 & 3 & 4 & 5 & 6 & 7 \\
\hline 2 & 0 & 2 & 7 & 14 & 10 & 6 \\
\hline
\end{tabular}

No Response $=2$

Mean Impact Rating $=5.07$

Desirability Distribution

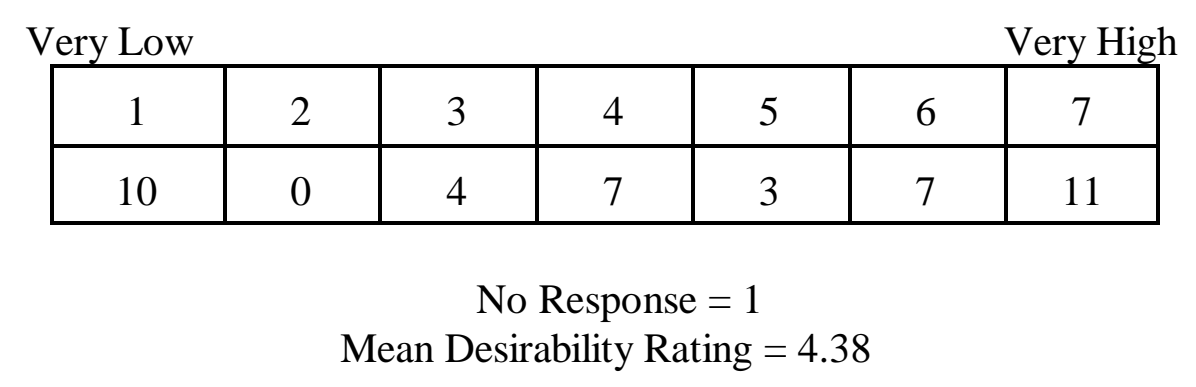

All but one of the respondents who commented felt that this event was already evident and that "with new situations and tragedies public pressure will demand alternative programs." The one respondent who indicated that this event would never occur stated "I hope there will be a decrease in these problems."

Event 48 projected that "Students will be held more accountable for questionable behavior." Time, impact, and desirability data were as follows: 
Time Frame Frequency Distribution

\begin{tabular}{|l|c|c|c|c|c|c|c|}
\hline & $\mathrm{N}$ & $\begin{array}{c}1999- \\
2000\end{array}$ & $\begin{array}{c}2001- \\
2010\end{array}$ & $\begin{array}{c}2011- \\
2020\end{array}$ & $\begin{array}{c}\text { After } \\
2020\end{array}$ & Never & NR \\
\hline Round 2 & 43 & 10 & 29 & 3 & 0 & 1 & 0 \\
\hline Round 3 & 42 & 4 & 37 & 0 & 0 & 1 & 0 \\
\hline
\end{tabular}

\section{$\underline{\text { Impact Distribution }}$}

Very Low
\begin{tabular}{|c|c|c|c|c|c|c|}
\hline 1 & 2 & 3 & 4 & 5 & 6 & 7 \\
\hline 1 & 0 & 3 & 9 & 4 & 15 & 11 \\
\hline
\end{tabular}

Mean Impact Rating $=5.42$

Desirability Distribution

Very Low
\begin{tabular}{|c|c|c|c|c|c|c|}
\hline 1 & 2 & 3 & 4 & 5 & 6 & 7 \\
\hline 1 & 0 & 1 & 4 & 2 & 9 & 26 \\
\hline
\end{tabular}

Mean Desirability Rating $=6.19$

Two of the comments received indicated that this event was already occurring. One respondent who indicated that this event would never occur stated "How would that happen short of removing them from the classroom as we do today?" This respondent further commented that "This is a "family' rather than educational issue."

Event 49 projected that “After-schools programs will expand.” Time, impact, and desirability data were as follows: 
Time Frame Frequency Distribution

\begin{tabular}{|l|c|c|c|c|c|c|c|}
\hline & $\mathrm{N}$ & $\begin{array}{c}1999- \\
2000\end{array}$ & $\begin{array}{c}2001- \\
2010\end{array}$ & $\begin{array}{c}2011- \\
2020\end{array}$ & $\begin{array}{c}\text { After } \\
2020\end{array}$ & Never & NR \\
\hline Round 2 & 43 & 9 & 31 & 0 & 0 & 3 & 0 \\
\hline Round 3 & 42 & 4 & 35 & 0 & 0 & 3 & 0 \\
\hline
\end{tabular}

\section{$\underline{\text { Impact Distribution }}$}

Very Low
\begin{tabular}{|c|c|c|c|c|c|c|}
\hline 1 & 2 & 3 & 4 & 5 & 6 & 7 \\
\hline 1 & 0 & 4 & 9 & 13 & 9 & 7 \\
\hline
\end{tabular}

Mean Impact Rating $=5.05$

Desirability Distribution

Very Low
\begin{tabular}{|c|c|c|c|c|c|c|}
\hline 1 & 2 & 3 & 4 & 5 & 6 & 7 \\
\hline 1 & 0 & 2 & 4 & 9 & 14 & 13 \\
\hline
\end{tabular}

Mean Desirability Rating $=5.65$

Responses in the "1999-2000" time frame indicated that this event was already occurring and that it would continue over several time frames. One respondent indicated that "Increased federal funding is ensuring this will happen." In the "Never" time frame, one respondent reasoned that county school systems, particularly those facing deficits, could not afford such programs.

Event 50 projected that "There will be an increasing emphasis on foreign language programs." Time, impact, and desirability data were as follows: 
$\underline{\text { Time Frame Frequency Distribution }}$

\begin{tabular}{|l|c|c|c|c|c|c|c|}
\hline & $\mathrm{N}$ & $\begin{array}{c}1999- \\
2000\end{array}$ & $\begin{array}{c}2001- \\
2010\end{array}$ & $\begin{array}{c}2011- \\
2020\end{array}$ & $\begin{array}{c}\text { After } \\
2020\end{array}$ & Never & NR \\
\hline Round 2 & 43 & 6 & 25 & 9 & 0 & 2 & 1 \\
\hline Round 3 & 42 & 3 & 36 & 1 & 0 & 2 & 0 \\
\hline
\end{tabular}

\section{$\underline{\text { Impact Distribution }}$}

Very Low
\begin{tabular}{|c|c|c|c|c|c|c|}
\hline 1 & 2 & 3 & 4 & 5 & 6 & 7 \\
\hline 0 & 1 & 6 & 9 & 14 & 9 & 3 \\
\hline
\end{tabular}

$$
\begin{gathered}
\text { No Response }=1 \\
\text { Mean Impact Rating }=4.79
\end{gathered}
$$

$\underline{\text { Desirability Distribution }}$

\begin{tabular}{l} 
Very Low \\
\begin{tabular}{|c|c|c|c|c|c|c|}
\hline 1 & 2 & 3 & 4 & 5 & 6 & 7 \\
\hline 0 & 1 & 7 & 6 & 8 & 12 & 8 \\
\hline
\end{tabular} \\
Mean Desponse $=1$ \\
\hline
\end{tabular}

Respondents who indicated that this event would occur in the "1999-2000" time frame related that it is "already happening" and will continue to evolve over several time frames. One respondent who indicated that this event would never occur stated "English becomes the international language."5

Event 52 projected that "Schools will emphasize more cultural programming (art, music, theater)." Time, impact, and desirability data were as follows: 
Time Frame Frequency Distribution

\begin{tabular}{|l|c|c|c|c|c|c|c|}
\hline & $\mathrm{N}$ & $\begin{array}{c}1999- \\
2000\end{array}$ & $\begin{array}{c}2001- \\
2010\end{array}$ & $\begin{array}{c}2011- \\
2020\end{array}$ & $\begin{array}{c}\text { After } \\
2020\end{array}$ & Never & NR \\
\hline Round 2 & 43 & 0 & 21 & 14 & 1 & 6 & 1 \\
\hline Round 3 & 42 & 0 & 32 & 5 & 2 & 3 & 0 \\
\hline
\end{tabular}

\section{$\underline{\text { Impact Distribution }}$}

Very Low
\begin{tabular}{|c|c|c|c|c|c|c|}
\hline 1 & 2 & 3 & 4 & 5 & 6 & 7 \\
\hline 0 & 3 & 8 & 9 & 12 & 6 & 4 \\
\hline
\end{tabular}

No Response $=1$

Mean Impact Rating $=4.52$

Desirability Distribution

Very Low
\begin{tabular}{|c|c|c|c|c|c|c|}
\hline 1 & 2 & 3 & 4 & 5 & 6 & 7 \\
\hline 0 & 3 & 4 & 10 & 8 & 9 & 8 \\
\hline
\end{tabular}
No Response $=1$
Mean Desirability Rating $=4.95$

All respondents who commented viewed this event as occurring later than the median group response. Respondents from the "2011-2020" and the "After 2020" time frames cited lack of funding and the current emphasis on basic skills as reasons delaying this event. One respondent stated the event would never occur because "There is simply not the public perception that these things are important."

Event 53 projected that "Schools will serve as centers for health, social and recreational 
services and academic support." Time, impact, and desirability data were as follows:

\section{Time Frame Frequency Distribution}

\begin{tabular}{|l|c|c|c|c|c|c|c|}
\hline & $\mathrm{N}$ & $\begin{array}{c}1999- \\
2000\end{array}$ & $\begin{array}{c}2001- \\
2010\end{array}$ & $\begin{array}{c}2011- \\
2020\end{array}$ & $\begin{array}{c}\text { After } \\
2020\end{array}$ & Never & NR \\
\hline Round 2 & 43 & 1 & 23 & 11 & 3 & 3 & 2 \\
\hline Round 3 & 42 & 1 & 35 & 3 & 1 & 1 & 1 \\
\hline
\end{tabular}

\section{Impact Distribution}

Very Low
\begin{tabular}{|c|c|c|c|c|c|c|}
\hline 1 & 2 & 3 & 4 & 5 & 6 & 7 \\
\hline 2 & 0 & 1 & 7 & 18 & 7 & 6 \\
\hline
\end{tabular}

No Response $=2$

Mean Impact Rating $=5.05$

\section{Desirability Distribution}

Very Low
\begin{tabular}{|c|c|c|c|c|c|c|}
\hline 1 & 2 & 3 & 4 & 5 & 6 & 7 \\
\hline 3 & 0 & 2 & 4 & 11 & 13 & 8 \\
\hline
\end{tabular}

No Response $=2$

Mean Desirability Rating $=5.22$

Only two comments were received for this event. The earlier response indicated that public schools were used for these purposes. The later response cited the slow change in organizational structures as delaying the event until 2011-2020.

Event 55 projected that "Closer relationships between the public schools and institutions 
of higher education will form to increase accessibility of public education." Time, impact, and desirability data were as follows:

$\underline{\text { Time Frame Frequency Distribution }}$

\begin{tabular}{|l|c|c|c|c|c|c|c|}
\hline & $\mathrm{N}$ & $\begin{array}{c}1999- \\
2000\end{array}$ & $\begin{array}{c}2001- \\
2010\end{array}$ & $\begin{array}{c}2011- \\
2020\end{array}$ & $\begin{array}{c}\text { After } \\
2020\end{array}$ & Never & NR \\
\hline Round 2 & 43 & 4 & 26 & 8 & 3 & 2 & 0 \\
\hline Round 3 & 42 & 2 & 31 & 4 & 3 & 1 & 1 \\
\hline
\end{tabular}

$\underline{\text { Impact Distribution }}$

Very Low
\begin{tabular}{|c|c|c|c|c|c|c|}
\hline 1 & 2 & 3 & 4 & 5 & 6 & 7 \\
\hline 0 & 0 & 1 & 7 & 10 & 11 & 13 \\
\hline
\end{tabular}

No Response $=1$

Mean Impact Rating $=5.67$

Desirability Distribution

Very Low
\begin{tabular}{|c|c|c|c|c|c|c|}
\hline 1 & 2 & 3 & 4 & 5 & 6 & 7 \\
\hline 0 & 0 & 0 & 5 & 2 & 12 & 22 \\
\hline
\end{tabular}

No Response $=2$

Mean Desirability Rating $=6.24$

Respondents in the "1999-2000" time frame viewed cooperation between public school and higher education as a long process which has already begun. One respondent stated that "SB300 encourages communication between higher education and public education." Later 
responses indicated "too many turf issues" exist and that competition for funds and recognition would impede this event. One respondent from the "2011-2020" time frame stated "It is difficult to move higher education let alone quickly."

Event 59 projected that "There will be a decrease in the number of local school levies." Time, impact, and desirability data were as follows:

\section{Time Frame Frequency Distribution}

\begin{tabular}{|l|c|c|c|c|c|c|c|}
\hline & $\mathrm{N}$ & $\begin{array}{c}1999- \\
2000\end{array}$ & $\begin{array}{c}2001- \\
2010\end{array}$ & $\begin{array}{c}2011- \\
2020\end{array}$ & $\begin{array}{c}\text { After } \\
2020\end{array}$ & Never & NR \\
\hline Round 2 & 43 & 8 & 24 & 6 & 1 & 3 & 1 \\
\hline Round 3 & 42 & 7 & 30 & 2 & 0 & 2 & 1 \\
\hline
\end{tabular}

\section{$\underline{\text { Impact Distribution }}$}

Very Low
\begin{tabular}{|c|c|c|c|c|c|c|}
\hline 1 & 2 & 3 & 4 & 5 & 6 & 7 \\
\hline 1 & 0 & 2 & 3 & 8 & 10 & 18 \\
\hline
\end{tabular}

No Response $=1$

Mean Impact Rating $=5.83$

\section{Desirability Distribution}

Very Low
\begin{tabular}{|c|c|c|c|c|c|c|}
\hline 1 & 2 & 3 & 4 & 5 & 6 & 7 \\
\hline 20 & 3 & 6 & 2 & 4 & 4 & 3 \\
\hline
\end{tabular}

No Response $=1$

Mean Desirability Rating $=2.79$ 
Respondents in the "1999-2000" time frame indicated that with several levies up for renewal this year, some would likely fail. One respondent commented "Some may fail this year, as long as equity $\$$ are provided. What a disincentive for passing levies! We have gone from 44 to 42 counties in recent years." Those responding in the "2011-2020" time frame indicated that "With the current finance system, local school levies are needed." Another cautioned that the Recht litigation resolution may require a statewide excess levy. The respondent from the "Never" category stated "The increase in state personal and income taxes this would mean makes it unlikely."

Event 61 projected that "There will be a major revision to the school-aid formula." Time, impact, and desirability data were as follows:

Time Frame Frequency Distribution

\begin{tabular}{|l|c|c|c|c|c|c|c|}
\hline & $\mathrm{N}$ & $\begin{array}{c}1999- \\
2000\end{array}$ & $\begin{array}{c}2001- \\
2010\end{array}$ & $\begin{array}{c}2011- \\
2020\end{array}$ & $\begin{array}{c}\text { After } \\
2020\end{array}$ & Never & NR \\
\hline Round 2 & 43 & 4 & 36 & 2 & 0 & 0 & 1 \\
\hline Round 3 & 42 & 2 & 38 & 1 & 0 & 1 & 0 \\
\hline
\end{tabular}

\section{Impact Distribution}

Very Low
\begin{tabular}{|c|c|c|c|c|c|c|}
\hline 1 & 2 & 3 & 4 & 5 & 6 & 7 \\
\hline 0 & 0 & 0 & 8 & 4 & 14 & 16 \\
\hline
\end{tabular}

No Response $=1$

Mean Impact Rating $=5.90$ 


\section{Desirability Distribution}

Very Low
\begin{tabular}{|c|c|c|c|c|c|c|}
\hline 1 & 2 & 3 & 4 & 5 & 6 & 7 \\
\hline 1 & 2 & 0 & 6 & 8 & 9 & 10 \\
\hline
\end{tabular}

No Response $=1$

Mean Desirability Rating $=5.60$

The earlier respondent indicated that such revision would take several time frames to evolve.

Event 62 projected that "Funding for a new formula will be provided by general revenue sources, not property taxes." Time, impact, and desirability data were as follows:

\section{Time Frame Frequency Distribution}

\begin{tabular}{|l|c|c|c|c|c|c|c|}
\hline & $\mathrm{N}$ & $\begin{array}{c}1999- \\
2000\end{array}$ & $\begin{array}{c}2001- \\
2010\end{array}$ & $\begin{array}{c}2011- \\
2020\end{array}$ & $\begin{array}{c}\text { After } \\
2020\end{array}$ & Never & NR \\
\hline Round 2 & 43 & 1 & 27 & 6 & 0 & 8 & 1 \\
\hline Round 3 & 42 & 0 & 32 & 4 & 1 & 4 & 1 \\
\hline
\end{tabular}

\section{Impact Distribution}

Very Low
\begin{tabular}{|c|c|c|c|c|c|c|}
\hline 1 & 2 & 3 & 4 & 5 & 6 & 7 \\
\hline 1 & 1 & 1 & 2 & 16 & 11 & 8 \\
\hline
\end{tabular}

No Response $=3$

Mean Impact Rating $=5.40$ 


\section{Desirability Distribution}

Very Low
\begin{tabular}{|c|c|c|c|c|c|c|}
\hline 1 & 2 & 3 & 4 & 5 & 6 & 7 \\
\hline 2 & 0 & 0 & 4 & 13 & 12 & 9 \\
\hline
\end{tabular}

No Response $=3$

Mean Desirability Rating $=5.45$

All comments received were for occurrence later than the median group response. Those answering from "2011-2020" indicated that the tax system would have to be revised first, which would take time, and that since "both (general and property tax) will continue as sources, the ratio will change." The respondent from the "After 2020" category felt that "Experiences in other states have not been good at this date - maybe in long term." The respondent from the "Never" category stated that "There is simply not the public perception that these things are important."

Event 63 projected that "Advertising in the schools and sponsorship of athletic teams will begin." Time, impact, and desirability data were as follows:

Time Frame Frequency Distribution

\begin{tabular}{|l|c|c|c|c|c|c|c|}
\hline & $\mathrm{N}$ & $\begin{array}{c}1999- \\
2000\end{array}$ & $\begin{array}{c}2001- \\
2010\end{array}$ & $\begin{array}{c}2011- \\
2020\end{array}$ & $\begin{array}{c}\text { After } \\
2020\end{array}$ & Never & NR \\
\hline Round 2 & 43 & 2 & 22 & 8 & 1 & 10 & 0 \\
\hline Round 3 & 42 & 1 & 34 & 2 & 0 & 5 & 0 \\
\hline
\end{tabular}




\section{Impact Distribution}

Very Low
\begin{tabular}{|c|c|c|c|c|c|c|}
\hline 1 & 2 & 3 & 4 & 5 & 6 & 7 \\
\hline 5 & 4 & 6 & 6 & 9 & 8 & 5 \\
\hline
\end{tabular}

Mean Impact Rating $=4.26$

\section{Desirability Distribution}

Very Low
\begin{tabular}{|c|c|c|c|c|c|c|}
\hline 1 & 2 & 3 & 4 & 5 & 6 & 7 \\
\hline 15 & 12 & 5 & 5 & 1 & 4 & 1 \\
\hline
\end{tabular}

Mean Desirability Rating $=2.56$

Earlier responses indicated that this event "Already exists to some degree." Another stated "The sooner the better if it helps students." One respondent claimed that, while at a local school board meeting, he/she learned "of local sponsorship of a high school swim team." Later responses indicated that this degree of commercialism would not be good for public education and would be resisted by both "West Virginians and the Secondary School Athletic Commission." Another stated that "I hope this doesn't happen - however, money talks."

Event 65 projected that "Staff development will require paid additional/extended days for teachers." Time, impact, and desirability data were as follows: 
$\underline{\text { Time Frame Frequency Distribution }}$

\begin{tabular}{|l|c|c|c|c|c|c|c|}
\hline & $\mathrm{N}$ & $\begin{array}{c}1999- \\
2000\end{array}$ & $\begin{array}{c}2001- \\
2010\end{array}$ & $\begin{array}{c}2011- \\
2020\end{array}$ & $\begin{array}{c}\text { After } \\
2020\end{array}$ & Never & NR \\
\hline Round 2 & 43 & 3 & 30 & 2 & 1 & 7 & 0 \\
\hline Round 3 & 42 & 0 & 36 & 1 & 0 & 5 & 0 \\
\hline
\end{tabular}

$\underline{\text { Impact Distribution }}$

Very Low

\begin{tabular}{|c|c|c|c|c|c|c|}
\hline 1 & 2 & 3 & 4 & 5 & 6 & 7 \\
\hline 2 & 0 & 1 & 9 & 8 & 11 & 10 \\
\hline
\end{tabular}

No Response $=2$

Mean Impact Rating $=5.29$

Desirability Distribution

Very Low
\begin{tabular}{|c|c|c|c|c|c|c|}
\hline 1 & 2 & 3 & 4 & 5 & 6 & 7 \\
\hline 2 & 3 & 4 & 4 & 3 & 8 & 17 \\
\hline
\end{tabular}

No Response $=2$

Mean Desirability Rating $=5.32$

Only one comment was received which indicated that this event would never occur. The respondent commented that "More collaboration required, but not additional time."

Event 67 projected that "There will be more federal funding and more federal control." Time, impact, and desirability data were as follows: 
$\underline{\text { Time Frame Frequency Distribution }}$

\begin{tabular}{|l|c|c|c|c|c|c|c|}
\hline & $\mathrm{N}$ & $\begin{array}{c}1999- \\
2000\end{array}$ & $\begin{array}{c}2001- \\
2010\end{array}$ & $\begin{array}{c}2011- \\
2020\end{array}$ & $\begin{array}{c}\text { After } \\
2020\end{array}$ & Never & NR \\
\hline Round 2 & 43 & 2 & 20 & 9 & 1 & 9 & 2 \\
\hline Round 3 & 42 & 1 & 30 & 4 & 0 & 6 & 1 \\
\hline
\end{tabular}

\section{$\underline{\text { Impact Distribution }}$}

Very Low
\begin{tabular}{|c|c|c|c|c|c|c|}
\hline 1 & 2 & 3 & 4 & 5 & 6 & 7 \\
\hline 0 & 2 & 1 & 6 & 14 & 7 & 8 \\
\hline
\end{tabular}

No Response $=5$

Mean Impact Rating $=5.24$

Desirability Distribution

Very Low
\begin{tabular}{|c|c|c|c|c|c|c|}
\hline 1 & 2 & 3 & 4 & 5 & 6 & 7 \\
\hline 13 & 9 & 8 & 4 & 0 & 3 & 1 \\
\hline
\end{tabular}

No Response $=5$

Mean Desirability Rating $=2.53$

Four comments were received for this event. One respondent indicated that the event would not occur until the "2011-2020" time frame because the "Feds don't want in on a problem they can call a state responsibility." Two panelists indicated that the event would never happen because the "Trend is the other way under 2 terms of GOP leadership beginning in 2001" and increases would be "sporadic." The third respondent, who did not chose a time frame, stated that the "Percentage of state education budget from federal funds will remain constant, total dollars 
increase however."

Event 69 projected that "A voucher system of some sort will occur." Time, impact, and desirability data were as follows:

Time Frame Frequency Distribution

\begin{tabular}{|l|c|c|c|c|c|c|c|}
\hline & $\mathrm{N}$ & $\begin{array}{c}1999- \\
2000\end{array}$ & $\begin{array}{c}2001- \\
2010\end{array}$ & $\begin{array}{c}2011- \\
2020\end{array}$ & $\begin{array}{c}\text { After } \\
2020\end{array}$ & Never & NR \\
\hline Round 2 & 43 & 1 & 24 & 8 & 2 & 8 & 0 \\
\hline Round 3 & 42 & 0 & 31 & 3 & 1 & 7 & 0 \\
\hline
\end{tabular}

\section{Impact Distribution}

Very Low
\begin{tabular}{|c|c|c|c|c|c|c|}
\hline 1 & 2 & 3 & 4 & 5 & 6 & 7 \\
\hline 1 & 0 & 2 & 6 & 6 & 11 & 16 \\
\hline
\end{tabular}

No Response $=1$

Mean Impact Rating $=5.69$

\section{Desirability Distribution}

Very Low
\begin{tabular}{|c|c|c|c|c|c|c|}
\hline 1 & 2 & 3 & 4 & 5 & 6 & 7 \\
\hline 23 & 4 & 3 & 5 & 2 & 4 & 2 \\
\hline
\end{tabular}

Mean Desirability Rating $=2.51$

Two respondents indicated that this event would occur in "2011-2020." One stated that the idea of vouchers was "Still a politically hot potato" while the other noted that there was "still a lot of support for public schools." All other respondents thought the event would never occur. 
Their reasons included legislative hesitance to support vouchers, the number of issues that would need to be resolved, resistance from the middle class who "will not allow dollars to be diverted to the rich." One respondent noted that the schools and the Democratic party opposes vouchers because "this is a state right and WV is Democratic." One respondent added that "We don't need this as long as the public education system does its job."

Event 70 projected that "Public school choice will be enacted." Time, impact, and desirability data were as follows:

Time Frame Frequency Distribution

\begin{tabular}{|l|c|c|c|c|c|c|c|}
\hline & $\mathrm{N}$ & $\begin{array}{c}1999- \\
2000\end{array}$ & $\begin{array}{c}2001- \\
2010\end{array}$ & $\begin{array}{c}2011- \\
2020\end{array}$ & $\begin{array}{c}\text { After } \\
2020\end{array}$ & Never & NR \\
\hline Round 2 & 43 & 0 & 26 & 11 & 2 & 2 & 2 \\
\hline Round 3 & 42 & 0 & 33 & 7 & 0 & 1 & 1 \\
\hline
\end{tabular}

$\underline{\text { Impact Distribution }}$

Very Low
\begin{tabular}{|c|c|c|c|c|c|c|}
\hline 1 & 2 & 3 & 4 & 5 & 6 & 7 \\
\hline 0 & 0 & 1 & 3 & 9 & 14 & 14 \\
\hline
\end{tabular}

No Response $=2$

Mean Impact Rating $=5.90$ 


\section{Desirability Distribution}

Very Low
\begin{tabular}{|c|c|c|c|c|c|c|}
\hline 1 & 2 & 3 & 4 & 5 & 6 & 7 \\
\hline 11 & 6 & 3 & 4 & 6 & 7 & 4 \\
\hline
\end{tabular}

No Response $=2$

Mean Desirability Rating $=3.61$

All responses except one fell in the "2011-2020" time frame. One respondent stated that this issue was "still in courts" while another indicated that this was "already being done without statute." One respondent did not chose a time frame because he/she felt that "choice needs to be defined."

Event 71 projected that "Charter school legislation will be adopted in WV."

Time Frame Frequency Distribution

\begin{tabular}{|l|c|c|c|c|c|c|c|}
\hline & $\mathrm{N}$ & $\begin{array}{c}1999- \\
2000\end{array}$ & $\begin{array}{c}2001- \\
2010\end{array}$ & $\begin{array}{c}2011- \\
2020\end{array}$ & $\begin{array}{c}\text { After } \\
2020\end{array}$ & Never & NR \\
\hline Round 2 & 43 & 2 & 29 & 4 & 0 & 7 & 1 \\
\hline Round 3 & 42 & 0 & 37 & 1 & 0 & 4 & 0 \\
\hline
\end{tabular}

$\underline{\text { Impact Distribution }}$

Very Low
\begin{tabular}{|c|c|c|c|c|c|c|}
\hline 1 & 2 & 3 & 4 & 5 & 6 & 7 \\
\hline 1 & 1 & 3 & 7 & 9 & 8 & 12 \\
\hline
\end{tabular}

No Response $=2$

Mean Impact Rating $=5.29$ 


\section{Desirability Distribution}

Very Low
\begin{tabular}{|c|c|c|c|c|c|c|}
\hline 1 & 2 & 3 & 4 & 5 & 6 & 7 \\
\hline 13 & 8 & 4 & 7 & 2 & 4 & 3 \\
\hline
\end{tabular}

No Response $=2$

Mean Desirability Rating $=3.02$

All minority responses indicated that this event would never occur. Comments included the idea that "quasi-charter schools" already exist within the state, and that "If this occurs, it will come from the federal level." One respondent felt that charter schools would not be necessary "as long as the public education system does its job."

Event 72 projected that "Private schools will increase in number." Time, impact, and desirability data were as follows:

Time Frame Frequency Distribution

\begin{tabular}{|l|c|c|c|c|c|c|c|}
\hline & $\mathrm{N}$ & $\begin{array}{c}1999- \\
2000\end{array}$ & $\begin{array}{c}2001- \\
2010\end{array}$ & $\begin{array}{c}2011- \\
2020\end{array}$ & $\begin{array}{c}\text { After } \\
2020\end{array}$ & Never & NR \\
\hline Round 2 & 43 & 2 & 28 & 5 & 0 & 7 & 1 \\
\hline Round 3 & 42 & 1 & 35 & 2 & 0 & 4 & 0 \\
\hline
\end{tabular}

Impact Distribution

Very Low
\begin{tabular}{|c|c|c|c|c|c|c|}
\hline 1 & 2 & 3 & 4 & 5 & 6 & 7 \\
\hline 1 & 2 & 2 & 13 & 9 & 6 & 8 \\
\hline
\end{tabular}

No Response $=2$

Mean Impact Rating $=4.88$ 


\section{Desirability Distribution}

Very Low
\begin{tabular}{|c|c|c|c|c|c|c|}
\hline 1 & 2 & 3 & 4 & 5 & 6 & 7 \\
\hline 12 & 12 & 7 & 4 & 3 & 2 & 2 \\
\hline
\end{tabular}

No Response $=1$

Mean Desirability Rating $=2.71$

One respondent viewed this event as occurring in the "1999-2000" time frame and noted that "Several (private schools) under construction now. Charleston, Huntington, Morgantown, Beckley." Three respondents indicated that this event would never occur. One mentioned that private schools would be unnecessary if "the public education system does its job." Two respondents mentioned cost factors with one noting "Income of state households cannot support more private schools."

Event 76 projected that "Facilities construction will become more and more a state function rather than a county function." Time, impact, and desirability data were as follows:

Time Frame Frequency Distribution

\begin{tabular}{|l|c|c|c|c|c|c|c|}
\hline & $\mathrm{N}$ & $\begin{array}{c}1999- \\
2000\end{array}$ & $\begin{array}{c}2001- \\
2010\end{array}$ & $\begin{array}{c}2011- \\
2020\end{array}$ & $\begin{array}{c}\text { After } \\
2020\end{array}$ & Never & NR \\
\hline Round 2 & 43 & 4 & 27 & 6 & 0 & 5 & 1 \\
\hline Round 3 & 42 & 2 & 37 & 2 & 0 & 1 & 0 \\
\hline
\end{tabular}




\section{Impact Distribution}

Very Low
\begin{tabular}{|c|c|c|c|c|c|c|}
\hline 1 & 2 & 3 & 4 & 5 & 6 & 7 \\
\hline 0 & 1 & 1 & 10 & 6 & 11 & 11 \\
\hline
\end{tabular}

No Response $=3$

Mean Impact Rating $=5.45$

\section{Desirability Distribution}

Very Low
\begin{tabular}{|c|c|c|c|c|c|c|}
\hline 1 & 2 & 3 & 4 & 5 & 6 & 7 \\
\hline 2 & 4 & 3 & 11 & 5 & 4 & 11 \\
\hline
\end{tabular}

No Response $=3$

Mean Desirability Rating $=4.73$

One respondent indicated that this event would occur in the "1999-2000" time frame and stated "I think we've been there since the SBA was formed and funding provided!" Another respondent indicated the event would never happen because "There is simply not the public perception that these things are important."

Event 77 projected that "School consolidation will continue, but will slow down." Time, impact, and desirability data were as follows:

Time Frame Frequency Distribution

\begin{tabular}{|l|c|c|c|c|c|c|c|}
\hline & $\mathrm{N}$ & $\begin{array}{c}1999- \\
2000\end{array}$ & $\begin{array}{c}2001- \\
2010\end{array}$ & $\begin{array}{c}2011- \\
2020\end{array}$ & $\begin{array}{c}\text { After } \\
2020\end{array}$ & Never & NR \\
\hline Round 2 & 43 & 10 & 28 & 1 & 3 & 0 & 1 \\
\hline Round 3 & 42 & 5 & 36 & 1 & 0 & 0 & 0 \\
\hline
\end{tabular}




\section{Impact Distribution}

Very Low
\begin{tabular}{|c|c|c|c|c|c|c|}
\hline 1 & 2 & 3 & 4 & 5 & 6 & 7 \\
\hline 0 & 1 & 3 & 15 & 11 & 6 & 6 \\
\hline
\end{tabular}

No Response $=1$

Mean Impact Rating $=4.86$

\section{Desirability Distribution}

Very Low
\begin{tabular}{|c|c|c|c|c|c|c|}
\hline 1 & 2 & 3 & 4 & 5 & 6 & 7 \\
\hline 1 & 2 & 1 & 18 & 6 & 5 & 9 \\
\hline
\end{tabular}

No Response $=1$

Mean Desirability Rating $=4.83$

The three respondents who commented all agreed that this event would occur in the "1999-2000" time frame. Several stated that this has already begun due, in part, to "fights in rural counties." One respondent noted that the event "Assumes continued declining student population."

Event 78 projected that "Schools will become larger." Time, impact, and desirability data were as follows:

Time Frame Frequency Distribution

\begin{tabular}{|l|c|c|c|c|c|c|c|}
\hline & $\mathrm{N}$ & $\begin{array}{c}1999- \\
2000\end{array}$ & $\begin{array}{c}2001- \\
2010\end{array}$ & $\begin{array}{c}2011- \\
2020\end{array}$ & $\begin{array}{c}\text { After } \\
2020\end{array}$ & Never & NR \\
\hline Round 2 & 43 & 8 & 24 & 4 & 2 & 4 & 1 \\
\hline Round 3 & 42 & 4 & 33 & 0 & 1 & 4 & 0 \\
\hline
\end{tabular}




\title{
Impact Distribution
}

Very Low
\begin{tabular}{|c|c|c|c|c|c|c|}
\hline 1 & 2 & 3 & 4 & 5 & 6 & 7 \\
\hline 1 & 4 & 3 & 10 & 13 & 6 & 5 \\
\hline
\end{tabular}

\author{
No Response $=1$ \\ Mean Impact Rating $=4.62$
}

Desirability Distribution

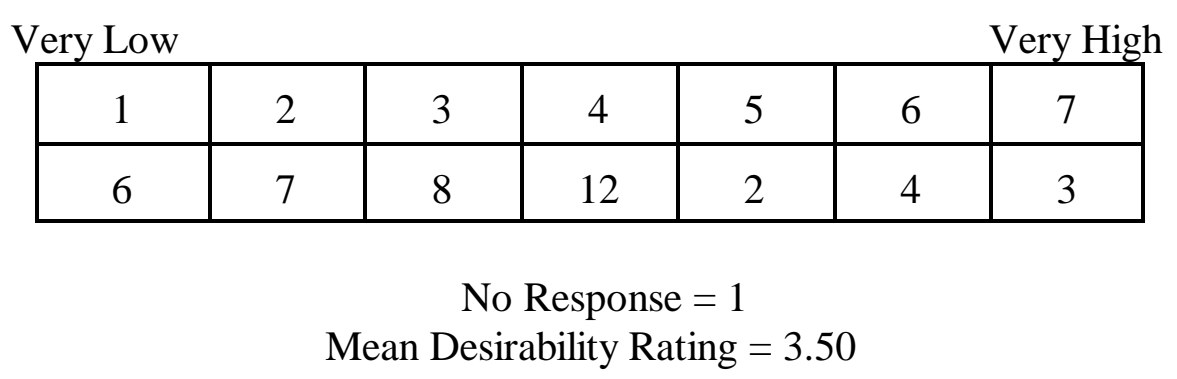

Earlier responses indicated that schools have already become larger. One panelist stated "Our largest high school is smaller than the largest of 10, 20 and 30 years ago." Another indicated that this has been occurring "ever since the economy-of-scale and the SBA arrived." One respondent felt that the event would fall in the "After 2020" category and mentioned that its occurrence would require a significant drop or gain in student population. Several respondents who said the event would never occur indicated that the trend may revert back to smaller schools. One stated "I simply see signs that people are beginning to feel that bigger is not necessarily better and that there is an optimal size for schools." Another stated "I suppose in some areas this will happen, but I think the bulk of consolidation is behind us. With charter schools, vouchers, computerized instruction, etc., I see the trend going smaller."

Event 79 projected that "There will be a continued move to middle school concept." 
Time, impact, and desirability data were as follows:

Time Frame Frequency Distribution

\begin{tabular}{|l|c|c|c|c|c|c|c|}
\hline & $\mathrm{N}$ & $\begin{array}{c}1999- \\
2000\end{array}$ & $\begin{array}{c}2001- \\
2010\end{array}$ & $\begin{array}{c}2011- \\
2020\end{array}$ & $\begin{array}{c}\text { After } \\
2020\end{array}$ & Never & NR \\
\hline Round 2 & 43 & 13 & 25 & 2 & 0 & 2 & 1 \\
\hline Round 3 & 42 & 6 & 36 & 0 & 0 & 0 & 0 \\
\hline
\end{tabular}

\section{Impact Distribution}

Very Low
\begin{tabular}{|c|c|c|c|c|c|c|}
\hline 1 & 2 & 3 & 4 & 5 & 6 & 7 \\
\hline 3 & 2 & 2 & 13 & 14 & 7 & 1 \\
\hline
\end{tabular}

No Response $=1$

Mean Impact Rating $=4.38$

Desirability Distribution

Very Low
\begin{tabular}{|c|c|c|c|c|c|c|}
\hline 1 & 2 & 3 & 4 & 5 & 6 & 7 \\
\hline 5 & 1 & 3 & 8 & 8 & 10 & 7 \\
\hline
\end{tabular}

No Response $=1$

Mean Desirability Rating $=4.69$

All minority respondents predicted that this event would occur in the "1999-2000" time

frame. Comments indicated that the event would occur over several time frames based on demographic changes and previous school consolidations.

Event 80 projected that "Counties with rapidly increasing enrollments will experience 
financial and political problems in providing facilities and quality staff." Time, impact, and desirability data were as follows:

Time Frame Frequency Distribution

\begin{tabular}{|l|c|c|c|c|c|c|c|}
\hline & $\mathrm{N}$ & $\begin{array}{c}1999- \\
2000\end{array}$ & $\begin{array}{c}2001- \\
2010\end{array}$ & $\begin{array}{c}2011- \\
2020\end{array}$ & $\begin{array}{c}\text { After } \\
2020\end{array}$ & Never & NR \\
\hline Round 2 & 43 & 12 & 21 & 2 & 0 & 4 & 4 \\
\hline Round 3 & 42 & 8 & 31 & 1 & 0 & 1 & 1 \\
\hline
\end{tabular}

\section{Impact Distribution}

Very Low
\begin{tabular}{|c|c|c|c|c|c|c|}
\hline 1 & 2 & 3 & 4 & 5 & 6 & 7 \\
\hline 0 & 0 & 2 & 3 & 9 & 13 & 10 \\
\hline
\end{tabular}

No Response $=6$

Mean Impact Rating $=5.70$

\section{Desirability Distribution}

Very Low
\begin{tabular}{|c|c|c|c|c|c|c|}
\hline 1 & 2 & 3 & 4 & 5 & 6 & 7 \\
\hline 20 & 8 & 3 & 3 & 0 & 2 & 0 \\
\hline
\end{tabular}

No Response $=7$

Mean Desirability Rating $=1.92$

Four respondents indicated that this event was already occurring. Once stated that

"Putnam and Jefferson/Berkeley (counties) have been in this situation for some time." Another mentioned that this would occur "next year if state is affected by world economic problems." One 
respondent indicated that the event would never occur because "The Legislature fully funded the allowance for increased enrollment for the first time this year."

Event 81 projected that "Federal government will provide funding for replacement of aging school buildings." Time, impact, and desirability data were as follows:

Time Frame Frequency Distribution

\begin{tabular}{|l|c|c|c|c|c|c|c|}
\hline & $\mathrm{N}$ & $\begin{array}{c}1999- \\
2000\end{array}$ & $\begin{array}{c}2001- \\
2010\end{array}$ & $\begin{array}{c}2011- \\
2020\end{array}$ & $\begin{array}{c}\text { After } \\
2020\end{array}$ & Never & NR \\
\hline Round 2 & 43 & 3 & 17 & 5 & 2 & 13 & 3 \\
\hline Round 3 & 42 & 2 & 29 & 3 & 1 & 7 & 0 \\
\hline
\end{tabular}

$\underline{\text { Impact Distribution }}$

Very Low
\begin{tabular}{|c|c|c|c|c|c|c|}
\hline 1 & 2 & 3 & 4 & 5 & 6 & 7 \\
\hline 0 & 2 & 3 & 6 & 8 & 9 & 9 \\
\hline
\end{tabular}

No Response $=6$

Mean Impact Rating $=5.24$

Desirability Distribution

Very Low
\begin{tabular}{|c|c|c|c|c|c|c|}
\hline 1 & 2 & 3 & 4 & 5 & 6 & 7 \\
\hline 2 & 3 & 4 & 2 & 5 & 9 & 12 \\
\hline
\end{tabular}

No Response $=6$

Mean Desirability Rating $=5.16$

Two responses were received from the "1999-2000" category. One indicated that such 
fund would be "more likely to occur with Clinton as president" and would continue through the "2001-2010" time frame. The other comment agreed that this would occur, but indicated that other educational programs would be more attractive to the federal government. Later responses were based on lack of funding caused by competition form social security and Medicare.

Event 82 projected that "Indoor air quality will be legislated for all new schools." Time, impact, and desirability data were as follows:

Time Frame Frequency Distribution

\begin{tabular}{|l|c|c|c|c|c|c|c|}
\hline & $\mathrm{N}$ & $\begin{array}{c}1999- \\
2000\end{array}$ & $\begin{array}{c}2001- \\
2010\end{array}$ & $\begin{array}{c}2011- \\
2020\end{array}$ & $\begin{array}{c}\text { After } \\
2020\end{array}$ & Never & NR \\
\hline Round 2 & 43 & 11 & 25 & 2 & 1 & 1 & 3 \\
\hline Round 3 & 42 & 8 & 32 & 0 & 1 & 0 & 1 \\
\hline
\end{tabular}

Impact Distribution

Very Low
\begin{tabular}{|c|c|c|c|c|c|c|}
\hline 1 & 2 & 3 & 4 & 5 & 6 & 7 \\
\hline 2 & 2 & 4 & 8 & 10 & 4 & 10 \\
\hline
\end{tabular}

No Response $=3$

Mean Impact Rating $=4.85$

Desirability Distribution

Very Low
\begin{tabular}{|c|c|c|c|c|c|c|}
\hline 1 & 2 & 3 & 4 & 5 & 6 & 7 \\
\hline 2 & 5 & 1 & 6 & 5 & 10 & 11 \\
\hline
\end{tabular}

No Response $=3$

Mean Desirability Rating $=5.03$ 
Comments received from the "1999-2000" category indicated that this legislation was currently being drafted. One respondent indicated that this might begin at the federal level and "Federal interest will trickle down to state next year." Two other comments were received from respondents who did not offer a time frame estimate. Both indicated that this was already law.

Event 83 projected that "Radon testing will be legislated for all new schools." Time, impact, and desirability data were as follows:

Time Frame Frequency Distribution

\begin{tabular}{|l|c|c|c|c|c|c|c|}
\hline & $\mathrm{N}$ & $\begin{array}{c}1999- \\
2000\end{array}$ & $\begin{array}{c}2001- \\
2010\end{array}$ & $\begin{array}{c}2011- \\
2020\end{array}$ & $\begin{array}{c}\text { After } \\
2020\end{array}$ & Never & NR \\
\hline Round 2 & 43 & 8 & 27 & 3 & 0 & 2 & 3 \\
\hline Round 3 & 42 & 6 & 34 & 0 & 0 & 1 & 1 \\
\hline
\end{tabular}

$\underline{\text { Impact Distribution }}$

Very Low
\begin{tabular}{|c|c|c|c|c|c|c|}
\hline 1 & 2 & 3 & 4 & 5 & 6 & 7 \\
\hline 4 & 1 & 2 & 14 & 4 & 6 & 8 \\
\hline
\end{tabular}

No Response $=4$

Mean Impact Rating $=4.62$

Desirability Distribution

Very Low
\begin{tabular}{|c|c|c|c|c|c|c|}
\hline 1 & 2 & 3 & 4 & 5 & 6 & 7 \\
\hline 2 & 5 & 1 & 6 & 4 & 9 & 12 \\
\hline
\end{tabular}

No Response $=4$

Mean Desirability Rating $=5.05$ 
All respondents were from the "1999-2000" time frame and indicated that they felt this was already required by law.

Event 85 projected that "Security systems will be installed in all public schools." Time, impact, and desirability data were as follows:

\section{Time Frame Frequency Distribution}

\begin{tabular}{|l|c|c|c|c|c|c|c|}
\hline & $\mathrm{N}$ & $\begin{array}{c}1999- \\
2000\end{array}$ & $\begin{array}{c}2001- \\
2010\end{array}$ & $\begin{array}{c}2011- \\
2020\end{array}$ & $\begin{array}{c}\text { After } \\
2020\end{array}$ & Never & NR \\
\hline Round 2 & 43 & 2 & 22 & 12 & 2 & 5 & 0 \\
\hline Round 3 & 42 & 1 & 31 & 6 & 1 & 3 & 0 \\
\hline
\end{tabular}

\section{Impact Distribution}

Very Low
\begin{tabular}{|c|c|c|c|c|c|c|}
\hline 1 & 2 & 3 & 4 & 5 & 6 & 7 \\
\hline 1 & 1 & 5 & 10 & 10 & 6 & 8 \\
\hline
\end{tabular}

No Response $=2$

Mean Impact Rating $=4.88$

\section{Desirability Distribution}

Very Low
\begin{tabular}{|c|c|c|c|c|c|c|}
\hline 1 & 2 & 3 & 4 & 5 & 6 & 7 \\
\hline 6 & 3 & 4 & 3 & 5 & 7 & 14 \\
\hline
\end{tabular}

No Response $=1$

Mean Desirability Rating $=4.79$

Four respondents who commented indicated that this event would occur in the "2011- 
$2020 "$ time frame. Their primary reason for a delay in the occurrence of the event was lack of funds. One respondent stated that "The current media generated panic will subside as the public concludes that schools are no more unsafe than anywhere else." Those who said that the event would never occur indicated that this did not appear to be a critical issue in West Virginia.

Event 88 projected that "There will be a return to "best qualified," not "most senior," when selecting teachers." Time, impact, and desirability data were as follows:

Time Frame Frequency Distribution

\begin{tabular}{|l|c|c|c|c|c|c|c|}
\hline & $\mathrm{N}$ & $\begin{array}{c}1999- \\
2000\end{array}$ & $\begin{array}{c}2001- \\
2010\end{array}$ & $\begin{array}{c}2011- \\
2020\end{array}$ & $\begin{array}{c}\text { After } \\
2020\end{array}$ & Never & NR \\
\hline Round 2 & 43 & 2 & 19 & 10 & 4 & 7 & 1 \\
\hline Round 3 & 42 & 3 & 24 & 7 & 2 & 6 & 0 \\
\hline
\end{tabular}

Impact Distribution

Very Low
\begin{tabular}{|c|c|c|c|c|c|c|}
\hline 1 & 2 & 3 & 4 & 5 & 6 & 7 \\
\hline 2 & 1 & 0 & 1 & 7 & 11 & 20 \\
\hline
\end{tabular}

No Response $=1$

Mean Impact Rating $=5.93$

Desirability Distribution

Very Low
\begin{tabular}{|c|c|c|c|c|c|c|}
\hline 1 & 2 & 3 & 4 & 5 & 6 & 7 \\
\hline 4 & 1 & 0 & 1 & 2 & 10 & 24 \\
\hline
\end{tabular}

No Response $=1$

Mean Desirability Rating $=5.90$ 
Three respondents indicated that this event was already state law. Those responding in the time frame after the median group response cited the strength of teacher unions and the Legislature in resisting this event.

Event 90 projected that "There will be more flexibility of certification laws to allow for greater mobility to meet staffing demands including interstate and international licensure." Time, impact, and desirability data were as follows:

Time Frame Frequency Distribution

\begin{tabular}{|l|c|c|c|c|c|c|c|}
\hline & $\mathrm{N}$ & $\begin{array}{c}1999- \\
2000\end{array}$ & $\begin{array}{c}2001- \\
2010\end{array}$ & $\begin{array}{c}2011- \\
2020\end{array}$ & $\begin{array}{c}\text { After } \\
2020\end{array}$ & Never & NR \\
\hline Round 2 & 43 & 0 & 28 & 14 & 0 & 1 & 0 \\
\hline Round 3 & 42 & 0 & 37 & 5 & 0 & 0 & 0 \\
\hline
\end{tabular}

Impact Distribution

Very Low
\begin{tabular}{|c|c|c|c|c|c|c|}
\hline 1 & 2 & 3 & 4 & 5 & 6 & 7 \\
\hline 1 & 1 & 3 & 10 & 10 & 9 & 9 \\
\hline
\end{tabular}

Mean Impact Rating $=5.09$

Desirability Distribution

Very Low
\begin{tabular}{|c|c|c|c|c|c|c|}
\hline 1 & 2 & 3 & 4 & 5 & 6 & 7 \\
\hline 3 & 3 & 2 & 4 & 9 & 12 & 10 \\
\hline
\end{tabular}

Mean Desirability Rating $=5.07$ 
One comment was received from the "2011-2020" time frame which indicated that "Interstate and international requirement slows this issue way down!"

Event 91 projected that "Degree programs will be offered for administrators working in finance, transportation, and nutrition service." Time, impact, and desirability data were as follows:

Time Frame Frequency Distribution

\begin{tabular}{|l|c|c|c|c|c|c|c|}
\hline & $\mathrm{N}$ & $\begin{array}{c}1999- \\
2000\end{array}$ & $\begin{array}{c}2001- \\
2010\end{array}$ & $\begin{array}{c}2011- \\
2020\end{array}$ & $\begin{array}{c}\text { After } \\
2020\end{array}$ & Never & NR \\
\hline Round 2 & 43 & 1 & 22 & 13 & 3 & 4 & 0 \\
\hline Round 3 & 42 & 0 & 34 & 3 & 3 & 2 & 0 \\
\hline
\end{tabular}

\section{$\underline{\text { Impact Distribution }}$}

Very Low
\begin{tabular}{|c|c|c|c|c|c|c|}
\hline 1 & 2 & 3 & 4 & 5 & 6 & 7 \\
\hline 3 & 4 & 7 & 12 & 10 & 1 & 5 \\
\hline
\end{tabular}

No Response $=1$

Mean Impact Rating $=4.07$

Desirability Distribution

Very Low
\begin{tabular}{|c|c|c|c|c|c|c|}
\hline 1 & 2 & 3 & 4 & 5 & 6 & 7 \\
\hline 3 & 4 & 4 & 11 & 8 & 6 & 6 \\
\hline
\end{tabular}

No Response $=1$

Mean Desirability Rating $=4.40$ 
All comments indicated that this event would occur after the median group response.

Opinions were that training was necessary in general administration but not for three more separate degree programs. Respondents indicated that these skill areas should be a part of general administration degree programs.

Event 92 projected that "There will be a statewide teacher shortage." Time, impact, and desirability data were as follows:

Time Frame Frequency Distribution

\begin{tabular}{|l|c|c|c|c|c|c|c|}
\hline & $\mathrm{N}$ & $\begin{array}{c}1999- \\
2000\end{array}$ & $\begin{array}{c}2001- \\
2010\end{array}$ & $\begin{array}{c}2011- \\
2020\end{array}$ & $\begin{array}{c}\text { After } \\
2020\end{array}$ & Never & NR \\
\hline Round 2 & 43 & 0 & 30 & 7 & 4 & 1 & 1 \\
\hline Round 3 & 42 & 0 & 36 & 2 & 4 & 0 & 0 \\
\hline
\end{tabular}

Impact Distribution

Very Low
\begin{tabular}{|c|c|c|c|c|c|c|}
\hline 1 & 2 & 3 & 4 & 5 & 6 & 7 \\
\hline 0 & 0 & 1 & 3 & 7 & 8 & 23 \\
\hline
\end{tabular}

No Response $=1$

Mean Impact Rating $=6.17$

Desirability Distribution

Very Low
\begin{tabular}{|c|c|c|c|c|c|c|}
\hline 1 & 2 & 3 & 4 & 5 & 6 & 7 \\
\hline 30 & 4 & 3 & 2 & 0 & 0 & 2 \\
\hline
\end{tabular}

No Response $=2$

Mean Desirability Rating $=1.68$ 
One respondent placed this event in the "2011-2020" category and indicated that his/her estimate was based on "enrollment projections and the present over abundance of teachers (especially elementary)." Two other respondents felt this would occur “After 2020." One stated that retirements would coincide with student declines resulting in no shortage. The other also cited declining enrollment, but only say a statewide teacher shortage in certain areas.

Event 93 projected that "Certification requirements will be reduced during a teacher shortage." Time, impact, and desirability data were as follows:

\section{Time Frame Frequency Distribution}

\begin{tabular}{|l|c|c|c|c|c|c|c|}
\hline & $\mathrm{N}$ & $\begin{array}{c}1999- \\
2000\end{array}$ & $\begin{array}{c}2001- \\
2010\end{array}$ & $\begin{array}{c}2011- \\
2020\end{array}$ & $\begin{array}{c}\text { After } \\
2020\end{array}$ & Never & NR \\
\hline Round 2 & 43 & 0 & 25 & 7 & 2 & 5 & 2 \\
\hline Round 3 & 42 & 0 & 35 & 2 & 1 & 3 & 1 \\
\hline
\end{tabular}

\section{Impact Distribution}

Very Low
\begin{tabular}{|c|c|c|c|c|c|c|}
\hline 1 & 2 & 3 & 4 & 5 & 6 & 7 \\
\hline 0 & 1 & 0 & 6 & 8 & 12 & 14 \\
\hline
\end{tabular}

$$
\text { No Response }=2
$$

Mean Impact Rating $=5.76$ 


\section{Desirability Distribution}

Very Low
\begin{tabular}{|c|c|c|c|c|c|c|}
\hline 1 & 2 & 3 & 4 & 5 & 6 & 7 \\
\hline 21 & 6 & 1 & 4 & 3 & 2 & 4 \\
\hline
\end{tabular}

No Response $=2$

Mean Desirability Rating $=2.61$

All respondents indicated this event would occur after the median group response, or would never occur. The reason cited for the delay were reductions in student population which would coincide with a decline in the current overabundance of teachers.

Event 95 projected that "There will be an even greater shortage of administrators than teachers." Time, impact, and desirability data were as follows:

Time Frame Frequency Distribution

\begin{tabular}{|l|c|c|c|c|c|c|c|}
\hline & $\mathrm{N}$ & $\begin{array}{c}1999- \\
2000\end{array}$ & $\begin{array}{c}2001- \\
2010\end{array}$ & $\begin{array}{c}2011- \\
2020\end{array}$ & $\begin{array}{c}\text { After } \\
2020\end{array}$ & Never & NR \\
\hline Round 2 & 43 & 0 & 24 & 4 & 1 & 12 & 2 \\
\hline Round 3 & 42 & 0 & 30 & 2 & 0 & 8 & 2 \\
\hline
\end{tabular}

$\underline{\text { Impact Distribution }}$

Very Low
\begin{tabular}{|c|c|c|c|c|c|c|}
\hline 1 & 2 & 3 & 4 & 5 & 6 & 7 \\
\hline 3 & 0 & 1 & 5 & 6 & 10 & 14 \\
\hline
\end{tabular}

No Response $=4$

Mean Impact Rating $=5.49$ 


\section{Desirability Distribution}

Very Low
\begin{tabular}{|c|c|c|c|c|c|c|}
\hline 1 & 2 & 3 & 4 & 5 & 6 & 7 \\
\hline 22 & 7 & 3 & 3 & 2 & 0 & 1 \\
\hline
\end{tabular}

No Response $=5$

Mean Desirability Rating $=1.95$

All comments represented time frames after the median group response. One respondent stated "The shortage will be in quality. There will always be candidates, just not the ones needed" while another contended "The shortage will be of competent ones." Five panelists who indicated that the event would never occur reasoned that teachers were still motivated by money and that there would always be enough administrators in the pool to select from.

Event 96 projected that "There will be an increase in the number of females entering administrative positions." Time, impact, and desirability data were as follows:

Time Frame Frequency Distribution

\begin{tabular}{|l|c|c|c|c|c|c|c|}
\hline & $\mathrm{N}$ & $\begin{array}{c}1999- \\
2000\end{array}$ & $\begin{array}{c}2001- \\
2010\end{array}$ & $\begin{array}{c}2011- \\
2020\end{array}$ & $\begin{array}{c}\text { After } \\
2020\end{array}$ & Never & NR \\
\hline Round 2 & 43 & 5 & 33 & 3 & 0 & 1 & 1 \\
\hline Round 3 & 42 & 1 & 41 & 0 & 0 & 0 & 0 \\
\hline
\end{tabular}




\section{Impact Distribution}

Very Low
\begin{tabular}{|c|c|c|c|c|c|c|}
\hline 1 & 2 & 3 & 4 & 5 & 6 & 7 \\
\hline 3 & 2 & 3 & 10 & 14 & 5 & 5 \\
\hline
\end{tabular}

No Response $=1$

Mean Impact Rating $=4.55$

Desirability Distribution

Very Low
\begin{tabular}{|c|c|c|c|c|c|c|}
\hline 1 & 2 & 3 & 4 & 5 & 6 & 7 \\
\hline 1 & 0 & 0 & 13 & 3 & 11 & 14 \\
\hline
\end{tabular}

No Response $=1$

Mean Desirability Rating $=5.52$

Only one comment was received for this event which was from the 1999-2000 category.

The respondent indicated that this event will occur over many time frames.

Event 97 projected that "Staffing limits under the state aid formula will increase." Time, impact, and desirability data were as follows:

$\underline{\text { Time Frame Frequency Distribution }}$

\begin{tabular}{|l|c|c|c|c|c|c|c|}
\hline & $\mathrm{N}$ & $\begin{array}{c}1999- \\
2000\end{array}$ & $\begin{array}{c}2001- \\
2010\end{array}$ & $\begin{array}{c}2011- \\
2020\end{array}$ & $\begin{array}{c}\text { After } \\
2020\end{array}$ & Never & NR \\
\hline Round 2 & 43 & 2 & 28 & 5 & 1 & 4 & 3 \\
\hline Round 3 & 42 & 0 & 35 & 3 & 1 & 1 & 2 \\
\hline
\end{tabular}




\section{Impact Distribution}

Very Low
\begin{tabular}{|c|c|c|c|c|c|c|}
\hline 1 & 2 & 3 & 4 & 5 & 6 & 7 \\
\hline 2 & 0 & 1 & 4 & 9 & 10 & 13 \\
\hline
\end{tabular}

No Response $=4$

Mean Impact Rating $=5.56$

Desirability Distribution

Very Low
\begin{tabular}{|c|c|c|c|c|c|c|}
\hline 1 & 2 & 3 & 4 & 5 & 6 & 7 \\
\hline 5 & 3 & 1 & 1 & 3 & 7 & 19 \\
\hline
\end{tabular}

No Response $=4$

Mean Desirability Rating $=5.33$

All respondents indicated that this even will occur in the 2011-2020 time frame.

Respondents indicated that this event "could happen," and that they "would like to see it happen." One stated "I'm not sure the political will can develop that soon."

Event 99 projected that "There will be competency testing for teachers and administrators." Time, impact, and desirability data were as follows:

Time Frame Frequency Distribution

\begin{tabular}{|l|c|c|c|c|c|c|c|}
\hline & $\mathrm{N}$ & $\begin{array}{c}1999- \\
2000\end{array}$ & $\begin{array}{c}2001- \\
2010\end{array}$ & $\begin{array}{c}2011- \\
2020\end{array}$ & $\begin{array}{c}\text { After } \\
2020\end{array}$ & Never & NR \\
\hline Round 2 & 43 & 3 & 22 & 8 & 4 & 6 & 0 \\
\hline Round 3 & 42 & 2 & 33 & 6 & 1 & 1 & 0 \\
\hline
\end{tabular}




\section{Impact Distribution}

Very Low
\begin{tabular}{|c|c|c|c|c|c|c|}
\hline 1 & 2 & 3 & 4 & 5 & 6 & 7 \\
\hline 3 & 0 & 3 & 6 & 7 & 13 & 11 \\
\hline
\end{tabular}

Mean Impact Rating $=5.26$

\section{Desirability Distribution}

Very Low
\begin{tabular}{|c|c|c|c|c|c|c|}
\hline 1 & 2 & 3 & 4 & 5 & 6 & 7 \\
\hline 3 & 3 & 4 & 5 & 3 & 13 & 12 \\
\hline
\end{tabular}

Mean Desirability Rating $=5.07$

One comment was received representing the 1999-2000 time frame which indicated that competency testing for teachers and administrators was already in place in the form of Stanford 9 tests, minimum percentiles for student achievement, and takeovers of county school systems by the West Virginia Department of Education. Those who chose 2011-2020 for occurrence of the event reasoned that the median group response was "too soon" and that it "Takes too long to prepare test and norm it to satisfaction of a variety of stakeholders." Both respondents from the "After 2020" and "Never" categories agreed that professional education employee groups would strongly oppose this event's occurrence.

Event 100 projected that "There will be more emphasis on teaching as a profession." Time, impact, and desirability data were as follows: 
$\underline{\text { Time Frame Frequency Distribution }}$

\begin{tabular}{|l|c|c|c|c|c|c|c|}
\hline & $\mathrm{N}$ & $\begin{array}{c}1999- \\
2000\end{array}$ & $\begin{array}{c}2001- \\
2010\end{array}$ & $\begin{array}{c}2011- \\
2020\end{array}$ & $\begin{array}{c}\text { After } \\
2020\end{array}$ & Never & NR \\
\hline Round 2 & 43 & 2 & 24 & 14 & 0 & 2 & 1 \\
\hline Round 3 & 42 & 0 & 38 & 2 & 0 & 2 & 0 \\
\hline
\end{tabular}

\section{$\underline{\text { Impact Distribution }}$}

Very Low
\begin{tabular}{|c|c|c|c|c|c|c|}
\hline 1 & 2 & 3 & 4 & 5 & 6 & 7 \\
\hline 1 & 0 & 1 & 8 & 14 & 8 & 10 \\
\hline
\end{tabular}

No Response $=1$

Mean Impact Rating $=5.33$

$\underline{\text { Desirability Distribution }}$

\begin{tabular}{|c|c|c|c|c|c|c|}
\hline \multicolumn{6}{|c|}{ Very Low } & Very High \\
\hline 1 & 2 & 3 & 4 & 5 & 6 & 7 \\
\hline 0 & 0 & 0 & 2 & 6 & 12 & 22 \\
\hline
\end{tabular}

One comment was received from the "Never" time frame which stated "Teacher labor unions."

Event 103 projected that "Retirement system restrictions will be relaxed to permit retired teachers to re-enter teaching to offset a teacher shortage." Time, impact, and desirability data were as follows: 
Time Frame Frequency Distribution

\begin{tabular}{|l|c|c|c|c|c|c|c|}
\hline & $\mathrm{N}$ & $\begin{array}{c}1999- \\
2000\end{array}$ & $\begin{array}{c}2001- \\
2010\end{array}$ & $\begin{array}{c}2011- \\
2020\end{array}$ & $\begin{array}{c}\text { After } \\
2020\end{array}$ & Never & NR \\
\hline Round 2 & 43 & 0 & 26 & 11 & 2 & 3 & 1 \\
\hline Round 3 & 42 & 0 & 35 & 4 & 1 & 2 & 0 \\
\hline
\end{tabular}

\section{$\underline{\text { Impact Distribution }}$}

Very Low
\begin{tabular}{|c|c|c|c|c|c|c|}
\hline 1 & 2 & 3 & 4 & 5 & 6 & 7 \\
\hline 1 & 3 & 0 & 13 & 12 & 7 & 4 \\
\hline
\end{tabular}

No Response $=3$

Mean Impact Rating $=4.73$

Desirability Distribution

Very Low
\begin{tabular}{|c|c|c|c|c|c|c|}
\hline 1 & 2 & 3 & 4 & 5 & 6 & 7 \\
\hline 2 & 4 & 5 & 4 & 8 & 11 & 6 \\
\hline
\end{tabular}
No Response $=3$
Mesirability Rating $=4.73$

All responses indicated that this event would occur after the median group response.

Those responding from the 2011-2020 category mentioned that the over supply of teachers would be offset by declining enrollments, thus circumventing a teacher shortage. One respondent indicated that this event would occur "After 2020" because there would be no shortage until that time. The respondent from the "Never" time frame stated that he/she believed "standards will be relaxed instead." 
Event 104 projected that "Teachers who do not have teaching certificates will be recruited from the private sector." Time, impact, and desirability data were as follows:

\section{Time Frame Frequency Distribution}

\begin{tabular}{|l|c|c|c|c|c|c|c|}
\hline & N & $\begin{array}{c}1999- \\
2000\end{array}$ & $\begin{array}{c}2001- \\
2010\end{array}$ & $\begin{array}{c}2011- \\
2020\end{array}$ & $\begin{array}{c}\text { After } \\
2020\end{array}$ & Never & NR \\
\hline Round 2 & 43 & 0 & 22 & 12 & 1 & 7 & 1 \\
\hline Round 3 & 42 & 0 & 33 & 3 & 1 & 5 & 0 \\
\hline
\end{tabular}

\section{Impact Distribution}

Very Low
\begin{tabular}{|c|c|c|c|c|c|c|}
\hline 1 & 2 & 3 & 4 & 5 & 6 & 7 \\
\hline 1 & 1 & 1 & 9 & 9 & 11 & 9 \\
\hline
\end{tabular}

No Response $=2$

Mean Impact Rating $=5.27$

\section{Desirability Distribution}

Very Low
\begin{tabular}{|c|c|c|c|c|c|c|}
\hline 1 & 2 & 3 & 4 & 5 & 6 & 7 \\
\hline 12 & 9 & 3 & 5 & 4 & 5 & 3 \\
\hline
\end{tabular}

No Response $=2$

Mean Desirability Rating $=3.17$

The "2011-2020" and "Never" time frames were the only two from which comments were received. Those responding from 2011-2020 stated that there would not be a teacher shortage until that time which may be offset by declining enrollments. From those who responded that the 
event wound never occur, reasons included that teacher unions and the West Virginia Board of Education would perceive this to weaken the professions and would keep it from occurring. Another stated that "Such a move would require a dramatic change in the School Code relative to the use of noncertified teachers and the school aid formula."

Event 106 projected that "There will be a loss of quality leadership due in part to lack of interest in the principalship by certified and qualified teachers." Time, impact, and desirability data were as follows:

Time Frame Frequency Distribution

\begin{tabular}{|l|c|c|c|c|c|c|c|}
\hline & $\mathrm{N}$ & $\begin{array}{c}1999- \\
2000\end{array}$ & $\begin{array}{c}2001- \\
2010\end{array}$ & $\begin{array}{c}2011- \\
2020\end{array}$ & $\begin{array}{c}\text { After } \\
2020\end{array}$ & Never & NR \\
\hline Round 2 & 43 & 5 & 20 & 2 & 2 & 13 & 1 \\
\hline Round 3 & 42 & 2 & 30 & 0 & 0 & 9 & 1 \\
\hline
\end{tabular}

Impact Distribution

Very Low
\begin{tabular}{|c|c|c|c|c|c|c|}
\hline 1 & 2 & 3 & 4 & 5 & 6 & 7 \\
\hline 1 & 0 & 1 & 3 & 7 & 12 & 16 \\
\hline
\end{tabular}

No Response $=3$

Mean Impact Rating $=5.88$ 


\section{Desirability Distribution}

Very Low
\begin{tabular}{|c|c|c|c|c|c|c|}
\hline 1 & 2 & 3 & 4 & 5 & 6 & 7 \\
\hline 29 & 4 & 1 & 2 & 0 & 1 & 2 \\
\hline
\end{tabular}

No Response $=4$

Mean Desirability Rating $=1.74$

Two respondents indicated that this event would occur in the 1999-2000 time frame and stated that it had already begun. All other comments indicated that the event would never occur. Comments included the thoughts that "Teachers are not oblivious to career ladders" and "Teachers will always be interested in principalships." Higher earnings and the desire on the part of teachers to affect change were offered as reasons for continued interest in principalships.

Event 110 projected that "Child care services will be available at the schools." Time, impact, and desirability data were as follows:

Time Frame Frequency Distribution

\begin{tabular}{|l|c|c|c|c|c|c|c|}
\hline & $\mathrm{N}$ & $\begin{array}{c}1999- \\
2000\end{array}$ & $\begin{array}{c}2001- \\
2010\end{array}$ & $\begin{array}{c}2011- \\
2020\end{array}$ & $\begin{array}{c}\text { After } \\
2020\end{array}$ & Never & NR \\
\hline Round 2 & 43 & 2 & 18 & 15 & 3 & 3 & 1 \\
\hline Round 3 & 42 & 2 & 27 & 10 & 2 & 1 & 0 \\
\hline
\end{tabular}




\section{Impact Distribution}

Very Low
\begin{tabular}{|c|c|c|c|c|c|c|}
\hline 1 & 2 & 3 & 4 & 5 & 6 & 7 \\
\hline 1 & 0 & 3 & 8 & 16 & 5 & 8 \\
\hline
\end{tabular}

No Response $=2$

Mean Impact Rating $=5.07$

Desirability Distribution

Very Low
\begin{tabular}{|c|c|c|c|c|c|c|}
\hline 1 & 2 & 3 & 4 & 5 & 6 & 7 \\
\hline 2 & 3 & 0 & 7 & 12 & 7 & 10 \\
\hline
\end{tabular}

No Response $=2$

Mean Desirability Rating $=5.07$

Both respondents from the 1999-2000 time frame indicated that child care services were already available in several schools. Those commenting from the 2011-2020 time frame indicated that these services would require additional construction or dramatic enrollment declines for adequate space to be available. They also stated that provision of these services would occur in large schools first, but would take "a long time before it reaches to small and rural schools." Competitions from private providers was also mentioned as slowing the event's occurrence. One respondent indicated that these services would never occur and stated that "Child care will continue to be seen as primarily a parental responsibility."

Event 111 projected that "There will be a national insistence on the return to civility in schools." Time, impact, and desirability data were as follows: 
$\underline{\text { Time Frame Frequency Distribution }}$

\begin{tabular}{|l|c|c|c|c|c|c|c|}
\hline & $\mathrm{N}$ & $\begin{array}{c}1999- \\
2000\end{array}$ & $\begin{array}{c}2001- \\
2010\end{array}$ & $\begin{array}{c}2011- \\
2020\end{array}$ & $\begin{array}{c}\text { After } \\
2020\end{array}$ & Never & NR \\
\hline Round 2 & 43 & 6 & 27 & 3 & 1 & 3 & 3 \\
\hline Round 3 & 42 & 3 & 33 & 2 & 1 & 2 & 1 \\
\hline
\end{tabular}

\section{$\underline{\text { Impact Distribution }}$}

Very Low
\begin{tabular}{|c|c|c|c|c|c|c|}
\hline 1 & 2 & 3 & 4 & 5 & 6 & 7 \\
\hline 1 & 1 & 0 & 5 & 12 & 11 & 9 \\
\hline
\end{tabular}

No Response $=4$

Mean Impact Rating $=5.44$

Desirability Distribution

\begin{tabular}{|c|c|c|c|c|c|c|}
\hline \multicolumn{6}{|c|}{ Very Low } & Very Hig \\
\hline 1 & 2 & 3 & 4 & 5 & 6 & 7 \\
\hline 1 & 0 & 0 & 0 & 4 & 12 & 22 \\
\hline
\end{tabular}

Three comments represented the 1999-2000 time frame and indicated that this event had already begun and has "the resolution of both the public and professional associations." One respondent from the "After 2020" category stated that he/she did not agree with, but were willing to change toward the group median. Two others indicated that they did not fully understand the event. One respondent from the "Never" category expressed difficulty with the words "national insistence" and stated "If the nation - citizenry - believes that a President has privacy, they will 
voice concern over civility."

Event 112 projected that "Comprehensive student advisement programs will be developed." Time, impact, and desirability data were as follows:

Time Frame Frequency Distribution

\begin{tabular}{|l|c|c|c|c|c|c|c|}
\hline & $\mathrm{N}$ & $\begin{array}{c}1999- \\
2000\end{array}$ & $\begin{array}{c}2001- \\
2010\end{array}$ & $\begin{array}{c}2011- \\
2020\end{array}$ & $\begin{array}{c}\text { After } \\
2020\end{array}$ & Never & NR \\
\hline Round 2 & 43 & 4 & 26 & 7 & 3 & 1 & 2 \\
\hline Round 3 & 42 & 2 & 38 & 1 & 1 & 0 & 0 \\
\hline
\end{tabular}

\section{Impact Distribution}

Very Low
\begin{tabular}{|c|c|c|c|c|c|c|}
\hline 1 & 2 & 3 & 4 & 5 & 6 & 7 \\
\hline 0 & 1 & 0 & 12 & 14 & 10 & 4 \\
\hline
\end{tabular}

No Response $=2$

Mean Impact Rating $=5.07$

\section{Desirability Distribution}

Very Low
\begin{tabular}{|c|c|c|c|c|c|c|}
\hline 1 & 2 & 3 & 4 & 5 & 6 & 7 \\
\hline 0 & 0 & 1 & 6 & 9 & 18 & 7 \\
\hline
\end{tabular}

No Response $=2$

Mean Desirability Rating $=5.59$

No comments were received for this event.

Event 113 projected that "Cross-county attendance will be routine as attendance will be 
determined by geographic distance, not political boundaries." Time, impact, and desirability data were as follows:

\section{Time Frame Frequency Distribution}

\begin{tabular}{|l|c|c|c|c|c|c|c|}
\hline & $\mathrm{N}$ & $\begin{array}{c}1999- \\
2000\end{array}$ & $\begin{array}{c}2001- \\
2010\end{array}$ & $\begin{array}{c}2011- \\
2020\end{array}$ & $\begin{array}{c}\text { After } \\
2020\end{array}$ & Never & NR \\
\hline Round 2 & 43 & 3 & 24 & 6 & 3 & 6 & 1 \\
\hline Round 3 & 42 & 2 & 35 & 0 & 3 & 2 & 0 \\
\hline
\end{tabular}

\section{Impact Distribution}

Very Low
\begin{tabular}{|c|c|c|c|c|c|c|}
\hline 1 & 2 & 3 & 4 & 5 & 6 & 7 \\
\hline 3 & 0 & 1 & 7 & 11 & 8 & 11 \\
\hline
\end{tabular}

No Response $=2$

Mean Impact Rating $=5.52$

\section{Desirability Distribution}

Very Low
\begin{tabular}{|c|c|c|c|c|c|c|}
\hline 1 & 2 & 3 & 4 & 5 & 6 & 7 \\
\hline 4 & 0 & 3 & 3 & 4 & 13 & 14 \\
\hline
\end{tabular}

No Response $=2$

Mean Desirability Rating $=5.39$

Two respondents from the 1999-2000 time frame indicated that this practice was currently permitted and was established in 1997 under HB2204 of the West Virginia Legislature. One respondent from the "After 2020" category agreed that this is currently occurring, "but will take 
many years to become routine in 55 counties." One respondent viewed this as a local control issue which politically would never be permitted to occur.

Event 115 projected that "Laws governing the discipline of special education students will be relaxed." Time, impact, and desirability data were as follows:

Time Frame Frequency Distribution

\begin{tabular}{|l|c|c|c|c|c|c|c|}
\hline & $\mathrm{N}$ & $\begin{array}{c}1999- \\
2000\end{array}$ & $\begin{array}{c}2001- \\
2010\end{array}$ & $\begin{array}{c}2011- \\
2020\end{array}$ & $\begin{array}{c}\text { After } \\
2020\end{array}$ & Never & NR \\
\hline Round 2 & 43 & 2 & 20 & 4 & 1 & 15 & 1 \\
\hline Round 3 & 42 & 0 & 30 & 2 & 2 & 8 & 0 \\
\hline
\end{tabular}

$\underline{\text { Impact Distribution }}$

Very Low
\begin{tabular}{|c|c|c|c|c|c|c|}
\hline 1 & 2 & 3 & 4 & 5 & 6 & 7 \\
\hline 1 & 3 & 1 & 5 & 10 & 11 & 7 \\
\hline
\end{tabular}

No Response $=5$

Mean Impact Rating $=5.13$

Desirability Distribution

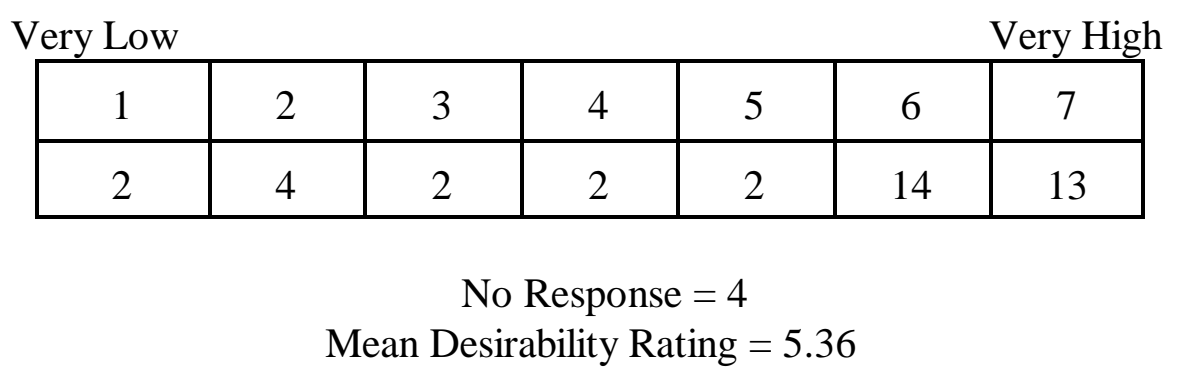

All responses received indicated that this event would occur after the median group 
response. One comment from the 2011-2020 time frame indicated that the "U. S. Supreme Court must undergo significant change first." Another respondent stated that this would be "Politically difficult to achieve." Four comments were made by panelists who felt the event would never occur. Reasons cited included that "As the federal government takes more active role in financing and controlling education the stricter the rights of students become." Others indicated that there were too many powerful special interest groups to allow this to occur.

Event 117 projected that "There will be greater involvement by educators in state and local economic development." Time, impact, and desirability data were as follows:

Time Frame Frequency Distribution

\begin{tabular}{|l|c|c|c|c|c|c|c|}
\hline & $\mathrm{N}$ & $\begin{array}{c}1999- \\
2000\end{array}$ & $\begin{array}{c}2001- \\
2010\end{array}$ & $\begin{array}{c}2011- \\
2020\end{array}$ & $\begin{array}{c}\text { After } \\
2020\end{array}$ & Never & NR \\
\hline Round 2 & 43 & 2 & 19 & 5 & 1 & 14 & 2 \\
\hline Round 3 & 42 & 1 & 34 & 1 & 0 & 5 & 1 \\
\hline
\end{tabular}

$\underline{\text { Impact Distribution }}$

Very Low
\begin{tabular}{|c|c|c|c|c|c|c|}
\hline 1 & 2 & 3 & 4 & 5 & 6 & 7 \\
\hline 3 & 1 & 6 & 8 & 7 & 5 & 8 \\
\hline
\end{tabular}

No Response $=5$

Mean Impact Rating $=4.63$ 


\section{Desirability Distribution}

Very Low
\begin{tabular}{|c|c|c|c|c|c|c|}
\hline 1 & 2 & 3 & 4 & 5 & 6 & 7 \\
\hline 2 & 2 & 0 & 10 & 4 & 6 & 14 \\
\hline
\end{tabular}

No Response $=5$

Mean Desirability Rating $=5.26$

One comment was received which indicated that the event would occur in the 1999-2000 time frame because "SB300 set up partnerships to achieve this." Two other respondents felt the event would never occur because educators are "Not viewed as serious players, unfortunately," and that, although education is always an important issue in economic development, "educators don't seem to exhibit a lot of interest."

Event 118 projected that "Parents will be taught to be educational consumers (life-long learners) and parental involvement will increase." Time, impact, and desirability data were as follows:

Time Frame Frequency Distribution

\begin{tabular}{|l|c|c|c|c|c|c|c|}
\hline & $\mathrm{N}$ & $\begin{array}{c}1999- \\
2000\end{array}$ & $\begin{array}{c}2001- \\
2010\end{array}$ & $\begin{array}{c}2011- \\
2020\end{array}$ & $\begin{array}{c}\text { After } \\
2020\end{array}$ & Never & NR \\
\hline Round 2 & 43 & 2 & 22 & 8 & 3 & 7 & 1 \\
\hline Round 3 & 42 & 1 & 35 & 2 & 1 & 3 & 0 \\
\hline
\end{tabular}




\section{Impact Distribution}

Very Low
\begin{tabular}{|c|c|c|c|c|c|c|}
\hline 1 & 2 & 3 & 4 & 5 & 6 & 7 \\
\hline 0 & 1 & 0 & 5 & 7 & 15 & 14 \\
\hline
\end{tabular}

No Response $=1$

Mean Impact Rating $=5.83$

\section{Desirability Distribution}

Very Low
\begin{tabular}{|c|c|c|c|c|c|c|}
\hline 1 & 2 & 3 & 4 & 5 & 6 & 7 \\
\hline 0 & 0 & 0 & 4 & 1 & 14 & 23 \\
\hline
\end{tabular}

No Response $=1$

Mean Desirability Rating $=6.33$

One panelist indicated that this event would occur in the 1999-2000 time frame because "Parental involvement is a high priority." Two panelists predicted that the event would never occur in any degree greater than what presently exists, and that location would be a major factor in preventing the event's occurrence.

Event 119 projected that "More retirees will become school volunteers." Time, impact, and desirability data were as follows:

Time Frame Frequency Distribution

\begin{tabular}{|l|c|c|c|c|c|c|c|}
\hline & $\mathrm{N}$ & $\begin{array}{c}1999- \\
2000\end{array}$ & $\begin{array}{c}2001- \\
2010\end{array}$ & $\begin{array}{c}2011- \\
2020\end{array}$ & $\begin{array}{c}\text { After } \\
2020\end{array}$ & Never & NR \\
\hline Round 2 & 43 & 3 & 26 & 3 & 2 & 8 & 1 \\
\hline Round 3 & 42 & 1 & 34 & 1 & 1 & 5 & 0 \\
\hline
\end{tabular}




\section{Impact Distribution}

Very Low
\begin{tabular}{|c|c|c|c|c|c|c|}
\hline 1 & 2 & 3 & 4 & 5 & 6 & 7 \\
\hline 0 & 1 & 3 & 11 & 7 & 7 & 11 \\
\hline
\end{tabular}

No Response $=3$

Mean Impact Rating $=5.23$

Desirability Distribution

Very Low
\begin{tabular}{|c|c|c|c|c|c|c|}
\hline 1 & 2 & 3 & 4 & 5 & 6 & 7 \\
\hline 1 & 0 & 2 & 4 & 4 & 12 & 17 \\
\hline
\end{tabular}

No Response $=3$

Mean Desirability Rating $=5.85$

Only one comment was received from the 1999-2000 category indicating that "I'm seeing it happen now." Another respondent who felt the event might occur "After 2020" stated that "Teachers retiring in the next 10 years will either take new jobs or do something else. They will not return for a while." Two panelists said the event would never occur because the number of volunteers will remain constant. One respondent asked "Then why retire?"

Event 123 projected that "There will be a continued out-migration to other states by high school and college graduates, and young families with children. Time, impact, and desirability data were as follows: 
$\underline{\text { Time Frame Frequency Distribution }}$

\begin{tabular}{|l|c|c|c|c|c|c|c|}
\hline & $\mathrm{N}$ & $\begin{array}{c}1999- \\
2000\end{array}$ & $\begin{array}{c}2001- \\
2010\end{array}$ & $\begin{array}{c}2011- \\
2020\end{array}$ & $\begin{array}{c}\text { After } \\
2020\end{array}$ & Never & NR \\
\hline Round 2 & 43 & 15 & 22 & 1 & 1 & 0 & 1 \\
\hline Round 3 & 42 & 10 & 30 & 1 & 0 & 0 & 1 \\
\hline
\end{tabular}

\section{$\underline{\text { Impact Distribution }}$}

Very Low
\begin{tabular}{|c|c|c|c|c|c|c|}
\hline 1 & 2 & 3 & 4 & 5 & 6 & 7 \\
\hline 0 & 0 & 1 & 6 & 8 & 12 & 15 \\
\hline
\end{tabular}

No Response $=1$

Mean Impact Rating $=5.81$

$\underline{\text { Desirability Distribution }}$

\begin{tabular}{l} 
Very Low \\
\begin{tabular}{|c|c|c|c|c|c|c|}
\hline 1 & 2 & 3 & 4 & 5 & 6 & 7 \\
\hline 29 & 6 & 3 & 4 & 0 & 0 & 0 \\
\hline
\end{tabular} \\
Me Response = 1 \\
\hline
\end{tabular}

All but one of the panelists predicted this event would occur in the 1999-2000 time frame with the vast majority noting that this has been happening for many years and will continue to do so. One suggested that "It would be nice if our economy would strengthen enough to reverse this trend." One respondent mentioned that this would occur until the job situation stabilizes and West Virginia begins to experience an increase in technology-based jobs that "can be done here as well as anywhere else." 
Event 124 projected that "Home school students will be allowed to participate on high school athletic teams." Time, impact, and desirability data were as follows:

\section{Time Frame Frequency Distribution}

\begin{tabular}{|l|c|c|c|c|c|c|c|}
\hline & N & $\begin{array}{c}1999- \\
2000\end{array}$ & $\begin{array}{c}2001- \\
2010\end{array}$ & $\begin{array}{c}2011- \\
2020\end{array}$ & $\begin{array}{c}\text { After } \\
2020\end{array}$ & Never & NR \\
\hline Round 2 & 43 & 4 & 25 & 3 & 1 & 8 & 2 \\
\hline Round 3 & 42 & 1 & 34 & 0 & 1 & 5 & 1 \\
\hline
\end{tabular}

\section{Impact Distribution}

Very Low
\begin{tabular}{|c|c|c|c|c|c|c|}
\hline 1 & 2 & 3 & 4 & 5 & 6 & 7 \\
\hline 5 & 6 & 4 & 16 & 3 & 1 & 6 \\
\hline
\end{tabular}

No Response $=2$

Mean Impact Rating $=3.80$

\section{Desirability Distribution}

Very Low
\begin{tabular}{|c|c|c|c|c|c|c|}
\hline 1 & 2 & 3 & 4 & 5 & 6 & 7 \\
\hline 18 & 7 & 2 & 7 & 2 & 2 & 3 \\
\hline
\end{tabular}

No Response $=2$

Mean Desirability Rating $=2.66$

Earlier responses indicated that home school students were already permitted to participate on high school athletic teams. One of the two respondents who indicated the event would never occur stated that "Bias against home schooling runs too deep." 
Event 125 projected that "The number of students being home-schooled will increase."

Time, impact, and desirability data were as follows:

\section{Time Frame Frequency Distribution}

\begin{tabular}{|l|c|c|c|c|c|c|c|}
\hline & $\mathrm{N}$ & $\begin{array}{c}1999- \\
2000\end{array}$ & $\begin{array}{c}2001- \\
2010\end{array}$ & $\begin{array}{c}2011- \\
2020\end{array}$ & $\begin{array}{c}\text { After } \\
2020\end{array}$ & Never & NR \\
\hline Round 2 & 43 & 14 & 22 & 3 & 1 & 2 & 1 \\
\hline Round 3 & 42 & 6 & 34 & 0 & 1 & 1 & 0 \\
\hline
\end{tabular}

\section{Impact Distribution}

Very Low
\begin{tabular}{|c|c|c|c|c|c|c|}
\hline 1 & 2 & 3 & 4 & 5 & 6 & 7 \\
\hline 1 & 3 & 4 & 11 & 9 & 6 & 7 \\
\hline
\end{tabular}

No Response $=2$

Mean Impact Rating $=4.71$

\section{Desirability Distribution}

Very Low
\begin{tabular}{|c|c|c|c|c|c|c|}
\hline 1 & 2 & 3 & 4 & 5 & 6 & 7 \\
\hline 17 & 9 & 3 & 8 & 1 & 1 & 2 \\
\hline
\end{tabular}

No Response $=2$

Mean Desirability Rating $=2.46$

All respondents except one felt this increase had already begun and will not decrease in the foreseeable future. One respondent indicated that the event would never occur because he/she did not believe there would be a further increase beyond the current number of home-schooled 
students.

Event 127 projected that "The standard of living in West Virginia will improve." Time, impact, and desirability data were as follows:

Time Frame Frequency Distribution

\begin{tabular}{|l|c|c|c|c|c|c|c|}
\hline & $\mathrm{N}$ & $\begin{array}{c}1999- \\
2000\end{array}$ & $\begin{array}{c}2001- \\
2010\end{array}$ & $\begin{array}{c}2011- \\
2020\end{array}$ & $\begin{array}{c}\text { After } \\
2020\end{array}$ & Never & NR \\
\hline Round 2 & 43 & 1 & 20 & 13 & 4 & 5 & 0 \\
\hline Round 3 & 42 & 1 & 30 & 10 & 0 & 1 & 0 \\
\hline
\end{tabular}

\section{$\underline{\text { Impact Distribution }}$}

Very Low
\begin{tabular}{|c|c|c|c|c|c|c|}
\hline 1 & 2 & 3 & 4 & 5 & 6 & 7 \\
\hline 0 & 0 & 0 & 5 & 11 & 9 & 18 \\
\hline
\end{tabular}

Mean Impact Rating $=5.93$

Desirability Distribution

Very Low
\begin{tabular}{|c|c|c|c|c|c|c|}
\hline 1 & 2 & 3 & 4 & 5 & 6 & 7 \\
\hline 0 & 0 & 0 & 0 & 1 & 9 & 33 \\
\hline
\end{tabular}

Mean Desirability Rating $=6.74$

One respondent from the "1999-2000" time frame indicated that this event has already begun and will continue over several time frames. All others chose the "2011-2020" category with several predicting an economic plateau, downturn, or recession before any improvement in 
the standard of living. Another responded that West Virginia "must shift from natural resource economy to other types" before the event could occur. One questioned "How can this happen before significant economic growth?"

Event 130 projected that "The NEA (National Education Association) will merge with the AFT (American Federation of Teachers)." Time, impact, and desirability data were as follows:

\section{Time Frame Frequency Distribution}

\begin{tabular}{|l|c|c|c|c|c|c|c|}
\hline & $\mathrm{N}$ & $\begin{array}{c}1999- \\
2000\end{array}$ & $\begin{array}{c}2001- \\
2010\end{array}$ & $\begin{array}{c}2011- \\
2020\end{array}$ & $\begin{array}{c}\text { After } \\
2020\end{array}$ & Never & NR \\
\hline Round 2 & 43 & 0 & 33 & 5 & 2 & 2 & 1 \\
\hline Round 3 & 42 & 0 & 38 & 3 & 0 & 1 & 0 \\
\hline
\end{tabular}

\section{$\underline{\text { Impact Distribution }}$}

Very Low
\begin{tabular}{|c|c|c|c|c|c|c|}
\hline 1 & 2 & 3 & 4 & 5 & 6 & 7 \\
\hline 6 & 3 & 2 & 11 & 9 & 4 & 6 \\
\hline
\end{tabular}

No Response $=2$

Mean Impact Rating $=4.22$

\section{Desirability Distribution}

Very Low
\begin{tabular}{|c|c|c|c|c|c|c|}
\hline 1 & 2 & 3 & 4 & 5 & 6 & 7 \\
\hline 10 & 4 & 2 & 14 & 4 & 3 & 4 \\
\hline
\end{tabular}

No Response $=2$

Mean Desirability Rating $=3.56$

Two comments were received, both from the 2011-2020 time frame. Reasons for the 
delay were the different philosophical bases of the two rival organizations, and that the two groups were still very far apart in their merger negotiations.

Event 132 projected that "The two boards of higher education will be eliminated." Time, impact, and desirability data were as follows:

\section{Time Frame Frequency Distribution}

\begin{tabular}{|l|c|c|c|c|c|c|c|}
\hline & $\mathrm{N}$ & $\begin{array}{c}1999- \\
2000\end{array}$ & $\begin{array}{c}2001- \\
2010\end{array}$ & $\begin{array}{c}2011- \\
2020\end{array}$ & $\begin{array}{c}\text { After } \\
2020\end{array}$ & Never & NR \\
\hline Round 2 & 43 & 3 & 27 & 1 & 2 & 8 & 2 \\
\hline Round 3 & 42 & 0 & 37 & 2 & 1 & 2 & 0 \\
\hline
\end{tabular}

\section{Impact Distribution}

Very Low
\begin{tabular}{|c|c|c|c|c|c|c|}
\hline 1 & 2 & 3 & 4 & 5 & 6 & 7 \\
\hline 2 & 2 & 4 & 14 & 5 & 4 & 9 \\
\hline
\end{tabular}

No Response $=3$

Mean Impact Rating $=4.65$

\section{Desirability Distribution}

Very Low
\begin{tabular}{|c|c|c|c|c|c|c|}
\hline 1 & 2 & 3 & 4 & 5 & 6 & 7 \\
\hline 4 & 2 & 2 & 6 & 10 & 5 & 11 \\
\hline
\end{tabular}

No Response $=3$

Mean Desirability Rating $=4.88$

Two panelists, one from the "2011-2020" and one from the "Never" categories indicated 
that the two boards would not be eliminated but would be restructured or combined. A respondent from the "After 2020" time frame indicated that this event would be delayed due to the magnitude of "overseeing all aspects of all levels of education." Another stated that this event would never occur because "Bureaucracy never dies, it just grows and grows."

\section{1-2010 Time Frame Summary}

Eighty events were projected to occur within this time frame, of which forty-six met the criteria as primary events. Of the forty-six primary events, eighteen were located in the High Impact and High Desirability categories. Those events were numbers 3, 19, 24, 42, 45, 46, 48, 49, 53, 61, 65, 90, 97, 100, 112, 113, 118 and 119. Six other events which met just the High Impact criteria included numbers 6, 14, 31, 34, 37, 71 and 76. Five events including numbers 35, 40, 50, 83, 96 and 117 met only the High Desirability criterion. The High Impact and Low Desirability category included two events, numbers 92 and 93. Four events qualified for inclusion in the Low Desirability category including numbers 63, 72, 124 and 125.

The remaining thirty-four events were included in the secondary category. Fifteen secondary events also met the High Impact and High Desirability categories. Those included events 13, 15, $16,17,23,44,55,62,81,88,99,110,111,115$ and 127 . Five events met only the criteria for inclusion in the High Impact category and included numbers 32, 36, 47, 70 and 104. Event 82 was the only qualifying event in the High Desirability category. Nine events were identified as meeting the criteria for the High Impact and Low Desirability category. Those events were 9, 11, 59, 67, $69,80,95,106$ and 123. Those events which met the criteria for inclusion in the High Impact category were 32, 36, 47, 70 and 104; event 82 was in the High Desirability category; and events 
9, 11, 59, 67, 69, 80, 95, 106 and 123 were in the High Impact and Low Desirability category.

There were no events in the Low Desirability category.

\section{1-2020 Time Frame}

Thirty-eight events were projected to occur within this time frame. The events are again presented in the order in which they appeared on the Round 2 and 3 survey instruments. The number assigned to each event denotes its numerical placement on those survey instruments, and has no other significance.

Event 4 projected that "There will be a change from county to regional school systems." Time, impact, and desirability data were as follows:

\section{Time Frame Frequency Distribution}

\begin{tabular}{|l|c|c|c|c|c|c|c|}
\hline & $\mathrm{N}$ & $\begin{array}{c}1999- \\
2000\end{array}$ & $\begin{array}{c}2001- \\
2010\end{array}$ & $\begin{array}{c}2011- \\
2020\end{array}$ & $\begin{array}{c}\text { After } \\
2020\end{array}$ & Never & NR \\
\hline Round 2 & 43 & 0 & 15 & 16 & 5 & 7 & 0 \\
\hline Round 3 & 42 & 0 & 12 & 22 & 4 & 4 & 0 \\
\hline
\end{tabular}

\section{Impact Distribution}

Very Low
\begin{tabular}{|c|c|c|c|c|c|c|}
\hline 1 & 2 & 3 & 4 & 5 & 6 & 7 \\
\hline 1 & 1 & 1 & 1 & 8 & 12 & 19 \\
\hline
\end{tabular}

Mean Impact Rating $=5.93$ 


\section{Desirability Distribution}

Very Low
\begin{tabular}{|c|c|c|c|c|c|c|}
\hline 1 & 2 & 3 & 4 & 5 & 6 & 7 \\
\hline 4 & 6 & 2 & 7 & 7 & 3 & 14 \\
\hline
\end{tabular}

Mean Desirability Rating $=4.67$

Respondents from the 2001-2010 time frame indicated that this event was "long overdue, and may be a solution to solving the problem of high costs in rural counties." One respondent stated that "technology and transportation issues will cause this to occur sooner." Another noted that " $\mathrm{WV}$ is a poor state that must provide a 'competitive' education system. This issue will surface like the increase in school consolidation. This issue has been discussed in the WV Legislature for about 8 years. Money required for all students to achieve at a high level and public accountability will force this issue." Those responding from the "After 2020" time frame cited loss of local control and county autonomy as reasons delaying regional school systems. Those in the "Never" category agreed that this would relinquish local control and would only occur "if they did away with county government - assessor, sheriff, county commissions, etc."

Event 7 projected that "Services (transportation, food services, maintenance) will be contracted." Time, impact, and desirability data were as follows:

\section{Time Frame Frequency Distribution}

\begin{tabular}{|l|c|c|c|c|c|c|c|}
\hline & $\mathrm{N}$ & $\begin{array}{c}1999- \\
2000\end{array}$ & $\begin{array}{c}2001- \\
2010\end{array}$ & $\begin{array}{c}2011- \\
2020\end{array}$ & $\begin{array}{c}\text { After } \\
2020\end{array}$ & Never & NR \\
\hline Round 2 & 43 & 1 & 18 & 13 & 5 & 5 & 1 \\
\hline Round 3 & 42 & 0 & 14 & 20 & 5 & 3 & 0 \\
\hline
\end{tabular}




\section{Impact Distribution}

Very Low
\begin{tabular}{|c|c|c|c|c|c|c|}
\hline 1 & 2 & 3 & 4 & 5 & 6 & 7 \\
\hline 1 & 2 & 1 & 1 & 15 & 9 & 13 \\
\hline
\end{tabular}

No Response $=1$

Mean Impact Rating $=5.44$

Desirability Distribution

Very Low
\begin{tabular}{|c|c|c|c|c|c|c|}
\hline 1 & 2 & 3 & 4 & 5 & 6 & 7 \\
\hline 3 & 3 & 4 & 4 & 7 & 9 & 12 \\
Mean Desirability Rating $=5.00$
\end{tabular}

Those responding that this event would occur between 2001-2010 gave many reasons for their estimate including budgetary pressures, the number of projected retirements, increasing service personnel salaries, and the use of outsourcing. Panelists in the "After 2020" category indicated that politics would slow down this event because of the value of the service positions and the need to maintain legislative control. Two respondents indicated that the event would never occur because the unions are too strong, the current system is working fine, and "The public will realize that contracting out does not serve the best interest of children."

Event 18 projected that "Every student and teacher will have their own computer equipment and Internet access." Time, impact, and desirability data were as follows: 
Time Frame Frequency Distribution

\begin{tabular}{|l|c|c|c|c|c|c|c|}
\hline & $\mathrm{N}$ & $\begin{array}{c}1999- \\
2000\end{array}$ & $\begin{array}{c}2001- \\
2010\end{array}$ & $\begin{array}{c}2011- \\
2020\end{array}$ & $\begin{array}{c}\text { After } \\
2020\end{array}$ & Never & NR \\
\hline Round 2 & 43 & 0 & 19 & 13 & 7 & 4 & 0 \\
\hline Round 3 & 42 & 0 & 12 & 24 & 4 & 2 & 0 \\
\hline
\end{tabular}

\section{$\underline{\text { Impact Distribution }}$}

Very Low
\begin{tabular}{|c|c|c|c|c|c|c|}
\hline 1 & 2 & 3 & 4 & 5 & 6 & 7 \\
\hline 0 & 0 & 1 & 3 & 9 & 12 & 18 \\
\hline
\end{tabular}

Mean Impact Rating $=6.00$

Desirability Distribution

Very Low
\begin{tabular}{|c|c|c|c|c|c|c|}
\hline 1 & 2 & 3 & 4 & 5 & 6 & 7 \\
\hline 0 & 0 & 0 & 1 & 8 & 11 & 23 \\
\hline
\end{tabular}

Mean Desirability Rating $=6.30$

Many respondents mentioned that the median group response was too soon, particularly based on the progress made over the past 10 years. One panelist commented that "Looking ahead 12 years, I can see computers at every desk in the schools." Another stated that "Through laptops we will be able to send computers home just as we do textbooks now." Those who indicated that this event might be delayed until after 2020 cited cost as an inhibiting factor. "This is particularly true when you consider approximately 325,000 students, 55 systems, and 22,500 teachers or so." One respondent from the "Never" category stated "We have children without the 
basics of life and have always had. I'm not sure the state or the families could provide computers for all children. Although it's a lofty and desirable goal."

Event 20 projected that "Much of the school time of children will be spent in places other than a traditional school building (e.g., home, library, offices, workplaces, specialized labs)." Time, impact, and desirability data were as follows:

\section{Time Frame Frequency Distribution}

\begin{tabular}{|l|c|c|c|c|c|c|c|}
\hline & $\mathrm{N}$ & $\begin{array}{c}1999- \\
2000\end{array}$ & $\begin{array}{c}2001- \\
2010\end{array}$ & $\begin{array}{c}2011- \\
2020\end{array}$ & $\begin{array}{c}\text { After } \\
2020\end{array}$ & Never & NR \\
\hline Round 2 & 43 & 0 & 15 & 13 & 10 & 4 & 1 \\
\hline Round 3 & 42 & 1 & 6 & 26 & 5 & 4 & 0 \\
\hline
\end{tabular}

\section{$\underline{\text { Impact Distribution }}$}

Very Low
\begin{tabular}{|c|c|c|c|c|c|c|}
\hline 1 & 2 & 3 & 4 & 5 & 6 & 7 \\
\hline 0 & 0 & 1 & 5 & 11 & 14 & 11 \\
\hline
\end{tabular}

No Response $=1$

Mean Impact Rating $=5.69$

\section{Desirability Distribution}

Very Low
\begin{tabular}{|c|c|c|c|c|c|c|}
\hline 1 & 2 & 3 & 4 & 5 & 6 & 7 \\
\hline 2 & 2 & 3 & 9 & 11 & 8 & 7 \\
\hline
\end{tabular}

No Response $=1$

Mean Desirability Rating $=4.83$ 
Earlier respondents indicated that "Many students are already participating in off-site work-based learning" and that "The move into the workplace is accelerating." One respondent stated that the event would be delayed until "After 2020" because it would take education 20 years or more to restructure itself away from the use of traditional facilities. Panelists in the "Never" category stated that "We have too much invested and the federal government is addressing \$ for new ones," and that "Many students are already participating in off-site workbased learning."

Event 22 projected that "Increased use of computers and distance learning will reduce the number of teachers needed." Time, impact, and desirability data were as follows:

Time Frame Frequency Distribution

\begin{tabular}{|l|c|c|c|c|c|c|c|}
\hline & $\mathrm{N}$ & $\begin{array}{c}1999- \\
2000\end{array}$ & $\begin{array}{c}2001- \\
2010\end{array}$ & $\begin{array}{c}2011- \\
2020\end{array}$ & $\begin{array}{c}\text { After } \\
2020\end{array}$ & Never & NR \\
\hline Round 2 & 43 & 0 & 12 & 9 & 4 & 17 & 1 \\
\hline Round 3 & 42 & 0 & 5 & 21 & 3 & 13 & 0 \\
\hline
\end{tabular}

\section{$\underline{\text { Impact Distribution }}$}

Very Low
\begin{tabular}{|c|c|c|c|c|c|c|}
\hline 1 & 2 & 3 & 4 & 5 & 6 & 7 \\
\hline 3 & 2 & 2 & 3 & 10 & 7 & 13 \\
\hline
\end{tabular}

$$
\text { No Response }=3
$$

Mean Impact Rating $=5.20$ 


\section{Desirability Distribution}

Very Low
\begin{tabular}{|c|c|c|c|c|c|c|}
\hline 1 & 2 & 3 & 4 & 5 & 6 & 7 \\
\hline 15 & 5 & 7 & 2 & 5 & 1 & 5 \\
\hline
\end{tabular}

$$
\begin{gathered}
\text { No Response }=3 \\
\text { Mean Desirability Rating }=3.00
\end{gathered}
$$

Those responding in the 2001-2010 time frame indicated that they could already see the beginning of this event taking place and that "This will likely coincide with projected high retirements of public school staff in next 5-10 years." Three panelists agreed that this event would be delayed until "After 2020" because of the strength of the public education teachers lobby. One cautioned that "computers, distance learning, etc., are tools rather than teacher replacements per se as was the case with educational TV of several years ago." Those who viewed this event as "Never" occurring felt that, if anything, more teachers would be required as the number of computers increases. "Every time we estimate the savings computers will provide, we find out our requirements increase instead. Maybe new roles for teachers may emerge, but not fewer teachers." Also, "Computers are a great tool, but cannot replace the students' need for personal contact and good role models. An effective balance must be achieved." One mentioned that "There is a natural limit to the usefulness of technology to supplant staff," and that "If anything, it will require retraining of the workforce."

Event 25 projected that "Grades for students will be replaced by comprehensive electronic portfolios that describe the students' capabilities, potential and past accomplishments." Time, impact, and desirability data were as follows: 
Time Frame Frequency Distribution

\begin{tabular}{|l|c|c|c|c|c|c|c|}
\hline & $\mathrm{N}$ & $\begin{array}{c}1999- \\
2000\end{array}$ & $\begin{array}{c}2001- \\
2010\end{array}$ & $\begin{array}{c}2011- \\
2020\end{array}$ & $\begin{array}{c}\text { After } \\
2020\end{array}$ & Never & NR \\
\hline Round 2 & 43 & 0 & 13 & 13 & 7 & 10 & 0 \\
\hline Round 3 & 42 & 0 & 10 & 24 & 5 & 3 & 0 \\
\hline
\end{tabular}

\section{$\underline{\text { Impact Distribution }}$}

Very Low
\begin{tabular}{|c|c|c|c|c|c|c|}
\hline 1 & 2 & 3 & 4 & 5 & 6 & 7 \\
\hline 4 & 2 & 1 & 10 & 10 & 8 & 8 \\
\hline
\end{tabular}

Mean Impact Rating $=4.77$

Desirability Distribution

Very Low
\begin{tabular}{|c|c|c|c|c|c|c|}
\hline 1 & 2 & 3 & 4 & 5 & 6 & 7 \\
\hline 6 & 5 & 3 & 11 & 5 & 5 & 8 \\
\hline
\end{tabular}

Mean Desirability Rating $=4.19$

Four panelists indicated that this event would occur in the 2001-2010 time frame partly because of the requirements of Senate Bill 300. One mentioned that the event would be delayed only in the event that security issues in reporting the data were unresolved. Those who chose the "After 2020" time frame also indicated that security issues may take that long to resolve and envisioned the creation of portfolios, but not the elimination of grades. Respondents who indicated this event would never occur cited the cumbersome nature of creating, processing information, and reading the portfolios. One commented that "The traditional grade is a summary 
of performance. The marketplace will always demand a summary. That's why the media is using grades for schools just as we use them for students."

Event 26 projected that "Hard copy, paper textbooks will be replaced by electronic texts." Time, impact, and desirability data were as follows:

\section{Time Frame Frequency Distribution}

\begin{tabular}{|l|c|c|c|c|c|c|c|}
\hline & $\mathrm{N}$ & $\begin{array}{c}1999- \\
2000\end{array}$ & $\begin{array}{c}2001- \\
2010\end{array}$ & $\begin{array}{c}2011- \\
2020\end{array}$ & $\begin{array}{c}\text { After } \\
2020\end{array}$ & Never & NR \\
\hline Round 2 & 43 & 1 & 4 & 19 & 8 & 11 & 0 \\
\hline Round 3 & 42 & 1 & 3 & 25 & 5 & 8 & 0 \\
\hline
\end{tabular}

\section{Impact Distribution}

Very Low
\begin{tabular}{|c|c|c|c|c|c|c|}
\hline 1 & 2 & 3 & 4 & 5 & 6 & 7 \\
\hline 2 & 2 & 1 & 9 & 16 & 5 & 6 \\
\hline
\end{tabular}

No Response $=2$

Mean Impact Rating $=4.80$

\section{Desirability Distribution}

Very Low
\begin{tabular}{|c|c|c|c|c|c|c|}
\hline 1 & 2 & 3 & 4 & 5 & 6 & 7 \\
\hline 8 & 2 & 4 & 13 & 10 & 1 & 4 \\
\hline
\end{tabular}
Nean Desirability Rating = 3.81

Two respondents indicated that this event would occur in the "2001-2010" time frame, but 
neither offered a specific reason for their estimate other than "This change will come sooner than the median group response." Those panelists who indicated the "After 2020" time frame felt that the amount of money and number of computers necessary for implementation would delay this event. Seven comments were received from the "Never" category, all of which agreed that hard copy texts would remain necessary. Resistance from textbook publishing companies was cited as a reason, along with the idea that the Internet has not reduced the need for hard copy texts in the schools. One respondent commented "I just can't believe that society will decide to rely $100 \%$ on technology, without a safety net." Another stated "Some students will need the printed word on paper to accommodate their learning styles. This is like saying there will be no 'printed Bibles' in WV after 2020 - the state with the oldest population in the nation."

Event 29 projected that "Comprehensive, specialized software that will be customized for each student will be developed and constitute 'the curriculum.'” Time, impact, and desirability data were as follows:

Time Frame Frequency Distribution

\begin{tabular}{|l|c|c|c|c|c|c|c|}
\hline & $\mathrm{N}$ & $\begin{array}{c}1999- \\
2000\end{array}$ & $\begin{array}{c}2001- \\
2010\end{array}$ & $\begin{array}{c}2011- \\
2020\end{array}$ & $\begin{array}{c}\text { After } \\
2020\end{array}$ & Never & NR \\
\hline Round 2 & 43 & 0 & 10 & 12 & 14 & 7 & 0 \\
\hline Round 3 & 42 & 0 & 8 & 20 & 8 & 6 & 0 \\
\hline
\end{tabular}




\section{Impact Distribution}

Very Low
\begin{tabular}{|c|c|c|c|c|c|c|}
\hline 1 & 2 & 3 & 4 & 5 & 6 & 7 \\
\hline 0 & 0 & 2 & 5 & 10 & 15 & 10 \\
\hline
\end{tabular}

No Response $=1$

Mean Impact Rating $=5.62$

\section{Desirability Distribution}

Very Low
\begin{tabular}{|c|c|c|c|c|c|c|}
\hline 1 & 2 & 3 & 4 & 5 & 6 & 7 \\
\hline 3 & 2 & 4 & 6 & 11 & 10 & 6 \\
\hline
\end{tabular}

\section{No Response $=1$}

Mean Desirability Rating $=4.76$

Several panelists indicated that this event would occur in the "2001-2010" time frame because of the rapid changes that are taking place in educational technology and the fact that some specialized software is currently available. Those reporting in the "After 2020" category noted that difficulty, time, and lack of money would slow this event. The respondents who indicated this event would never occur stated that they felt the event was "totally unrealistic" because not all curriculum can be effectively delivered by software, much less "a total individualized education for each student." Another state that "Neither the money nor talent exists to support the kind of innovation for other than the somewhat regimented but cost-effective approach we presently use."

Event 33 projected that "A national testing program will be established." Time, impact, and desirability data were as follows: 
$\underline{\text { Time Frame Frequency Distribution }}$

\begin{tabular}{|l|c|c|c|c|c|c|c|}
\hline & $\mathrm{N}$ & $\begin{array}{c}1999- \\
2000\end{array}$ & $\begin{array}{c}2001- \\
2010\end{array}$ & $\begin{array}{c}2011- \\
2020\end{array}$ & $\begin{array}{c}\text { After } \\
2020\end{array}$ & Never & NR \\
\hline Round 2 & 43 & 1 & 29 & 13 & 2 & 7 & 0 \\
\hline Round 3 & 42 & 0 & 15 & 21 & 0 & 6 & 0 \\
\hline
\end{tabular}

\section{$\underline{\text { Impact Distribution }}$}

Very Low
\begin{tabular}{|c|c|c|c|c|c|c|}
\hline 1 & 2 & 3 & 4 & 5 & 6 & 7 \\
\hline 0 & 2 & 1 & 8 & 8 & 14 & 10 \\
\hline
\end{tabular}

Mean Impact Rating $=5.42$

Desirability Distribution

Very Low
\begin{tabular}{|c|c|c|c|c|c|c|}
\hline 1 & 2 & 3 & 4 & 5 & 6 & 7 \\
\hline 6 & 9 & 5 & 6 & 6 & 4 & 7 \\
\hline
\end{tabular}

Mean Desirability Rating $=3.86$

Respondents from the 2001-2010 time frame mentioned increased interest in the National Assessment of Educational Progress (NAEP) which would serve as the precursor to national testing. Also, the periodic media refocusing on education will heighten public demand for accountability and prompt politicians to require national testing. All other respondents indicated that this event would never occur because states would not cooperate with this federal initiative over the fear of losing local control.

Event 43 projected that "All teacher training programs will take 5 years to complete." 
Time, impact, and desirability data were as follows:

Time Frame Frequency Distribution

\begin{tabular}{|l|c|c|c|c|c|c|c|}
\hline & $\mathrm{N}$ & $\begin{array}{c}1999- \\
2000\end{array}$ & $\begin{array}{c}2001- \\
2010\end{array}$ & $\begin{array}{c}2011- \\
2020\end{array}$ & $\begin{array}{c}\text { After } \\
2020\end{array}$ & Never & NR \\
\hline Round 2 & 43 & 2 & 18 & 13 & 4 & 6 & 0 \\
\hline Round 3 & 42 & 1 & 9 & 28 & 3 & 1 & 0 \\
\hline
\end{tabular}

\section{Impact Distribution}

Very Low
\begin{tabular}{|c|c|c|c|c|c|c|}
\hline 1 & 2 & 3 & 4 & 5 & 6 & 7 \\
\hline 1 & 0 & 4 & 7 & 11 & 13 & 7 \\
\hline
\end{tabular}

Mean Impact Rating $=5.19$

$\underline{\text { Desirability Distribution }}$

Very Low
\begin{tabular}{|c|c|c|c|c|c|c|}
\hline 1 & 2 & 3 & 4 & 5 & 6 & 7 \\
\hline 6 & 3 & 2 & 6 & 11 & 8 & 7 \\
\hline
\end{tabular}

Mean Desirability Rating $=4.51$

Several panelists predicted that this event would occur in the 2001-2010 time frame and noted West Virginia University as having a 5-year teacher education program. Two respondents indicated that the event would occur in the "After 2020" and "Never" time frames because the added expense of such a program would not be appealing to students or their parents. One panelist commented " A critical teacher shortage will be here sooner - training programs will likely 
become shorter...Besides, going to five years' college expense will turn candidates away."

Event 51 projected that " A foreign language will be offered in all elementary schools."

Time, impact, and desirability data were as follows:

Time Frame Frequency Distribution

\begin{tabular}{|l|c|c|c|c|c|c|c|}
\hline & $\mathrm{N}$ & $\begin{array}{c}1999- \\
2000\end{array}$ & $\begin{array}{c}2001- \\
2010\end{array}$ & $\begin{array}{c}2011- \\
2020\end{array}$ & $\begin{array}{c}\text { After } \\
2020\end{array}$ & Never & NR \\
\hline Round 2 & 43 & 1 & 16 & 19 & 2 & 4 & 1 \\
\hline Round 3 & 42 & 1 & 12 & 26 & 0 & 3 & 0 \\
\hline
\end{tabular}

\section{Impact Distribution}

Very Low
\begin{tabular}{|c|c|c|c|c|c|c|}
\hline 1 & 2 & 3 & 4 & 5 & 6 & 7 \\
\hline 0 & 0 & 4 & 12 & 12 & 9 & 3 \\
\hline
\end{tabular}

No Response $=3$

Mean Impact Rating $=4.88$

\section{Desirability Distribution}

Very Low
\begin{tabular}{|c|c|c|c|c|c|c|}
\hline 1 & 2 & 3 & 4 & 5 & 6 & 7 \\
\hline 1 & 2 & 3 & 7 & 5 & 11 & 11 \\
\hline
\end{tabular}

No Response $=3$

Mean Desirability Rating $=5.25$

The majority of those who commented indicated that this event would occur earlier than the median group response. The public will demand these programs as "The world continues to 
grow smaller and the need becomes more evident daily." Another indicated that the "State will begin to listen to research which indicates it should be taught at this level." One respondent stated that the event would never occur because of "resource limits."

Event 54 projected that "Public confidence and support in public education will be restored." Time, impact, and desirability data were as follows:

\section{Time Frame Frequency Distribution}

\begin{tabular}{|l|c|c|c|c|c|c|c|}
\hline & $\mathrm{N}$ & $\begin{array}{c}1999- \\
2000\end{array}$ & $\begin{array}{c}2001- \\
2010\end{array}$ & $\begin{array}{c}2011- \\
2020\end{array}$ & $\begin{array}{c}\text { After } \\
2020\end{array}$ & Never & NR \\
\hline Round 2 & 43 & 2 & 16 & 14 & 2 & 7 & 2 \\
\hline Round 3 & 42 & 1 & 13 & 19 & 1 & 7 & 1 \\
\hline
\end{tabular}

\section{$\underline{\text { Impact Distribution }}$}

Very Low
\begin{tabular}{|c|c|c|c|c|c|c|}
\hline 1 & 2 & 3 & 4 & 5 & 6 & 70 \\
\hline 0 & 1 & 1 & 3 & 7 & 4 & 24 \\
\hline
\end{tabular}

No Response $=3$

Mean Impact Rating $=6.10$

\section{Desirability Distribution}

Very Low
\begin{tabular}{|c|c|c|c|c|c|c|}
\hline 1 & 2 & 3 & 4 & 5 & 6 & 7 \\
\hline 0 & 1 & 0 & 3 & 0 & 4 & 32 \\
\hline
\end{tabular}

No Response $=3$

Mean Desirability Rating $=6.55$ 
The comment received from the "1999-2000" time frame indicated that public confidence and support in public education will depend on accountability. Similar comments came from the "2001-2010" group, one of which suggested that "we are becoming more accountable for our students' education - performance of schools and higher standards will increase public confidence in our schools." If public confidence is not restored before the median group response, one panelist mentioned that public education "will not exist as we know it" and that vouchers would likely emerge. Those in the "Never" category viewed the situation as only getting worse. One commented that "By its very nature, public education is, and will be, controversial: the "most public of public institutions." Another questioned "What event will occur to cause this change?" Event 56 projected that "A system of merit pay will be enacted." Time, impact, and desirability data were as follows:

$\underline{\text { Time Frame Frequency Distribution }}$

\begin{tabular}{|l|c|c|c|c|c|c|c|}
\hline & $\mathrm{N}$ & $\begin{array}{c}1999- \\
2000\end{array}$ & $\begin{array}{c}2001- \\
2010\end{array}$ & $\begin{array}{c}2011- \\
2020\end{array}$ & $\begin{array}{c}\text { After } \\
2020\end{array}$ & Never & NR \\
\hline Round 2 & 43 & 0 & 14 & 9 & 6 & 14 & 0 \\
\hline Round 3 & 42 & 0 & 8 & 22 & 3 & 9 & 0 \\
\hline
\end{tabular}

\section{$\underline{\text { Impact Distribution }}$}

Very Low
\begin{tabular}{|c|c|c|c|c|c|c|}
\hline 1 & 2 & 3 & 4 & 5 & 6 & 7 \\
\hline 0 & 5 & 2 & 4 & 11 & 9 & 12 \\
\hline
\end{tabular}

Mean Impact Rating $=5.23$ 


\section{Desirability Distribution}

Very Low
\begin{tabular}{|c|c|c|c|c|c|c|}
\hline 1 & 2 & 3 & 4 & 5 & 6 & 7 \\
\hline 8 & 3 & 2 & 4 & 5 & 6 & 15 \\
\hline
\end{tabular}

Mean Desirability Rating $=4.70$

Responses from the "2001-2010" category were that West Virginia would "Join this national trend" in which "Some states are already examining standardized test scores and rewarding teachers for 'value added' test score gains of individual students." Respondents who represented the "Never" time frame indicated that the political strength of the teachers associations would prevent this from happening. One panelist noted that "Merit pay schemes are not the answer. Comments and information from other states show that merit pay is a waste of money." Others commented that merit pay might be appropriate for schools as rewards for student success, "But individual merit pay unlikely in the politics of poverty environment of WV."

Event 57 projected that "The funding of education will become the responsibility of the state with little or no local discretionary funding." Time, impact, and desirability data were as follows:

Time Frame Frequency Distribution

\begin{tabular}{|l|c|c|c|c|c|c|c|}
\hline & $\mathrm{N}$ & $\begin{array}{c}1999- \\
2000\end{array}$ & $\begin{array}{c}2001- \\
2010\end{array}$ & $\begin{array}{c}2011- \\
2020\end{array}$ & $\begin{array}{c}\text { After } \\
2020\end{array}$ & Never & NR \\
\hline Round 2 & 43 & 1 & 14 & 9 & 5 & 13 & 1 \\
\hline Round 3 & 42 & 0 & 8 & 26 & 2 & 6 & 1 \\
\hline
\end{tabular}




\section{Impact Distribution}

Very Low
\begin{tabular}{|c|c|c|c|c|c|c|}
\hline 1 & 2 & 3 & 4 & 5 & 6 & 7 \\
\hline 1 & 0 & 0 & 9 & 5 & 13 & 13 \\
\hline
\end{tabular}

No Response $=2$

Mean Impact Rating $=5.63$

Desirability Distribution

Very Low
\begin{tabular}{|c|c|c|c|c|c|c|}
\hline 1 & 2 & 3 & 4 & 5 & 6 & 7 \\
\hline 12 & 9 & 4 & 5 & 4 & 2 & 5 \\
\hline
\end{tabular}

No Response $=2$

Mean Desirability Rating $=3.15$

Respondents who estimated this event in the 2001-2010 time frame stated that this might occur "by court actions." One noted that "According to many superintendents, there is already very little discretion." The need to maintain local control and the potential increases in state and personal income taxes necessary to fund this would result in the event not occurring. One respondent noted that this event was "Inconsistent with school finance theory."

Event 58 projected that "A statewide school excess levy will be approved.” Time, impact, and desirability data were as follows: 
$\underline{\text { Time Frame Frequency Distribution }}$

\begin{tabular}{|l|c|c|c|c|c|c|c|}
\hline & $\mathrm{N}$ & $\begin{array}{c}1999- \\
2000\end{array}$ & $\begin{array}{c}2001- \\
2010\end{array}$ & $\begin{array}{c}2011- \\
2020\end{array}$ & $\begin{array}{c}\text { After } \\
2020\end{array}$ & Never & NR \\
\hline Round 2 & 43 & 1 & 20 & 6 & 1 & 15 & 0 \\
\hline Round 3 & 42 & 0 & 12 & 17 & 0 & 13 & 0 \\
\hline
\end{tabular}

\section{$\underline{\text { Impact Distribution }}$}

Very Low
\begin{tabular}{|c|c|c|c|c|c|c|}
\hline 1 & 2 & 3 & 4 & 5 & 6 & 7 \\
\hline 1 & 0 & 1 & 5 & 5 & 13 & 17 \\
\hline
\end{tabular}

No Response $=1$

Mean Impact Rating $=5.86$

Desirability Distribution

Very Low
\begin{tabular}{|c|c|c|c|c|c|c|}
\hline 1 & 2 & 3 & 4 & 5 & 6 & 7 \\
\hline 4 & 4 & 0 & 2 & 3 & 8 & 21 \\
\hline
\end{tabular}
Nean Desponse $=1$
Desirability Rating $=5.48$

Those in the 2001-2020 time frame indicated that this event will occur because of court actions and the desire of the public to have equity in funding. It was also noted that "Public support for improved results will lead to willingness to pass a levy." Another stated that the "Recht litigation resolution will require it." Respondents who said this would never happen cited increases in state and personal income taxes and the loss of local control as reasons for nonoccurrence. 
Event 60 projected that "The percentage of local bond passages will improve." Time, impact, and desirability data were as follows:

\section{Time Frame Frequency Distribution}

\begin{tabular}{|l|c|c|c|c|c|c|c|}
\hline & N & $\begin{array}{c}1999- \\
2000\end{array}$ & $\begin{array}{c}2001- \\
2010\end{array}$ & $\begin{array}{c}2011- \\
2020\end{array}$ & $\begin{array}{c}\text { After } \\
2020\end{array}$ & Never & NR \\
\hline Round 2 & 43 & 2 & 17 & 9 & 1 & 15 & 0 \\
\hline Round 3 & 42 & 0 & 11 & 23 & 0 & 8 & 0 \\
\hline
\end{tabular}

\section{$\underline{\text { Impact Distribution }}$}

Very Low
\begin{tabular}{|c|c|c|c|c|c|c|}
\hline 1 & 2 & 3 & 4 & 5 & 6 & 7 \\
\hline 1 & 0 & 1 & 4 & 8 & 12 & 17 \\
\hline
\end{tabular}

Mean Impact Rating $=5.84$

Desirability Distribution

Very Low
\begin{tabular}{|c|c|c|c|c|c|c|}
\hline 1 & 2 & 3 & 4 & 5 & 6 & 7 \\
\hline 3 & 0 & 3 & 2 & 3 & 12 & 20 \\
\hline
\end{tabular}

Mean Desirability Rating $=5.74$

Respondents to this event were divided on the issues of public confidence and support. Those in the 2001-2010 time frame stated that public confidence and support were currently at high levels whereas those who indicated the event would never occur felt it was low. One respondent simply stated "Dream on!" 
Event 66 projected that "A national/universal health care program will be established." Time, impact, and desirability data were as follows:

\section{Time Frame Frequency Distribution}

\begin{tabular}{|l|c|c|c|c|c|c|c|}
\hline & $\mathrm{N}$ & $\begin{array}{c}1999- \\
2000\end{array}$ & $\begin{array}{c}2001- \\
2010\end{array}$ & $\begin{array}{c}2011- \\
2020\end{array}$ & $\begin{array}{c}\text { After } \\
2020\end{array}$ & Never & NR \\
\hline Round 2 & 43 & 0 & 12 & 11 & 4 & 15 & 1 \\
\hline Round 3 & 42 & 0 & 7 & 25 & 2 & 7 & 1 \\
\hline
\end{tabular}

\section{Impact Distribution}

Very Low
\begin{tabular}{|c|c|c|c|c|c|c|}
\hline 1 & 2 & 3 & 4 & 5 & 6 & 7 \\
\hline 1 & 2 & 2 & 6 & 6 & 10 & 13 \\
\hline
\end{tabular}

No Response $=3$

Mean Impact Rating $=5.40$

\section{Desirability Distribution}

Very Low
\begin{tabular}{|c|c|c|c|c|c|c|}
\hline 1 & 2 & 3 & 4 & 5 & 6 & 7 \\
\hline 4 & 2 & 1 & 7 & 3 & 9 & 14 \\
\hline
\end{tabular}

No Response $=3$

Mean Desirability Rating $=5.15$

Five respondents commented about this event occurring in the 2001-2010 time frame, one of whom indicated that "Both parties recognize the need for this is some form." Another noted that there "Will likely be a national system in 2001-2010, which West Virginia will happily join 
because of inadequate funds to support its own health care demands." Those who felt the event would never occur simply states that "Just not hopeful" and "Not politically correct."

Event 68 projected that "Funding for education will be diverted to meet the health care needs of the elderly." Time, impact, and desirability data were as follows:

\section{Time Frame Frequency Distribution}

\begin{tabular}{|l|c|c|c|c|c|c|c|}
\hline & $\mathrm{N}$ & $\begin{array}{c}1999- \\
2000\end{array}$ & $\begin{array}{c}2001- \\
2010\end{array}$ & $\begin{array}{c}2011- \\
2020\end{array}$ & $\begin{array}{c}\text { After } \\
2020\end{array}$ & Never & NR \\
\hline Round 2 & 43 & 1 & 8 & 14 & 6 & 13 & 1 \\
\hline Round 3 & 42 & 0 & 4 & 27 & 2 & 8 & 1 \\
\hline
\end{tabular}

Impact Distribution

Very Low
\begin{tabular}{|c|c|c|c|c|c|c|}
\hline 1 & 2 & 3 & 4 & 5 & 6 & 7 \\
\hline 0 & 1 & 0 & 6 & 9 & 8 & 16 \\
\hline
\end{tabular}

No Response $=3$

Mean Impact Rating $=5.78$

\section{Desirability Distribution}

Very Low
\begin{tabular}{|c|c|c|c|c|c|c|}
\hline 1 & 2 & 3 & 4 & 5 & 6 & 7 \\
\hline 20 & 13 & 2 & 4 & 0 & 0 & 1 \\
\hline
\end{tabular}
Mean Desirability Rating $=1.88$

Earlier respondents indicated that they are already seeing signs of this through the current 
political emphasis and budgetary considerations concerning social security. One stated that the baby boomers, as they grow older, will have more need for health care and less need for education. Other respondents from the "Never" category stressed that the general public's value of education would prevent this from occurring. One panelist who did not specify a time frame stated that the "Percentage of state budget for education may decline and health care for seniors may increase. That does not necessarily equate to diverting funds."

Event 74 projected that "Private schools may lead to a resurrection of boarding schools for the children of busy, upwardly mobile, two income families." Time, impact, and desirability data were as follows:

Time Frame Frequency Distribution

\begin{tabular}{|l|c|c|c|c|c|c|c|}
\hline & $\mathrm{N}$ & $\begin{array}{c}1999- \\
2000\end{array}$ & $\begin{array}{c}2001- \\
2010\end{array}$ & $\begin{array}{c}2011- \\
2020\end{array}$ & $\begin{array}{c}\text { After } \\
2020\end{array}$ & Never & NR \\
\hline Round 2 & 43 & 0 & 7 & 13 & 7 & 15 & 1 \\
\hline Round 3 & 42 & 0 & 4 & 22 & 3 & 13 & 0 \\
\hline
\end{tabular}

Impact Distribution

Very Low
\begin{tabular}{|c|c|c|c|c|c|c|}
\hline 1 & 2 & 3 & 4 & 5 & 6 & 7 \\
\hline 4 & 4 & 5 & 9 & 7 & 5 & 4 \\
\hline
\end{tabular}

No Response $=5$

Mean Impact Rating $=4.11$ 


\section{Desirability Distribution}

Very Low
\begin{tabular}{|c|c|c|c|c|c|c|}
\hline 1 & 2 & 3 & 4 & 5 & 6 & 7 \\
\hline 11 & 9 & 7 & 7 & 3 & 0 & 1 \\
\hline
\end{tabular}

\section{No Response $=5$}

Mean Desirability Rating $=2.63$

Only one comment was received from the 2001-2010 time frame - "Economic climate is right for 2005 and beyond." All other comments represented the "Never" category. Limited wealth and the need to have children in contact with their family unit were the major reasons cited. One responded "Nationally, this may occur...WV probably will not be a player..." Event 84 projected that "Every school will be air conditioned." Time, impact, and desirability data were as follows:

Time Frame Frequency Distribution

\begin{tabular}{|l|c|c|c|c|c|c|c|}
\hline & $\mathrm{N}$ & $\begin{array}{c}1999- \\
2000\end{array}$ & $\begin{array}{c}2001- \\
2010\end{array}$ & $\begin{array}{c}2011- \\
2020\end{array}$ & $\begin{array}{c}\text { After } \\
2020\end{array}$ & Never & NR \\
\hline Round 2 & 43 & 0 & 16 & 19 & 4 & 2 & 2 \\
\hline Round 3 & 42 & 0 & 11 & 29 & 1 & 1 & 0 \\
\hline
\end{tabular}

\section{Impact Distribution}

Very Low
\begin{tabular}{|c|c|c|c|c|c|c|}
\hline 1 & 2 & 3 & 4 & 5 & 6 & 7 \\
\hline 1 & 1 & 4 & 7 & 9 & 7 & 11 \\
\hline
\end{tabular}

No Response $=3$

Mean Impact Rating $=5.18$ 


\section{Desirability Distribution}

Very Low
\begin{tabular}{|c|c|c|c|c|c|c|}
\hline 1 & 2 & 3 & 4 & 5 & 6 & 7 \\
\hline 2 & 1 & 2 & 0 & 4 & 10 & 21 \\
\hline
\end{tabular}

No Response $=3$

Mean Desirability Rating $=5.93$

Seven comments were received from the 2001-2010 time frame. All agreed that this was "needed," "fairly easy to do," and would be necessary "As schools move to year-round use by the community." "This will be part of all new construction as older buildings are replaced," and "School consolidations and federal money for facilities will make this possible." The one respondent from the "Never" category expressed a concern over the use of the word "every."

Event 86 projected that "There will be a phone on every teacher's desk." Time, impact, and desirability data were as follows:

Time Frame Frequency Distribution

\begin{tabular}{|l|c|c|c|c|c|c|c|}
\hline & $\mathrm{N}$ & $\begin{array}{c}1999- \\
2000\end{array}$ & $\begin{array}{c}2001- \\
2010\end{array}$ & $\begin{array}{c}2011- \\
2020\end{array}$ & $\begin{array}{c}\text { After } \\
2020\end{array}$ & Never & NR \\
\hline Round 2 & 43 & 0 & 13 & 17 & 3 & 10 & 0 \\
\hline Round 3 & 42 & 0 & 8 & 26 & 1 & 7 & 0 \\
\hline
\end{tabular}




\section{Impact Distribution}

Very Low
\begin{tabular}{|c|c|c|c|c|c|c|}
\hline 1 & 2 & 3 & 4 & 5 & 6 & 7 \\
\hline 3 & 4 & 7 & 8 & 11 & 4 & 6 \\
\hline
\end{tabular}

Mean Impact Rating $=4.30$

\section{Desirability Distribution}

Very Low
\begin{tabular}{|c|c|c|c|c|c|c|}
\hline 1 & 2 & 3 & 4 & 5 & 6 & 7 \\
\hline 4 & 4 & 3 & 6 & 5 & 6 & 15 \\
\hline
\end{tabular}

Mean Desirability Rating $=4.91$

Safety of students and employees was cited as the main reason for this event occurring in the "2001-2010" time frame. Other comments included "After 2020 there won't be phones," and "Phones will be part of computer. Teachers will have computers, and the phone capability that comes with it." Those responding that this event would never occur stated that phones would be seen as a disruption, but teachers would all have computers with E-mail capabilities, or perhaps a cellular phone.

Event 87 projected that "Personnel laws will be revised so that they are more favorable to employers." Time, impact, and desirability data were as follows: 
$\underline{\text { Time Frame Frequency Distribution }}$

\begin{tabular}{|l|c|c|c|c|c|c|c|}
\hline & $\mathrm{N}$ & $\begin{array}{c}1999- \\
2000\end{array}$ & $\begin{array}{c}2001- \\
2010\end{array}$ & $\begin{array}{c}2011- \\
2020\end{array}$ & $\begin{array}{c}\text { After } \\
2020\end{array}$ & Never & NR \\
\hline Round 2 & 43 & 1 & 14 & 11 & 4 & 13 & 0 \\
\hline Round 3 & 42 & 1 & 9 & 19 & 4 & 9 & 0 \\
\hline
\end{tabular}

\section{$\underline{\text { Impact Distribution }}$}

Very Low
\begin{tabular}{|c|c|c|c|c|c|c|}
\hline 1 & 2 & 3 & 4 & 5 & 6 & 7 \\
\hline 2 & 1 & 2 & 4 & 7 & 8 & 17 \\
\hline
\end{tabular}

No Response $=2$

Mean Impact Rating $=5.56$

Desirability Distribution

Very Low
\begin{tabular}{|c|c|c|c|c|c|c|}
\hline 1 & 2 & 3 & 4 & 5 & 6 & 7 \\
\hline 5 & 6 & 2 & 3 & 5 & 4 & 16 \\
\hline
\end{tabular}

No Response $=2$

Mean Desirability Rating $=4.78$

Responses from the 2001-2010 category indicated that this event must occur if West

Virginia is going to have a competitive educational system. Others stated that "Societal problems will require more employer control," and "the coming personnel shortage will hasten this phenomenon." All those who commented that the event would not occur noted resistance from the teachers' associations and their lobbyists.

Event 94 projected that "Alternatives to traditional college teacher education programs 
will be established to certify school teachers." Time, impact, and desirability data were as follows:

\section{Time Frame Frequency Distribution}

\begin{tabular}{|l|c|c|c|c|c|c|c|}
\hline & $\mathrm{N}$ & $\begin{array}{c}1999- \\
2000\end{array}$ & $\begin{array}{c}2001- \\
2010\end{array}$ & $\begin{array}{c}2011- \\
2020\end{array}$ & $\begin{array}{c}\text { After } \\
2020\end{array}$ & Never & NR \\
\hline Round 2 & 43 & 3 & 15 & 13 & 2 & 8 & 2 \\
\hline Round 3 & 42 & 2 & 11 & 23 & 3 & 1 & 2 \\
\hline
\end{tabular}

\section{$\underline{\text { Impact Distribution }}$}

Very Low
\begin{tabular}{|c|c|c|c|c|c|c|}
\hline 1 & 2 & 3 & 4 & 5 & 6 & 7 \\
\hline 1 & 2 & 1 & 8 & 10 & 6 & 12 \\
\hline
\end{tabular}

No Response $=3$

Mean Impact Rating $=5.25$

\section{Desirability Distribution}

Very Low
\begin{tabular}{|c|c|c|c|c|c|c|}
\hline 1 & 2 & 3 & 4 & 5 & 6 & 7 \\
\hline 7 & 7 & 0 & 6 & 7 & 8 & 5 \\
\hline
\end{tabular}

No Response $=3$

Mean Desirability Rating $=4.08$

The two respondents from the "1999-2000" time frame and stated that this already exists in the form of "experimental' or 'alternative' programs." All other responses were from the "2001-2010" time frame and indicated that this is already occurring in other states and that a 
teacher shortage may cause it to occur in West Virginia as well. Other reasons included the "possibility of charter schools who will 'think and act' differently," and "Competition among higher education institutions, and new alternatives, will be connected to distance learning advancements."

Event 98 projected that "Teachers will become much more specialized and focus on narrow content areas." Time, impact, and desirability data were as follows:

Time Frame Frequency Distribution

\begin{tabular}{|l|c|c|c|c|c|c|c|}
\hline & $\mathrm{N}$ & $\begin{array}{c}1999- \\
2000\end{array}$ & $\begin{array}{c}2001- \\
2010\end{array}$ & $\begin{array}{c}2011- \\
2020\end{array}$ & $\begin{array}{c}\text { After } \\
2020\end{array}$ & Never & NR \\
\hline Round 2 & 43 & 0 & 14 & 12 & 3 & 12 & 2 \\
\hline Round 3 & 42 & 0 & 10 & 24 & 3 & 5 & 0 \\
\hline
\end{tabular}

\section{Impact Distribution}

Very Low
\begin{tabular}{|c|c|c|c|c|c|c|}
\hline 1 & 2 & 3 & 4 & 5 & 6 & 7 \\
\hline 2 & 2 & 2 & 12 & 7 & 5 & 9 \\
\hline
\end{tabular}

No Response $=4$

Mean Impact Rating $=4.82$

Desirability Distribution

Very Low
\begin{tabular}{|c|c|c|c|c|c|c|}
\hline 1 & 2 & 3 & 4 & 5 & 6 & 7 \\
\hline 8 & 4 & 2 & 7 & 9 & 3 & 6 \\
\hline
\end{tabular}

No Response $=4$

Mean Desirability Rating $=3.97$ 
In the 2001-2010 time frame increased teacher specialization was viewed as "a natural outgrowth with larger, consolidated schools" and as most prevalent in the upper grades. Those who indicated that this would never occur reasoned that, because of the upcoming teacher shortage, "we will have fewer teachers available, they will be more generalized" and that "When you are generalized, you have greater chance for jobs." It was also noted was that there is already a movement toward fewer certification areas.

Event 102 projected that "There will be a nurse in every school." Time, impact, and desirability data were as follows:

Time Frame Frequency Distribution

\begin{tabular}{|l|c|c|c|c|c|c|c|}
\hline & $\mathrm{N}$ & $\begin{array}{c}1999- \\
2000\end{array}$ & $\begin{array}{c}2001- \\
2010\end{array}$ & $\begin{array}{c}2011- \\
2020\end{array}$ & $\begin{array}{c}\text { After } \\
2020\end{array}$ & Never & NR \\
\hline Round 2 & 43 & 0 & 13 & 10 & 3 & 16 & 1 \\
\hline Round 3 & 42 & 0 & 8 & 20 & 2 & 12 & 0 \\
\hline
\end{tabular}

\section{Impact Distribution}

Very Low
\begin{tabular}{|c|c|c|c|c|c|c|}
\hline 1 & 2 & 3 & 4 & 5 & 6 & 7 \\
\hline 1 & 1 & 2 & 6 & 11 & 10 & 8 \\
\hline
\end{tabular}

No Response $=4$

Mean Impact Rating $=5.23$ 


\section{Desirability Distribution}

Very Low
\begin{tabular}{|c|c|c|c|c|c|c|}
\hline 1 & 2 & 3 & 4 & 5 & 6 & 7 \\
\hline 2 & 2 & 3 & 6 & 4 & 8 & 14 \\
\hline
\end{tabular}

No Response $=4$

Mean Desirability Rating $=5.26$

Respondents in the 2001-2010 category indicated that the increasing number of lawsuits, medications and various conditions and student labels will bring this event about. One panelist stated that the "Public will demand it sooner given peaking interest in child health issues." Nine commented that the event would never occur primarily because of cost and staffing limitations. One participant stated "If we can't afford teachers, how can we afford nurses? We need them, but we must give up something to get them." Another reason cited was that this could happen if the number of schools were reduced through consolidation and were large enough to justify the event.

Event 107 projected that "Schools will become year round in most or all counties." Time, impact, and desirability data were as follows:

$\underline{\text { Time Frame Frequency Distribution }}$

\begin{tabular}{|l|c|c|c|c|c|c|c|}
\hline & $\mathrm{N}$ & $\begin{array}{c}1999- \\
2000\end{array}$ & $\begin{array}{c}2001- \\
2010\end{array}$ & $\begin{array}{c}2011- \\
2020\end{array}$ & $\begin{array}{c}\text { After } \\
2020\end{array}$ & Never & NR \\
\hline Round 2 & 43 & 0 & 6 & 24 & 6 & 7 & 0 \\
\hline Round 3 & 42 & 0 & 4 & 29 & 3 & 6 & 0 \\
\hline
\end{tabular}




\section{Impact Distribution}

Very Low
\begin{tabular}{|c|c|c|c|c|c|c|}
\hline 1 & 2 & 3 & 4 & 5 & 6 & 7 \\
\hline 2 & 0 & 0 & 3 & 14 & 11 & 13 \\
\hline
\end{tabular}

Mean Impact Rating $=5.60$

\section{Desirability Distribution}

Very Low
\begin{tabular}{|c|c|c|c|c|c|c|}
\hline 1 & 2 & 3 & 4 & 5 & 6 & 7 \\
\hline 3 & 3 & 0 & 7 & 11 & 8 & 11 \\
\hline
\end{tabular}

Mean Desirability Rating $=5.05$

Those responding in the 2001-2010 category offered no reason for their estimate other than "Public will support this." Panelists from the "Never" category indicated that "Parents want status quo" and that "Year round is needed where surplus of students exists. Not West Virginia, ever. This will not occur in all schools."

Event 108 projected that "The length of the school year will be extended." Time, impact, and desirability data were as follows:

Time Frame Frequency Distribution

\begin{tabular}{|l|c|c|c|c|c|c|c|}
\hline & $\mathrm{N}$ & $\begin{array}{c}1999- \\
2000\end{array}$ & $\begin{array}{c}2001- \\
2010\end{array}$ & $\begin{array}{c}2011- \\
2020\end{array}$ & $\begin{array}{c}\text { After } \\
2020\end{array}$ & Never & NR \\
\hline Round 2 & 43 & 0 & 19 & 19 & 4 & 1 & 0 \\
\hline Round 3 & 42 & 0 & 16 & 24 & 1 & 1 & 0 \\
\hline
\end{tabular}




\section{Impact Distribution}

Very Low
\begin{tabular}{|c|c|c|c|c|c|c|}
\hline 1 & 2 & 3 & 4 & 5 & 6 & 7 \\
\hline 2 & 0 & 0 & 8 & 11 & 13 & 9 \\
\hline
\end{tabular}

Mean Impact Rating $=5.35$

\section{Desirability Distribution}

Very Low
\begin{tabular}{|c|c|c|c|c|c|c|}
\hline 1 & 2 & 3 & 4 & 5 & 6 & 7 \\
\hline 1 & 0 & 1 & 8 & 10 & 12 & 11 \\
\hline
\end{tabular}

Mean Desirability Rating $=5.47$

All comments came from the 2001-2010 time frame. Reasons included the need for accountability to the public "To enhance education quality and achievement" and that year round schools are gaining popularity. One panelist mentioned that the school year might be extended to provide for more staff development.

Event 109 projected that "The length of the school day will be extended." Time, impact, and desirability data were as follows:

Time Frame Frequency Distribution

\begin{tabular}{|l|c|c|c|c|c|c|c|}
\hline & $\mathrm{N}$ & $\begin{array}{c}1999- \\
2000\end{array}$ & $\begin{array}{c}2001- \\
2010\end{array}$ & $\begin{array}{c}2011- \\
2020\end{array}$ & $\begin{array}{c}\text { After } \\
2020\end{array}$ & Never & NR \\
\hline Round 2 & 43 & 0 & 19 & 11 & 2 & 11 & 0 \\
\hline Round 3 & 42 & 0 & 13 & 23 & 0 & 6 & 0 \\
\hline
\end{tabular}




\section{Impact Distribution}

Very Low
\begin{tabular}{|c|c|c|c|c|c|c|}
\hline 1 & 2 & 3 & 4 & 5 & 6 & 7 \\
\hline 1 & 0 & 7 & 4 & 11 & 10 & 9 \\
\hline
\end{tabular}

No Response $=1$

Mean Impact Rating $=5.14$

Desirability Distribution

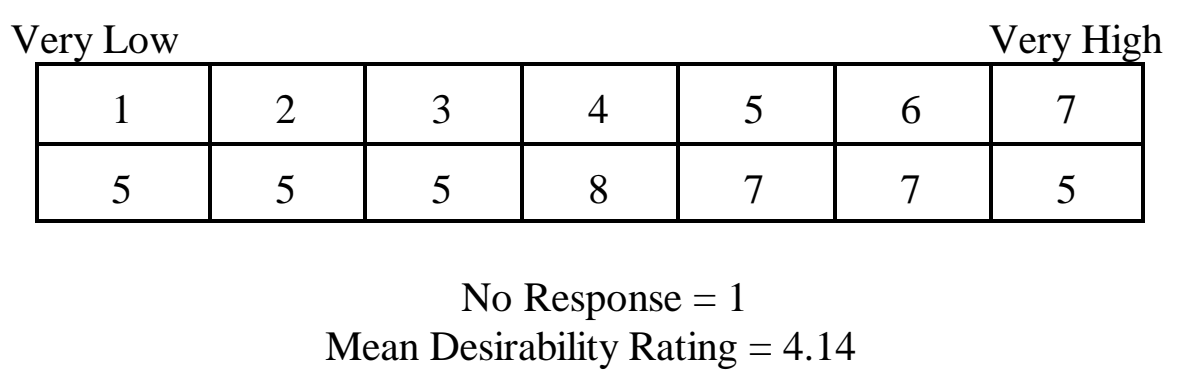

This event was viewed by those in the 2001-2010 category as a needed reform "as we demand more of students." One respondent indicated that the school day might be lengthened "By no more than 20 minutes and could be subsequently shortened." Those who stated that this would never occur indicated that this was not supported by research and, with fewer schools, would cause longer transportation times. Several respondents indicated that he/she could agree with a longer school year, but not a longer school day.

Event 114 projected that "Compulsory school attendance laws will be redefined to allow students to stay at home with computers and use distance learning." Time, impact, and desirability data were as follows: 
$\underline{\text { Time Frame Frequency Distribution }}$

\begin{tabular}{|l|c|c|c|c|c|c|c|}
\hline & $\mathrm{N}$ & $\begin{array}{c}1999- \\
2000\end{array}$ & $\begin{array}{c}2001- \\
2010\end{array}$ & $\begin{array}{c}2011- \\
2020\end{array}$ & $\begin{array}{c}\text { After } \\
2020\end{array}$ & Never & NR \\
\hline Round 2 & 43 & 0 & 14 & 15 & 6 & 7 & 1 \\
\hline Round 3 & 42 & 0 & 11 & 21 & 5 & 5 & 0 \\
\hline
\end{tabular}

\section{$\underline{\text { Impact Distribution }}$}

Very Low
\begin{tabular}{|c|c|c|c|c|c|c|}
\hline 1 & 2 & 3 & 4 & 5 & 6 & 7 \\
\hline 0 & 1 & 1 & 10 & 5 & 10 & 13 \\
\hline
\end{tabular}

No Response $=3$

Mean Impact Rating $=5.53$

Desirability Distribution

\begin{tabular}{l} 
Very Low \\
\begin{tabular}{|c|c|c|c|c|c|c|}
\hline 1 & 2 & 3 & 4 & 5 & 6 & 7 \\
\hline 5 & 8 & 3 & 11 & 3 & 5 & 5 \\
\hline
\end{tabular} \\
Mean Desponse $=3$ \\
\hline
\end{tabular}

Respondents from the 2001-2010 category noted that this event has already begun through students who are home bound due to illness or court order. One stated that "It won't replace schools, but will serve as an alternative for some." Those responding in the "After 2020" category said that this would be expensive, would place students in unsupervised situations, and would not be accepted well by the public. Lack of funding was a primary reason expressed by those in the "Never" time frame. Respondents also noted that this event would eliminate the 
social aspects of school, including extra curricular activities, that students need. One commented that "If this happens, the organizational structure/institution of education will be lost! Educational institutionalization has taken hundreds of years to develop."

Event 116 projected that "Programs will be designed for special needs students rather than being placed in a normal classroom situation (inclusion)." Time, impact, and desirability data were as follows:

Time Frame Frequency Distribution

\begin{tabular}{|l|c|c|c|c|c|c|c|}
\hline & $\mathrm{N}$ & $\begin{array}{c}1999- \\
2000\end{array}$ & $\begin{array}{c}2001- \\
2010\end{array}$ & $\begin{array}{c}2011- \\
2020\end{array}$ & $\begin{array}{c}\text { After } \\
2020\end{array}$ & Never & NR \\
\hline Round 2 & 43 & 0 & 15 & 6 & 8 & 12 & 2 \\
\hline Round 3 & 42 & 0 & 10 & 19 & 4 & 8 & 1 \\
\hline
\end{tabular}

Impact Distribution

Very Low
\begin{tabular}{|c|c|c|c|c|c|c|}
\hline 1 & 2 & 3 & 4 & 5 & 6 & 7 \\
\hline 1 & 2 & 0 & 8 & 7 & 10 & 9 \\
\hline
\end{tabular}

No Response $=6$

Mean Impact Rating $=5.27$

Desirability Distribution

Very Low
\begin{tabular}{|c|c|c|c|c|c|c|}
\hline 1 & 2 & 3 & 4 & 5 & 6 & 7 \\
\hline 5 & 2 & 1 & 9 & 6 & 7 & 7 \\
\hline
\end{tabular}

No Response $=6$

Mean Desirability Rating $=4.57$ 
For respondents in the 2001-2010 time frame, this event has already begun to happen as “We already are seeing 'resegregation' as a result of inappropriate inclusion." Others commented that "Student performance expectations will force this," and that "Some administrators have gone too far in their interpretation of inclusion. Inclusion has been so controversial and its results have not shown clear evidence of positive academic results. I believe it will be interpreted on a more individual basis so that only children who can really benefit from inclusion will be placed there." Those who felt this event would never occur indicated that the law was clear about the necessity of this program. Others noted that inclusion would increase in popularity because it is cheaper and "politically correct."

Event 121 projected that “All students will have IEPs (Individualized Education Plans).” Time, impact, and desirability data were as follows:

Time Frame Frequency Distribution

\begin{tabular}{|l|c|c|c|c|c|c|c|}
\hline & $\mathrm{N}$ & $\begin{array}{c}1999- \\
2000\end{array}$ & $\begin{array}{c}2001- \\
2010\end{array}$ & $\begin{array}{c}2011- \\
2020\end{array}$ & $\begin{array}{c}\text { After } \\
2020\end{array}$ & Never & NR \\
\hline Round 2 & 43 & 1 & 15 & 15 & 4 & 7 & 1 \\
\hline Round 3 & 42 & 0 & 8 & 29 & 2 & 3 & 0 \\
\hline
\end{tabular}

\section{$\underline{\text { Impact Distribution }}$}

Very Low
\begin{tabular}{|c|c|c|c|c|c|c|}
\hline 1 & 2 & 3 & 4 & 5 & 6 & 7 \\
\hline 3 & 0 & 2 & 4 & 6 & 14 & 10 \\
\hline
\end{tabular}

No Response $=4$

Mean Impact Rating $=5.36$ 


\section{Desirability Distribution}

Very Low
\begin{tabular}{|c|c|c|c|c|c|c|}
\hline 1 & 2 & 3 & 4 & 5 & 6 & 7 \\
\hline 5 & 2 & 2 & 7 & 5 & 6 & 12 \\
\hline
\end{tabular}

No Response $=4$

Mean Desirability Rating $=4.82$

Respondents from the 2001-2010 category noted that this event will become reality because of the "current analysis of SAT-9 performance" and the current "5-year plans" which "are already IEPs by another name." Those in the "After 2020" and "Never" categories both agreed that this would be a time consuming and costly process which would be lobbied against.

Event 122 projected that "The statewide college-going rate will exceed 66\%." Time, impact, and desirability data were as follows:

Time Frame Frequency Distribution

\begin{tabular}{|l|c|c|c|c|c|c|c|}
\hline & $\mathrm{N}$ & $\begin{array}{c}1999- \\
2000\end{array}$ & $\begin{array}{c}2001- \\
2010\end{array}$ & $\begin{array}{c}2011- \\
2020\end{array}$ & $\begin{array}{c}\text { After } \\
2020\end{array}$ & Never & NR \\
\hline Round 2 & 43 & 0 & 10 & 18 & 5 & 9 & 1 \\
\hline Round 3 & 42 & 0 & 5 & 31 & 0 & 6 & 0 \\
\hline
\end{tabular}

\section{$\underline{\text { Impact Distribution }}$}

Very Low
\begin{tabular}{|c|c|c|c|c|c|c|}
\hline 1 & 2 & 3 & 4 & 5 & 6 & 7 \\
\hline 2 & 0 & 1 & 3 & 6 & 14 & 13 \\
\hline
\end{tabular}

No Response $=4$

Mean Impact Rating $=5.69$ 


\section{Desirability Distribution}

Very Low
\begin{tabular}{|c|c|c|c|c|c|c|}
\hline 1 & 2 & 3 & 4 & 5 & 6 & 7 \\
\hline 2 & 0 & 1 & 5 & 5 & 8 & 19 \\
\hline
\end{tabular}

No Response $=3$

Mean Desirability Rating $=5.78$

Earlier responses in the "2001-2010" time frame indicated that this was a state-wide

priority and that the present "college going rate is 64 percent now" and would increase before 2011. Those who responded from the "Never" category stated that West Virginia does not have the jobs for college graduates and "The culture will never value higher education to that extent." One mentioned “We've never even hit $40 \%$ for graduating seniors - I can't imagine $66 \%$ of all students!!”

Event 126 projected that "West Virginia will experience significant economic growth." Time, impact, and desirability data were as follows:

Time Frame Frequency Distribution

\begin{tabular}{|l|c|c|c|c|c|c|c|}
\hline & $\mathrm{N}$ & $\begin{array}{c}1999- \\
2000\end{array}$ & $\begin{array}{c}2001- \\
2010\end{array}$ & $\begin{array}{c}2011- \\
2020\end{array}$ & $\begin{array}{c}\text { After } \\
2020\end{array}$ & Never & NR \\
\hline Round 2 & 43 & 1 & 15 & 13 & 4 & 8 & 2 \\
\hline Round 3 & 42 & 3 & 9 & 26 & 1 & 3 & 0 \\
\hline
\end{tabular}




\section{Impact Distribution}

Very Low
\begin{tabular}{|c|c|c|c|c|c|c|}
\hline 1 & 2 & 3 & 4 & 5 & 6 & 7 \\
\hline 0 & 0 & 0 & 2 & 8 & 15 & 16 \\
\hline
\end{tabular}

No Response $=2$

Mean Impact Rating $=6.10$

Desirability Distribution

Very Low
\begin{tabular}{|c|c|c|c|c|c|c|}
\hline 1 & 2 & 3 & 4 & 5 & 6 & 7 \\
\hline 0 & 0 & 0 & 1 & 0 & 7 & 32 \\
Mean Desirability Rating $=6.75$
\end{tabular}

Two respondents from the "1999-2000" time frame and indicated that the event would continue over subsequent time frames. "2001-2010" respondents mentioned that "Our education system is an important link in attaining this goal," and "Optimistic this will happen as schools improve." Those in the "Never" category questioned what would cause future economic growth by asking "Based on what? The same factors governing economic growth will continue to exist." Another noted that "There is nothing special to make this happen to WV. It is not necessarily a bad thing if this does not occur."

Event 128 projected that "West Virginia will become an information-based economy." Time, impact, and desirability data were as follows: 
$\underline{\text { Time Frame Frequency Distribution }}$

\begin{tabular}{|l|c|c|c|c|c|c|c|}
\hline & $\mathrm{N}$ & $\begin{array}{c}1999- \\
2000\end{array}$ & $\begin{array}{c}2001- \\
2010\end{array}$ & $\begin{array}{c}2011- \\
2020\end{array}$ & $\begin{array}{c}\text { After } \\
2020\end{array}$ & Never & NR \\
\hline Round 2 & 43 & 1 & 11 & 9 & 11 & 8 & 3 \\
\hline Round 3 & 42 & 1 & 8 & 24 & 5 & 4 & 0 \\
\hline
\end{tabular}

$\underline{\text { Impact Distribution }}$

Very Low
\begin{tabular}{|c|c|c|c|c|c|c|}
\hline 1 & 2 & 3 & 4 & 5 & 6 & 7 \\
\hline 0 & 0 & 1 & 2 & 9 & 12 & 15 \\
\hline
\end{tabular}

No Response $=4$

Mean Impact Rating $=5.97$

Desirability Distribution

Very Low
\begin{tabular}{|c|c|c|c|c|c|c|}
\hline 1 & 2 & 3 & 4 & 5 & 6 & 7 \\
\hline 2 & 0 & 3 & 4 & 7 & 6 & 17 \\
\hline
\end{tabular}

No Response $=4$

Mean Desirability Rating $=5.56$

Responses from the "1999-2000" and "2001-2010" time frames indicated that this has already begun in West Virginia. Others from the "After 2020" category stated that the median group response was "too soon given current basis and how much change would be required." Another commented that "the future economy will be based on service provision." One respondent who indicated the event would never occur stated "It will become more information based but I don't see an entire change in our rural way of life." 
Event 129 projected that "The stock market will plummet to a record low, affecting state investments." Time, impact, and desirability data were as follows:

\section{Time Frame Frequency Distribution}

\begin{tabular}{|l|c|c|c|c|c|c|c|}
\hline & N & $\begin{array}{c}1999- \\
2000\end{array}$ & $\begin{array}{c}2001- \\
2010\end{array}$ & $\begin{array}{c}2011- \\
2020\end{array}$ & $\begin{array}{c}\text { After } \\
2020\end{array}$ & Never & NR \\
\hline Round 2 & 43 & 6 & 10 & 2 & 4 & 15 & 6 \\
\hline Round 3 & 42 & 3 & 10 & 10 & 1 & 14 & 4 \\
\hline
\end{tabular}

\section{$\underline{\text { Impact Distribution }}$}

Very Low
\begin{tabular}{|c|c|c|c|c|c|c|}
\hline 1 & 2 & 3 & 4 & 5 & 6 & 7 \\
\hline 1 & 0 & 1 & 2 & 5 & 7 & 20 \\
\hline
\end{tabular}

No Response $=7$

Mean Impact Rating $=6.08$

\section{Desirability Distribution}

Very Low
\begin{tabular}{|c|c|c|c|c|c|c|}
\hline 1 & 2 & 3 & 4 & 5 & 6 & 7 \\
\hline 31 & 3 & 0 & 1 & 1 & 0 & 0 \\
\hline
\end{tabular}

No Response $=7$

Mean Desirability Rating $=1.28$

Those in both the 1999-2000 and 2001-2010 time frames predicted that a decline was already evident because of layoff announcements, cutbacks reported in the newspapers, and the deteriorating economic situation in oversees markets. Later respondents from "After 2020" and 
"Never" mentioned that there were too many checks and balances for the stock market to "plummet." The group agreed that downturns and recessions are likely, with "peaks and valleys, with (an) upward trend."

Event 131 projected that "The WV Department of Education will be downsized." Time, impact, and desirability data were as follows:

\section{Time Frame Frequency Distribution}

\begin{tabular}{|l|c|c|c|c|c|c|c|}
\hline & $\mathrm{N}$ & $\begin{array}{c}1999- \\
2000\end{array}$ & $\begin{array}{c}2001- \\
2010\end{array}$ & $\begin{array}{c}2011- \\
2020\end{array}$ & $\begin{array}{c}\text { After } \\
2020\end{array}$ & Never & NR \\
\hline Round 2 & 43 & 4 & 17 & 4 & 0 & 17 & 1 \\
\hline Round 3 & 42 & 3 & 11 & 17 & 0 & 11 & 0 \\
\hline
\end{tabular}

\section{$\underline{\text { Impact Distribution }}$}

Very Low
\begin{tabular}{|c|c|c|c|c|c|c|}
\hline 1 & 2 & 3 & 4 & 5 & 6 & 7 \\
\hline 4 & 1 & 7 & 11 & 7 & 2 & 7 \\
\hline
\end{tabular}

No Response $=4$

Mean Impact Rating $=4.28$

Desirability Distribution

Very Low
\begin{tabular}{|c|c|c|c|c|c|c|}
\hline 1 & 2 & 3 & 4 & 5 & 6 & 7 \\
\hline 11 & 8 & 3 & 6 & 7 & 2 & 3 \\
\hline
\end{tabular}

No Response $=3$

Mean Desirability Rating $=3.20$ 
Respondents from both the 1999-2000 and 2001-2010 time frames indicated that this event has already begun and will likely continue. "Over the next 10 years the state department will continue to downsize - as a result, county school systems will become more responsible for a quality education." Another reason cited was "This will occur as schools receive more technical assistance from 'other sources' and the West Virginia Department of Education becomes more regulatory with public accountability." Others who responded that this event would never occur all made observations about the nature of bureaucracies - "It's not the nature of a bureaucracy to get smaller!," "Departments of Education are never downsized," and "Bureaucracy never dies, it just grows and grows."

Event 133 projected that "A self-standing community college system will be created." Time, impact, and desirability data were as follows:

Time Frame Frequency Distribution

\begin{tabular}{|l|c|c|c|c|c|c|c|}
\hline & $\mathrm{N}$ & $\begin{array}{c}1999- \\
2000\end{array}$ & $\begin{array}{c}2001- \\
2010\end{array}$ & $\begin{array}{c}2011- \\
2020\end{array}$ & $\begin{array}{c}\text { After } \\
2020\end{array}$ & Never & NR \\
\hline Round 2 & 43 & 0 & 18 & 9 & 2 & 13 & 1 \\
\hline Round 3 & 42 & 1 & 13 & 21 & 1 & 6 & 0 \\
\hline
\end{tabular}

\section{Impact Distribution}

Very Low
\begin{tabular}{|c|c|c|c|c|c|c|}
\hline 1 & 2 & 3 & 4 & 5 & 6 & 7 \\
\hline 3 & 2 & 0 & 9 & 10 & 11 & 6 \\
\hline
\end{tabular}

No Response $=2$

Mean Impact Rating $=4.90$ 


\section{Desirability Distribution}

Very Low
\begin{tabular}{|c|c|c|c|c|c|c|}
\hline 1 & 2 & 3 & 4 & 5 & 6 & 7 \\
\hline 10 & 2 & 0 & 9 & 6 & 5 & 9 \\
\hline
\end{tabular}

No Response $=2$

Mean Desirability Rating $=4.22$

One respondent from the 1999-2000 category stated that a self-standing college system "was already created." Several respondents from the 2001-2010 category stated that this issue was close to occurring as "Money from the legislative budget has already been allocated to study this possibility." Another indicated that "Informed discussions with Board of Directors and legislators indicate interest is currently very high." Those who felt this event would never occur cited competition to maintain control and budgets, and "university jealousies" as reasons. One indicated that "This has been attempted unsuccessfully for 15 years!"

Event 134 projected that "Secondary vocational programs and community colleges will be under one administrative unit." Time, impact, and desirability data were as follows:

Time Frame Frequency Distribution

\begin{tabular}{|l|c|c|c|c|c|c|c|}
\hline & $\mathrm{N}$ & $\begin{array}{c}1999- \\
2000\end{array}$ & $\begin{array}{c}2001- \\
2010\end{array}$ & $\begin{array}{c}2011- \\
2020\end{array}$ & $\begin{array}{c}\text { After } \\
2020\end{array}$ & Never & NR \\
\hline Round 2 & 43 & 0 & 14 & 10 & 2 & 15 & 2 \\
\hline Round 3 & 42 & 1 & 7 & 23 & 0 & 10 & 1 \\
\hline
\end{tabular}




\section{Impact Distribution}

Very Low
\begin{tabular}{|c|c|c|c|c|c|c|}
\hline 1 & 2 & 3 & 4 & 5 & 6 & 7 \\
\hline 4 & 2 & 1 & 8 & 8 & 7 & 7 \\
\hline
\end{tabular}

No Response $=6$

Mean Impact Rating $=4.70$

Desirability Distribution

Very Low
\begin{tabular}{|c|c|c|c|c|c|c|}
\hline 1 & 2 & 3 & 4 & 5 & 6 & 7 \\
\hline 9 & 4 & 3 & 10 & 2 & 2 & 8 \\
Mean Desirability Rating $=3.79$
\end{tabular}

Earlier respondents from both the "1999-2000" and "2001-2010" categories indicated that "We have that in quasi format now," and that "This is already beginning to be bandied about and promises to be a lively topic of discussion in the upcoming legislative session." The panelists who indicated that the event would never occur said that "public education will fight to continue control vocational education dollars as well." Another mentioned "This would be awful. Too awful to even entertain."

\section{1-2020 Time Frame Summary}

Of the thirty-eight events in this time frame, none qualified for inclusion as "primary" events. Thirteen events were in the High Impact and High Desirability categories including numbers 7, 18, 54, 58, 60, 66, 84, 102, 107, 108, 122, 126 and 128. Numbers 4, 20, 29, 33, 43, 
56, 57, 87, 94, 109, 114, 116 and 121 were High Impact events while number 51 was a High

Desirability event. Three events met the criteria as High Impact and Low Desirability including numbers 22, 68 and 129. Only one event, number 74, qualified as a Low Desirability event.

\section{After 2020 Time Frame}

Five events were projected to occur "After 2020." These events are presented as they appeared on the Round 2 and 3 survey instruments. The number assigned to each event denotes its numerical placement on those survey instruments.

Event 8 projected that "County school boards will be eliminated." Time, impact, and desirability data were as follows:

Time Frame Frequency Distribution

\begin{tabular}{|l|c|c|c|c|c|c|c|}
\hline & $\mathrm{N}$ & $\begin{array}{c}1999- \\
2000\end{array}$ & $\begin{array}{c}2001- \\
2010\end{array}$ & $\begin{array}{c}2011- \\
2020\end{array}$ & $\begin{array}{c}\text { After } \\
2020\end{array}$ & Never & NR \\
\hline Round 2 & 43 & 0 & 4 & 12 & 7 & 20 & 0 \\
\hline Round 3 & 42 & 0 & 3 & 8 & 16 & 15 & 0 \\
\hline
\end{tabular}

Impact Distribution

Very Low
\begin{tabular}{|c|c|c|c|c|c|c|}
\hline 1 & 2 & 3 & 4 & 5 & 6 & 7 \\
\hline 3 & 0 & 0 & 3 & 3 & 10 & 22 \\
\hline
\end{tabular}

No Response $=2$

Mean Impact Rating $=5.95$ 


\section{Desirability Distribution}

Very Low
\begin{tabular}{|c|c|c|c|c|c|c|}
\hline 1 & 2 & 3 & 4 & 5 & 6 & 7 \\
\hline 13 & 6 & 3 & 7 & 2 & 4 & 7 \\
\hline
\end{tabular}

No Response $=1$

Mean Desirability Rating $=3.45$

Respondents from the 2001-2010 and 2011-2020 time frames indicated that school boards would be eliminated "as decisions will be made on a regional basis." Another reasoned that "political pressures and education reform will extinguish county boards sooner. It won't require a constitutional amendment, just legislation." All other comments came from the "Never" category. Resistance to relinquishing local control, and the idea that county boards of education are "too much a part of the school culture" were offered as reasons. One mentioned "This would only occur if they did away with county government - assessor, sheriff, county commissions, etc."

Event 28 projected that "WV will fall behind neighboring states in use of educational technology." Time, impact, and desirability data were as follows:

Time Frame Frequency Distribution

\begin{tabular}{|l|c|c|c|c|c|c|c|}
\hline & $\mathrm{N}$ & $\begin{array}{c}1999- \\
2000\end{array}$ & $\begin{array}{c}2001- \\
2010\end{array}$ & $\begin{array}{c}2011- \\
2020\end{array}$ & $\begin{array}{c}\text { After } \\
2020\end{array}$ & Never & NR \\
\hline Round 2 & 43 & 1 & 15 & 5 & 1 & 21 & 0 \\
\hline Round 3 & 42 & 1 & 11 & 6 & 12 & 12 & 0 \\
\hline
\end{tabular}




\section{Impact Distribution}

Very Low
\begin{tabular}{|c|c|c|c|c|c|c|}
\hline 1 & 2 & 3 & 4 & 5 & 6 & 7 \\
\hline 3 & 0 & 0 & 9 & 10 & 9 & 8 \\
\hline
\end{tabular}

No Response $=4$

Mean Impact Rating $=5.10$

Desirability Distribution

Very Low
\begin{tabular}{|c|c|c|c|c|c|c|}
\hline 1 & 2 & 3 & 4 & 5 & 6 & 7 \\
\hline 31 & 6 & 0 & 0 & 1 & 1 & 1 \\
Mean Desirability Rating $=1.53$
\end{tabular}

One respondent from the 1999-2000 time frame commented that "We will catch up with other states, not fall behind." Others in the 2001-2010 category stated that "Our lead in technology is greatly exaggerated" and that "'Given the rapid evolution of technology and the related escalating costs it will be difficult to keep up with wealthier states over the next decade." Comments on funding indicated that "The political arena of funding is too uncertain to believe this funding will be stable for 20 years. Other priorities will be established." Another stated that “Downswing in foreign countries' economies will affect U. S. economy, especially a poor state like West Virginia, causing the state to have less money for education. Money will go for health care instead." Those in the 2011-2020 time frame also had funding concerns. Comments from this group included "West Virginia is the poorest of surrounding states and this will cause other states to be able to spend more," and "Once the surrounding states get dedicated to the use of 
educational technology, they have more resources to advance the training, etc." Several responded that West Virginia would never fall behind in technology, citing the commitment of the state board of education, the legislature and the Governor.

Event 30 projected that "Teacher avatars (computerized embodiments of another person a sports figure, celebrity, etc.) will allow students to choose and interact with who they are most comfortable learning from." Time, impact, and desirability data were as follows:

Time Frame Frequency Distribution

\begin{tabular}{|l|c|c|c|c|c|c|c|}
\hline & $\mathrm{N}$ & $\begin{array}{c}1999- \\
2000\end{array}$ & $\begin{array}{c}2001- \\
2010\end{array}$ & $\begin{array}{c}2011- \\
2020\end{array}$ & $\begin{array}{c}\text { After } \\
2020\end{array}$ & Never & NR \\
\hline Round 2 & 43 & 0 & 7 & 7 & 15 & 14 & 0 \\
\hline Round 3 & 42 & 0 & 4 & 3 & 27 & 8 & 0 \\
\hline
\end{tabular}

Impact Distribution

Very Low
\begin{tabular}{|c|c|c|c|c|c|c|}
\hline 1 & 2 & 3 & 4 & 5 & 6 & 7 \\
\hline 5 & 5 & 6 & 12 & 5 & 2 & 6 \\
\hline
\end{tabular}

No Response $=2$

Mean Impact Rating $=3.90$

Desirability Distribution

Very Low
\begin{tabular}{|c|c|c|c|c|c|c|}
\hline 1 & 2 & 3 & 4 & 5 & 6 & 7 \\
\hline 13 & 7 & 5 & 6 & 4 & 3 & 4 \\
\hline
\end{tabular}

No Response $=1$

Mean Desirability Rating $=3.14$ 
Earlier responses in both the 2001-2010 and 2011-2020 categories viewed this event as occurring soonest because “we've always underestimated the speed with which newer technologies become available." Another noted that "This technology is just a few years away virtual reality will soon be in all our schools therefore it's a matter of time until avatars are in place." One respondent in the "After 2020" time frame warned that "There is a backlash to using 'heros' to teach anything." Those who said this event would never occur stated that "Teachers will continue to be localized, even though software packages may be developed to allow this kind of interaction. Parents want real people" and warned "Think of the social implications!" Others responded "This is just plain silly.," and "Get real."

Event 41 projected that "School to work will be scrapped." Time, impact, and desirability data were as follows:

Time Frame Frequency Distribution

\begin{tabular}{|l|c|c|c|c|c|c|c|}
\hline & N & $\begin{array}{c}1999- \\
2000\end{array}$ & $\begin{array}{c}2001- \\
2010\end{array}$ & $\begin{array}{c}2011- \\
2020\end{array}$ & $\begin{array}{c}\text { After } \\
2020\end{array}$ & Never & NR \\
\hline Round 2 & 43 & 0 & 13 & 7 & 6 & 16 & 1 \\
\hline Round 3 & 42 & 0 & 11 & 7 & 18 & 6 & 0 \\
\hline
\end{tabular}

\section{Impact Distribution}

Very Low
\begin{tabular}{|c|c|c|c|c|c|c|}
\hline 1 & 2 & 3 & 4 & 5 & 6 & 7 \\
\hline 5 & 1 & 5 & 13 & 5 & 5 & 6 \\
\hline
\end{tabular}

No Response $=3$

Mean Impact Rating $=4.28$ 


\section{Desirability Distribution}

Very Low
\begin{tabular}{|c|c|c|c|c|c|c|}
\hline 1 & 2 & 3 & 4 & 5 & 6 & 7 \\
\hline 11 & 3 & 7 & 11 & 4 & 1 & 3 \\
\hline
\end{tabular}

No Response $=3$

Mean Desirability Rating $=3.23$

The earliest predictions for this event was in the 2001-2010 time frame. Reasons cited included the expiration of federal funding for this program in the year 2000. School-To-Work "Will need to be funded by state and local dollars, or federal vocational education and training dollars." Another respondent stated "The federal government and state legislature will not reauthorize the funds and it will die without the money." Other responses centered on the idea that School-To-Work has recently met with an increasing amount of resistance. One respondent from the 2011-2020 time frame stated that School-To-Work would be scrapped because of "Changing trends; liability issues." Those who felt the event would never occur mentioned School-To-Work was "Too enculturated to drop" and that "Some form of School-To-Work will always be a part of the curriculum - It may not be called School-To-Work but the concepts will remain in our curriculum." Another cited that "Business will continue to exert standards/expectations of school systems."

Event 89 projected that "Professional tenure for teachers will be eliminated." Time, impact, and desirability data were as follows: 
Time Frame Frequency Distribution

\begin{tabular}{|l|c|c|c|c|c|c|c|}
\hline & $\mathrm{N}$ & $\begin{array}{c}1999- \\
2000\end{array}$ & $\begin{array}{c}2001- \\
2010\end{array}$ & $\begin{array}{c}2011- \\
2020\end{array}$ & $\begin{array}{c}\text { After } \\
2020\end{array}$ & Never & NR \\
\hline Round 2 & 43 & 0 & 8 & 12 & 8 & 15 & 0 \\
\hline Round 3 & 42 & 0 & 7 & 6 & 20 & 9 & 0 \\
\hline
\end{tabular}

\section{$\underline{\text { Impact Distribution }}$}

Very Low
\begin{tabular}{|c|c|c|c|c|c|c|}
\hline 1 & 2 & 3 & 4 & 5 & 6 & 7 \\
\hline 1 & 0 & 3 & 6 & 8 & 6 & 18 \\
\hline
\end{tabular}

No Response $=1$

Mean Impact Rating $=5.62$

Desirability Distribution

Very Low
\begin{tabular}{|c|c|c|c|c|c|c|}
\hline 1 & 2 & 3 & 4 & 5 & 6 & 7 \\
\hline 5 & 4 & 1 & 3 & 6 & 4 & 19 \\
\hline
\end{tabular}
$\begin{gathered}\text { No Response }=1 \\
\text { Mesirability Rating }=5.12\end{gathered}$

Comments from the 2001-2010 group mentioned "teacher shortages" as a possible reason for this event. One stated "We actually do not have tenure now." This was considered an essential change "for the state to have a competitive educational system. Poor education will be the result of a poor state unless personnel laws are revised." Another respondent from the 20112020 time frame commented that the elimination of teacher tenure would be the "Inevitable result of a decade of frustrating results." "Professional employee groups will fight this tooth and nail" 
through their lobby efforts was offered as the reason this event would never occur.

\section{After 2020 Time Frame Summary}

Of the five events in the "After 2020" time frame, none met the criteria as primary events for inclusion in the scenario. Event 89 qualified as a High Impact and High Desirability event; number 8 was in the High Impact category, and Number 28 qualified as a High Impact, Low Desirability event.

\section{Never Time Frame}

Eleven events were included in the "Never" time frame. They are again presented as they appeared on the Round 2 and 3 survey instruments. The number assigned to each event denotes its numerical placement on those survey instruments.

Event 1 projected that "Local county boards of education (with five members) will be replaced by seven or nine-member boards." Time, impact, and desirability data were as follows:

Time Frame Frequency Distribution

\begin{tabular}{|l|c|c|c|c|c|c|c|}
\hline & $\mathrm{N}$ & $\begin{array}{c}1999- \\
2000\end{array}$ & $\begin{array}{c}2001- \\
2010\end{array}$ & $\begin{array}{c}2011- \\
2020\end{array}$ & $\begin{array}{c}\text { After } \\
2020\end{array}$ & Never & NR \\
\hline Round 2 & 43 & 0 & 10 & 4 & 3 & 26 & 0 \\
\hline Round 3 & 42 & 0 & 6 & 2 & 3 & 31 & 0 \\
\hline
\end{tabular}




\section{Impact Distribution}

Very Low
\begin{tabular}{|c|c|c|c|c|c|c|}
\hline 1 & 2 & 3 & 4 & 5 & 6 & 7 \\
\hline 12 & 5 & 2 & 11 & 5 & 1 & 4 \\
\hline
\end{tabular}

No Response $=3$

Mean Impact Rating $=3.28$

Desirability Distribution

Very Low
\begin{tabular}{|c|c|c|c|c|c|c|}
\hline 1 & 2 & 3 & 4 & 5 & 6 & 7 \\
\hline 22 & 7 & 2 & 5 & 3 & 1 & 1 \\
\hline
\end{tabular}

No Response $=2$

Mean Desirability Rating $=2.20$

Responses in the "2001-2011" group suggested that the number of board members in small counties would remain at 5, and increase to 7 with a school population above 25,000, and 9 above 50,000. Also mentioned were situations affected by consolidation which "may result in need to increase number of school board members where consolidation involves schools across county lines." Another panelist commented "Board majority switches too easily - most are 3-2 boards." Panelists who commented from the "2011-2020" and "After 2020" groups simply stated "Believe it is possible" and "Never say never," respectively.

Event 2 projected that "There will be non-partisan primary and general election of local school boards." Time, impact, and desirability data were as follows: 
$\underline{\text { Time Frame Frequency Distribution }}$

\begin{tabular}{|l|c|c|c|c|c|c|c|}
\hline & $\mathrm{N}$ & $\begin{array}{c}1999- \\
2000\end{array}$ & $\begin{array}{c}2001- \\
2010\end{array}$ & $\begin{array}{c}2011- \\
2020\end{array}$ & $\begin{array}{c}\text { After } \\
2020\end{array}$ & Never & NR \\
\hline Round 2 & 43 & 0 & 2 & 11 & 5 & 23 & 2 \\
\hline Round 3 & 42 & 0 & 2 & 4 & 4 & 31 & 1 \\
\hline
\end{tabular}

\section{$\underline{\text { Impact Distribution }}$}

Very Low
\begin{tabular}{|c|c|c|c|c|c|c|}
\hline 1 & 2 & 3 & 4 & 5 & 6 & 7 \\
\hline 12 & 2 & 5 & 6 & 7 & 2 & 5 \\
\hline
\end{tabular}

No Response $=4$

Mean Impact Rating $=3.51$

Desirability Distribution

\begin{tabular}{l} 
Very Low \\
\begin{tabular}{|c|c|c|c|c|c|c|}
\hline 1 & 2 & 3 & 4 & 5 & 6 & 7 \\
\hline 19 & 3 & 3 & 5 & 5 & 2 & 3 \\
\hline
\end{tabular} No Response $=3$ \\
\hline
\end{tabular}

Respondents from the "2011-2020" time frame noted that there would be "Increased national movement away from politics and toward issues," and that "The proliferation of candidates with plurality rather than majority winners will result in election of bizarre candidates which will induce the legislature to use the primary to narrow the field." The legislature's "tiring of non-responsive boards" was cited as a reason for occurrence in the "After 2020" group, "and this could be a positive response." 
Event 10 projected that "School-based governance will erode the authority of local school boards." Time, impact, and desirability data were as follows:

\section{Time Frame Frequency Distribution}

\begin{tabular}{|l|c|c|c|c|c|c|c|}
\hline & $\mathrm{N}$ & $\begin{array}{c}1999- \\
2000\end{array}$ & $\begin{array}{c}2001- \\
2010\end{array}$ & $\begin{array}{c}2011- \\
2020\end{array}$ & $\begin{array}{c}\text { After } \\
2020\end{array}$ & Never & NR \\
\hline Round 2 & 43 & 1 & 13 & 7 & 0 & 22 & 0 \\
\hline Round 3 & 42 & 0 & 12 & 5 & 0 & 25 & 0 \\
\hline
\end{tabular}

\section{Impact Distribution}

Very Low
\begin{tabular}{|c|c|c|c|c|c|c|}
\hline 1 & 2 & 3 & 4 & 5 & 6 & 7 \\
\hline 6 & 1 & 2 & 7 & 14 & 9 & 5 \\
\hline
\end{tabular}

Mean Impact Rating $=4.57$

\section{Desirability Distribution}

Very Low
\begin{tabular}{|c|c|c|c|c|c|c|}
\hline 1 & 2 & 3 & 4 & 5 & 6 & 7 \\
\hline 9 & 3 & 7 & 9 & 6 & 7 & 2 \\
\hline
\end{tabular}

Mean Desirability Rating $=3.67$

Those responding from both the 2001-2010 and 2011-2020 time frames indicated that this event has already begun and likely will continue. "There is already evidence of this erosion although it has been slow but steady over the past several years, e.g. Faculty Senate Days, Professional Development Councils, Stanford 9 test expectations, un-announced credential audits, 
SDE takeovers of the Logan and Mingo county systems, etc." As the trend continues, "School boards can and will likely continue to exist" but "Professionals will take more control of their profession as doctors and lawyers have done." Regarding the continuation of the trend, one stated "Devolution is wave of future. Centralized control operates against the world wide trend to local control of schools, government, taxes, etc. LSIC's will become the 'school board,' as in charter schools.” Because of this, “'Local schools will be given more responsibility and held accountable for student performance, etc."

Event 12 projected that "The Legislature will deregulate education." Time, impact, and desirability data were as follows:

Time Frame Frequency Distribution

\begin{tabular}{|l|c|c|c|c|c|c|c|}
\hline & $\mathrm{N}$ & $\begin{array}{c}1999- \\
2000\end{array}$ & $\begin{array}{c}2001- \\
2010\end{array}$ & $\begin{array}{c}2011- \\
2020\end{array}$ & $\begin{array}{c}\text { After } \\
2020\end{array}$ & Never & NR \\
\hline Round 2 & 43 & 0 & 3 & 5 & 7 & 28 & 0 \\
\hline Round 3 & 42 & 0 & 2 & 4 & 4 & 32 & 0 \\
\hline
\end{tabular}

\section{Impact Distribution}

Very Low
\begin{tabular}{|c|c|c|c|c|c|c|}
\hline 1 & 2 & 3 & 4 & 5 & 6 & 7 \\
\hline 0 & 0 & 0 & 2 & 4 & 10 & 25 \\
\hline
\end{tabular}

No Response $=2$

Mean Impact Rating $=6.41$ 


\section{Desirability Distribution}

Very Low
\begin{tabular}{|c|c|c|c|c|c|c|}
\hline 1 & 2 & 3 & 4 & 5 & 6 & 7 \\
\hline 9 & 4 & 4 & 5 & 2 & 4 & 14 \\
\hline
\end{tabular}

\section{No Response $=1$}

Mean Desirability Rating $=4.31$

Comments from the 2001-2010 time frame cited "devolution is the wave of the future," and that "education will undergo major changes in the future and as a result deregulation will occur." Those responding from the 2011-2020 category indicated that the Legislature "will continue to over legislate until it must deregulate in order to maintain public schools." It was suggested that this would lead to the emergence of charter schools and the deregulation of "the school personnel section of code 18A in exchange for teacher success and school success with all students."

Event 27 projected that "The emphasis on computer skills will diminish when it is realized that computers are simply tools for well-prepared educators to use and they do not teach students to think, read, write, appreciate the arts, challenge and improvise." Time, impact, and desirability data were as follows:

Time Frame Frequency Distribution

\begin{tabular}{|l|c|c|c|c|c|c|c|}
\hline & N & $\begin{array}{c}1999- \\
2000\end{array}$ & $\begin{array}{c}2001- \\
2010\end{array}$ & $\begin{array}{c}2011- \\
2020\end{array}$ & $\begin{array}{c}\text { After } \\
2020\end{array}$ & Never & NR \\
\hline Round 2 & 43 & 0 & 9 & 7 & 2 & 25 & 0 \\
\hline Round 3 & 42 & 0 & 5 & 3 & 2 & 32 & 0 \\
\hline
\end{tabular}




\section{Impact Distribution}

Very Low
\begin{tabular}{|c|c|c|c|c|c|c|}
\hline 1 & 2 & 3 & 4 & 5 & 6 & 7 \\
\hline 4 & 2 & 1 & 9 & 8 & 4 & 10 \\
\hline
\end{tabular}

No Response $=5$

Mean Impact Rating $=4.76$

Desirability Distribution

Very Low
\begin{tabular}{|c|c|c|c|c|c|c|}
\hline 1 & 2 & 3 & 4 & 5 & 6 & 7 \\
\hline 13 & 6 & 1 & 4 & 3 & 5 & 8 \\
Mean Desirability Rating = 3.63 High
\end{tabular}
No Response $=3$

Responses from the "2001-2010," "2011-2020,” and “After 2020" time frames generally agreed that "Once nearly everyone becomes comfortable and familiar, less skills training will be needed in schools and it will cease to be a novelty." Another reason cited was that "students will have the skills early in their schooling and will not need to be taught in later years." Others mentioned the "newness and trendiness of computers" which will eventually find its own level and "not necessarily overpower the teaching process as it is projected to do by some." One respondent commented "Remember the video technology fad of the 60s - - it was going to revolutionize education. It didn't. Neither will this."

Event 64 projected that "Teacher salaries in WV will rise above the national average." Time, impact, and desirability data were as follows: 
$\underline{\text { Time Frame Frequency Distribution }}$

\begin{tabular}{|l|c|c|c|c|c|c|c|}
\hline & $\mathrm{N}$ & $\begin{array}{c}1999- \\
2000\end{array}$ & $\begin{array}{c}2001- \\
2010\end{array}$ & $\begin{array}{c}2011- \\
2020\end{array}$ & $\begin{array}{c}\text { After } \\
2020\end{array}$ & Never & NR \\
\hline Round 2 & 43 & 0 & 10 & 3 & 2 & 28 & 0 \\
\hline Round 3 & 42 & 0 & 7 & 3 & 1 & 31 & 0 \\
\hline
\end{tabular}

\section{$\underline{\text { Impact Distribution }}$}

Very Low
\begin{tabular}{|c|c|c|c|c|c|c|}
\hline 1 & 2 & 3 & 4 & 5 & 6 & 7 \\
\hline 2 & 1 & 3 & 6 & 7 & 11 & 10 \\
\hline
\end{tabular}

No Response $=3$

Mean Impact Rating $=5.20$

Desirability Distribution

Very Low
\begin{tabular}{|c|c|c|c|c|c|c|}
\hline 1 & 2 & 3 & 4 & 5 & 6 & 7 \\
\hline 2 & 2 & 1 & 4 & 3 & 7 & 21 \\
\hline
\end{tabular}

No Response $=3$

Mean Desirability Rating $=5.73$

Respondents from the "2001-2010" time frame generally indicated that teacher salaries in

West Virginia will have to continue to move higher or we will experience difficulties in obtaining teachers. Another mentioned that "We will have severe shortages in some certifications which will drive salaries up." Another panelist cautioned that "West Virginia will not fare well in a declining world economy, nor will its teachers' salaries." In the "2011-2020" time frame, respondents related to the intensification of the teacher shortage will cause West Virginians to 
value their teachers, making them willing to pay "about the national average" to attract and keep them. "An improved per-capita income in WV will lift teacher pay."

Event 73 projected that "Private schools will not be able to select or discriminate among students." Time, impact, and desirability data were as follows:

\section{Time Frame Frequency Distribution}

\begin{tabular}{|l|c|c|c|c|c|c|c|}
\hline & $\mathrm{N}$ & $\begin{array}{c}1999- \\
2000\end{array}$ & $\begin{array}{c}2001- \\
2010\end{array}$ & $\begin{array}{c}2011- \\
2020\end{array}$ & $\begin{array}{c}\text { After } \\
2020\end{array}$ & Never & NR \\
\hline Round 2 & 43 & 1 & 4 & 9 & 1 & 27 & 1 \\
\hline Round 3 & 42 & 1 & 4 & 5 & 2 & 30 & 0 \\
\hline
\end{tabular}

\section{Impact Distribution}

Very Low
\begin{tabular}{|c|c|c|c|c|c|c|}
\hline 1 & 2 & 3 & 4 & 5 & 6 & 7 \\
\hline 2 & 3 & 3 & 12 & 2 & 3 & 14 \\
\hline
\end{tabular}

No Response $=4$

Mean Impact Rating $=4.90$

\section{Desirability Distribution}

\begin{tabular}{l} 
Very Low \\
\begin{tabular}{|c|c|c|c|c|c|c|}
\hline 1 & 2 & 3 & 4 & 5 & 6 & 7 \\
\hline 9 & 2 & 2 & 6 & 2 & 6 & 12 \\
\hline
\end{tabular} \\
Mean Desponse $=4$ \\
\hline
\end{tabular}

The 1999-2000 respondent indicated, "Private schools currently employ standards for 
admission." Comments from the 2001-2010 time frame included that "If state and federal funds come as vouchers, etc., the rules will come with it," and "If they (private schools) want public funds they will have to meet same standards." Comments from the 2011-2020 time frame generally agreed. Their comments included "Private schools seek and use public dollars either directly or indirectly;" "As private schools receive state/federal funds, control will follow," and "Court cases will force this issue."

Event 75 projected that "The state will audit and continue to set standards, but the private sector will deliver the services (through computer assisted instruction)." Time, impact, and desirability data were as follows:

Time Frame Frequency Distribution

\begin{tabular}{|l|c|c|c|c|c|c|c|}
\hline & $\mathrm{N}$ & $\begin{array}{c}1999- \\
2000\end{array}$ & $\begin{array}{c}2001- \\
2010\end{array}$ & $\begin{array}{c}2011- \\
2020\end{array}$ & $\begin{array}{c}\text { After } \\
2020\end{array}$ & Never & NR \\
\hline Round 2 & 43 & 0 & 5 & 9 & 6 & 22 & 1 \\
\hline Round 3 & 42 & 0 & 3 & 5 & 6 & 28 & 0 \\
\hline
\end{tabular}

\section{Impact Distribution}

Very Low
\begin{tabular}{|c|c|c|c|c|c|c|}
\hline 1 & 2 & 3 & 4 & 5 & 6 & 7 \\
\hline 1 & 2 & 0 & 6 & 6 & 11 & 12 \\
\hline
\end{tabular}

No Response $=5$

Mean Impact Rating $=5.50$ 


\section{Desirability Distribution}

Very Low
\begin{tabular}{|c|c|c|c|c|c|c|}
\hline 1 & 2 & 3 & 4 & 5 & 6 & 7 \\
\hline 15 & 9 & 6 & 3 & 1 & 2 & 2 \\
\hline
\end{tabular}

No Response $=5$

Mean Desirability Rating $=2.47$

All minority respondents agreed that the private sector will deliver educational services, as evidenced by the current use of computer software available $\mathrm{n}$ the schools today.

Event 101 projected that "The Rule of 80 will be passed by the Legislature." Time, impact, and desirability data were as follows:

\section{Time Frame Frequency Distribution}

\begin{tabular}{|l|c|c|c|c|c|c|c|}
\hline & $\mathrm{N}$ & $\begin{array}{c}1999- \\
2000\end{array}$ & $\begin{array}{c}2001- \\
2010\end{array}$ & $\begin{array}{c}2011- \\
2020\end{array}$ & $\begin{array}{c}\text { After } \\
2020\end{array}$ & Never & NR \\
\hline Round 2 & 43 & 1 & 9 & 8 & 3 & 21 & 1 \\
\hline Round 3 & 42 & 0 & 5 & 6 & 3 & 28 & 0 \\
\hline
\end{tabular}

\section{$\underline{\text { Impact Distribution }}$}

Very Low
\begin{tabular}{|c|c|c|c|c|c|c|}
\hline 1 & 2 & 3 & 4 & 5 & 6 & 7 \\
\hline 3 & 1 & 1 & 7 & 9 & 4 & 13 \\
\hline
\end{tabular}

No Response $=5$

Mean Impact Rating $=5.16$ 


\section{Desirability Distribution}

Very Low
\begin{tabular}{|c|c|c|c|c|c|c|}
\hline 1 & 2 & 3 & 4 & 5 & 6 & 7 \\
\hline 6 & 3 & 3 & 9 & 4 & 4 & 9 \\
\hline
\end{tabular}

No Response $=5$

Mean Desirability Rating $=4.32$

Respondents from the "2001-2010" group viewed this event as realistic stating "The economics of clearing out expensive veterans will supplant the current fears." Another said it was an "Inevitable political gift to unions." Panelists in the "2011-2020" category indicated that this event would depend on an improving economy. Those who estimated the event in the "After 2020" time frame mentioned that "The retirement program will be more solvent after Baby Boomers diminish in numbers and make it financially possible." One stated that this would be possible since "\$70 million in tobacco settlement frees much funding."

Event 105 projected that "Collective bargaining will be enacted." Time, impact, and desirability data were as follows:

Time Frame Frequency Distribution

\begin{tabular}{|l|c|c|c|c|c|c|c|}
\hline & N & $\begin{array}{c}1999- \\
2000\end{array}$ & $\begin{array}{c}2001- \\
2010\end{array}$ & $\begin{array}{c}2011- \\
2020\end{array}$ & $\begin{array}{c}\text { After } \\
2020\end{array}$ & Never & NR \\
\hline Round 2 & 43 & 0 & 6 & 12 & 4 & 20 & 1 \\
\hline Round 3 & 42 & 0 & 4 & 8 & 5 & 25 & 0 \\
\hline
\end{tabular}




\section{Impact Distribution}

Very Low
\begin{tabular}{|c|c|c|c|c|c|c|}
\hline 1 & 2 & 3 & 4 & 5 & 6 & 7 \\
\hline 3 & 0 & 1 & 4 & 5 & 9 & 16 \\
\hline
\end{tabular}

No Response $=5$

Mean Impact Rating $=5.61$

Desirability Distribution

Very Low
\begin{tabular}{|c|c|c|c|c|c|c|}
\hline 1 & 2 & 3 & 4 & 5 & 6 & 7 \\
\hline 19 & 5 & 5 & 3 & 2 & 2 & 2 \\
Mean Desirability Rating $=2.42$
\end{tabular}

Respondents from the earliest category, 2001-2010, mentioned this would occur because of the "Lobbying efforts of education organizations" and that "Inevitably West Virginia joins surrounding states." Those in the 2011-2020 category who commented attributed the change to the make-up of the legislature, and that it would occur "As employers struggle to regain authority, the response of unions may force this mediation." Another stated "Collective bargaining will be possible after blue collar and white collar workers with low pay and poor health benefits unite. Collective bargaining may also be redefined with management a partner, rather than enemy, especially on a society of life-long learners." Panelists from the "After 2020" category agreed that "Pressure from unions and other states" would help force this issue.

Event 120 projected that "Prayer will return to the public schools." Time, impact, and desirability data were as follows: 
$\underline{\text { Time Frame Frequency Distribution }}$

\begin{tabular}{|l|c|c|c|c|c|c|c|}
\hline & $\mathrm{N}$ & $\begin{array}{c}1999- \\
2000\end{array}$ & $\begin{array}{c}2001- \\
2010\end{array}$ & $\begin{array}{c}2011- \\
2020\end{array}$ & $\begin{array}{c}\text { After } \\
2020\end{array}$ & Never & NR \\
\hline Round 2 & 43 & 0 & 3 & 0 & 2 & 37 & 1 \\
\hline Round 3 & 42 & 0 & 2 & 0 & 2 & 38 & 0 \\
\hline
\end{tabular}

$\underline{\text { Impact Distribution }}$

Very Low

\begin{tabular}{|c|c|c|c|c|c|c|}
\hline 1 & 2 & 3 & 4 & 5 & 6 & 7 \\
\hline 10 & 4 & 5 & 4 & 1 & 4 & 8 \\
\hline
\end{tabular}

No Response $=7$

Mean Impact Rating $=3.72$

Desirability Distribution

Very Low
\begin{tabular}{|c|c|c|c|c|c|c|}
\hline 1 & 2 & 3 & 4 & 5 & 6 & 7 \\
\hline 13 & 2 & 2 & 6 & 5 & 2 & 6 \\
\hline
\end{tabular}

No Response $=7$

Mean Desirability Rating $=3.50$

Three minority panelists commented on this event. From the 2001-2010 time frame, one stated "I think we're going to have a backlash." The other panelists were from the "After 2020" category and said "Eventually it will happen," and "The Christian Coalition is very strong." 


\section{Never Time Frame Summary}

Of the eleven events included in the "Never" time frame, only number 120 qualified as a primary event and for inclusion in the scenario. It did not qualify, however, for inclusion as a High Impact, High Desirability, or Low Desirability event.

Event 69 met the criteria for inclusion in the High Impact and High Desirability category, and numbers 12 and 101 were in the High Impact category. High Impact and Low Desirability events included numbers 75 and 105, and numbers 1 and 2 were identified as Low Desirability events.

The organization and presentation of the data in Chapter 4 will be used to develop the scenarios, draw conclusions, and make recommendations in Chapter 5. 


\section{CHAPTER 5}

\section{Scenario, Summary, Conclusions and Recommendations}

Based on the data presented in Chapter 4, a scenario can be developed for each time frame. Chapter 5 also will contain a summary of the research project, conclusions based on the data, and recommendations for further research.

\section{Scenario}

A scenario can be developed on the future of public education in West Virginia based on the events generated by experts during Round 1 of the Delphi and their subsequent assessment of those events in Rounds 2 and 3. Responses from the experts enabled the investigator to project time frames and determine the level of impact and desirability for each event. The scenario is comprised of all primary ( $80+$ percent consensus) and secondary events (60 to 79 percent consensus) which have been arranged by time frame and organized by topical area. Topical areas include Students, Personnel, Curriculum, Governance, Facilities, Finance, School-Community Relations, Technology, and Miscellaneous. Events within each topical area are further divided into categories including High Impact and High Desirability, High Impact, High Desirability, High Impact and Low Desirability, and Low Desirability.

The only time frames which contain primary events are "2001- 2010" and "Never." These 
two time frames will be analyzed in relation to the events which met the criteria for the above named categories. The remaining events, whose impact and desirability ratings were insignificant, are summarized at the conclusion of each time frame. All secondary events within each time frame are also presented.

The "1999-2000" time frame contains no events, and the "2011-2020" and "After 2020" time frames contain only secondary events.

In presenting the events within each time frame and topical area, only those impact and desirability categories which contain events are included.

\section{Intermediate Range Time Frame, 2001-2010}

This time frame was most frequently designated as the probable time of occurrence of forty-six projected primary events. A total of eighteen events met the High Impact and High Desirability criteria; eight were High Impact; six were High Desirability; two were High Impact and Low Desirability, and four were considered Low Desirability. The remaining eight events failed to meet the criteria and are listed as "Other" events. A total of thirty-three secondary events were also projected to occur during this time frame, although by a lesser percentage of consensus.

\section{Students - Primary Events}

High Impact and High Desirability Projections

In the area of Students, three primary events qualified in the High Impact and High Desirability category. Events 24 and 48 represent the possibility of increased accountability for student achievement and behavior. Event 112 supports the emergence of student assistance 
programs.

24. $\left(\mathrm{O}_{\mathrm{I}}=5.98, \mathrm{O}_{\mathrm{D}}=5.61\right)$ "Accountability standards for all students will be enacted."

Accountability standards for students, in whatever form they might appear, would represent another phase of the ongoing school reform movement. This event would represent greater expectations toward meeting world-class standards for students and would be an increase over and above the number of accountability standards already in place in West Virginia. The term "enacted" indicates that such increased accountability standards would be legislated and would, therefore, apply statewide. One way this event might be achieved would be through implementation of event 37 (Curriculum, High Impact) which deals with increases in high school graduation requirements.

48. $\left(\mathrm{O}_{\mathrm{I}}=5.42, \mathrm{O}_{\mathrm{D}}=6.19\right) \quad$ "Students will be held more accountable for questionable behavior."

Increased accountability expectations are also projected to apply to student behavior. Recent events which have received extensive media coverage have focused national attention on deviant student behavior. This heightened attention to behavior will certainly contribute to the occurrence of this event in whatever way it manifests itself. If, however, "the violence, moral decay, drugs, disruptions and lack of discipline that well-meaning students are presently subjected to in our public schools" continues, we are likely to "see more private schools (event 72, Governance, Low Desirability) and new interest in vouchers (event 69, Finance, High Impact, Low Desirability)." Related at least in part to student accountability for questionable behavior is 
event 112 (Students, High Impact and High Desirability).

112. $\left(\mathrm{O}_{\mathrm{I}}=5.07, \mathrm{O}_{\mathrm{D}}=5.59\right)$ "Comprehensive student advisement programs will be developed."

Organized by teachers, guidance counselors, principals and central office administrators, student advisement programs have emerged to provide a variety of student assistance and support services including, but not limited to, clothing distribution, peer counseling, tutoring and problem mediation. The current success of school student assistance programs is the primary reason for their widespread appeal. Such programs, based on consensus, could have high impact and be highly desirable in dealing internally with various student problems on a student-to-student basis. This event represents early attempts to make students more accountable for their own behavior as projected by event 48 (Students, High Impact and High Desirability).

\section{High Impact Projections}

In the area of Students, one primary event qualified in the High Impact category. 36. $\left(\mathrm{O}_{\mathrm{I}}=5.21, \mathrm{O}_{\mathrm{D}}=4.53\right)$ "More emphasis will be placed on assessment of student
performance including test scores, skills, and trades."

Related to event 24 (Students, High Impact and High Desirability) on accountability standards, this event may occur because of increased public scrutiny of student achievement. The basic question in the mind of the public is "can our graduates actually do something?" While the panelists projected this event as having high impact, it was not of a significant enough level to warrant the High Desirability category. The reason for this may be the extra time involved in actually assessing, interpreting and recording "test scores, skills, and trades." 
Students - Secondary Events

High Impact and High Desirability Projections

Two secondary events qualified for inclusion in the High Impact and High Desirability category.

111. $\left(0_{\mathrm{I}}=5.44,0_{\mathrm{D}}=6.33\right) \quad$ "There will be a national insistence on the return to civility in schools."

The public looks to the public schools to provide an orderly environment in which learning can take place. As highly publicized school tragedies take place, the pendulum may swing toward higher expectations on schools to maintain control. The American education system is a public one which the public will not surrender to unruly students. Although it appears that for this event to occur, it should be preceded by a national return to civility. The literature, including the findings of this study, indicates that schools will increasingly be expected to solve our nation's social problems, implying that the "return to civility" may well begin in the schools.

115. $\left(0_{\mathrm{I}}=5.13,0_{\mathrm{D}}=5.36\right) \quad$ "Laws governing the discipline of special educations students will be relaxed."

This event has a High Impact and High Desirability rating because of the cumbersome and sometimes overburdening regulations that govern the discipline of special education students. Some relaxation would facilitate dealing more efficiently with these problems, while too much relaxation might endanger or compromise the rights of special education students and their parents currently afforded by federal law. One respondent indicated that there will be "continued blurring of the distinction between general and special education students."

High Impact Projections 
One secondary event qualified for inclusion in the High Impact category.

47. $\left(\mathrm{O}_{\mathrm{I}}=5.07, \mathrm{O}_{\mathrm{D}}=4.38\right)$ "There will be an increase in discipline problems and need for alternative education programs."

The national insistence on improving student behavior and the projected rise in discipline problems may prove to be the catalyst for the West Virginia Board of Education and West Virginia Department of Education to encourage county school systems to increase the number and availability of alternative education programs. This event may be viewed as a trade-off to county school administrators in that alternative programs will create less disruptive classrooms, but such programs are expensive to operate. This event is related to primary event 48 (Students, High Impact and High Desirability) which addresses students being held more accountable for questionable behavior.

High Impact and Low Desirability Projections

There was one secondary event which qualified for inclusion in the High Impact and Low Desirability Projections.

123. $\left(\mathrm{O}_{\mathrm{I}}=5.81, \mathrm{O}_{\mathrm{D}}=1.57\right)$ "There will be a continued out-migration to other states by high school and college graduates, and young families with children."

The low desirability of this event relates to a decrease in the supply of college and high school graduates in the available labor pool, a reduction in the number of potential school-aged children, a lower tax base, and an increase in the median age of West Virginia residents. Implications of this event might be a negative image of the state presented to potential business and industry because of an inadequate labor force, a possible reduction in school revenues and an increase in funding for programs for the elderly. All of these possibilities are consistent with the 
literature.

\section{Personnel - Primary Events}

High Impact and High Desirability Projections

In the area of Personnel, six primary events qualified in the High Impact and High Desirability category.

45. $\left(0_{I}=5.11, O_{D}=5.73\right)$ "State certification will be required for pre-school teachers."

This event, although exceeding the 80 percent consensus for inclusion as a primary event, is already required, according to officials with the West Virginia Department of Education. Considering the number of respondents who considered this such a necessary event, the investigator must assume that (1) the respondents simply did not know that pre-school certification is already required, or that (2) the respondents misinterpreted this event to mean private, not public, pre-school teachers. Nevertheless, there are already certification requirements for public school pre-school teachers in West Virginia.

65. $\left(\mathrm{O}_{\mathrm{I}}=5.29, \mathrm{O}_{\mathrm{D}}=5.32\right) \quad$ "Staff development will require paid additional/extended days for teachers."

Staff development, a requirement for all teachers in West Virginia, is an essential element for maintaining and enhancing their capabilities. It has often been argued that, for staff development to be effective, it must be given some level of priority and should be delivered in a consistent manner based on the needs of those involved as participants. Often this is not the case in practice, particularly when there is a considerable time span between sessions, and teachers are permitted to attend the sessions of their own choosing which may or may not relate to actual 
needs. Additional or extended days for teachers solely devoted to staff development would assure that teachers were getting the proper experiences they need in uninterrupted, concentrated sessions.

90. $\left(0_{\mathrm{I}}=5.09, \mathrm{O}_{\mathrm{D}}=5.07\right)$ "There will be more flexibility of certification laws to allow for greater mobility to meet staffing demands including interstate and international licensure."

This event, which may be brought about by the occurrence of a statewide teacher shortage (Event 92, Personnel, High Impact and Low Desirability), actually infers two issues. The first, "flexibility of certification laws to allow greater mobility to meet staffing demands," would permit county school systems greater latitude in making teacher assignments, both within and between schools. Certification requirements may be relaxed to allow teachers to instruct in a wider variety of subject areas. The second, "interstate and international licensure," would permit greater mobility among teachers between states. This might not be as desirable as projected should a teacher shortage occur since other states may offer more pay, benefits and/or incentives to attract teachers.

97. $\left(O_{I}=5.56, O_{D}=5.33\right) \quad$ "Staffing limits under the state aid formula will increase." This event was generated in response to the difficulties county boards of education face when attempting to adequately staff their schools. Reductions in the staffing allowance of the formula occurred in 1988 which forced county boards of education to reduce staff, some through reductions in force. Since that time new program requirements which require staff have been imposed, but no allowance has been made to allow counties relief from the limitations of the 
formula. This event will be essential if the projected teacher shortage occurs (Event 92, Personnel, High Impact and Low Desirability).

100. $\left(0_{\mathrm{I}}=5.33, \mathrm{O}_{\mathrm{D}}=6.29\right)$ "There will be more emphasis on teaching as a profession." This event, which also relates to the projection of a statewide teacher shortage (Event 92, High Impact and Low Desirability), may be brought about by a number of issues. As mentioned in the "Students" section, an increase in accountability standards for student achievement and behavior will focus public attention on the teaching-learning process. This may cause the public to more fully realize what teachers are attempting to do and what impediments they must deal with. Once the impending teacher shortage begins and many school systems experience difficulty in maintaining a full compliment of teachers, the public will begin to realize the true value of those educators in their communities. The public, however, will continue to demand a higher quality education for their children and more professional teachers. Increased resources and teacher pay should also become available once the real value of teachers to society is realized.

119. $\left(\mathrm{O}_{\mathrm{I}}=5.23, \mathrm{O}_{\mathrm{D}}=5.85\right)$ "More retirees will become school volunteers."

The high impact and desirability of this event may be found in the experience that retirees can bring back to the school setting. Schools provide environments with which the retirees are familiar and offer situations where retirees can devote a portion of their time doing things with which they are familiar. Should the projected teacher shortage (Event 92, Personnel, High Impact and Low Desirability) occur, there will be an increased need for the services which retirees could provide. Volunteerism is not to be confused with "substituting," which requires significantly more 
time, cannot always be planned for, and is compensated. Panelists noted that if retirees felt they had to substitute for something to do, they would not have left their jobs in education in the first place.

\section{High Desirability Projections}

In the area of Personnel, one primary event qualified in the High Desirability category.

96. $\left(\mathrm{O}_{\mathrm{I}}=4.55, \mathrm{O}_{\mathrm{D}}=5.52\right)$ "There will be an increase in the number of females entering administrative positions."

The occurrence of this highly desirable event relates to the increasing number of females who now hold administrative certificates. This number has increased steadily since the 1970s. In many counties throughout West Virginia there is evidence of more females in administrative positions. According to the respondents, this event will occur slowly, but may accelerate if a statewide teacher shortage occurs (Event 92, Personnel, High Impact and Low Desirability).

\section{High Impact and Low Desirability Projections}

In the area of Personnel, two primary events qualified in the High Impact and Low Desirability category.

92. $\left(0_{I}=6.17, O_{D}=1.68\right)$ "There will be a statewide teacher shortage."

This primary event ranked as having the highest impact and the second lowest desirability rating of all events. A nationwide teacher shortage is consistent with the literature and is projected to reach its maximum level in West Virginia within this time frame. Factors contributing to the occurrence of this event included an increase in the number of teacher/administrator retirements and teachers leaving West Virginia for jobs in other states which 
offer higher salaries, benefits and incentives. Contributing to the low desirability rating would be the potential of having "less competent" individuals apply for teaching positions in West Virginia as the more qualified are attracted to other states or career fields. It is also anticipated that this shortage will affect rural areas and particular curriculum areas. Such a shortage in West Virginia would relate to more flexibility of certification laws to allow for greater mobility to meet staffing demands (Event 90, Personnel, High Impact and High Desirability), reductions of certification requirements (Event 93, Personnel, High Impact and Low Desirability), staffing limits under the state aid formula will increase (Event 97, Finance, High Impact and High Desirability), more emphasis on teaching as a profession (Event 100, Personnel, High Impact and High Desirability), retirement system restrictions will be relaxed to permit retirees to re-enter teaching (Event 103, Other), and more retirees will become school volunteers (Event 119, Personnel, High Impact and High Desirability). Secondary events 95 (a greater shortage of administrators than teachers) and 104 (teachers who do not have teaching certificates will be recruited from the private sector) also relate to the statewide teacher shortage.

93. $\left(\mathrm{O}_{\mathrm{I}}=5.76, \mathrm{O}_{\mathrm{D}}=2.61\right)$ "Certification requirements will be reduced during a teacher shortage."

In order to meet the demand for teachers during the projected teacher shortage, means will have to be found to facilitate the availability of a large number of teachers. Given that this is a primary event, the assumption is made by the investigator that the panelists felt that the current number of students graduating from teacher education programs will be insufficient to meet the projected need. If this be the case, some reduction in teacher certification requirements might be 
anticipated. This may also become necessary due to increased competition for quality teachers from other states. One of the secondary events, 43 (" All teacher training programs will take five years to complete.") would tend to contradict this primary event somewhat, especially considering the need to produce more teachers in a shorter time span as opposed to a longer teacher education program.

\section{Other Projections}

In the area of Personnel, two primary events which did not qualify for the high or low impact or desirability categories are listed in this section.

91. $\left(0_{I}=4.07, O_{D}=4.40\right)$ "Degree programs will be offered for administrators working in finance, transportation, and nutrition service."

Implementation of this event would require educational leadership programs at the state universities to expand their current staff and program offerings. Many of the respondents, while agreeing on the time frame of the occurrence of this event indicated that finance, transportation and nutrition service are best presented as modules within current programs and not as separate programs. Given the neutral impact and desirability ratings, this event would have little apparent effect on these positions within school systems.

103. $\left(\mathrm{O}_{\mathrm{I}}=4.73, \mathrm{O}_{\mathrm{D}}=4.73\right)$ "Retirement system restrictions will be relaxed to permit retired teachers to re-enter teaching to offset a teacher shortage."

The projected teacher shortage (Event 92, Personnel, High Impact and Low Desirability) will create a need for creative ways to increase the number of available teachers. The current regulations governing retirement restrict retirees from re-entering the teaching force by limiting 
the number of days that may be worked without loss of retirement benefits. Having a retiree reenter teaching on a full-time basis would cause immediate cancellation of benefits, and would cause the employee to begin paying back into the retirement system. Retirees might prefer to have the system freeze and pay their benefits upon retirement without penalty if they re-entered teaching. Creative ways to deal with this situation might include continuing to pay retirement benefits without requiring additional payments from current earnings, exempting retirees from working in excess of the current limitations, or contracting with retirees for teaching one or two classes per day.

\section{Personnel - Secondary Events}

High Impact and High Desirability Projections

Two secondary events qualified for inclusion in this category.

88. $\left(\mathrm{O}_{\mathrm{I}}=5.93, \mathrm{O}_{\mathrm{D}}=5.90\right)$ "There will be a return to 'best qualified,' not 'most senior,' when selecting teachers."

This secondary event is already written into the West Virginia Code (§18A-4-7a), but is widely misinterpreted. The Code states "the county board shall make decisions affecting the hiring of new classroom teachers on the basis of the applicant with the highest qualifications." What appears to the investigator to be the key word in the Code is the term "new." Seniority, or the amount of experience relevant to the position, is one of seven equal items which constitute qualifications. In the case of teacher transfer, seniority is also listed as one of the equally weighted considerations. The law stipulates, however, that "if the applicant with the most seniority is not selected for the position, upon the request of the applicant a written statement of reasons shall be given to the applicant with suggestions for improving the applicant's 
qualifications."272 Due to the seniority stipulations, it appears to the investigator that seniority is considered the most weighted of the "equal" considerations.

99. $\left(\mathrm{O}_{\mathrm{I}}=5.26, \mathrm{O}_{\mathrm{D}}=5.07\right)$ "There will be competency testing for teachers and administrators."

The High Impact and High Desirability rating of this secondary event may come from the desire of the panelists to insure that all teachers and administrators are of high quality.

Competency testing, however, may prove to identify teachers and administrators who are knowledgeable, but cannot teach or administer effectively. It is undetermined whether this event might apply only to new applicants or to currently practicing individuals as well. Competency testing may conflict somewhat with the projected teacher shortage (Event 92, High Impact and Low Desirability) as it may limit the number of available teachers.

\section{High Impact Projections}

One secondary event qualified for inclusion in this section.

104. $\left(0_{I}=5.27, O_{D}=3.17\right)$ "Teachers who do not have teaching certificates will be recruited from the private sector."

Occurrence of this event may depend on the projected statewide teachers shortage (Event 92, Personnel, High Impact and Low Desirability) and represents an effort to insure that all teaching vacancies are filled with the best qualified personnel available. The average desirability rating may reflect a degree of uncertainty about persons assuming teaching responsibilities without adequate preparation.

\footnotetext{
${ }^{272}$ School Laws of West Virginia. 1997. Charlottesville, The Michie Company, p. 340.
} 
High Impact and Low Desirability Projections

Two secondary events qualified for inclusion in this category.

95. $\left(0_{\mathrm{I}}=5.49, \mathrm{O}_{\mathrm{D}}=1.95\right)$ "There will be an even greater shortage of administrators than teachers."

Administrators will also contribute to the projected teacher shortage when they retire.

While many will need to be replaced, the important factor will be to have enough "good ones" available as vacancies occur. The shortage may also be aggravated by the need to employ additional assistant principals and guidance counselors as schools become larger (Secondary Event 78).

106. $\left(\mathrm{O}_{\mathrm{I}}=5.88, \mathrm{O}_{\mathrm{D}}=1.74\right)$ "There will be a loss of quality leadership due in part to lack of interest in the principalship by certified and qualified teachers."

While there may be some reduction in interest in principalships, many of the respondents indicated that there would be a lack of "good ones." Several respondents indicated that there would always be teachers interested in principalships for career advancement and increased salary.

\section{Curriculum - Primary Events}

High Impact and High Desirability Projections

In the area of Curriculum, two primary events qualified in the High Impact and High Desirability category.

42. $\left(0_{\mathrm{I}}=5.47, \mathrm{O}_{\mathrm{D}}=5.56\right)$ "Education will become more focused on teaching problem solving, access to data bases, and the use of technology."

This event is consistent with the literature on the future of education and the use of 
technology as a part of the curriculum. This event represents a shift in the mission of schools from the acquisition of facts and knowledge of a discipline to learning the use of technology to access world-wide, universally available databases, and then to use that information to solve problems. While there will remain an emphasis on mastering the basic skills, curricular concerns have already shifted toward teaching individual and group problem solving and reasoning skills, how to obtain available information, and the utilization of technology. The emphasis on problem solving will center on how to apply knowledge in various situations. The emergence of the Internet and the availability of an ever-increasing amount of data must also be taught if students are to be competitive in the global markets of the future. Technology is necessary for such access, and familiarity with various hardware components and types of software will be essential skills for students to master. The true value of technology comes when the student is empowered to take a more proactive role in the acquisition of knowledge. Technology was referred to by one panelist as "the newest basic skill." Staff development will be a critical need as teachers will require additional skills to facilitate this type of student learning. The extra need for staff development relates to the possibility of additional days added to the school year for such purposes (Event 65, Personnel, High Impact and High Desirability). One panelist suggested that “televisions and Internet systems will replace the need for as many teachers which, in turn, may require fewer administrators."

49. $\left(0_{\mathrm{I}}=5.05, \mathrm{O}_{\mathrm{D}}=5.65\right)$ "After-school programs will expand."

This event is also consistent with the literature and may occur in response to an increasing need for instructional time for some students, or as a means of providing after-school care for 
students whose parents are not at home at the end of the school day. Many after school programs currently offer academic assistance in the form of help with homework or remediation. Such assistance, when provided after school, may reduce the time necessary for such services during the instructional day. "Latch-key" students are also afforded an opportunity to remain at school in a safer environment and engage in some productive activity rather than being sent home to an empty house because, in many cases, the parent(s) is/are still at work. As one respondent pointed out, however, "As schools absorb more of the parents' responsibilities, such programs are desirable for children's security but ultimately may lead to parents taking even less responsibility."

\section{High Impact Projections}

Two primary events qualified for inclusion in the High Impact category.

34. $\left(0_{\mathrm{I}}=5.71,0_{\mathrm{D}}=4.43\right)$ "A state curriculum and standards will be established that will drive what is taught and tested."

Several respondents indicated that this event is, at least in part, currently in place with the West Virginia Instructional Goals and Objectives and the use of the SAT 9 as a measure of student achievement. Specific standards will need to be developed to assess mastery as the student progresses through the curriculum. The average desirability rating may reflect some resignation that the beginnings of this event are already in place, or that the event is representative of increasing centralized control by the West Virginia Department of Education and/or the West Virginia Board of Education.

37. $\left(\mathrm{O}_{\mathrm{I}}=5.12, \mathrm{O}_{\mathrm{D}}=4.81\right)$ "High school graduation requirements will increase."

Respondents indicated that additional numbers of basic courses in math, science, and 
computers will be considered requirements, not choices. Technology will be taught throughout the curriculum. The requirements of School-To-Work and the expanding availability of block scheduling have caused many schools to raise the number of credits required for graduation. School-To-Work has also placed additional requirements on students for mentorships, internships, and community service. While some refinement in these requirements should be expected to occur, the foundation for this event is already in place. This event also relates to increased accountability standards expressed in event 24 (Students, High Impact and High Desirability).

\section{High Desirability Projections}

Three events qualified for inclusion in the High Desirability category.

35. $\left(\mathrm{O}_{\mathrm{I}}=4.67, \mathrm{O}_{\mathrm{D}}=5.12\right)$ "The state assessment program will be revised."

The high desirability of this event may relate to a state curriculum and standards driving what is taught and tested (Event 34, Curriculum, High Impact) in that educators are interested in having a test which accurately measures student achievement in relation to what is taught. The current state/county testing program is in its third year of implementation and will remain in place under contract for the next two years. The current test instruments are now being considered for revision. Should primary event 42, (Curriculum, High Impact and High Desirability) addressing the redirection of education's becoming more focused on teaching problem solving, access to data bases, and the use of technology occur, educators would insist on an appropriate, fair and comprehensive test instrument that would adequately assess these areas. The outcome of this event will ultimately depend on the quality of the revisions in relation to their ability to accurately measure student achievement. 
40. $\left(0_{I}=4.47, O_{D}=5.19\right) \quad$ "Businesses will become more involved in student training through mentorships and research "fellowships.",

This event is already in the formative stages through the mentorship component of the School-To-Work initiative. Within this time frame, this event should expand to include fellowships for independent student projects which may be completed outside of the traditional school environment. This event also relates to event 38 (Curriculum, Other) which stated that "Students will have more independent study classes in which they will complete projects for credit." The students' completed projects will be assessed so they can complete the requirements of the research fellowships and receive course credit. This type of learning is also consistent with primary event 42 (Curriculum, High Impact and High Desirability) which indicated that education will become more focused on teaching problem solving, access to data bases, and the use of technology. One panelist noted that "Some (businesses) will (become involved), but most small businesses in West Virginia can't afford this."

50. $\left(\mathrm{O}_{\mathrm{I}}=4.79, \mathrm{O}_{\mathrm{D}}=5.12\right)$ "There will be an increasing emphasis on foreign language programs."

The literature on the future of the American economic system indicates that it is advisable for students to learn at least one foreign language. As the concept of the global marketplace becomes more accepted in West Virginia, educational programs will emphasize the need for students to take more foreign language courses as electives. As School-To-Work becomes more sophisticated, it might be anticipated that foreign languages may become required, not elective, courses. Distance learning (Event 14, Technology, High Impact) will facilitate the delivery of foreign language programs to areas of low student population which may not have teachers 
available. This event may also become necessary because of the rise in the Hispanic population in America.

Low Desirability Projections

There was one event which qualified in the Low Desirability category.

125. $\left(\mathrm{O}_{\mathrm{I}}=4.71, \mathrm{O}_{\mathrm{D}}=2.46\right)$ "The number of students being home-schooled will increase."

This event has been in place for several years and is anticipated to continue through this time frame. The projected increase in home-schooled students may be caused by dissatisfaction with the public schools, the idea that parents have more control over their child's education, and/or that educating at home represents a safer environment than that of the public schools. In the future, groups of parents may form educational cooperatives within communities. These cooperatives may have access to the public schools through electronic connections. The low desirability of the event is due to the potential reduction of public school student enrollment and subsequent reductions in funding afforded under the state aid formula. As one respondent stated, "What we will lose in this revolution is the intangible advantages of the old public schools which brought together kids from different socio-economic backgrounds and gave them a common experience that otherwise they would not have had. This forced experience was healthy for our democracy. It standardized our world."

\section{Other Projections}

Three primary events qualified for inclusion in this section.

38. $\left(\mathrm{O}_{\mathrm{I}}=4.77, \mathrm{O}_{\mathrm{D}}=4.67\right)$ "Students will have more independent study classes in which they will complete projects for credit." 
This event represents an increased recognition of the need for students to be able to apply knowledge and to reason, think and work independently, and for schools to emphasize individual instruction. Students will be involved in portfolio development, have increased opportunities to test out of classes by passing the Instructional Goals and Objectives, and will achieve at higher levels as their learning becomes more self-directed. The occurrence of this event will accelerate as teachers become facilitators of learning rather than deliverers of information. This event also relates to businesses becoming more involved in student training through mentorships and research "fellowships" (Event 40, Curriculum, High Desirability) and education becoming more focused on teaching problem solving, access to data bases, and the use of technology (Event 42 , Curriculum, High Impact and High Desirability).

39. $\left(\mathrm{O}_{\mathrm{I}}=4.79, \mathrm{O}_{\mathrm{D}}=4.64\right)$ "There will be an increased emphasis on school-to-work from business and industry."

Businesses want employees who work well in team situations, are adaptable to change, and are active participants in learning. The School-To-Work initiative offers students a comprehensive career development system beginning with an awareness component in grades $\mathrm{K}$ 4, exploration in grades 5-8, decision-making in grades 9 and 10, and career preparation from grades 11 through adult. This exposes students to potential career opportunities and gives them the understanding that they may be faced with changing vocations throughout their lifetime. Business and industry would support occurrence of this event as they want students to learn valuable workforce skills while in school, and have the prospect of employing the students upon graduation. This may relate to event 38 (Curriculum, Other) and the completion of projects for 
credit, the mentorships and fellowships emphasized in event 40 (Curriculum, High Desirability), and the teaching of problem solving, access to data bases, and the use of technology from event 42 (Curriculum, High Impact and High Desirability). Each of these events represents skills that business and industry actively pursue in employees. Having access to students who possess these capabilities may have long-term benefits to employers which go far beyond the implication of any of these related events. One respondent cautioned that the occurrence of this event would be undesirable if business dictates the curriculum, and noted that it could be desirable if language arts are encouraged to develop truly educated students instead of merely trained workers.

79. $\left(\mathrm{O}_{\mathrm{I}}=4.38, \mathrm{O}_{\mathrm{D}}=4.69\right)$ "There will be a continued move to the middle school concept."

This event has been occurring over the past several years and is projected to continue in this time frame. Since this event is well within the neutral impact and desirability ranges, it is assumed by the investigator that it was projected because the middle school concept is good for students. Facility and staffing needs relating to operational efficiency may also be considerations.

\section{Curriculum - Secondary Events}

High Impact and High Desirability

One secondary event qualified for inclusion in this category.

44. $\left(0_{I}=5.91, O_{D}=5.58\right) \quad$ "Programs will be developed for all 3 and/or 4 year olds."

Such programs would be designed to provide early intervention strategies to avert learning problems as students enter elementary school. Associated with these programs would be the provision of meals and other services which may be of value to families. Although such programs 
are consistent with the literature in addressing social problems, this secondary event may experience difficulty in implementation if the projected teacher shortage (Event 92, Personnel, High Impact and Low Desirability) occurs. This relates to primary event 46 (School-Community Relations, High Impact and High Desirability) which forecasted that schools would become increasingly involved in solving the problems of society.

\section{Other Projections}

One secondary event qualified for inclusion in this category.

52. $\left(\mathrm{O}_{\mathrm{I}}=4.52, \mathrm{O}_{\mathrm{D}}=4.95\right)$ "Schools will emphasize more cultural programming (art, music, theater)."

As School-To-Work has been implemented statewide and block scheduling has gained popularity, there has been concern that there would be less student participation in art, music and theater courses. Panelists, however, offered no responses to clarify their level of consensus. One consideration might be that school budgets have reduced the number of classes available because of the staffing limitations of the state aid formula. This increased emphasis will depend in changes in the state aid formula (Event 61, Finance, High Impact and High Desirability) and subsequent increases in staffing limits (Event 97, Finance, High Impact and High Desirability).

\section{Governance - Primary Events}

High Impact and High Desirability Projections

In the area of Governance, two primary events qualified in the High Impact and High Desirability category.

3. $\left(\mathrm{O}_{\mathrm{I}}=5.07, \mathrm{O}_{\mathrm{D}}=6.09\right) \quad$ "Training for school board members will become more effective." 
The high impact and even higher desirability ratings for this event are attributable to the value such training has toward improving the qualities of school board members. Some perceived the need for better training being caused by the ever-present tension between school administrators, particularly superintendents, and their elected school boards. The prevalence of individual agendas, inclinations toward special interest groups, and the number of reported ethics violations illustrate the need for more effective training. School board members themselves have expressed the need and desire for improvement in this area. One respondent stated "The question is to what degree are the knowledge and skills implemented by board mandates?" It appears to the researcher that another question might be "How many school board members would attend the training to get the knowledge and skills without the mandates?"

113. $\left(\mathrm{O}_{\mathrm{I}}=5.52, \mathrm{O}_{\mathrm{D}}=5.39\right)$ "Cross-county attendance will be routine as attendance will be determined by geographic distance, not political boundaries."

This event may occur as a matter of convenience to parents causing some loss in enrollment, particularly in smaller, more rural, counties. Schools that students attend will be determined by time in transit and geographic distance rather than county boundary lines. Greater convenience and flexibility would be provided for parents who wished to drop off their children as a school on their way to work or for those who want the educational services provided at larger facilities which may have more academic programs and extra-curricular activities. This event is currently being experimented with in several rural counties, and has been going on for quite some time in multi-county vocational centers. This event is supported by secondary event 70 which deals with the enactment of public school choice. 
High Impact Projections

Two events qualified for inclusion in the High Impact category.

6. $\left(0_{\mathrm{I}}=5.12, \mathrm{O}_{\mathrm{D}}=4.67\right) \quad$ "County school systems will be serviced regionally (transportation, nutrition services, curriculum specialists)."

This event may come as a result of multi-county agreements to deal more effectively with such issues or may relate to increased responsibilities of RESAs projected by primary event 5 (Governance, Other). Regional services may have the potential for increased savings, efficiency and effectiveness, particularly for counties that are very rural, must cross county lines to supply transportation services, would benefit from the reduced costs of regional bulk buying of various supplies, and/or cannot afford additional staff to supervise their instructional programs. Regional services would also reduce the personnel decisions and problems currently faced by county school systems. Should this event occur, the cost savings from such arrangements could circumvent any criticism about regional services representing a relinquishing of local control.

71. $\left(\mathrm{O}_{\mathrm{I}}=5.29, \mathrm{O}_{\mathrm{D}}=3.02\right)$ "Charter school legislation will be adopted in West Virginia."

Although supported by the literature, this event fell just short of qualifying as a "High Impact and Low Desirability" event. Charter schools pose a significant threat to public education because of their potential to reduce public school enrollments and subsequent revenues. The current challenge for educators is to clearly demonstrate that the public schools offer outstanding educational opportunities for students and are producing a high quality product. 
Low Desirability Projections

One event qualified as a Low Desirability event in the area of Governance.

72. $\left(\mathrm{O}_{\mathrm{I}}=4.88, \mathrm{O}_{\mathrm{D}}=2.71\right)$ "Private schools will increase in number."

This event is also consistent with the literature. Private schools, like charter schools (Event 71, High Impact), also have the capacity to reduce public school enrollments and revenues. This event could significantly reduce public school enrollments in favor of the supposed benefits of private schools. To circumvent the rise in private schools, public education needs to be able to demonstrate that it is doing a good job of educating America's young people. Unfortunately, according to the literature, private schools often lure away the best students from the public schools. One respondent stated that, should this occur, "public schools will become a haven for three classes of children - the poor, the trouble-makers, and special education students. Not many parents who care about their children will want their children in with these three population groups." If this event were to occur, there would still remain a significant number of students enrolled in public schools which could not be ignored by educators, legislators or parents. This event may also be linked to secondary event 69 regarding the emergence of the voucher system.

\section{Other Projections}

Two events qualified for inclusion in this category.

5. $\left(\mathrm{O}_{\mathrm{I}}=4.40, \mathrm{O}_{\mathrm{D}}=4.70\right) \quad$ "Services provided by Regional Education Service Agencies (RESA) will expand."

For many years RESAs have been increasing the number of services available to local county school districts. Much of this expansion has taken place because of increased 
responsibilities assigned through enactment by the Legislature, while some is the product of local initiative in response to local needs. Computer repair, bulk purchasing, regional staff development, and management of the West Virginia Education Information System (WVEIS) are examples of this ongoing event. In the future RESAs may expand their roles as facilitators for state initiatives and services. As county school systems become more dependent on technology, additional technical support will be a critical need. This event is related to event 6 (Governance, High Impact) on regional provision of services.

132. $\left(0_{I}=4.65, O_{D}=4.88\right)$ "The two boards of higher education will be eliminated."

Although this event qualified as a primary event, its impact and desirability should have little effect on public school systems. Respondents indicated that to avoid duplication of services it would be likely that, rather than the two boards (State College System of West Virginia Board of Directors and the University System of West Virginia Board of Trustees) being eliminated, they would be merged into a new board which would incorporate the functions of both original boards. One respondent indicated that there would be the possibility that a separate board for community colleges would be created.

\section{Governance - Secondary Events}

\section{High Impact and High Desirability Projections}

One secondary event qualified for inclusion in this category.

13. $\left(0_{I}=5.56, O_{D}=5.44\right)$ "There will be closure on the role of the courts in the interpretation of 'thorough and efficient' education."

This event will depend, in part, on the outcome of a projected major change in the state 
aid formula (Event 61, Finance, High Impact and High Desirability) and an increase in the staffing limits under the state aid formula (Event 97, Finance, High Impact and High Desirability).

High Impact Projections

One secondary event qualified for inclusion within this category.

70. $\left(\mathrm{O}_{\mathrm{I}}=5.90, \mathrm{O}_{\mathrm{D}}=3.61\right)$ "Public school choice will be enacted."

Many counties permit parents to select the public schools their children attend provided adequate space is available, but the practice is not statewide. The term 'enacted' refers to legislation that would be necessary for this event to occur. Occurrence of this event would correspond with cross-county attendance being considered routine (Event 113, Governance, High Impact and High Desirability).

High Impact and Low Desirability Projections

One secondary event qualified for inclusion in this category.

11. $\left(\mathrm{O}_{\mathrm{I}}=5.56, \mathrm{O}_{\mathrm{D}}=2.98\right)$ "State government will play a more prominent role in education."

Many respondents commented on what they perceived to be an increase in the "powerful political influence of the state legislature," which "will focus on a fairly narrow educational agenda - what's popular on the hustings back home. Right now it's jobs and job training." One respondent stated "It already has complete control." The West Virginia School Building Authority (WVSBA), the recent emergence of the Office of Education Performance Audits and the required submission of Unified County Improvement Plans are representative of the broadening of the state governmental function. As state centralization occurs, several 
respondents questioned what the effect might be on local county boards of education. This event may relate to primary event 34 (Curriculum, High Impact) which specified that "A state curriculum and standards will be established that will drive what is taught and tested."

\section{Facilities - Primary Events}

High Impact Projections

One primary event qualified as a High Impact event in the area of Facilities.

76. $\left(0_{\mathrm{I}}=5.45, \mathrm{O}_{\mathrm{D}}=4.73\right)$ "Facilities construction will become more and more a state function rather than a county function."

The West Virginia School Building Authority (WVSBA) emerged in 1989 as the clearinghouse for facilities construction and renovation throughout the state. County boards of education, who used to rely on general revenue sources, levies, or bond issues for construction funds, may now apply for WVSBA funding by meeting the authority's specifications. While levies and bond issues still fund a considerable amount of construction, the WVSBA has afforded all counties equal opportunity to state facility funds. Equity in funding may become more difficult to achieve in the future as the state experiences uneven population growth which will require construction in response to local needs. Counties will continue to increasingly rely on state funding as, according to the literature, fewer levies and bonds will meet with public approval. This event may also be supported by secondary events 59 ("There will be a decrease in the number of local school levies.") and 81 ("Federal government will provide funding for replacement of aging school buildings.") 
High Desirability Projections

One primary event qualified for inclusion in the High Desirability category.

83. $\left(\mathrm{O}_{\mathrm{I}}=4.62, \mathrm{O}_{\mathrm{D}}=5.05\right) \quad$ "Radon testing will be legislated for all new schools."

There is currently no requirement that new schools be tested for radon; only that certain air circulation regulations are met. The investigator has learned through informed sources that it appears possible that this legislation will be placed before the West Virginia Legislature as early as the 1999 session. Since there have been few, if any, problems linked to radon in West Virginia, the event was not considered one of high impact, and of only moderately high desirability.

\section{Other Projections}

One primary event qualified for inclusion in this category.

77. $\left(\mathrm{O}_{\mathrm{I}}=4.86, \mathrm{O}_{\mathrm{D}}=4.83\right)$ "School consolidation will continue, but will slow down."

This event, although popular enough to qualify as a primary event, was not considered by the respondents as having a high degree of impact or desirability. This may be due to the fact that much of the necessary school consolidation has already been accomplished. Some slowing in consolidation may also occur over concerns that schools may become too large. There will, however, continue to be areas with declining enrollments or inefficient economies of scale where consolidation will continue to be necessary. Construction costs applied to local levies relates to secondary event 59 which stated "There will be a decrease in the number of local school levies."

\section{Facilities - Secondary Events}

High Impact and High Desirability Projections

One secondary event qualified for inclusion in this category. 
81. $\left(\mathrm{O}_{\mathrm{I}}=5.24, \mathrm{O}_{\mathrm{D}}=5.16\right)$ "Federal government will provide funding for replacement of aging school buildings."

There were no opinions expressed by respondents to this item.

\section{High Desirability Projections}

One event, number 82, qualified for inclusion in this category.

82. $\left(\mathrm{O}_{\mathrm{I}}=4.85, \mathrm{O}_{\mathrm{D}}=5.03\right)$ "Indoor air quality will be legislated for all new schools."

Current regulations for new facilities require minimum standards for air circulation, not air quality. Panelists perceived this event to be highly desirable, perhaps because of an increase in the number of air quality problems which have occurred in the schools.

High Impact and Low Desirability Projections

One event qualified for inclusion in this category.

80. $\left(\mathrm{O}_{\mathrm{I}}=5.70, \mathrm{O}_{\mathrm{D}}=1.92\right)$ "Counties with rapidly increasing enrollments will experience financial and political problems in providing facilities and quality staff."

This event is already beginning to occur in areas where enrollments are increasing rapidly. Berkeley County has reportedly had such difficulties, particularly with facility construction. The in-migration of students is currently in excess of the county's ability to supply classrooms. The staffing issue will increase if the projected statewide teacher shortage occurs (Event 92, Personnel, High Impact and Low Desirability).

\section{Other Projections}

Two secondary events qualified in this category.

78. $\left(0_{\mathrm{I}}=4.62, \mathrm{O}_{\mathrm{D}}=3.50\right)$ "Schools will become larger." 
This event is somewhat dependent on the projected continuation of school consolidation (Event 77, Facilities, Other), or that there would be an influx of students into a given area. One respondent noted that "larger schools may be more cost effective with larger course selection," but be "less personal and student-centered." It was also pointed out that "Our largest high school is smaller than the largest one 10, 20 and 30 years ago." Another panelist stated that "As high schools become consolidated, vocational training will move into the comprehensive high school." There is growing concern among the public, however, that "bigger schools are not necessarily better schools."

85. $\left(\mathrm{O}_{\mathrm{I}}=4.88, \mathrm{O}_{\mathrm{D}}=4.79\right) \quad$ "Security systems will be installed in all public schools."

Panelists viewed this event as preventative more than necessary, accounting for its average impact and desirability ratings. School districts are considering installation of security systems to insure the safety of students and employees and to guard against theft and vandalism. Recent events which have had national exposure have raised public consciousness about school safety, and theft and vandalism are issues with which school officials are constantly faced. Security systems, like other mechanical and electronic systems, are more easily installed during new construction.

\section{Finance - Primary Events}

High Impact and High Desirability Projections

In the area of Finance, one primary event qualified in the High Impact and High Desirability category. 
61. $\left(0_{I}=5.90, O_{D}=5.60\right)$ "There will be a major revision to the school-aid formula."

The revision to the current state aid formula will become necessary to equitably distribute state funding to counties in support of a "thorough and efficient" system of education. Equity may be achieved in the future not solely on student population, but on the levels of funding necessary to have students achieve equitably. An equitable distribution will depend entirely on the kind of revisions made. One respondent noted that a new formula "may be desirable for some." This revision will possibly be the result of court action imposed on the West Virginia Legislature. Given that this may be a court issue, its resolution and ultimate implementation will probably take several years. The high impact and desirability of this event stems from the reality of the cost of a quality education system in relation to "inadequate funding from an archaic formula."

\section{Finance - Secondary Events}

High Impact and High Desirability Projections

Two events, numbers 17 and 62, qualified for inclusion in this category.

17. $\left(\mathrm{O}_{\mathrm{I}}=5.00, \mathrm{O}_{\mathrm{D}}=5.66\right) \quad$ "Federal legislation will be passed allowing for continual Erate funding."

E-rates are federal subsidies which offer discounts of 20 to 90 percent (based on free/reduced lunch applications) on telephone and Internet connections and for the acquisition of equipment necessary for the distribution of information to all classrooms. This equipment would include routers, hubs, network file servers, network wiring, data and phone lines. Software and training are excluded from E-rate funding. The high impact and desirability of this event is based on the idea that E-rate funding would be stabilized and that savings could used for other needs by school districts. 
62. $\left(\mathrm{O}_{\mathrm{I}}=5.83, \mathrm{O}_{\mathrm{D}}=2.79\right)$ "Funding for a new formula will be provided by general revenue sources, not property taxes."

Respondents indicated that tax restructuring for the new state aid formula (Event 61, Finance, High Impact and High Desirability) will be guided by the courts so that equity might be assured (Secondary Event 13). One respondent stated "The funding of public education will be restructured to equalize educational opportunities for students and equalize 'efforts' of taxpayers." Elimination of the property tax as a funding source was predicted by several panelists. One respondent noted that the current funding source is both property tax and general revenue and that "both will continue as sources, but the ratio will change."

\section{High Impact and Low Desirability Projections}

Three secondary events are listed in the High Impact and Low Desirability category.

59. $\left(\mathrm{O}_{\mathrm{I}}=5.83, \mathrm{O}_{\mathrm{D}}=2.79\right)$ "There will be a decrease in the number of local school levies."

This event may be consistent with the literature as those who currently have children in public school and support public education begin to retire. The literature indicated that once parents no longer have students in school, public education issues have a harder time being approved. Compounding this issue is the fact that West Virginia has the highest median age in the nation, with many residents living on fixed incomes. As the overall school population in the state continues to decline, levies may indeed be more difficult to pass. One respondent stated that "school levies and bonds at the local level will give way to dedicated tax streams that do not require voter approval as more and more referendums are defeated." 
67. $\left(\mathrm{O}_{\mathrm{I}}=5.24, \mathrm{O}_{\mathrm{D}}=2.53\right)$ "There will be more federal funding and more federal control."

Historically, federal funding for education has always been accompanied by regulations for its use. Regulations do not generally appear until after the funding has been authorized and questions begin to be asked about the use of the funds. As the federal government continues its involvement in addressing the social problems of America, the schools will be looked to as the social institution with the ability to solve the problems (Event 46, High Impact and High Desirability). Eventually, federal initiatives in the schools are evaluated to determine their level of effectiveness. Control will come through revisions to regulations and accountability standards by which the programs are evaluated. One respondent indicated that, while he/she expected federal funding for education to increase, the percentage of the state education budget from federal funds will remain constant.

\section{9. $\left(0_{I}=5.69,0_{D}=2.51\right) \quad$ "A voucher system of some sort will occur."}

The voucher system is a monetary incentive which allows parents the right of private school choice. This concept has been espoused by the Republican party in an attempt to answer public demands for more accountability by creating competition between the public and private educational communities. It is anticipated that vouchers will help to create an environment conducive to an increase in privatization which may occur as charter schools, university schools, neighborhood "home pods," corporate schools, or home schooling. This event is somewhat related to event 70 which deals with public school choice. 


\section{School-Community Relations - Primary Events}

High Impact and High Desirability Projections

In the area of School-Community Relations, three primary events qualified in the High Impact and High Desirability category.

46. $\left(0_{\mathrm{I}}=5.12, \mathrm{O}_{\mathrm{D}}=5.00\right)$ "Schools will increasingly become involved with other agencies in solving the problems of society."

This event is consistent with the literature and relates closely with several other primary events, all of which qualified for inclusion in the High Impact and High Desirability category. Since schools have often been looked to as the logical social agency to remedy societal problems, panelists indicated that this trend would increase in the future to the point where social service agencies would deliver services within the school. As a result, "the community will become involved in the schools and schools will go more into the community." One of the challenges that educators will face is how these services can be delivered without disrupting the instructional program. As schools come in closer contact with parents and other social agencies, facilities will be better utilized, and such programs will have an impact on how school facilities are planned.

Additional related primary events include schools serving as centers of health, social and recreational services and academic support (Event 53, School-Community Relations, High Impact and High Desirability), the expansion of after-school programs (Event 49, Curriculum, High Impact and High Desirability) and the development of comprehensive student advisement programs (Event 112, Students, High Impact and High Desirability). One secondary event, number 44, which deals with program development for all three and/or four year olds, might facilitate closer interaction between families and social service agencies when the children are of a 
young age. Secondary event 110 also projected that "Child care services will be available at the schools."

53. $\left(\mathrm{O}_{\mathrm{I}}=5.05, \mathrm{O}_{\mathrm{D}}=5.22\right)$ "Schools will serve as centers for health, social and recreational services and academic support."

Related to event 46 (School-Community Relations, High Impact and High Desirability), this event is also consistent with the literature. Educators realize that many of the social problems families deal with today have a tendency to impede student learning. Having some degree of health (including mental health) and human services available at the school would make access to these services much easier for parents who have children enrolled at the school. Educators also view this event as allowing the possibility of closer contact and communication between schools and social service agencies. Teachers and principals will work closely with parents and health and human service professionals to provide assistance to families. This would be particularly valuable should secondary event 44 occur (programs will be developed for all three and/or four year olds). Academic support and recreation may also be provided through the expansion of after-school programs (Event 49, Curriculum, High Impact and High Desirability). Should the public actively participate in these services, schools will be recognized for the role they play in the community.

118. $\left(\mathrm{O}_{\mathrm{I}}=5.83, \mathrm{O}_{\mathrm{D}}=6.33\right)$ "Parents will be taught to be educational consumers (lifelong learners) and parental involvement will increase."

This event is consistent with literature, particularly in reference to the baby-boomer generation. As this group reaches retirement age and they have more leisure time, there is expected to be an increase in educational programs which would meet their interests and 
lifestyles. Many will find time to volunteer in schools (Event 119, Personnel, High Impact and High Desirability) while others will enroll in courses in areas which are of special interest to them. This event will continue to occur as more and more adults find continued value in educational offerings even after their actual work experience is over. Parental involvement will increase as parents expect higher academic standards, well equipped buildings and facilities, and more focus on the arts. Should the public schools fail to address these issues, the public may turn toward private schools (Event 72, Governance, Low Desirability) or home schooling (Event 125, Curriculum, Low Desirability). Secondary event 9 also indicates that special interest groups may also emerge over these issues.

\section{High Desirability Projections}

One event qualified as highly desirable in the School-Community Relations area.

117. $\left(0_{I}=4.63, O_{D}=5.26\right)$ "There will be greater involvement by educators in state and local economic development."

Education has always been seen as one of the key ingredients in promoting economic development, yet educators have always been somewhat excluded from the actual process. Generally the level of involvement by educators has been limited to participation with the education committee of the local chamber of commerce. Today there is a "greater dependence on public schools to partner with business and industry and community leaders for economic revitalization of local communities and school sustainability." Given the interest that prospective businesses and industries have in obtaining a highly trained workforce, and the concerns that prospective residents have regarding the quality of the local educational system, educators should be more actively involved in local economic development. Should this event materialize, it would 
be assumed that educators would be more directly involved in the process of encouraging the relocation of business and industry as participants in the recruitment process.

\section{School-Community Relations - Secondary Events}

High Impact and High Desirability Projections

Two secondary events qualified for inclusion as being high impact and desirability events.

55. $\left(0_{\mathrm{I}}=5.67, \mathrm{O}_{\mathrm{D}}=6.24\right)$ "Closer relationships between the public schools and institutions of higher education will form to increase accessibility of public education."

The basis for this event will be the increasing number of students interested in attending college while completing high school requirements. As students begin to realize the value of dual credit programs, high schools will offer more courses and begin to serve as "transition centers to college." Technology will also allow public schools more direct access to college and university personnel, facilities, and services.

110. $\left(0_{\mathrm{I}}=5.07, \mathrm{O}_{\mathrm{D}}=5.07\right)$ "Child care services will be available at the schools."

In-school child care services will be run by professionals and will be available at a lower cost. Money collected from parents will go back to the county school system to offset the cost of this service.

High Impact and Low Desirability Projections

One secondary event qualified as being of High Impact and Low Desirability.

9. $\quad\left(\mathrm{O}_{\mathrm{I}}=5.09, \mathrm{O}_{\mathrm{D}}=2.63\right) \quad$ "Special interest groups will increase, becoming more active and more vocal." 
Special interest groups will form to impose their will on public education over a variety of issues. Special education parents seeking expanded services, the religious right objecting to values clarification, political groups attempting to control school board elections, and the public increasingly demanding accountability are examples cited by respondents of what might occur within this time frame.

\section{Technology - Primary Events}

High Impact and High Desirability Projections

In the area of Technology, one primary event qualified in the High Impact and High Desirability category.

19. $\left(0_{I}=5.56, O_{D}=5.35\right)$ "Computers will change the education structure to allow for flexible scheduling for students."

In the future there will be new uses for instructional technologies and more ways to link schools with homes, libraries, offices, workplaces, and specialized labs for instructional purposes. Through instructional modules which make use of multimedia learning components, computers will provide students with learning opportunities which are not confined to the school setting. Students will complete learning activities and assignments which they will transmit electronically upon completion. One respondent stated that in the future "they will find out that education does not require a teacher standing up in front of a class of 25 -30 students. Educational leaders will still be needed, but not at the same labor-intensive levels or working in the same manner as we do today." This will eventually lead to "mass customization" - students will be able to learn in the manner they want. Business and industry will also become involved in this process since they more and more require a computer literate workforce. The emergence of more independent study 
classes, as suggested by primary event 38 (Curriculum, Other), will enable students to complete projects for credit. Having the flexibility of working away from the traditional school environment will enable students to adjust their schedules around other activities such as work experiences. This event will have a greater impact in the upper grades and in high education. High Impact Projections

Two primary events qualified for inclusion in the High Impact category.

14. $\left(\mathrm{O}_{\mathrm{I}}=5.33, \mathrm{O}_{\mathrm{D}}=4.72\right)$ "Distance learning opportunities will increase as staff cuts occur and world-class instruction in specialized areas will be provided."

Distance learning has been used increasingly to deliver instruction in specialized and more particular areas of instruction. Distance learning meets the need to deliver classes for which an adequate number of teachers is not available or to facilitate specialized classes in various locations with a small number of students in each class. Its popularity as a means of providing equal educational opportunity for all students is expected to continue as the quality of inexpensive twoway audio and video communications improve. As the projected teacher shortage occurs (Event 92, Personnel, High Impact and Low Desirability), distance learning may be relied on to provide instruction. Distance learning provides the means for one teacher to deliver world-class instruction beyond county lines to students across the state and nation. The increased emphasis on foreign language programs (Event 50, Curriculum, High Desirability) will also cause an increase in the use of distance learning. The insignificance of the desirability level for this event may relate to the idea that distance learning reduces the direct contact that students have with teachers, and the fact that such opportunities are expensive. 
31. $\left(\mathrm{O}_{\mathrm{I}}=5.09, \mathrm{O}_{\mathrm{D}}=4.47\right)$ "Students will earn credits by taking 'official' achievement tests to demonstrate subject mastery on their computers."

This event is the logical outcome of increased use of technology. Event 19 (Technology, High Impact and High Desirability) indicated that computers would change the educational structure for students. As computer hardware and software become more sophisticated with more advanced artificial intelligence, incorrect answers could be noted and evaluated, an explanation provided for why the incorrect answer was selected, and the question corrected. As a student progresses, the computer would determine the student's ability and, when the computer and the student think the student is ready, he/she would be given the "official" achievement test to demonstrate mastery. Event 34 (Curriculum, High Impact) indicated in part, that "a state curriculum and standards will be established." Measurement of student achievement could easily be formatted for use on a computer. The computer application of achievement tests may also be a part of event 35 (Curriculum, High Desirability) which indicated that "The state assessment program will be revised."

\section{Technology - Secondary Events}

High Impact and High Desirability Projections

Three secondary events qualified as having high impact and desirability.

15. $\left(\mathrm{O}_{\mathrm{I}}=5.50, \mathrm{O}_{\mathrm{D}}=6.05\right)$ "All schools will be networked via computers."

The ever-increasing infrastructure and number of Internet connections in the schools will serve as the foundation for the occurrence of this event. Students in diverse locations will be able to work on assignments and share information electronically, expanding their capabilities and understanding of technological applications. Schools throughout West Virginia are already 
networked for administrative purposes by the West Virginia Education Information System (WVEIS).

16. $\left(\mathrm{O}_{\mathrm{I}}=5.53, \mathrm{O}_{\mathrm{D}}=5.88\right)$ "There will be computer connections between home and school."

Computer connections between home and school will allow students to receive many programs at home. This relates to event 19 (Technology, High Impact and High Desirability) which suggests that computers will allow greater flexibility in student scheduling, and to secondary event 21 concerning the availability of two-way cameras connecting students with teachers.

23. $\left(0_{I}=5.76, O_{D}=6.33\right)$ "There will be increased emphasis on the use of technology in teacher training programs."

The occurrence of this event is critical so that new teachers are adequately trained in the use of new technologies used within the classrooms. Having technology incorporated into teacher training programs will help local school districts overcome the problems they face in providing basic computer training to their employees. Teachers who have these skills will be better able to capitalize on the investments in computer technology that have been made statewide.

\section{High Impact}

One event qualified as having high impact.

32. $\left(0_{I}=5.07, O_{D}=4.76\right)$ "Speech recognition software will replace the need to have keyboarding skills."

Speech recognition software is rapidly advancing and may prove to be the primary 
interface with computers in the years ahead. As one respondent stated "A student sitting in front of a computer and talking through a headset will become a common sight, and is much more natural than using a keyboard." In educational applications, specialized software will insure the proper identification of each student is doing his/her own work.

\section{Other Projections}

One secondary event is included within this category.

$$
\begin{aligned}
& \text { 21. }\left(\mathrm{O}_{\mathrm{I}}=4.68, \mathrm{O}_{\mathrm{D}}=4.24\right) \text { "Two-way cameras will allow for interaction between } \\
& \text { teachers and students." }
\end{aligned}
$$

The use of two-way cameras have many implications for use in schools and in the home.

The technology of the not-too-distant future will allow teacher/student contact in much the same manner as distance learning (Event 14, Technology, High Impact) takes place today. Two-way cameras will be used in the teaching/learning process to provide visual contact between two persons in different locations, thus insuring that social, face-to-face contact is maintained. "The computer will change education structure and all students will no longer 'go to school' the same hours or days nor take the same courses, causing greater flexibility in scheduling (Event 19, Technology, High Impact and High Desirability)." Individualized education will become a reality and the setting may be somewhere other than a school building." One respondent stated that "Higher education will change/reform to the point that few students will live on campus" and "home technology will allow most subjects to be completed at home (particularly at the 9-12 level)." 


\section{Miscellaneous - Primary Events}

Low Desirability Projections

Two events qualified for inclusion in the Low Desirability category.

63. $\left(\mathrm{O}_{\mathrm{I}}=4.26, \mathrm{O}_{\mathrm{D}}=2.56\right) \quad$ "Advertising in the schools and sponsorship of athletic teams will begin."

Although this event qualified as a primary event with an average impact level, it was not considered desirable. It would appear that the panelists felt that advertising in the schools and sponsorship of athletic teams might lead to an increase in the undue influence of the advertiser and a potential loss of control by the school. Advertising and sponsorship would supply revenue and increase the amount of funds available, but might diminish the role of the parents who support school programs through booster organizations. Without the need for additional funding, parents would become less involved, particularly at the high school level when parent/student/school involvement is harder to maintain. Some parents who actively support local school activities might feel that they were actually giving up some degree of control and would lose the camaraderie with other parents.

124. $\left(0_{I}=3.80, O_{D}=2.66\right)$ "Home school students will be allowed to participate on high school athletic teams.

The low desirability of this event may emanate from the general feeling that, if home school students were to desire to participate on high school athletic teams, they should also participate in the daily academic program of the school. There appears to be little desire to extend the capability to participate to persons who reject the concept of public school education and its associated activities. From the parents' perspective, however, they may feel that they can 
provide a better academic program for their children, but still desire that those children have socialization that is provided through after-school activities such as athletics. As a primary event, panelists clearly indicated that this event will occur, but it may be precipitated by some form of legal action. One respondent suggested that occurrence of this event will "eventually lead to club sports, rather than school sports."

\section{Miscellaneous - Secondary Events}

High Impact and High Desirability Projections

One secondary event qualified for inclusion in this category.

127. $\left(\mathrm{O}_{\mathrm{I}}=5.93, \mathrm{O}_{\mathrm{D}}=6.74\right) \quad$ "The standard of living in West Virginia will improve."

The standard of living will improve when the state experiences significant economic development and a reduction in the number of unemployed. One respondent suggested that this might take place through "job sharing."

\section{Long-Term Time Frame, 2011-2020}

There were no primary events which qualified for inclusion within this time frame.

\section{Students - Secondary Events}

High Impact Projections

121. $\left(\mathrm{O}_{\mathrm{I}}=5.36, \mathrm{O}_{\mathrm{D}}=4.82\right) \quad$ "All students will have IEPs (Individualized Education Plans).”

The current "five-year plans" are forerunners of IEPs which would evaluate each student's achievement, skills and trades. This event would also indicate that IEPs would be developed for each student at each grade level. Students would proceed through their specially designed 
learning plans, be allowed to master each component according to their own learning styles, and given the responsibility to achieve at their own pace. IEPs would also require periodic review and revision. Increased performance assessment of students including test scores, skills, and trades (Event 36, Students, High Impact and High Desirability) would require more time for teachers during the day. This event may be accompanied by schools becoming year round in most or all counties (Secondary Event 107).

\section{Personnel - Secondary Events}

High Desirability Projections

43. $\left(\mathrm{O}_{\mathrm{I}}=5.19, \mathrm{O}_{\mathrm{D}}=4.51\right)$ "All teacher training programs will take five years to complete."

The intent of five year teacher training programs is to provide the student with a high quality, comprehensive program and a Master's degree upon graduation. This contradicts consensus on reductions in teacher certification requirements during a teacher shortage (Event 93, Personnel, High Impact and High Desirability). At odds here is the need to produce more teachers in a shorter time as opposed to a longer teacher education program. It may also be anticipated that teacher education programs will come under greater scrutiny and criticism as they move toward the creation of five-year programs, but "they will also improve as a result."

\section{Curriculum - Secondary Events}

High Impact and High Desirability Projections

107. $\left(0_{\mathrm{I}}=5.60, \mathrm{O}_{\mathrm{D}}=5.05\right) \quad$ "Schools will become year round in most or all counties."

Year-round school may manifest itself in various ways as schools become centers for 
learning as opposed to a group of classrooms situated under a common roof. The extra days would allow students to attend on a rotating basis, with extra time (which may be optional) used for remediation and recreational activities. One respondent stated "Remediation will shift from an in-school function to an after-school, home and extended year function." As schools become more involved with other social service agencies, the need to extend the school year may be necessary so that delivery of those services will not lose continuity. Some of the extended time during the school year may also be used by teachers for staff development (Event 65, Personnel, High Impact and High Desirability). As adults become life-long learners, and/or are forced to change jobs or careers, schools will be utilized as year-round retraining sites. Year-round schools will also be dependent on the installation of air conditioning (Secondary Event 84). One respondent noted that "this would be one of the best things we could do, if only it wasn't so hard to get people to accept change." In order for this event to become a reality, additional revenues would have to be generated to fund teacher salaries in year-round or extended year situations.

122. $\left(0_{I}=5.69, O_{D}=5.78\right)$ "The statewide college-going rate will exceed 66 percent."

Panelists indicated that this may rise to about the level specified among graduates, "but most of the increase will be in one-year and two-year certificate and associate degree programs." It was suggested that a rise in the college-going rate may be facilitated through more cooperation between the West Virginia Board of Education and the higher education boards.

High Desirability Projections

20. $\left(0_{I}=5.69, O_{D}=4.83\right) \quad$ "Much of the school time of children will be spent in places other than a traditional school building (e.g., home, library, 
offices, workplaces, specialized labs)."

This event applies primarily to secondary students and will be facilitated by the workbased learning component of SB 300, and on the availability of the necessary technology to support learning in locations other than traditional schools. Students may spend a portion of their day at home working on assignments or projects, attend a learning/media center for collaboration with other students, and fax or e-mail their work to the school for review and feedback from the teacher. Since students would be in school on a rotating basis, the same facility could actually serve many more students. Among others, this event relates directly to event 19 (Technology, High Impact and High Desirability) which stated "Computers will change the education structure to allow for flexible scheduling for students."

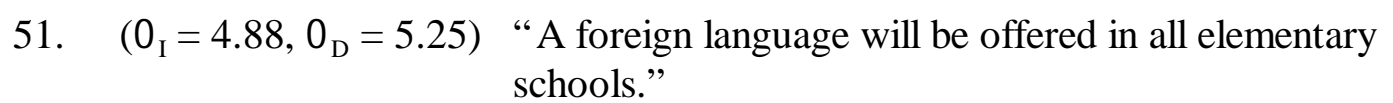

This relates to primary event 50 (Curriculum, High Desirability) which specified that there would be an increasing emphasis placed on foreign language programs. The need to learn a foreign language will become so essential in the global marketplace that programs will begin in the elementary schools.

\section{Governance - Secondary Events}

High Impact and High Desirability Projections

7. $\left(0_{I}=5.44, O_{D}=5.00\right) \quad$ "Services (transportation, food services, maintenance) will be contracted."

This may occur through contracting with private providers or with RESAs. The high 
impact and desirability of this event may be attributable to the potential savings through competitive bidding and bulk purchasing, a reduction in staffing limitations under the current state aid formula, and the avoidance of labor disputes with personnel in these service areas.

\section{Facilities - Secondary Events}

High Impact and High Desirability Projections

84. $\quad\left(0_{\mathrm{I}}=5.18, \mathrm{O}_{\mathrm{D}}=5.93\right)$ "Every school will be air conditioned."

This would cost a tremendous amount of money which will delay the occurrence of this event until this time frame. Occurrence of this event is necessary to support year-round schooling (Secondary Event 107) which is also predicted to occur during this time frame.

\section{Finance - Secondary Events}

High Impact Projections

57. $\left(\mathrm{O}_{\mathrm{I}}=5.63, \mathrm{O}_{\mathrm{D}}=4.70\right)$ "The funding of education will become the responsibility of the state with little or no local discretionary funding."

This event may occur in reaction to the need for a statewide excess levy or be a part of the resolution of the "thorough and efficient" issue. One respondent indicated that eventually there would be a "state-level data management system that enables the WV Legislature to micro manage budgets of local school districts."

68. $\left(\mathrm{O}_{\mathrm{I}}=5.78, \mathrm{O}_{\mathrm{D}}=1.88\right)$ "Funding for education will be diverted to meet the health care needs of the elderly."

This is consistent with the literature, and is the result of an increasingly older population. One respondent noted that this diversion of funds would not cause a reduction for education, but 
funding for the elderly will rise. Even though education funding may not be reduced, it cannot be expected to increase with additional funding being appropriated for health care for the elderly.

\section{Technology - Secondary Events}

Other Projections

26. $\left(0_{\mathrm{I}}=4.80, \mathrm{O}_{\mathrm{D}}=3.81\right)$ "Hard copy, paper textbooks will be replaced by electronic texts."

The likelihood of this event occurring will increase as technology advances. Books will be cheaper to purchase, store, and transport when they are condensed to a CD ROM and accessed

from a computer screen. Although panelists thought that this may occur, they indicated that some texts would remain necessary.

86. $\left(\mathrm{O}_{\mathrm{I}}=4.30, \mathrm{O}_{\mathrm{D}}=4.91\right)$ "There will be a phone on every teacher's desk."

Several respondents indicated that it would be more likely that there will be a computer on every teacher's desk that will also serve as a communication device. Cell phones represent another possibility. One respondent cautioned that this event must be regulated to avoid abuses such as "chatting."

\section{Miscellaneous - Secondary Events}

High Impact and High Desirability Projections

66. $\left(\mathrm{O}_{\mathrm{I}}=5.40, \mathrm{O}_{\mathrm{D}}=5.15\right)$ "A national/universal health care program will be established."

Although this event met the criteria for inclusion as a High Impact and High Desirability secondary event, there were no comments made by the respondents other than to suggest that it 
would occur.

126. $\left(\mathrm{O}_{\mathrm{I}}=6.10, \mathrm{O}_{\mathrm{D}}=6.75\right)$ "West Virginia will experience significant economic growth."

Significant economic growth will be caused by "structured changes in the economy globalization, greater diversification in the West Virginia economy, technology, and information based." Occurrence of this event would be the precursor to event 127 ("The standard of living in West Virginia will improve). Interestingly, the panelists chose economic growth to follow an increase in the standard of living (2001-2010 time frame).

\section{After 2020 Time Frame}

There were no primary events which qualified for inclusion within this time frame.

\section{Technology - Secondary Events}

Other Projections

30. $\left(\mathrm{O}_{\mathrm{I}}=3.90, \mathrm{O}_{\mathrm{D}}=3.14\right)$ "Teacher avatars (computerized embodiments of another person - a sports figure, celebrity, etc.) will allow students to choose and interact with the person they are most comfortable learning from."

This is a sophisticated use of technology which can individualize instruction and provide feedback that a teacher of a class of thirty students cannot. The use of this technology would further customize the process of learning to the student's needs. 


\section{Never Time Frame}

\section{Miscellaneous - Primary Events}

There were no primary events included in the High Impact and High Desirability, High

Impact, High Desirability, High Impact and Low Desirability, and Low Desirability categories.

Other Projections

Only one primary event qualified as a primary event for inclusion in this time frame.

120. $\left(\mathrm{O}_{\mathrm{I}}=3.72, \mathrm{O}_{\mathrm{D}}=3.50\right)$ "Prayer will return to the public schools."

Although this event qualified as a primary event, it did not qualify as having any significant degree of impact or desirability. At present, students are permitted to pray in school, but cannot be required to do so as a school function. Respondents indicated that this was a Constitutional issue which would never change. There may be some effort from the religious right to return prayer to the classroom, especially if recent news events continue. Interestingly, the less than average impact and desirability ratings would indicate that this event could not even be considered an admirable idea, but will remain a "dead issue."

\section{Personnel - Secondary Events}

High Impact and Low Desirability Projections

105. $\left(\mathrm{O}_{\mathrm{I}}=5.61, \mathrm{O}_{\mathrm{D}}=2.42\right) \quad$ "Collective bargaining will be enacted."

Collective bargaining, long a popular issue with professional teachers' organizations, is not predicted to occur in West Virginia. There were no comments received from panelists regarding 
this event.

\section{Curriculum - Secondary Events}

High Impact and Low Desirability Projections

75. $\left(\mathrm{O}_{\mathrm{I}}=5.50, \mathrm{O}_{\mathrm{D}}=2.47\right)$ "The state will audit and continue to set standards, but the private sector will deliver the services (through computer assisted instruction)."

This event is based on the idea that educational services will be delivered more and more through technology. Specialized software will continue to flood the marketplace and will be available to meet the learning needs of all types of students. Several panelists indicated, however, that society would never tolerate this type of educational environment, opting instead for real people to deliver instruction and interact with the students.

\section{Governance - Secondary Events}

High Desirability Projections

12. $\left(\mathrm{O}_{\mathrm{I}}=6.41, \mathrm{O}_{\mathrm{D}}=4.31\right)$ "The Legislature will deregulate education."

This event, although having the potential of highly desirability for the panelists, was considered to be inconsistent with another event which is projected to occur. Event 11 (Governance, High Impact and Low Desirability) predicted to occur in the 2001-2010 time frame, specified that "State government will play a more prominent role in education."

\section{Low Desirability Projections}

1. $\left(\mathrm{O}_{\mathrm{I}}=3.28, \mathrm{O}_{\mathrm{D}}=2.20\right) \quad$ "Local county boards of education (with five members) will be replaced by seven or nine-member boards."

All suggested events dealing with changes in the structure of county boards of education 
were rejected.

2. $\left(\mathrm{O}_{\mathrm{I}}=3.51, \mathrm{O}_{\mathrm{D}}=2.80\right) \quad$ "There will be non-partisan primary and general election of local school boards."

Since no comments were received from the panelists regarding this event, the investigator assumes that having both a primary and general election of school board members was considered unnecessary.

Other Projections

10. $\left(\mathrm{O}_{\mathrm{I}}=4.57, \mathrm{O}_{\mathrm{D}}=3.67\right)$ "School-based governance will erode the authority of local school boards."

Panelists generally viewed school-based governance positively, but did not foresee any erosion of the authority of local schools boards. The local school boards themselves will not relinquish control of education to schools, except in matters of minor importance.

\section{Finance - Secondary Events}

High Impact and High Desirability Projections

64. $\left(\mathrm{O}_{\mathrm{I}}=5.20, \mathrm{O}_{\mathrm{D}}=5.73\right)$ "Teacher salaries in West Virginia will rise above the national average."

This event would have to be predicated on secondary event 126 (West Virginia will experience significant economic growth) and would be related to an increase in the standard of living (Event 127, Miscellaneous, High Impact and High Desirability). As the economy in West Virginia rises, so too will the economies of other states. In order to have sufficient funds available to pay West Virginia teachers at or above the national average, the West Virginia economy would 
have to rise at a faster rate than other states, or more funding would have to be allocated to education by the legislature. It can be expected, however, that more demands on public school teachers will continue to push salaries higher. One respondent pointed out that, when allowing for the cost of living, West Virginia teacher salaries meet the national average.

101. $\left(0_{\mathrm{I}}=5.16, \mathrm{O}_{\mathrm{D}}=4.32\right) \quad$ "The Rule of 80 will be passed by the Legislature."

This event is unlikely to occur simply because of the impending teacher shortage. Having current employees opting for early retirement would open jobs in the face of a teacher shortage (Event 92, Personnel, High Impact and Low Desirability).

\section{Technology - Secondary Events}

Other Projections

27. $\left(0_{I}=4.76, O_{D}=3.63\right)$ "The emphasis on computer skills will diminish when it is realized that computers are simply tools for well-prepared educators to use and they do not teach students to think, read, write, appreciate the arts, challenge and improvise."

Panelists rejected the notion that the emphasis on computer skills will diminish. It must be realized that, although there are limitations to technology, it will become more and more a part of life in the future.

\section{Miscellaneous - Secondary Events}

\section{Other Projections}

73. $\left(\mathrm{O}_{\mathrm{I}}=4.90, \mathrm{O}_{\mathrm{D}}=4.44\right)$ "Private schools will not be able to select or discriminate among students."

This event was rejected from occurring because, in the opinion of the investigator, the 
notion of not being able to select students is in violation with one of the reasons that private schools exist: often to serve a specialized group of students.

\section{Scenario Summary}

The scenario was organized chronologically and included the following time frames: 20012010, 2011-2020, After 2020, and Never. There were no events in the 1999-2000 time frame. Within each time frame, events were presented according to topical areas which included Students, Personnel, Curriculum, Governance, Facilities, Finance, School-Community Relations, Technology, and Miscellaneous. Both primary and secondary events were included within each area.

Review of the events within the time frames enabled the identification of seven trends which should be of significant importance to educational leaders and planners. Development of each of these trends will span several time frames, and will be presented accordingly.

The first trend that will affect the future of public education in West Virginia is that accountability and expectations for student achievement and behavior will increase. This new accountability will not limit itself to students, but will extend throughout the school systems to teachers, administrators and school boards.

In the 2001-2010 time frame, greater emphasis will be placed on students to achieve at higher levels and to accept responsibility for their behavior. To provide students with support to meet these expectations, student assistance programs will gain acceptance and offer a wide variety of services. As schools respond to the national concerns about academics and discipline, the state will play an increasingly important role in guiding the future of public education. Based on the 
current Instructional Goals and Objectives (IGOs), a statewide curriculum will emerge, and there will be more emphasis on assessment of student achievement. The state-county testing program will be revised so that there will be greater alignment and congruence between what is taught and what is tested. Emphasis will also be placed on what students can actually do upon graduation. High school graduation requirements will increase and there will be more emphasis on foreign language programs.

Interest in assessment may lead to the enactment of competency testing for teachers and administrators. Concerns about teacher quality will also refocus attention on the intent of current West Virginia school law that preference be based on qualifications rather than seniority.

The public schools will begin to develop programs for three and four year-olds, the middle school concept will continue to increase in use, and there will be a resurgence in the importance and amount of cultural programming (art, music, theater) available to students. The number of independent study classes in which students will complete projects for credit will increase. Business and industry will also become more involved with public education through their participation in the School-to-Work initiative by offering more mentorships and fellowships.

Concerns about the deteriorating level of student behavior and increasing need for safety in schools may lead to some national effort to return civility to the public schools. As the public insists on safer schools, there will be an increased need for, and number of, alternative programs to remove troublemakers from the regular classrooms. These concerns will also lead to an increase in the number of parents who send their children to private schools or opt to homeschool them. School choice will likely be enacted statewide, giving parents the right to select the schools their children will attend. Cross-county attendance will become commonplace. It is 
possible that special education laws might be relaxed to facilitate the enactment of disciplinary measures for these students.

Special interest groups are expected to increase in number and become more active and vocal. School boards will be held to higher standards and will be more critically evaluated by the public. In response, training for school board members will become more effective. New ways will be sought to operate school systems more economically and efficiently. Efforts to economize may lead to the emergence of regional services for transportation and nutrition programs. Regional Education Service Agencies (RESAs) will expand their services, particularly by providing curriculum specialists to counties. The state's desire to reduce inefficiency by avoiding duplication of services will also lead to the elimination of the two boards of higher education and the emergence of a new governing body, perhaps by merger of the original two.

During the 2011-2020 time frame, the continued emphasis on student performance will lead to all students having Individual Education Plans (IEPs) throughout their school years. Through advances in technology and increased interest in applied work-related skills, students will spend much of their school time in places other than a traditional school building. Schools will also become year-round in most or all West Virginia counties. In response to the increasing need for students to know at least one foreign language to participate in the global marketplace, foreign language programs will be offered in all elementary schools. Ultimately, the college going rate for West Virginia high school graduates could reach 66 percent.

As public schools experience these changes, teachers will need to be highly trained, versatile, facilitators of learning. It is expected that most or all of the teacher education programs in West Virginia will be five-year programs which will provide students with the skills necessary 
to assume teaching responsibilities that can only be speculated about today.

There was general agreement that the state will continue to set standards and audit the performance of county school systems, but that ultimate responsibility for the delivery of instruction would never be taken from the teachers in favor of services provided by the private sector through computer-assisted instruction. While technology can be expected to deliver quality educational programming, it is expected that technology will only facilitate learning, and not replace the human contact between teacher and student.

The second trend identified from the scenario is that schools will play an increasing role in the resolution of the problems of society. After-school programs will expand to provide academic support and recreation to students. These programs will be of particular value to working parents and to students who require or desire additional academic assistance. Schools will also become centers for the delivery of other social services and will become increasingly involved with other agencies to provide health, social and recreational services. Child care services for employees and teen parents will also increase in number. The middle school concept will expand throughout West Virginia to better meet the needs of middle childhood-aged students. Schools will also become centers of learning as more adults become lifelong learners.

Third, the projected teacher shortage will impact certification and staffing patterns. Although the shortage is a low desirability event, the profession of teaching will be more valued because of it. Certification requirements may have to be reduced in certain subject areas as the shortage accelerates, and there may be some flexibility added to the process to provide for interstate and international certification. Some relaxation of restrictions of the state retirement system may encourage some retirees to return to teaching. Depending on its severity, the 
shortage may cause county school systems to contract with retirees to teach one or two classes per day. An increasing number of retirees are expected to serve as volunteers within the schools.

It is also projected that the shortage will be proportionately greater among administrators than teachers. The creation of additional administrative opportunities will increase the number of females in administrative positions. An increase in the number of administrative retirements may cause a gap in the quality of leadership, due mainly to the lack of experience of new administrators.

The continued out-migration of students projected until 2010 will offset the statewide teacher shortage somewhat. Should the shortage be greater than expected and the supply fail to meet demand, there will be a distinct possibility that teachers without certification may be recruited from the private sector.

Fourth, public education will experience increasing competition from the private sector. The number of private schools will increase which will divert students from the public schools. Fueling this movement will be issues such as poor academic performance, unabated discipline problems, and school safety. The voucher system, likely to be enacted before 2010, will accelerate the migration from public to private schools.

The same effect will be caused by an increasing number of home schooled students. Participation by these students on high school athletic teams is projected.

Charter school legislation will be enacted opening new avenues for privatization and the operation of charter schools will be available to the public school systems.

The selection process used to discriminate among applicants for private school is projected never to change. 
The fifth trend is that technology will play an increasing role in the education process. The impact of technology will extend from the delivery of curriculum and test taking to increased educational opportunities through distance learning. The proliferation of technology will permit many learning activities to occur outside of the traditional school environment. Computers will change the educational system to allow for flexible scheduling for students. Students will be able to earn credits by taking 'official' achievement tests to demonstrate subject mastery on their computers. The use of distance learning will increase, providing world-class instruction in specialized areas and helping alleviate the projected teacher shortage. Teachers will be better trained in technological applications through their teacher education programs, many of which will be five-year programs.

Technology will not only support and enhance the delivery of curriculum, but will, along with problem solving and access to data bases, become an educational focus.

Other events likely to occur between 2001 and 2010 include the networking of all schools by computer for curricular use, computer connections between home and school, and the use of two-way cameras to allow for interaction between teacher and student in different locations. It is also projected that voice recognition software will become sophisticated enough to virtually eliminate the need for keyboarding skills.

Between 2011 and 2020, hard copy, paper textbooks will be replaced by electronic texts. These electronic texts will be stored on small, portable, computer notebooks. Each teacher's desk will be outfitted with a telephone, computer or other type of communication device which would not only serve as a safety precaution, but as a means of communicating with students who are working on independent projects in other locations. 
After 2020, computer software will reach a level of sophistication that will enable the use of avatars in the teaching/learning process. Avatars will be teaching resources only, and will never replace the classroom teacher in the delivery of instruction.

One aspect of technology predicted never to occur was that emphasis on computer skills will diminish once educators discover that they do not teach students to think, read, write, appreciate the arts, challenge, and improvise.

Sixth, new systems of financing public education will be developed. Between 2001 and 2010, there will be a major revision to the state aid formula. Schools will be funded more from general revenue sources, not property taxes. As part of the formula revision, staffing limitations for professional and service employees will be increased above current levels. Additional funding will be available to provide extra paid days for teacher staff development. Advertising and the sponsorship of athletic teams at the school level will also begin during this time.

Other events that may occur within this time frame include closure of the role of the courts in the interpretation of 'thorough and efficient' education as the state continues to implement its accountability system and a decrease in the number of school levies approved by the voters. The federal government is expected to pass E-rate legislation, but this increase in federal funding may ultimately lead to more federal control.

Between 2011 and 2020, county school systems will contract for transportation, nutrition and maintenance services. Such contracting would represent significant cost savings to county school systems, but would reduce the earnings of employees involved in the delivery of these services. The need to reduce expenditures by contracting may, in part, be caused by stagnation in the amount of funding for education while expenditures for the health care needs of the elderly 
rapidly increase. During this time frame, funding for education will become the responsibility of the state with little or no local discretionary funding.

Several finance related items will never occur including collective bargaining, the rule of 80, and a rise in West Virginia teachers' salaries above the national average.

Last, there will continue to be a major emphasis on improving and replacing school facilities throughout West Virginia. During the 2001-2010 time frame, counties with increasing student enrollments will continue to experience financial and political problems in providing facilities. Facility construction will become more a state than local function, and the federal government will begin to provide funding for the replacement of aging school buildings. Consolidation, often the cause of new facility construction, will continue, but will slow down. With additional consolidation, schools in West Virginia will become larger. Radon and indoor air quality testing will be legislated for all new schools. Security systems will be installed in all West Virginia public schools.

Between 2011 and 2020, every West Virginia school will be air conditioned. This will enable schools to plan for extended or all year programming.

In addition to the events associated with the seven identified trends, other events were identified that must be included in the scenario. During the 2001-2010 time frame, parents and community members will increasingly become life-long learners, and parental involvement will increase. Educators will become more involved in local economic development.

Between 2011 and 2020, a national/universal health care program will be established, and West Virginia will experience a period of significant economic growth.

There were several events that were projected never to occur. These included the return 
of prayer to the public schools, the deregulation of education by the legislature, a change in the number of county board of education members, deterioration of county board of education authority due to site-based management, and changes in the election process for local school boards.

\section{Summary}

The purpose of this study was to apply the Delphi method of forecasting to the future of public education in West Virginia and to develop a scenario detailing the time, impact, and desirability of selected events generated by an expert panel.

\section{Collection of the Data}

The data collection phase of this study consisted of three rounds which began on September 18 and ended on November 15, 1998. The Round 1 questionnaire was mailed to all forty-seven panel members. Forty-two of the forty-seven panel members responded from which one hundred thirty-four events were generated.

Round 2 was mailed to all forty-seven panel members on October 7, 1998. Forty-three panelists responded in Round 2. On October 26, 1998, the Round 3 questionnaire was mailed to the forty-three panel members who responded in Round 2. The final total return for Round 3 was

forty-two of forty-three panel members. A total of thirty-nine of the forty-seven panel members responded to all three rounds of the Delphi, or 83.0 percent. 


\section{Treatment of the Data}

Upon receipt of the forty-three Round 2 questionnaires, the investigator calculated the median time frame and the mean impact and desirability ratings for each event. Time frames based on median group responses for each event were returned to the forty-three Round 2 respondents in Round 3. Respondents were asked to reassess each of their time frame predictions which differed from the median group response and were offered the opportunity to change their responses, or let them remain the same. Panelists were asked to provide a reason for their time frame projection only if it differed from the consensus of the group. The data was presented by time frame with dissenting opinions in Chapter 4.

\section{Conclusions}

The following conclusions, given the limitations of this study, seem warranted.

1. The Delphi technique proved to be an appropriate and effective method for forecasting the future of public education in West Virginia.

The topic produced levels of response that were unusually high in all three rounds of the Delphi. Enthusiasm and interest in projecting future events were due to the personal relationship of each respondent's professional position and West Virginia public education.

The responses from the panelists facilitated the arrangement of events into topical areas. Each of these areas was used to develop the scenario.

2. The research methods and procedures used in this Delphi study were effective in obtaining information with which to frame the scenario. The forty-seven panelists were representative of virtually every professional and service education and education-related agency, 
organization or constituency in West Virginia. Information obtained from this broad-based group was both representative and complete.

The Delphi used forced-choice time frames which were developed into median estimates of occurrence, and mean impact and desirability ratings provided for procedural consistency during data collections and analysis.

The scenario was designed to provide an overview of all qualifying events by topical area, time frame and level of impact and desirability which could be used as a basis for educational planning and decision-making.

The Delphi and the scenario proved to be an excellent research procedure in obtaining, organizing, and presenting information, and as a resource for continued planning efforts.

3. The information generated by the study would indicate that a number of events will occur, particularly within the 2001-2010 time frame, that will affect public education in West Virginia.

Through examination of these events, the following seven trends emerged. Students will be held more accountable for their academic performance and their behavior. Schools will have an increasing role in solving the problems of society. A projected teacher shortage will impact staffing patterns and certification requirements. Public education will experience increasing competition from the private sector as private schools and parents doing home schooling increase. Technology will play an increasing role in public education through distance learning, alternative learning environments, and availability of data. New systems of funding public schools will be developed, and there will continue to be a major emphasis on improving and replacing school facilities throughout West Virginia. 
4. Consistent with these trends, much of what will impact education will occur from outside the educational framework. The current concern with the improvement of achievement and behavior, societal problems, changing demographics due to an aging population, outside competition, a legislative change in the way school systems are funded, and advancements in technology will cause a reaction within and by the public education community. Through an awareness of these trends and their corresponding events, educational leaders and planners will be better prepared to anticipate the future. Through increased collaboration, cooperation, and coordination, educational leaders may devise strategies to deal with the future so that students continue to be the beneficiaries of quality in West Virginia public education.

\section{Recommendations}

Several recommendations are suggested based on the outcome of this study:

1. That educators carefully consider the topical areas outlined, as well as the corresponding events contained therein. The actual impact and desirability of these events may differ from district to district, particularly in the areas of social services, finance, competition, and the projected teacher shortage.

2. That a follow-up study be conducted after ten years to determine the reliability and validity of the projections contained in this study. Such a study would also extend the time frames and create a new scenario for the future.

3. That a follow-up study be conducted to identify any contingencies that might change the date, impact or desirability of the events identified in this study.

4. That a similar study be conducted on a national level which would generate projections 
from educational leaders in other geographic areas.

5. That a similar study be conducted using teachers in various subject areas in West

Virginia. Results of such a study could be compared and contrasted to the results of this study and provide information on projected changes in curriculum.

6. That this study be replicated so that the categories (Students, Personnel, Curriculum, Governance, Facilities, Finance, School-Community Relations, Technology, and Miscellaneous) could be re-analyzed using new panels of experts who specialize in these particular areas. 


\section{WORKS CITED}

Archer, Jeff. 1998. "NYC Voucher Students Post Modest Gains.” Education Week, vol. xviii, no. 10, (November 4). Bethesda, Education Week.

Arisman, Susan. 1994. "From Active Teaching to Active Learning," in Educational Innovation: An Agenda to Frame the Future, Charles E. Greenawalt, II, ed. New York: University Press of America.

Arons, Steven. 1994. "The Threat to Freedom in Goals 2000," in The Future of Education: Perspectives on National Standards in America, Nina Cobb, ed. New York: College Entrance Examination Board.

Ascher, Carol, Norm Fruchter and Robert Berne. 1996. Hard Lessons, Public Schools and Privatization. New York: The Twentieth Century Fund Press.

Bacal, Eva K. 1987. “On Being A School Board Member,” in American School Boards: The Positive Power. Arlington: National School Boards Association.

Barber, Larry W., ed. 1996. Straight Talk About America's Public Schools: Dispelling the Myths. Bloomington: Phi Delta Kappa.

Bennett, William J. 1988. American Education, Making It Work. Washington: United States Department of Education.

Bennis, Warren. 1989. On Becoming A Leader. Reading, MA: Addison Wesley.

Berliner, David C., and Bruce J. Biddle. 1996. The Manufactured Crisis - Myths, Fraud, and the Attack on America's Public Schools. Reading, MA: Addison-Wesley.

Bloomfield, Masse. 1995. The Automated Society; What the Future Will Be and How We Will Get It That Way. Canoga Park: Masefield Books.

Boschee, F., Uhl, P. L., and J. A. Bonaiuto. 1993. "Barriers to Site-Based Management and Shared Decision Making, as Perceived by School Board Presidents and School Administrators," ERS Spectrum, vol. 11, no. 1. 
Bracey, Gerald W. 1993. "The Third Bracey Report on The Condition of Public Education." Phi Delta Kappan, vol. 75, no. 2, (October). Bloomington: Phi Delta Kappa.

1996. "What Happened to America's Public Schools?: Not What You May Think," in Straight Talk About America's Public Schools: Dispelling the Myths, Larry W. Barber, ed. Bloomington: Phi Delta Kappa.

1996. “Why Can't They Be Like We Were?, in Straight Talk About America's Public Schools: Dispelling the Myths. Larry W. Barber, ed. Bloomington: Phi Delta Kappa.

Bradley, Ann. 1998. "New Teachers Are Hot Commodity." Education Week, vol. XVIII, no. 1, (September 9). Bethesda: Education Week.

Bureau of Business Research. 1992. North Central West Virginia Economic Impact Analysis: Supply and Demand Inventory. Morgantown: West Virginia University.

Bureau of Business and Economic Research. 1997. County Data Profile 1997-1998 - United States. Morgantown: West Virginia University.

1997. County Data Profile 1997-1998 - West Virginia. Morgantown: West Virginia University.

Center for Economic Research. 1992. West Virginia 1990 Census Profile Series. Morgantown: West Virginia University.

1992. State of the Region Today and 2000. Morgantown, West Virginia University.

Center on National Education Policy. 1996. Do We Still Need Public Schools? Bloomington: Phi Delta Kappa.

Cetron, Marvin J., and Marcia Appel. 1984. Jobs of the Future, The 500 Best Jobs - Where They'll Be and How To Get Them. New York: McGraw-Hill.

Cetron, Marvin J., and Owen Davies. 1989. American Renaissance, Our Life at the Turn of the 21st Century. New York: St. Martin's Press.

Cetron, Marvin J., and Margaret Gayle. 1991. Educational Renaissance, Our Schools at the Turn of the Twenty-First Century. New York: St. Martin's Press.

Chubb, John E., and Terry M. Moe. 1990. Politics, Markets \& America's Schools. Washington: The Brookings Institution. 
Clinton, Bill. 1990. "Schools Must Be Restructured," in America's Future: Opposing Viewpoints, William Dudley and Bonnie Szumski, eds. San Diego: Greenhaven Press.

Cobb, Nina, ed. 1994. The Future of Education: Perspectives on National Standards in America. New York: College Entrance Examination Board.

Coleman, Randy. 1998. “Consolidation Foes Say Bigger Isn't Better.” Clarksburg ExponentTelegram, vol. 72, no. 47, (August 23). Clarksburg, WV: Clarksburg Publishing Co.

Cross, Christopher T. 1994. "Implications of Subject-Matter Standards," in The Future of Education: Perspectives on National Standards in America, Nina Cobb, ed. New York: College Entrance Examination Board.

DeCrane, Alfred C., Jr. 1996. “A Constitutional Model of Leadership," in The Leader of the Future, by Frances Hesselbein, Marshall Goldsmith and Richard Beckhard. San Francisco: Jossey-Bass.

DePree, Max. 1989. Leadership is an Art. New York: Dell Publishing.

Dudley, William, and Bonnie Szumski, eds. 1990. America's Future: Opposing Viewpoints. San Diego: Greenhaven Press.

Dulaney, Jack C. 1980. “The Impact of Future-Oriented Information on Predicting Curricular Needs in Public Schools." Morgantown: West Virginia University. First Search, Dissertation Abstracts Online, Accession No. AAG8029271.

Dychtwald, Ken, and Joe Flower. 1989. Age Wave, The Challenges and Opportunities of an Aging America. Los Angeles: Jeremy P. Tarcher, Inc.

Education Week. 1998. “Quality Counts ‘98,” vol. XVII, no.17, (January 8). Bethesda: Education Week.

Ewing, Larry E. 1990. "Perceptions of School Administrators and School Officials Regarding Proposed Changes in Missouri's Classification and Evaluation Program." Columbia: University of Missouri. First Search, Dissertation Abstracts Online, Accession No. AAG9109334.

Finn, Jr., Charles E. 1990. "Restructuring Will Not Improve Schools," in America's Future: Opposing Viewpoints, William Dudley and Bonnie Szumski, eds. San Diego: Greenhaven Press.

Flinchbaugh, Robert W. 1993. The 21st Century Board of Education; Planning, Leading, Transforming. Lancaster: Technomic Publishing Co. 
Greenawalt, II, Charles E., ed. 1994. Educational Innovation: An Agenda to Frame the Future. New York: University Press of America.

Hodgkinson, Harold L. 1996A. “A Demographic Look At Tomorrow,” in Straight Talk About America's Public Schools: Dispelling the Myths, Larry W. Barber, ed. Bloomington, Phi Delta Kappa.

1996 "Reform Versus Reality," in Straight Talk About America's Public Schools: Dispelling the Myths, Larry W. Barber, ed. Bloomington, Phi Delta Kappa.

Horatio Alger Association of Distinguished Americans, 1998. State of Our Nation's Youth, 1998-1999, (http://www.horatioalger.com/pubmat/foreward.htm).

Hoy, Wayne K., and Cecil G. Miskel. 1996. Education Administration: Theory, Research and Practice. New York: McGraw-Hill.

Hoyle, John R. 1995. Leadership and Futuring, Making Visions Happen. Thousand Oaks: Corwin Press.

Huelskamp, Robert M. 1993. "Perspectives on Education in America." Phi Delta Kappan, vol. 74, no. 9, (May). Bloomington: Phi Delta Kappa.

Iowa Association of School Boards and Iowa State Board of Education. 1994. School Board Leadership: The Future. Des Moines.

Jones, Mary Sue McClelland. 1992. “A Model for the Selection of Superintendents by School Board Members in Texas." Lubbock: Texas Tech University. First Search, Dissertation Abstracts Online, Accession No. AAG9325758.

Jones, Rita S. 1984. "Schooling for the 21st Century: A Delphi Study of Future Issues in Education as Identified by Educational Planners." Philadelphia: University of Pennsylvania. First Search, Dissertation Abstracts Online, Accession No. AAG8416368.

Kennedy, Paul. 1990. Interview by Robert Hielbroner, "The U.S. Is in Decline," in America's Future: Opposing Viewpoints, William Dudley and Bonnie Szumski, eds. San Diego: Greenhaven Press.

1993. Preparing For The Twenty-First Century. New York: Random House.

Kerr, Stephen T. 1996. Technology and the Future of Schooling. Chicago: National Society for the Study of Education. 
Kirst, Michael W., and James W. Guthrie. 1994. "Goals 2000 and a Reauthorized ESEA: National Standards and Accompanying Controversies," in The Future of Education: Perspectives on National Standards in America, Nina Cobb, ed. New York: College Entrance Examination Board.

Kniceley, Andy. 1998. “Ads in Schools: What Are We Teaching Our Children?” Clarksburg Telegram, vol 137, no. 106, (December 9). Clarksburg, WV: Clarksburg Publishing Company.

Knoblock, Ron. 1998. "Connecting Schools to Cyberspace." Clarksburg Exponent-Telegram, vol. 73, no. 8, (November 29). Clarksburg, WV: Clarksburg Publishing Company.

Kouzes, James M., and Barry Z. Posner. 1996. "Seven Lessons for Leading the Voyage to the Future," in The Leader of the Future, by Frances Hesselbein, Marshall Goldsmith and Richard Beckhard. San Francisco: Jossey-Bass.

Kuriam, George Thomas, and Graham T. Moliter, eds. 1996. Encyclopedia of the Future. New York: Simon and Schuster McMillan.

Lamm, Richard D., and Richard A. Caldwell. 1996. "Don't Blame the Schools for Changes in Values, Culture, and Families," in Straight Talk About America's Public Schools: Dispelling the Myths, Larry W. Barber, ed. Bloomington: Phi Delta Kappa.

Leaken, Paul. 1998. "Outlook Fair for State Economy." Clarksburg Exponent-Telegram, vol. 89, no. 142, (November 14). Clarksburg, WV: Clarksburg Publishing Company.

Lieberman, Myron. 1993. Public Education: An Autopsy. Cambridge: Harvard University Press.

Loveless, Tom. 1994. "The Politics of National Standards," in The Future of Education: Perspectives on National Standards in America, Nina Cobb, ed. New York: College Entrance Examination Board.

Lowe, Robert, and Barbara Miner. 1992. False Choices: Why School Vouchers Threaten Our Children's Future. Milwaukee: Rethinking Schools. First Search, ERIC No. ED356283.

Lutz, Frank W., and Robert M. Iden. 1994. “The Political Effects of Site-Based Decision Making on Local School Governance in the State of Texas." Washington: United States Department of Education, Office of Educational Research and Improvement (OERI). ERIC Document Reproduction Service, Accession No. ED378636. 
Mann, Dale, and Judith Lawrence. 1984. "A Delphi Analysis of the Instructionally Effective School.” Washington: United States Department of Education, Office of Educational Research and Improvement (OERI). ERIC Document Reproduction Service, Accession No. ED249580.

Manno, Bruno V., Chester E. Finn, Jr., Louann A. Bierlein, and Gregg Vanourek. 1998. “How Charter Schools Are Different." Phi Delta Kappan, vol. 79, no. 7, (March). Bloomington: Phi Delta Kappa.

Margolin, Arnie, and Linda Crone-Koshel. 1998. Tomorrow's Teachers, The Future Supply and Demand for West Virginia Teachers: 1998-2010. Charleston, WV: The Education Alliance.

McRae, Hamish. 1995. The World in 2020. Boston: Harvard Business School Press.

Melendez, Sarah E. 1996. "An "Outsider's" View of Leadership," in The Leader of the Future, by Frances Hesselbein, Marshall Goldsmith and Richard Beckhard. San Francisco: JosseyBass.

Murphy, J. 1990. "Restructuring America's Schools." The Policy and Planning Center, Appalachia Educational Laboratory, Charleston, WV, and the National Center for Educational Leadership, Nashville.

Natale, Jo Anna. 1996. "Growing Up The Hard Way," in Straight Talk About America's Public Schools: Dispelling the Myths, Larry W. Barber, ed. Bloomington: Phi Delta Kappa.

Nathan, Joe. 1998. "Heat and Light in the Charter School Movement." Phi Delta Kappan, vol. 79, no. 7, (March). Bloomington: Phi Delta Kappa.

National Commission on Excellence in Education. 1983. A Nation at Risk. Washington: United States Department of Education.

National School Boards Association. 1987. "American School Boards: The Positive Power." Washington: United States Department of Education, Office of Educational Research and Improvement (OERI). ERIC Document Reproduction Service, Accession No. ED290202.

Network for Effective Schools. 1987. "Expecting the Best: Effective Public Education for All Students. A Report on the Findings of a Major School Reform Study.” First Search, ERIC Accession No. ED282950. 
O’Brien, Thomas V. 1994. "Educational Reform Movements Among the States in the Last 10 Years," in Educational Innovation: An Agenda to Frame the Future, Charles E. Greenawalt, II, ed. New York: University Press of America.

O'Donnell, Peggy. 1988. "Preparing Schools for the Year 2000. The Impact of Technology on America's Classrooms in the Decade Ahead." Washington: United States Department of Education, Office of Educational Research and Improvement (OERI). ERIC Document Reproduction Service, Accession No. ED302223.

Olson, Jeffrey J. 1993. "The Future of School District Reorganization in the State of Minnesota." Minneapolis: University of Minnesota. First Search, Dissertation Abstracts Online, Accession No. AAG9328373.

Orrill, Robert. 1994. "Titanic Structure of Human Scale: School Reform at the Close of the Twentieth Century," in The Future of Education: Perspectives on National Standards in America, Nina Cobb, ed. New York: College Entrance Examination Board.

O'Shell, Wallace D. 1986. “A Delphi Study of the Future Activities of the School Psychologist as Perceived by Superintendents, School Board Members, School Psychologists and Trainers of School Psychologists.” Pittsburgh: University of Pittsburgh. First Search, Dissertation Abstracts Online, Accession No. AAG8620307.

Padro, Susan. 1978. "Survey of Staff Development and Curriculum Services for Quality Education, Part II - Delphi Studies on Curriculum Services and Quality Education." Washington: United States Department of Education, Office of Educational Research and Improvement (OERI). ERIC Document Reproduction Service, Accession No. ED197442.

Perelman, Lewis J. 1992. School's Out. New York: Avon Books.

Plewes, Thomas J. 1992. “Workforce Trends, Workplace Trends: How They Dictate a Changing Education and Training Strategy." Paper presented at the Work Now and In The Future Conference, Portland, Oregon.

Regional Research Institute. 1992. West Virginia Population Projections by County, Age, and Sex - 1990-2020. Morgantown: West Virginia University.

Riley, Richard W. 1996. "Education: The Gateway to America's Future," St. Louis. http://www.ed.gov/Speeches/02-1996/speech.htm).

Rittenmeyer, Dennis C. 1990. "Social Ills Make School Reform Impossible," in America's Future: Opposing Viewpoints, William Dudley and Bonnie Szumski, eds. San Diego: Greenhaven Press. 
Romney, Valerie A. 1996. Strategic Planning and Needs Assessment for Schools and Communities. Fairfax, VA: National Community Education Association.

Rose, Lowell C. 1996. "Straight Talk About The Public Schools," in Straight Talk About America's Public Schools: Dispelling the Myths, Larry W. Barber, ed. Bloomington: Phi Delta Kappa.

Rose, Lowell C., and Alex M. Gallup. 1998. "The 30th Annual Phi Delta Kappa/Gallup Poll of the Public's Attitudes Toward The Public Schools." Phi Delta Kappan, vol. 80, no. 1 (September). Bloomington: Phi Delta Kappa.

Rosenberger, Michal, Larraine. 1993. "The Role Acquisition Process of a Local School Board Member in Texas." Austin: The University of Texas at Austin. First Search, Dissertation Abstracts Online, Accession No. AAG9323540.

Rothstein, Richard. 1998. The Way We Were? The Myths and Realities of America's Student Achievement. New York: The Century Foundation Press.

Salomon, Gavriel, and David Perkins. 1996. "Learning in Wonderland: What Do Computers Really Offer Education?" in Technology and the Future of Schooling, by Stephen T. Kerr. Chicago: National Society for the Study of Education.

Scannel, Dale P. 1972. "The Use of the Delphi Technique to Gain Consensus of the Professional Education Components of Teacher Certification Requirements in Kansas. Final Report." Washington: United States Department of Education, Office of Educational Research and Improvement (OERI). ERIC Document Reproduction Service, Accession Number ED072025.

Schlechty, Phillip C. 1990. Schools for the Twenty-first Century, Leadership Initiatives for Educational Reform. San Francisco: Jossey-Bass.

Schmid, Randolph. 1998. "West Virginia Population Declines." Clarksburg Exponent-Telegram, vol 89, no. 77, (December 31). Clarksburg, WV: Clarksburg Publishing Co.

School Laws of West Virginia. 1997. Charlottesville: The Michie Company.

Slaten, Jonathan R., et.al. 1994. “A Comparison of School Board Members' and Superintendents' Ethical Reasoning Processes." Paper presented to the Southwest Educational Research Association, San Antonio, TX, (January 24-27).

Spring, Joel. 1976. The Sorting Machine, National Educational Policy Since 1945. New York: David McKay Co. 
Stead, Floyd L. 1975. An Application of the Delphi Method of Forecasting to Nursing Education Planning in West Virginia. Doctoral Dissertation, Morgantown: West Virginia University.

Stealy, Robert F. 1998. "Sometimes, the More Advanced Notice, the Better." Clarksburg Telegram, vol. 137, no. 31, (April 12). Clarksburg, WV: Clarksburg Publishing Co.

Stokes, Ernest W. 1981. "Establishing Guidelines for the Evaluation of School Boards and School Board Members in South Carolina School Districts." Columbia: University of South Carolina. First Search, Dissertation Abstracts Online, Accession No. AAG8416368.

Strange, Susan. 1990. "The U.S. Is Not in Decline," in America's Future: Opposing Viewpoints, William Dudley and Bonnie Szumski, eds. San Diego: Greenhaven Press.

Tanner Daniel. 1993. “A Nation 'Truly’ at Risk.” Phi Delta Kappan, vol. 75, no. 4, (December). Bloomington: Phi Delta Kappa.

Thom, Douglas J. 1990. "Financing Elementary and Secondary Education in Ontario: Toward the Future." Washington: United States Department of Education, Office of Educational Research and Improvement (OERI). ERIC Document Reproduction Service, No. ED324759.

Thurow, Lester C. 1997. The Future of Capitalism. New York: Penguin Books.

Toffler, Alvin. 1970. Future Shock. New York: Random House.

1990. Power Shift: Knowledge, Wealth and Violence at the Edge of the 21 st Century. New York: Bantam.

Tunstall, Dorothy F. 1995. Is Your School Ready for the 21st Century? Washington: United States Department of Education.

Tyack, David, and Larry Cuban. 1995. Tinkering Toward Utopia, A Century of Public School Reform. Cambridge: Harvard University Press.

Uchida, Donna, Marvin Cetron and Floretta McKenzie. 1996. Preparing Students for the 21st Century. Arlington: American Association of School Administrators.

Wagner, Tony. 1998. "Change as Collaborative Inquiry." Phi Delta Kappan, vol 79, no. 7, (March). Bloomington, Phi Delta Kappa. 
Walsh, Mark. 1998. “Green Light for School Vouchers?” Education Week, vol. XVIII, no. 12, (November 18). Bethesda: Education Week.

1998. "Vouchers Yield Mixed Results, Report Says." Education Week, vol. XVIII, no. 14, (December 2). Bethesda: Education Week.

Webber, Charles F. 1995. "School Board Members' Perceptions of the Future: Patterns and Implications." Washington: United States Department of Education, Office of Educational Research and Improvement (OERI). ERIC Document Reproduction Service, Accession \#383110.

1995. "A Profile of the School Superintendency: Issues and Perceptions." Washington: United States Department of Education, Office of Educational Research and Improvement (OERI). ERIC Document Reproduction Service, Accession \#383111.

Weil, Nellie C. 1987. "The Significance of Being a School Board Member." American School Boards: The Positive Power. Alexandria: National School Boards Association.

West Virginia Kids Count Fund. 1997. West Virginia Kids Count Data Book. Charleston, WV: West Virginia Kids Count Fund.

Wirt, Frederick M., and Michael W. Kirst. 1992. Schools in Conflict. McCutchan: Berkeley.

Young, Kenneth, and Powell Toth. 1985. "Master Plan for Excellence." Unpublished position paper. 
Appendix A

\section{Correspondence}


204 Maple Lake

Bridgeport, WV 26330

July 31, 1998

Dear

I am writing to ask you to participate in an exciting endeavor.

As , you are being invited to become a member of an expert panel of approximately 45 persons who are widely considered to be among the most knowledgeable about public education in this state. The study in which you will participate is being undertaken for my doctoral dissertation at West Virginia University and will address the future of our state's public education.

Using the Delphi method of forecasting, my dissertation will provide information from this panel on the nature and types of events that will affect public education in West Virginia over the next two decades. The study will attempt to determine:

1. What events will occur that will affect public education in West Virginia between the present and the year 2020?

2. When will these events occur between the present and the year 2020?

3. What degree of impact will each of these events have, should it occur?

4. Will each event be desirable, or undesirable?

The Delphi method of forecasting utilizes expert opinion and group consensus to predict events in the future. This study will be conducted during the fall of 1998 and will consist of three separate surveys, or rounds. First, you will be asked to identify events that you feel will occur that will have some impact on public education. During the second round, you will be given all first round responses from the panel and asked to indicate when each might occur, and to rate their level of impact and desirability. In the third and final round, your second round responses will be compared with the others from the panel in an attempt to gain consensus.

Once the events have been identified, scenarios will be constructed describing when they might occur between the present and the year 2020. The scenarios will enable us to anticipate and plan for the future. As educators, we want the good things to happen sooner, and the bad things to happen later, or not at all. Being aware and being prepared for what might occur are both critical to the continued success of public education in West Virginia. 
July 31,1998

NAME

Page 2

As a member of the panel, your identity will remain strictly confidential. All contact will be made through the mail, and all correspondence will be identified by number. You will be personally contacted only in the event I might need some clarification on your responses. Although some time may be required to complete the second and third rounds, check lists will be used on all surveys in order to minimize your time in completing them.

This project will only be as good as the people I have identified as participants in the expert panel, and their willingness to be a part of this study. Without the best and most knowledgeable people on the panel, the results of the project will be less than desirable. Your commitment is critical to the success of the project, and I strongly encourage you to participate. It should prove to be interesting to see how accurately the future of public education in West Virginia can be forecast. As we await that future, this study will provide us with scenarios which we might anticipate and subsequently plan for. Each member of the panel will receive a copy of the final summary report which will include the scenarios.

Trusting that you find this study sufficiently intriguing to participate in, I will telephone you during the week of August 10 to answer any questions and confirm your participation. Until then, thank you for giving my project your utmost consideration. Should you have any questions which I might address prior to that time, I may be reached during the day at the Harrison County Board of Education office at 304 624-3304, or in the evening at home at 304 842-2009.

Sincerely,

Carl H. Friebel, Jr.

CHF/tih 
Return Address

August 14, 1998

Dear

Thank you for your willingness to serve as a member of the expert panel on the future of public education in West Virginia. Your input will be extremely valuable in establishing a "roadmap" for the early part of the twenty-first century.

I will be back in touch with you by mail prior to the first round of the study.

Again, I greatly appreciate your commitment to this study.

Sincerely,

Carl H. Friebel, Jr.

CHF/tih 
Office of the Dean

Septcmber 8, 11558

MEMORANDUM

TO:

Carl Friebel, Jr.

FROM:

Ernest R. Goeres

Associate Lean

RE:

Human Resources \& Education H.S.\#98-117

Title: "An Application of the Delphi Method of Forecasting to the Future of Public lducation in West Virginia"

Your Application for Excmption for your above-captioned research project has been reviewed under the Human Subjects Policies and has been approved. Attached is the original of your cover letter with the signed stamp of approval. This tmust accompany your survey or questionnaire.

This exemption will remain in effect on the condition that the research is carried out cxactly as described in the application.

Best wishes for the success of your research.
Aftachoncint
ce: Deans Office
Student Advising and Records
Phyllis Durden, Advisor

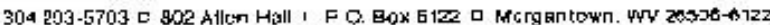




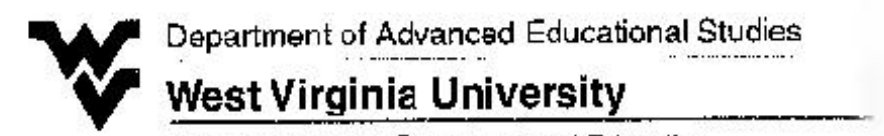

College of Human Ressources and Education

September 11,1998

Dear Panel Member.

In one week, the Delphi study on the future of public education in West Virginia will begin. The Round 1 survey instrument will be mailed to all panel members on friday, September 18. Hogefully, all participants will receive their survey no later than Monday, September 21.

During the uperming week, please begin to consider what events might occur that could affect West Virginia public education between now and the year 2020. The responses you offer on the survey may relate to any area of public cducation including, bui not limited to curriculum, personnel, finance, facilities, and governance, or may represent your particular interest or specialty.

Promptness in completing and returning the survey is critical to the success of the Delphi methodology. Please make every effort to respond to each survey and return it in the selfaddressed, stamped envelope by the date specified. Your prompt attention to the completion and return of each survey is most appreciated.

The WVU Institutional Review Board for the Protection of Human Subjects requires that I inform you of the following: your participation in this study is voluntary and you do not have to respond to every ilem, and complete anonymity will be maintained.

study.

$\Lambda$ sain, thank you for your willingress to serve as a panel member for this important

Sincerely,

Carl H. Friebel, Jr.

\section{CHF/tih}

\footnotetext{
Educational Leadership Studice - Educational Psychology • Social and Cultural Follncatlons - Technology Educatlon

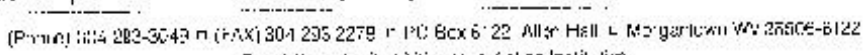

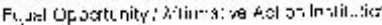


Appendix B

Survey Instruments 


\section{Department of Advanced Educational Studies West Virginia University}

College of Human Resources and Education

September 18, 1998

Dear Pancl Member,

Attached is the Round 1 response sheet for the Delphis study on the future of public ectucation in West Virginia. Directions for its completion are located at the top of the response sheet.

The number which appears in the upper right comer of the response shext has been assigned to you for tabulation purposes only. This number will be used throughout the study. Your name will not be linked in any way with any of the responses. In the event you choose not to list any events on the Round 1 response sheet, plesse return it to me anyway so that I will know that you received it. Even if you do not list any events in Round 1, you will still be sent the Round 2 and 3 surveys to respond to.

An important aspect of Delphi studies is the prompt return of information from the pane? members as well as the return of Rounds 2 and 3 by the investigator to the participants 1 would be most appreciative if you would complete the Round 1 response sheet by Saturday, September 26,1998 , and retum it in the self-addreseed, stanjped envelope.

Should you have ary questions about the Round l response shoet, please feel free to contact me during the day at 304 624-3304, in the evening at 304 842-2009, or by e-mail at cfiebel@wru.edu.

Thank you for your prompt attention to completing and returning the Round 1 response sheet.

Sincerely,

Carl H, Friebel, J.

CHFitih 


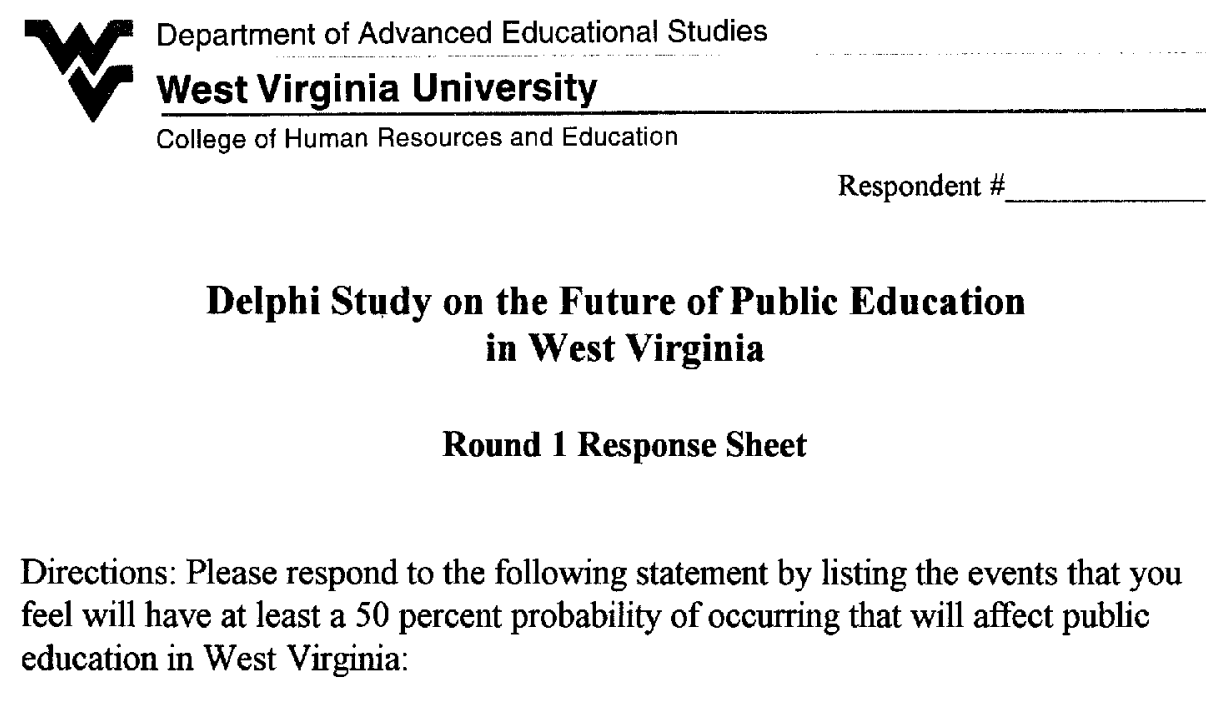

As I view the future of public education in West Virginia between now and the year 2020, the following events might or should take place. (Please use additional sheets of paper if necessary.)

Educational Leadership Studies • Educational Psychology • Social and Cultural Foundations • Technology Education 
Department of Advanced Educational Studies

West Virginia University

College of Human Fesources and Education

October 7,1998

Dear Panel Member,

Attached is the kound 2 response shect for the Delphi study on the future of public education in West Virginia. Round 2 conlains an edited list of the usable responses from .Round 1. Directions for its completion are al Lached lo the instrument.

I would be most appreciative if you would complete and return the Round 2 survey by October 16, 1998 , in the self-addressed, stamped envelope.

Should you have any questions about the Round 2 survey, please feel free to contact nrc during the day at 304 624-3304, in the evening at 304 842-2009, or by e-mail at cfriebel@iswu.edu.

shect.

Thank you for your prompt attention to completing and retuming the Round 2 response

Simcerely,

Carl H. Friebel, Jr.

CHFitili

Educational Leadership Slldies - Educational Psycholopy - Social and Gultuml Foundations - Technology Education

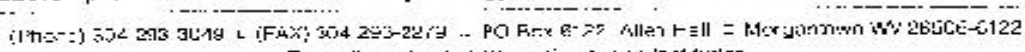

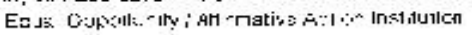




\title{
Delphi Study on the Future of Public Education in West Virginia
}

\author{
Round 2 Response Sheet
}

Instructions
Column 1-Event provides a numerical listing of all events supplied from Round 1.
Column 2-Time provides space for you to estimate the date of occurrence of each event listed.
- place an " $X$ " in the box directly below the time interval in which, in your opinion, the event has a $50 \%$ chance of occurrence.
- use the "After 2020" date option if you believe the event has a chance of occurrence after 2020 .
- use the "Never" date option if you believe the event described is highly improbable.

Column 3 - Impact provides space for you to record your judgement of the impact of each event, were it to occur. This is not a judgement of desirability, but of impact. Highly desirable as well as highly undesirable events can each have a very great or virtually no impact on public education. Place an " $\mathrm{X}$ " in the appropriate column following each event.

Column 4 - Desirability provides space for you to record your judgement of the desirability of each event. Place an " $X$ " in the appropriate column following each event.

Column 5 -Comments provides space for you to make any remark you may wish to enter there.

PLEASE NOTE:

On the first page of the questionnaire is the number assigned to you. This number will be used for tabulating purposes only. Your name will not be linked in any way with any of the responses. 


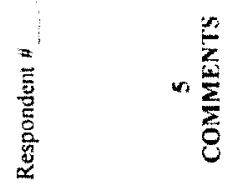

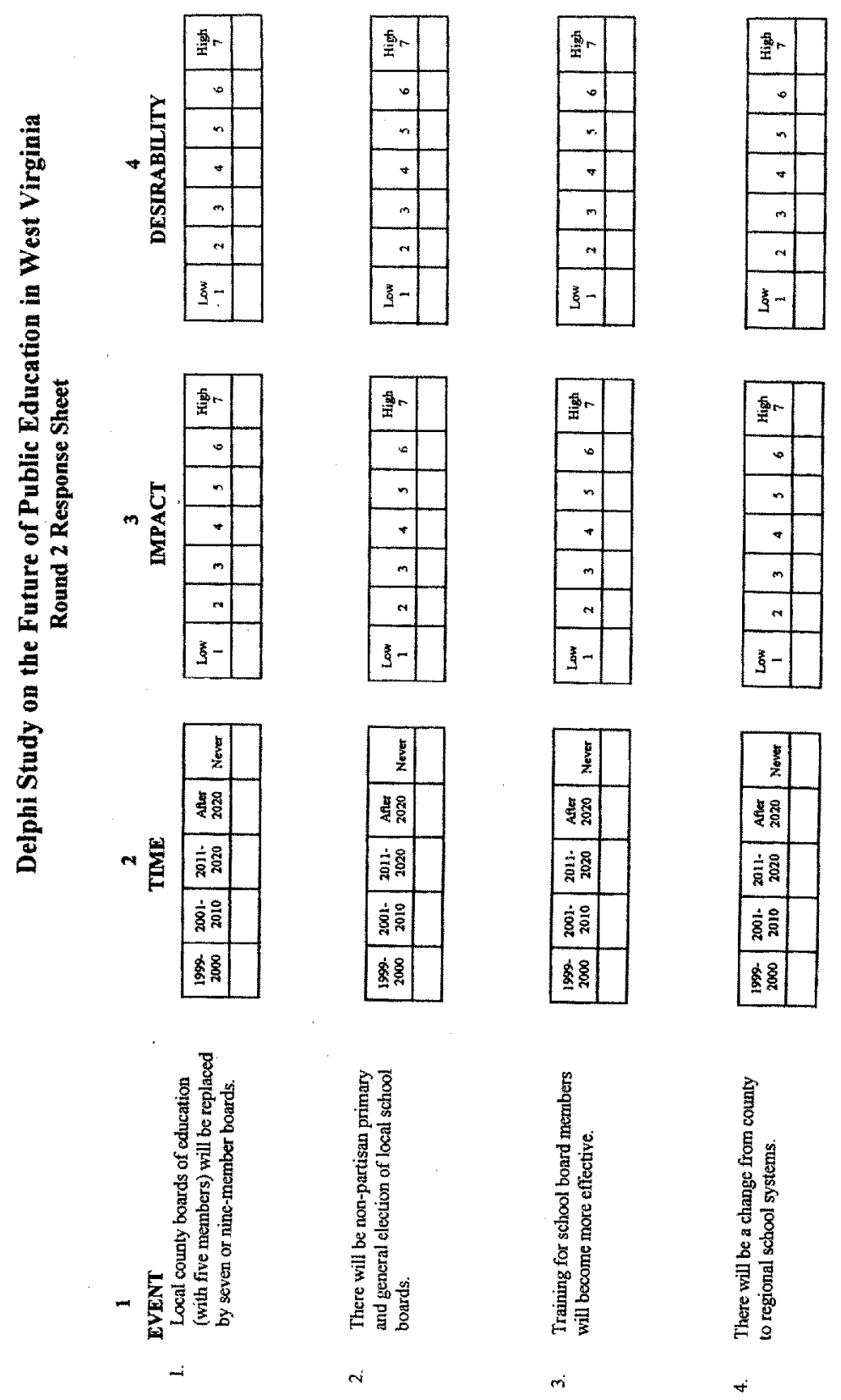




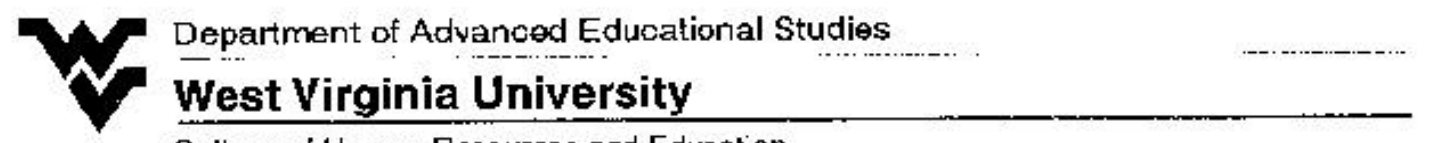

College of Human Resources and Education

October 26, 1998

Dear Panel Member,

Enclosed is the kound 3 Response Shee lot the Delphi study on the future of public education in West Virginia. This is the final round ol the study. Directions for its completion are attached.

The median group response may be defuned as the central point in the time fiame seclion of the Round 2 Response Sheel which the group believed the event in question would occur. If you do not agree with the group conscnsus, please briefly explain why you disagrce.

I would be most appreciative if you would complete and retum the Rownd 3 responsc sheet by Novembur 2, 1998, in the self-addreszed, stamped envelope.

Should you have any questions about the Round 3 survey, please feel free to contact me diring the day at $304624-3304$, in the evering at $304842-2009$, or by e-mail at efriebelowru.edu.

Thank you for youx primpt alteulion to completing and returning the Round 3 response form. Your continued support and attention to my prọject is most appreciated.

Sincerely,

Carl TI. Friebel, Jr.

CHF/th

inclosures

Educaucnal Leadership Siludies - Educational Psychelogy - Social and Cultural Foundations - Technology Education

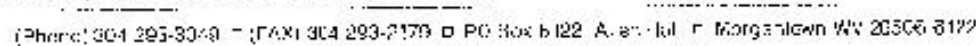

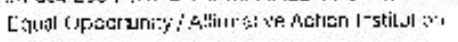




\section{Delphi Study on the Future of Public Education in West Virginia}

\section{Round 3 Response Sheet}

\section{$\underline{\text { Instructions }}$}

Column 1 provides a numerical listing of the events.

Column 2 gives your previous estimate of the interval during which each event has a $50 \%$ probability of occurrence.

Column 3 lists the interval in which the median group response fell, in response to Round 2 of the survey.

Column 4 provides space in which you may furnish a new estimate of the interval during which the event has a $50 \%$ chance of occurrence. Please indicate your new estimate by marking the appropriate column, even if your estimate has not changed from the one you gave in response to Round 2 of the study.

Column 5 provides space for you to record a brief explanation of your current estimate if it is different from the median group response. 


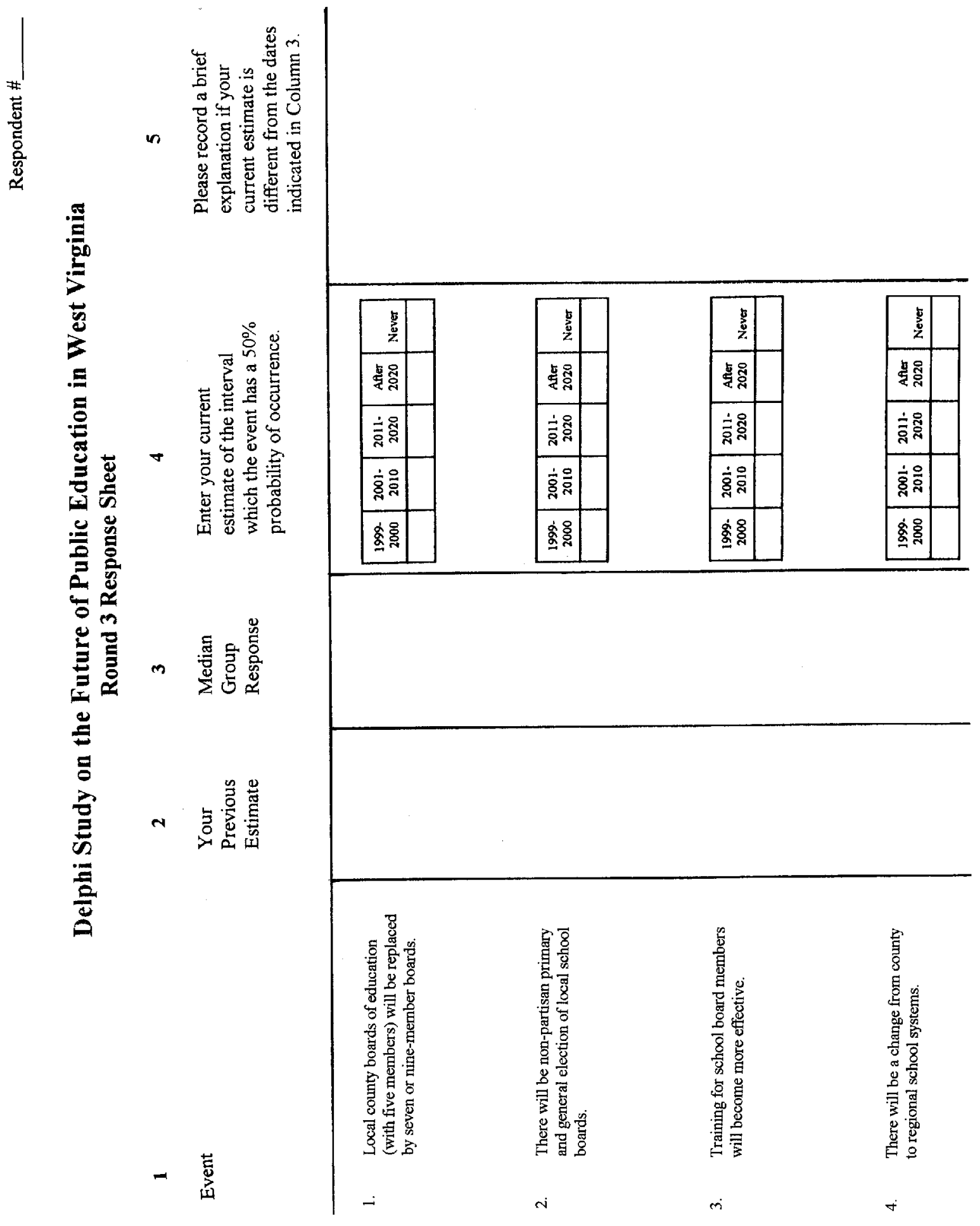


Appendix C

List of Original Events 


\section{Delphi Study on the Future of Public Education in West Virginia List of Original Events}

1. Local county boards of education (with five members) will be replaced by seven or ninemember boards.

2. There will be non-partisan primary and general election of local school boards.

3. Training for school board members will become more effective.

4. There will be a change from county to regional school systems.

5. Services provided by Regional Education Service Agencies (RESA) will expand.

6. County school systems will be serviced regionally (transportation, nutrition services, curriculum specialists).

7. Services (transportation, food services, maintenance) will be contracted.

8. County school boards will be eliminated.

9. Special interest groups will increase, becoming more active and more vocal.

10. School-based governance will erode the authority of local school boards.

11. State government will play a more prominent role in education.

12. The Legislature will deregulate education.

13. There will be closure on the role of the courts in the interpretation of "thorough and efficient education."

14. Distance learning opportunities will increase as staff cuts occur and world-class instruction in specialized areas will be provided.

15. All schools will be networked via computers.

16. There will be computer connections between home and school.

17. Federal legislation will be passed allowing for continual E-rate funding.

18. Every student and teacher will have their own computer equipment and Internet access. 
19. Computers will change the education structure to allow for flexible scheduling for students.

20. Much of the school time of children will be spent in places other than a traditional school building (e.g., home, library, offices, workplaces, specialized labs).

21. Two-way cameras will allow for interaction between teachers and students.

22. Increased use of computers and distance learning will reduce the number of teachers needed.

23. There will be increased emphasis on the use of technology in teacher training programs.

24. Accountability standards for students will be enacted.

25. Grades for students will be replaced by comprehensive electronic portfolios that describe the student's capabilities, potential and past accomplishments.

26. Hard copy, paper textbooks will be replaced by electronic texts.

27. The emphasis on computer skills will diminish when it is realized that computers are simply tools for well-prepared educators to use and they do not teach students to think, read, write, appreciate the arts, challenge and improvise.

28. WV will fall behind neighboring states in use of educational technology.

29. Comprehensive, specialized software that will be customized for each student will be developed and constitute "the curriculum."

30. Teacher avatars (computerized embodiments of another person - a sports figure, celebrity, etc.) will allow students to choose and interact with who they are most comfortable learning from.

31. Students will earn credits by taking "official" achievement tests to demonstrate subject mastery on their computers.

32. Speech recognition software will replace the need to have keyboarding skills.

33. A national testing program will be established.

34. A state curriculum and standards will be established that will drive what is taught and tested. 
35. The state assessment program will be revised.

36. More emphasis will be placed on assessment of student performance including test scores, skills, and trades.

37. High school graduation requirements will increase.

38. Students will have more independent study classes in which they will complete projects for credit.

39. There will be an increased emphasis on school to work from business and industry.

40. Businesses will become more involved in student training through mentorships and research "fellowships."

41. School to work will be scrapped.

42. Education will become more focused on teaching problem solving, access to data bases, and the use of technology.

43. All teacher training programs will take 5 years to complete.

44. Programs will be developed for all 3 and/or 4 year olds.

45. State certification will be required for pre-school teachers.

46. Schools will increasingly become involved with other agencies in solving the problems of society.

47. There will be an increase in discipline problems and need for alternative education programs.

48. Students will be held more accountable for questionable behavior.

49. After-schools programs will expand.

50. There will be an increasing emphasis on foreign language programs.

51. A foreign language will be offered in all elementary schools.

52. Schools will emphasize more cultural programming (art, music, theater). 
53. Schools will serve as centers for health, social and recreational services and academic support.

54. Public confidence and support in public education will be restored.

55. Closer relationships between the public schools and institutions of higher education will form to increase accessibility of public education.

56. A system of merit pay will be enacted.

57. The funding of education will become the responsibility of the state with little or no local discretionary funding.

58. A statewide school excess levy will be approved.

59. There will be a decrease in the number of local school levies.

60. The percentage of local bond passages will improve.

61. There will be a major revision to the school-aid formula.

62. Funding for a new formula will be provided by general revenue sources, not property taxes.

63. Advertising in the schools and sponsorship of athletic teams will begin.

64. Teacher salaries in WV will rise above the national average.

65. Staff development will require paid additional/extended days for teachers.

66. A national/universal health care program will be established.

67. There will be more federal funding and more federal control.

68. Funding for education will be diverted to meet the health care needs of the elderly.

69. A voucher system of some sort will occur.

70. Public school choice will be enacted.

71. Charter school legislation will be adopted in WV.

72. Private schools will increase in number. 
73. Private schools will not be able to select or discriminate among students.

74. Private schools may lead to a resurrection of boarding schools for the children of busy, upwardly mobile, two income families.

75. The state will audit and continue to set standards, but the private sector will deliver the services (through computer assisted instruction).

76. Facilities construction will become more and more a state function rather than a county function.

77. School consolidation will continue, but will slow down.

78. Schools will become larger.

79. There will be a continued move to middle school concept.

80. Counties with rapidly increasing enrollments will experience financial and political problems in providing facilities and quality staff.

81. Federal government will provide funding for replacement of aging school buildings.

82. Indoor air quality will be legislated for all new schools.

83. Radon testing will be legislated for all new schools.

84. Every school will be air conditioned.

85. Security systems will be installed in all public schools.

86. There will be a phone on every teacher's desk.

87. Personnel laws will be revised so that they are more favorable to employers.

88. There will be a return to "best qualified," not "most senior," when selecting teachers.

89. Professional tenure for teachers will be eliminated.

90. There will be more flexibility of certification laws to allow for greater mobility to meet staffing demands including interstate and international licensure.

91. Degree programs will be offered for administrators working in finance, transportation, and nutrition service. 
92. There will be a statewide teacher shortage.

93. Certification requirements will be reduced during a teacher shortage.

94. Alternatives to traditional college teacher education programs will be established to certify school teachers.

95. There will be an even greater shortage of administrators than teachers.

96. There will be an increase in the number of females entering administrative positions.

97. Staffing limits under the state aid formula will increase.

98. Teachers will become much more specialized and focus on narrow content areas.

99. There will be competency testing for teachers and administrators.

100. There will be more emphasis on teaching as a profession.

101. The Rule of 80 will be passed by the Legislature.

102. There will be a nurse in every school.

103. Retirement system restrictions will be relaxed to permit retired teachers to re-enter teaching to offset a teacher shortage.

104. Teachers who do not have teaching certificates will be recruited from the private sector.

105. Collective bargaining will be enacted.

106. There will be a loss of quality leadership due in part to lack of interest in the principalship by certified and qualified teachers.

107. Schools will become year round in most or all counties.

108. The length of the school year will be extended.

109. The length of the school day will be extended.

110. Child care services will be available at the schools.

111. There will be a national insistence on the return to civility in schools. 
112. Comprehensive student advisement programs will be developed.

113. Cross-county attendance will be routine as attendance will be determined by geographic distance, not political boundaries.

114. Compulsory school attendance laws will be redefined to allow students to stay at home with computers and use distance learning.

115. Laws governing the discipline of special education students will be relaxed.

116. Programs will be designed for special needs students rather than being placed in a normal classroom situation (inclusion).

117. There will be greater involvement by educators in state and local economic development.

118. Parents will be taught to be educational consumers (life-long learners) and parental involvement will increase.

119. More retirees will become school volunteers.

120. Prayer will return to the public schools.

121. All students will have IEPs (Individualized Education Plans).

122. The statewide college-going rate will exceed $66 \%$.

123. There will be a continued out-migration to other states by high school and college graduates, and young families with children.

124. Home school students will be allowed to participate on high school athletic teams.

125. The number of students being home-schooled will increase.

126. West Virginia will experience significant economic growth.

127. The standard of living in West Virginia will improve.

128. West Virginia will become an information-based economy.

129. The stock market will plummet to a record low, affecting state investments.

130. The NEA (National Education Association) will merge with the AFT (American Federation of Teachers). 
131. The WV Department of Education will be downsized.

132. The two boards of higher education will be eliminated.

133. A self-standing community college system will be created.

134. Secondary vocational programs and community colleges will be under one administrative unit. 


\section{Appendix D}

List of Events by Time Frame 


\section{List of Events By Time Frame}

$2001-2010$

3. Training for school board members will become more effective.

5. Services provided by Regional Education Service Agencies (RESA) will expand.

6. County school systems will be serviced regionally (transportation, nutrition services, curriculum specialists).

7. Services (transportation, food services, maintenance) will be contracted.

9. Special interest groups will increase, becoming more active and more vocal.

11. State government will play a more prominent role in education.

13. There will be closure on the role of the courts in the interpretation of "thorough and efficient education."

14. Distance learning opportunities will increase as staff cuts occur and world-class instruction in specialized areas will be provided.

15. All schools will be networked via computers.

16. There will be computer connections between home and school.

17. Federal legislation will be passed allowing for continual E-rate funding.

19. Computers will change the education structure to allow for flexible scheduling for students.

21. Two-way cameras will allow for interaction between teachers and students.

23. There will be increased emphasis on the use of technology in teacher training programs.

24. Accountability standards for students will be enacted.

31. Students will earn credits by taking "official" achievement tests to demonstrate subject mastery on their computers.

32. Speech recognition software will replace the need to have keyboarding skills.

34. A state curriculum and standards will be established that will drive what is taught and tested. 
35. The state assessment program will be revised.

36. More emphasis will be placed on assessment of student performance including test scores, skills, and trades.

37. High school graduation requirements will increase.

38. Students will have more independent study classes in which they will complete projects for credit.

39. There will be an increased emphasis on school to work from business and industry.

40. Businesses will become more involved in student training through mentorships and research "fellowships."

42. Education will become more focused on teaching problem solving, access to data bases, and the use of technology.

44. Programs will be developed for all 3 and/or 4 year olds.

45. State certification will be required for pre-school teachers.

46. Schools will increasingly become involved with other agencies in solving the problems of society.

47. There will be an increase in discipline problems and need for alternative education programs.

48. Students will be held more accountable for questionable behavior.

49. After-schools programs will expand.

50. There will be an increasing emphasis on foreign language programs.

52. Schools will emphasize more cultural programming (art, music, theater).

53. Schools will serve as centers for health, social and recreational services and academic support.

55. Closer relationships between the public schools and institutions of higher education will form to increase accessibility of public education.

59. There will be a decrease in the number of local school levies.

61. There will be a major revision to the school-aid formula. 
62. Funding for a new formula will be provided by general revenue sources, not property taxes.

63. Advertising in the schools and sponsorship of athletic teams will begin.

65. Staff development will require paid additional/extended days for teachers.

67. There will be more federal funding and more federal control.

69. A voucher system of some sort will occur.

70. Public school choice will be enacted.

71. Charter school legislation will be adopted in WV.

72. Private schools will increase in number.

76. Facilities construction will become more and more a state function rather than a county function.

77. School consolidation will continue, but will slow down.

78. Schools will become larger.

79. There will be a continued move to middle school concept.

80. Counties with rapidly increasing enrollments will experience financial and political problems in providing facilities and quality staff.

81. Federal government will provide funding for replacement of aging school buildings.

82. Indoor air quality will be legislated for all new schools.

83. Radon testing will be legislated for all new schools.

85. Security systems will be installed in all public schools.

88. There will be a return to "best qualified," not "most senior," when selecting teachers.

90. There will be more flexibility of certification laws to allow for greater mobility to meet staffing demands including interstate and international licensure.

91. Degree programs will be offered for administrators working in finance, transportation, and nutrition service. 
92. There will be a statewide teacher shortage.

93. Certification requirements will be reduced during a teacher shortage.

95. There will be an even greater shortage of administrators than teachers.

96. There will be an increase in the number of females entering administrative positions.

97. Staffing limits under the state aid formula will increase.

99. There will be competency testing for teachers and administrators.

100. There will be more emphasis on teaching as a profession.

103. Retirement system restrictions will be relaxed to permit retired teachers to re-enter teaching to offset a teacher shortage.

104. Teachers who do not have teaching certificates will be recruited from the private sector.

106. There will be a loss of quality leadership due in part to lack of interest in the principalship by certified and qualified teachers.

110. Child care services will be available at the schools.

111. There will be a national insistence on the return to civility in schools.

112. Comprehensive student advisement programs will be developed.

113. Cross-county attendance will be routine as attendance will be determined by geographic distance, not political boundaries.

115. Laws governing the discipline of special education students will be relaxed.

117. There will be greater involvement by educators in state and local economic development.

118. Parents will be taught to be educational consumers (life-long learners) and parental involvement will increase.

119. More retirees will become school volunteers.

123. There will be a continued out-migration to other states by high school and college graduates, and young families with children.

124. Home school students will be allowed to participate on high school athletic teams. 
125. The number of students being home-schooled will increase.

127. The standard of living in West Virginia will improve.

130. The NEA (National Education Association) will merge with the AFT (American Federation of Teachers).

132. The two boards of higher education will be eliminated.

2011-2020

4. There will be a change from county to regional school systems.

18. Every student and teacher will have their own computer equipment and Internet access.

20. Much of the school time of children will be spent in places other than a traditional school building (e.g., home, library, offices, workplaces, specialized labs).

22. Increased use of computers and distance learning will reduce the number of teachers needed.

25. Grades for students will be replaced by comprehensive electronic portfolios that describe the student's capabilities, potential and past accomplishments.

26. Hard copy, paper textbooks will be replaced by electronic texts.

29. Comprehensive, specialized software that will be customized for each student will be developed and constitute "the curriculum."

33. A national testing program will be established.

43. All teacher training programs will take 5 years to complete.

51. A foreign language will be offered in all elementary schools.

54. Public confidence and support in public education will be restored.

56. A system of merit pay will be enacted.

57. The funding of education will become the responsibility of the state with little or no local discretionary funding.

58. A statewide school excess levy will be approved. 
60. The percentage of local bond passages will improve.

66. A national/universal health care program will be established.

68. Funding for education will be diverted to meet the health care needs of the elderly.

74. Private schools may lead to a resurrection of boarding schools for the children of busy, upwardly mobile, two income families.

84. Every school will be air conditioned.

86. There will be a phone on every teacher's desk.

87. Personnel laws will be revised so that they are more favorable to employers.

94. Alternatives to traditional college teacher education programs will be established to certify school teachers.

98. Teachers will become much more specialized and focus on narrow content areas.

102. There will be a nurse in every school.

107. Schools will become year round in most or all counties.

108. The length of the school year will be extended.

109. The length of the school day will be extended.

114. Compulsory school attendance laws will be redefined to allow students to stay at home with computers and use distance learning.

116. Programs will be designed for special needs students rather than being placed in a normal classroom situation (inclusion).

121. All students will have IEPs (Individualized Education Plans).

122. The statewide college-going rate will exceed $66 \%$.

126. West Virginia will experience significant economic growth.

128. West Virginia will become an information-based economy.

129. The stock market will plummet to a record low, affecting state investments.

131. The WV Department of Education will be downsized. 
133. A self-standing community college system will be created.

134. Secondary vocational programs and community colleges will be under one administrative unit.

AFTER 2020

8. County school boards will be eliminated.

28. WV will fall behind neighboring states in use of educational technology.

30. Teacher avatars (computerized embodiments of another person - a sports figure, celebrity, etc.) will allow students to choose and interact with who they are most comfortable learning from.

41. School to work will be scrapped.

89. Professional tenure for teachers will be eliminated.

\section{NEVER}

1. Local county boards of education (with five members) will be replaced by seven or ninemember boards.

2. There will be non-partisan primary and general election of local school boards.

10. School-based governance will erode the authority of local school boards.

12. The Legislature will deregulate education.

27. The emphasis on computer skills will diminish when it is realized that computers are simply tools for well-prepared educators to use and they do not teach students to think, read, write, appreciate the arts, challenge and improvise.

64. Teacher salaries in WV will rise above the national average.

73. Private schools will not be able to select or discriminate among students.

75. The state will audit and continue to set standards, but the private sector will deliver the services (through computer assisted instruction).

101. The Rule of 80 will be passed by the Legislature. 
105. Collective bargaining will be enacted.

120. Prayer will return to the public schools. 


\section{Appendix E}

List of Primary and Secondary Events by Time Frame, Impact, and Desirability 


\section{List of Primary and Secondary Events \\ By Time Frame, Impact and Desirability}

\section{PRIMARY EVENTS}

$2001-2010$

High Impact/High Desirability

3. Training for school board members will become more effective.

19. Computers will change the education structure to allow for flexible scheduling for students.

24. Accountability standards for students will be enacted.

42. Education will become more focused on teaching problem solving, access to data bases, and the use of technology.

45. State certification will be required for pre-school teachers.

46. Schools will increasingly become involved with other agencies in solving the problems of society.

48. Students will be held more accountable for questionable behavior.

49. After-schools programs will expand.

53. Schools will serve as centers for health, social and recreational services and academic support.

61. There will be a major revision to the school-aid formula.

65. Staff development will require paid additional/extended days for teachers.

90. There will be more flexibility of certification laws to allow for greater mobility to meet staffing demands including interstate and international licensure.

97. Staffing limits under the state aid formula will increase.

100. There will be more emphasis on teaching as a profession.

112. Comprehensive student advisement programs will be developed. 
113. Cross-county attendance will be routine as attendance will be determined by geographic distance, not political boundaries.

118. Parents will be taught to be educational consumers (life-long learners) and parental involvement will increase.

119. More retirees will become school volunteers.

2001-2010 Primary

High Impact

6. County school systems will be serviced regionally (transportation, nutrition services, curriculum specialists).

14. Distance learning opportunities will increase as staff cuts occur and world-class instruction in specialized areas will be provided.

31. Students will earn credits by taking "official" achievement tests to demonstrate subject mastery on their computers.

34. A state curriculum and standards will be established that will drive what is taught and tested.

37. High school graduation requirements will increase.

71. Charter school legislation will be adopted in WV.

76. Facilities construction will become more and more a state function rather than a county function.

2001-2010 Primary

High Desirability

35. The state assessment program will be revised.

40. Businesses will become more involved in student training through mentorships and research "fellowships."

50. There will be an increasing emphasis on foreign language programs.

83. Radon testing will be legislated for all new schools.

96. There will be an increase in the number of females entering administrative positions. 
117. There will be greater involvement by educators in state and local economic development.

2001-2010 Primary

High Impact/Low Desirability

92. There will be a statewide teacher shortage.

93. Certification requirements will be reduced during a teacher shortage.

2001-2010 Primary

Low Desirability

63. Advertising in the schools and sponsorship of athletic teams will begin.

72. Private schools will increase in number.

124. Home school students will be allowed to participate on high school athletic teams.

125. The number of students being home-schooled will increase.

2001-2010 Primary

Other

5. Services provided by Regional Education Service Agencies (RESA) will expand.

38. Students will have more independent study classes in which they will complete projects for credit.

39. There will be an increased emphasis on school to work from business and industry.

77. School consolidation will continue, but will slow down.

79. There will be a continued move to middle school concept.

91. Degree programs will be offered for administrators working in finance, transportation, and nutrition service.

103. Retirement system restrictions will be relaxed to permit retired teachers to re-enter teaching to offset a teacher shortage.

132. The two boards of higher education will be eliminated. 
NEVER Primary

Other

120. Prayer will return to the public schools.

\section{SECONDARY EVENTS}

2001-2010

High Impact/High Desirability

13. There will be closure on the role of the courts in the interpretation of "thorough and efficient education."

15. All schools will be networked via computers.

16. There will be computer connections between home and school.

17. Federal legislation will be passed allowing for continual E-rate funding.

23. There will be increased emphasis on the use of technology in teacher training programs.

44. Programs will be developed for all 3 and/or 4 year olds.

55. Closer relationships between the public schools and institutions of higher education will form to increase accessibility of public education.

62. Funding for a new formula will be provided by general revenue sources, not property taxes.

81. Federal government will provide funding for replacement of aging school buildings.

88. There will be a return to "best qualified," not "most senior," when selecting teachers.

99. There will be competency testing for teachers and administrators.

110. Child care services will be available at the schools.

111. There will be a national insistence on the return to civility in schools.

115. Laws governing the discipline of special education students will be relaxed.

127. The standard of living in West Virginia will improve. 
2001-2010 Secondary

High Impact

32. Speech recognition software will replace the need to have keyboarding skills.

36. More emphasis will be placed on assessment of student performance including test scores, skills, and trades.

47. There will be an increase in discipline problems and need for alternative education programs.

70. Public school choice will be enacted.

104. Teachers who do not have teaching certificates will be recruited from the private sector.

2001-2010 Secondary

High Desirability

82. Indoor air quality will be legislated for all new schools.

2001-2010 Secondary

High Impact/Low Desirability

9. Special interest groups will increase, becoming more active and more vocal.

11. State government will play a more prominent role in education.

59. There will be a decrease in the number of local school levies.

67. There will be more federal funding and more federal control.

69. A voucher system of some sort will occur.

80. Counties with rapidly increasing enrollments will experience financial and political problems in providing facilities and quality staff.

95. There will be an even greater shortage of administrators than teachers.

106. There will be a loss of quality leadership due in part to lack of interest in the principalship by certified and qualified teachers.

123. There will be a continued out-migration to other states by high school and college graduates, and young families with children. 
2001-2010 Secondary

Other

21. Two-way cameras will allow for interaction between teachers and students.

52. Schools will emphasize more cultural programming (art, music, theater).

78. Schools will become larger.

85. Security systems will be installed in all public schools.

2011-2020 SECONDARY

High Impact/High Desirability

7. Services (transportation, food services, maintenance) will be contracted.

66. A national/universal health care program will be established.

84. Every school will be air conditioned.

107. Schools will become year round in most or all counties.

122. The statewide college-going rate will exceed $66 \%$.

126. West Virginia will experience significant economic growth.

2011-2020 SECONDARY

High Impact

57. The funding of education will become the responsibility of the state with little or no local discretionary funding.

121. All students will have IEPs (Individualized Education Plans).

2011-2020 SECONDARY

High Desirability

20. Much of the school time of children will be spent in places other than a traditional school building (e.g., home, library, offices, workplaces, specialized labs).

43. All teacher training programs will take 5 years to complete. 
51. A foreign language will be offered in all elementary schools.

2011-2020 SECONDARY

High Impact/Low Desirability

68. Funding for education will be diverted to meet the health care needs of the elderly.

2011-2020 SECONDARY

Other

26. Hard copy, paper textbooks will be replaced by electronic texts.

86. There will be a phone on every teacher's desk.

AFTER 2020 SECONDARY

Other

30. Teacher avatars (computerized embodiments of another person - a sports figure, celebrity, etc.) will allow students to choose and interact with who they are most comfortable learning from.

NEVER SECONDARY

High Impact/High Desirability

64. Teacher salaries in WV will rise above the national average.

NEVER SECONDARY

High Desirability

12. The Legislature will deregulate education.

101. The Rule of 80 will be passed by the Legislature.

NEVER SECONDARY

High Impact/Low Desirability

75. The state will audit and continue to set standards, but the private sector will deliver the services (through computer assisted instruction). 
105. Collective bargaining will be enacted.

NEVER SECONDARY

Low Desirability

1. Local county boards of education (with five members) will be replaced by seven or ninemember boards.

2. There will be non-partisan primary and general election of local school boards.

\section{NEVER SECONDARY}

Other

10. School-based governance will erode the authority of local school boards.

27. The emphasis on computer skills will diminish when it is realized that computers are simply tools for well-prepared educators to use and they do not teach students to think, read, write, appreciate the arts, challenge and improvise.

73. Private schools will not be able to select or discriminate among students. 
Appendix F

Rank Order of Mean Impact and Desirability Ratings of Events 
Table 1

Rank Order of Mean Impact and Desirability Ratings of Events 2001-2010 Time Frame

\begin{tabular}{|c|c|c|c|c|}
\hline $\begin{array}{l}\text { Time Frame \& } \\
\text { Event Number }\end{array}$ & $\bar{X}_{I}$ & Rank & $\bar{X}_{\mathrm{D}}$ & Rank \\
\hline 3 & 5.07 & 49 & 6.09 & 8 \\
\hline 5 & 4.40 & 75 & 4.70 & 50 \\
\hline 6 & 5.12 & 42 & 4.67 & 52 \\
\hline 9 & 5.09 & 46 & 2.63 & 70 \\
\hline 11 & 5.56 & 18 & 2.98 & 66 \\
\hline 13 & 5.56 & 18 & 5.44 & 23 \\
\hline 14 & 5.33 & 31 & 4.72 & 49 \\
\hline 15 & 5.50 & 24 & 6.05 & 9 \\
\hline 16 & 5.53 & 22 & 5.88 & 11 \\
\hline 17 & 5.00 & 56 & 5.66 & 14 \\
\hline 19 & 5.56 & 18 & 5.35 & 26 \\
\hline 21 & 4.68 & 67 & 4.24 & 60 \\
\hline 23 & 5.76 & 12 & 6.33 & 2 \\
\hline 24 & 5.98 & 2 & 5.61 & 16 \\
\hline 31 & 5.09 & 46 & 4.47 & 56 \\
\hline 32 & 5.07 & 49 & 4.76 & 46 \\
\hline 34 & 5.71 & 14 & 4.43 & 57 \\
\hline 35 & 4.67 & 68 & 5.12 & 33 \\
\hline 36 & 5.21 & 40 & 4.53 & 55 \\
\hline 37 & 5.12 & 42 & 4.81 & 44 \\
\hline 38 & 4.77 & 63 & 4.67 & 52 \\
\hline 39 & 4.79 & 61 & 4.64 & 54 \\
\hline 40 & 4.74 & 64 & 5.19 & 31 \\
\hline 42 & 5.47 & 26 & 5.56 & 20 \\
\hline 44 & 5.91 & 5 & 5.58 & 19 \\
\hline 45 & 5.11 & 45 & 5.73 & 13 \\
\hline 46 & 5.12 & 42 & 5.00 & 40 \\
\hline 47 & 5.07 & 49 & 4.38 & 59 \\
\hline 48 & 5.42 & 29 & 6.19 & 7 \\
\hline 49 & 5.05 & 54 & 5.65 & 15 \\
\hline 50 & 4.79 & 61 & 5.12 & 33 \\
\hline 52 & 4.52 & 74 & 4.95 & 41 \\
\hline 53 & 5.05 & 54 & 5.22 & 30 \\
\hline
\end{tabular}


Table 1, continued

Rank Order of Mean Impact and Desirability Ratings of Events 2001-2010 Time Frame

\begin{tabular}{|c|c|c|c|c|}
\hline $\begin{array}{l}\text { Time Frame \& } \\
\text { Event Number }\end{array}$ & $\bar{X}_{\mathrm{I}}$ & Rank & $\bar{X}_{D}$ & Rank \\
\hline 55 & 5.67 & 17 & 6.24 & 6 \\
\hline 59 & 5.83 & 9 & 2.79 & 67 \\
\hline 61 & 5.90 & 6 & 5.60 & 17 \\
\hline 62 & 5.40 & 30 & 5.45 & 22 \\
\hline 63 & 4.26 & 77 & 2.56 & 72 \\
\hline 65 & 5.29 & 33 & 5.32 & 28 \\
\hline 67 & 5.24 & 37 & 2.53 & 73 \\
\hline 69 & 5.69 & 16 & 2.51 & 74 \\
\hline 70 & 5.90 & 6 & 3.61 & 61 \\
\hline 71 & 5.29 & 33 & 3.02 & 65 \\
\hline 72 & 4.88 & 57 & 2.71 & 68 \\
\hline 76 & 5.45 & 27 & 4.73 & 47 \\
\hline 77 & 4.86 & 59 & 4.83 & 43 \\
\hline 78 & 4.62 & 71 & 3.50 & 63 \\
\hline 79 & 4.38 & 76 & 4.69 & 51 \\
\hline 80 & 5.70 & 15 & 1.92 & 77 \\
\hline 81 & 5.24 & 37 & 5.16 & 32 \\
\hline 82 & 4.85 & 60 & 5.03 & 39 \\
\hline 83 & 4.62 & 71 & 5.05 & 38 \\
\hline 85 & 4.88 & 57 & 4.79 & 45 \\
\hline 88 & 5.93 & 3 & 5.90 & 10 \\
\hline 90 & 5.09 & 46 & 5.07 & 35 \\
\hline 91 & 4.07 & 79 & 4.40 & 58 \\
\hline 92 & 6.17 & 1 & 1.68 & 79 \\
\hline 93 & 5.76 & 12 & 2.61 & 71 \\
\hline 95 & 5.49 & 25 & 1.95 & 76 \\
\hline 96 & 4.55 & 73 & 5.52 & 21 \\
\hline 97 & 5.56 & 18 & 5.33 & 27 \\
\hline 99 & 5.26 & 36 & 5.07 & 35 \\
\hline 100 & 5.33 & 31 & 6.29 & 5 \\
\hline 103 & 4.73 & 65 & 4.73 & 47 \\
\hline 104 & 5.27 & 35 & 3.17 & 64 \\
\hline 106 & 5.88 & 8 & 1.74 & 78 \\
\hline
\end{tabular}


Table 1, continued

\section{Rank Order of Mean Impact and Desirability Ratings of Events 2001-2010 Time Frame, continued}

\begin{tabular}{|c|c|c|c|c|}
\hline $\begin{array}{c}\text { Time Frame \& } \\
\text { Event Number }\end{array}$ & $\overline{\mathrm{X}}_{\mathrm{I}}$ & Rank & $\overline{\mathrm{X}}_{\mathrm{D}}$ & Rank \\
\hline 110 & 5.07 & 47 & 5.07 & 35 \\
111 & 5.44 & 28 & 6.33 & 2 \\
112 & 5.07 & 49 & 5.59 & 18 \\
113 & 5.52 & 23 & 5.39 & 24 \\
115 & 5.13 & 41 & 5.36 & 25 \\
117 & 4.63 & 70 & 5.26 & 29 \\
118 & 5.83 & 9 & 6.33 & 2 \\
119 & 5.23 & 39 & 5.85 & 12 \\
123 & 5.81 & 11 & 1.57 & 80 \\
124 & 3.80 & 80 & 2.66 & 69 \\
125 & 4.71 & 66 & 2.46 & 75 \\
127 & 5.93 & 3 & 6.74 & 1 \\
130 & 4.22 & 78 & 3.56 & 62 \\
132 & 4.65 & 69 & 4.88 & 42 \\
& & & & \\
\hline
\end{tabular}


Table 2

Rank Order of Mean Impact and Desirability Ratings of Events 2011-2020 Time Frame

\begin{tabular}{|c|c|c|c|c|}
\hline $\begin{array}{l}\text { Time Frame \& } \\
\text { Event Number }\end{array}$ & $\bar{X}_{I}$ & Rank & $\bar{X}_{D}$ & Rank \\
\hline 4 & 5.93 & 6 & 4.67 & 21 \\
\hline 7 & 5.44 & 17 & 5.00 & 14 \\
\hline 18 & 6.00 & 4 & 6.30 & 3 \\
\hline 20 & 5.69 & 10 & 4.83 & 16 \\
\hline 22 & 5.20 & 26 & 3.00 & 35 \\
\hline 25 & 4.77 & 34 & 4.19 & 25 \\
\hline 26 & 4.80 & 33 & 3.81 & 31 \\
\hline 29 & 5.62 & 13 & 4.76 & 19 \\
\hline 33 & 5.42 & 18 & 3.86 & 29 \\
\hline 43 & 5.19 & 27 & 4.51 & 23 \\
\hline 51 & 4.88 & 31 & 5.25 & 11 \\
\hline 54 & 6.10 & 1 & 6.55 & 2 \\
\hline 56 & 5.23 & 24 & 4.70 & 20 \\
\hline 57 & 5.63 & 12 & 3.15 & 34 \\
\hline 58 & 5.86 & 7 & 5.48 & 8 \\
\hline 60 & 5.84 & 8 & 5.74 & 6 \\
\hline 66 & 5.40 & 19 & 5.15 & 12 \\
\hline 68 & 5.78 & 9 & 1.88 & 37 \\
\hline 74 & 4.11 & 38 & 2.63 & 36 \\
\hline 84 & 5.18 & 28 & 5.93 & 4 \\
\hline 86 & 4.30 & 36 & 4.91 & 15 \\
\hline 87 & 5.56 & 15 & 4.78 & 18 \\
\hline 94 & 5.25 & 23 & 4.08 & 27 \\
\hline 98 & 4.82 & 32 & 3.97 & 28 \\
\hline 102 & 5.23 & 24 & 5.26 & 10 \\
\hline 107 & 5.60 & 14 & 5.05 & 13 \\
\hline 108 & 5.35 & 21 & 5.47 & 9 \\
\hline 109 & 5.14 & 29 & 4.14 & 26 \\
\hline 114 & 5.53 & 16 & 3.85 & 30 \\
\hline 116 & 5.27 & 22 & 4.57 & 22 \\
\hline 121 & 5.36 & 20 & 4.82 & 17 \\
\hline 122 & 5.69 & 10 & 5.78 & 5 \\
\hline 126 & 6.10 & 1 & 6.75 & 1 \\
\hline 128 & 5.97 & 5 & 5.56 & 7 \\
\hline
\end{tabular}


Table 2, continued

Rank Order of Mean Impact and Desirability Ratings of Events 2011-2020 Time Frame

\begin{tabular}{|c|c|c|c|c|}
\hline $\begin{array}{c}\text { Time Frame \& } \\
\text { Event Number }\end{array}$ & $\overline{\mathrm{X}}_{\mathrm{I}}$ & Rank & $\overline{\mathrm{X}}_{\mathrm{D}}$ & Rank \\
\hline 129 & 6.08 & 3 & 1.28 & 38 \\
131 & 4.28 & 37 & 3.20 & 33 \\
133 & 4.90 & 30 & 4.22 & 24 \\
134 & 4.70 & 35 & 3.79 & 32 \\
& & & & \\
\hline
\end{tabular}

Table 3

Rank Order of Mean Impact and Desirability Ratings of Events After 2020 Time Frame

\begin{tabular}{|c|c|c|c|c|}
\hline $\begin{array}{c}\text { Time Frame \& } \\
\text { Event Number }\end{array}$ & $\overline{\mathrm{X}}_{\mathrm{I}}$ & Rank & $\overline{\mathrm{X}}_{\mathrm{D}}$ & Rank \\
\hline 8 & 5.95 & 1 & 3.45 & 2 \\
28 & 5.10 & 3 & 1.53 & 5 \\
30 & 3.90 & 5 & 3.14 & 4 \\
41 & 4.28 & 4 & 3.23 & 3 \\
89 & 5.62 & 2 & 5.12 & 1 \\
\hline
\end{tabular}


Table 4

Rank Order of Mean Impact and Desirability Ratings of Events Never Time Frame

\begin{tabular}{|c|c|c|c|c|}
\hline $\begin{array}{c}\text { Time Frame \& } \\
\text { Event Number }\end{array}$ & $\overline{\mathrm{X}}_{\mathrm{I}}$ & Rank & $\overline{\mathrm{X}}_{\mathrm{D}}$ & Rank \\
\hline 1 & 3.28 & 11 & 2.20 & 11 \\
2 & 3.51 & 10 & 2.80 & 8 \\
10 & 4.57 & 8 & 3.67 & 5 \\
12 & 6.41 & 1 & 4.31 & 4 \\
27 & 4.76 & 7 & 3.63 & 6 \\
64 & 5.20 & 4 & 5.73 & 1 \\
73 & 4.90 & 6 & 4.44 & 2 \\
75 & 5.50 & 3 & 2.47 & 9 \\
101 & 5.16 & 5 & 4.32 & 10 \\
105 & 5.61 & 2 & 2.42 & 7 \\
120 & 3.72 & 9 & 3.50 & \\
\hline
\end{tabular}




\section{Appendix G}

Vita 


\section{VITA}

CARL H. FRIEBEL, JR.

MARCH, 1999

BUSINESS ADDRESS: Harrison County Board of Education

Post Office Box 1370

Clarksburg, West Virginia 26302-1370

Phone: (304) 624-3304

Fax: (304) 624-3361

E-mail: cfriebel@wvu.edu

HOME ADDRESS: $\quad 204$ Maple Lake

Bridgeport, West Virginia 26330

Phone: (304) 842-2009

BIRTHDATE: $\quad$ January 30,1947

PLACE OF BIRTH: $\quad$ Philadelphia, Pennsylvania

WIFE'S NAME: $\quad$ Rita G. Friebel

CHILDREN: $\quad$ Three sons - Ryan, 26, Ross, 21, and Casey, deceased

EDUCATION:

1996-present West Virginia University, Morgantown, West Virginia, Doctor of Education, Second CEO Cohort Doctoral Program, Educational Leadership Studies

1992-94 West Virginia College of Graduate Studies, Institute, West Virginia. Graduate studies in Education Administration and Curriculum

1974-84 West Virginia University, Morgantown, West Virginia. Master of Arts Degree granted May, 1978

1973-74 Glenville State College, Glenville, West Virginia. Certification studies

1970-71 Trenton State College, Graduate School, Trenton, New Jersey. Certification studies 
$1969-71$

Temple University, Graduate School, Philadelphia, Pennsylvania. Graduate studies in anthropology

1967 University of the Americas, Mexico City, Mexico. Junior Year Abroad

1964-66 \& 1967-68 West Virginia Wesleyan College, Buckhannon, West Virginia. Bachelor of Arts Degree

EMPLOYMENT HISTORY:

1986 - Present $\quad$ Administrative Assistant to the Superintendent, Planning, Research \& Evaluation, Harrison County Board of Education, Clarksburg, West Virginia 26301

1981 - 86 Administrative Assistant to the Superintendent, Ancillary Services, Harrison County Board of Education, Clarksburg, West Virginia 26301

1979 - $81 \quad$ Assistant Director, Special Education Department, Harrison County Board of Education, Clarksburg, West Virginia 26301

1972 - $79 \quad$ Teacher, special education, Harrison County Board of Education, Clarksburg, West Virginia 26301. Teacher at Central Junior High School (2 years), Adamston Elementary School (Secondary program, 3 years), and Bridgeport High School (2 years)

1968 - 72 Teacher, special education, industrial arts instructor, Pre-vocational Coordinator, Ashbourne School, Elkins Park, Pennsylvania 19117

PROFESSIONAL ACTIVITIES:

Chairman, West Virginia State Advisory Council on the Education Block Grant

Participant, County Accreditation Review Teams for West Virginia Department of Education (Berkeley, Brooke, Clay, Fayette, Greenbrier, Jackson, Jefferson, Kanawha, Lincoln, McDowell, Mercer, Mineral and Ritchie counties)

Participant, Leading Groups Seminar, McNellis Creative Planning Institute, CNG (Consolidated Natural Gas) Transmission Corporation, Clarksburg, West Virginia, August, 1993

Past President, Harrison County Chapter, Council for Exceptional Children 
Author of grant funded by the West Virginia Juvenile Justice Commission for adolescent alternative education, 1984

Consultive services on Comprehensive Educational Facilities Plans, Strategic Planning, and Unified School Improvement Planning

Member, Harrison County Schools/Jostens Learning Corporation National Partnership in Education Planning Committee

Member, Harrison County Schools/WVHTC (West Virginia High Tech Consortium)

Technology Plan Study Committee/Task Force

Past Chair, Harrison County Schools Technology Committee

\section{HONORS:}

Phi Delta Kappa, Professional Fraternity in Education

Kappa Delta Pi, An Honor Society in Education

Gubernatorial appointment to the West Virginia State Advisory Council on the Education Block Grant

Certificate of Achievement, National Association for Retarded Citizens, On-The-Job Training Project

\section{PROFESSIONAL AFFILIATIONS:}

West Virginia Association of School Administrators

Harrison County Reading Council

West Virginia Reading Association 